\title{
The Analysis of the International Legal Water Regime of the Mekong River Basin
}

\author{
Dissertation \\ zur Erlangung des Doktorgrades \\ der Juristischen Fakultät \\ der Georg-August-Universität zu Göttingen \\ vorgelegt \\ von \\ Yi Fu \\ aus \\ Hunan, China
}

Göttingen 2016 


\section{Abstract}

On 27 August 2014, the world famous 1997 Convention on the Law of the Nonnavigational Uses of International Watercourses (the 1997 UNWC) entered into force. This event once again made international water law become a hot topic in the academic field, especially that of international public law. Moreover, according to the rapid development of the economy in Southeast Asia and also China, the Mekong River basin is gaining more and more attention in many respects. This dissertation focuses on international water law as it specifically applies to the Mekong River basin. The research presented herein analyzes the Mekong water regime firstly; secondly, it identifies the problems with this regime by means of assessment and comparison; lastly, it designated ways in which the regime could be improved upon.

The author presents an in-depth analysis of the international legal water regime of the Mekong River basin and proposes an assessment thereof. She also uses another famous and mature international water regime, namely the Rhine water regime, to make a functional comparison focusing merely on the realistic functions of these two regimes. This comparison is an integral point of this dissertation, and draws a clear picture for people to understand what an international water regime can do in reality. At the same time, this comparison provides a series of inspirations for considerations on how to improve the Mekong water regime. In order to lay a more effective foundation for suggestions on how to achieve this objective, the author also uses the 1997 UNWC, which entered into force in 2014, as a model for the improvement of the only specific legally binding basis of this regime, namely the 1995 Mekong Agreement. Based on the analysis, assessment, and comparisons just described, the author distinguishes the optimal direction for efforts to improve the Mekong water regime. In the last chapter, the author expresses that not only the legal basis but also the regime's institution should be improved; furthermore, the relationships with the donors, the NGOs, the public and also the upstream countries, especially China, must also be taken into account for its future development.

The objective of the dissertation is to give its readers an explicit understanding of the Mekong River basin's international legal water regime and know its characters and drawbacks. Two of the comparisons laid out in this dissertation are also two crucial new points for readers to draw inspiration from. The improvement suggested provides 
several meaningful ways of achieving the future development of the Mekong water regime, as well as a good basis for guiding the actions of the Mekong River Commission and also for regional cooperation and communication.

\section{Keywords}

International Water Law; Mekong Water Legal Regime; Comparison; Improvement 


\section{Table of Contents}

Abstract.............................................................................................................................................. I

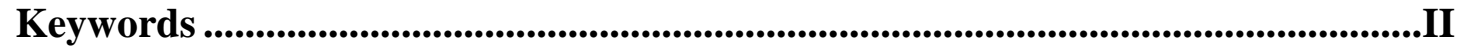

Table of Contents ............................................................................................................ III

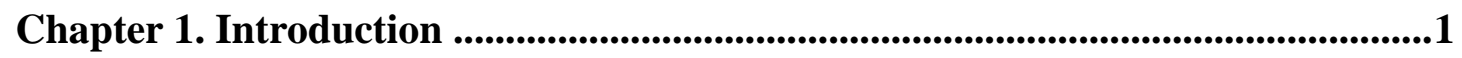

1.1. Research Question and Dissertation Structure ….............................................................. 1

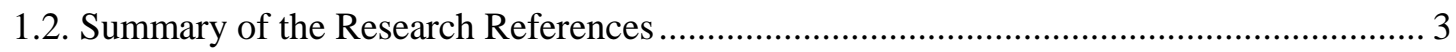

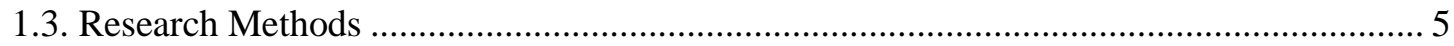

Chapter 2. Introduction to the International Legal Water Regime of the Mekong

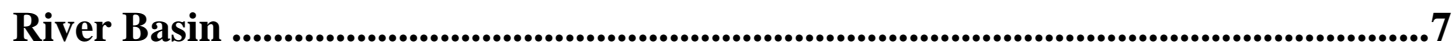

2.1. Context of the Present International Legal Water Regime of the Mekong River Basin .... 7

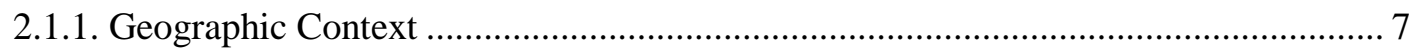

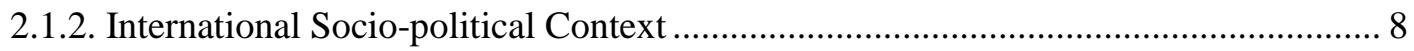

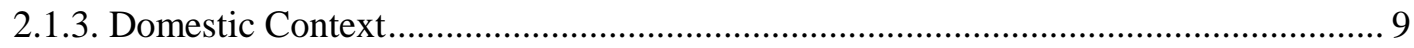

2.2. Legal basis of the International Legal Water Regime in the Mekong River Basin .......... 11

2.2.1. International Water and Water-related Law.................................................................. 11

2.2.2. The 1995 Mekong Agreement …......................................................................... 17

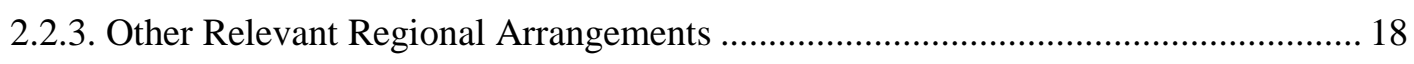

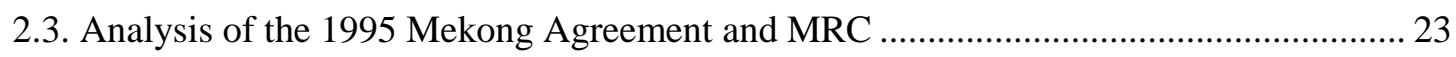

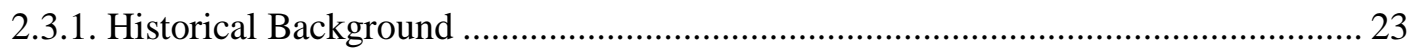

2.3.2. Introduction to the 1995 Mekong Agreement and the MRC.................................... 33

2.3.3. The Complex Relationship within The Mekong Water Regime................................ 55

2.3.4. Assessment of the 1995 Mekong Agreement and the MRC ...................................... 61

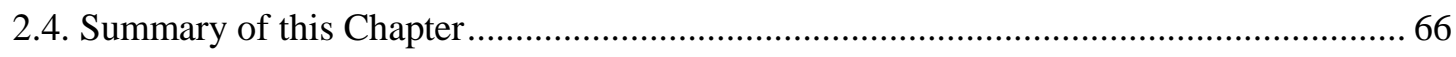

Chapter 3. Functional Comparison of the International Legal Water Regimes in the Mekong River Basin and the Rhine River Basin .............................................68

3.1. Functions of the International Legal Water Regime in the Mekong River Basin ............ 68

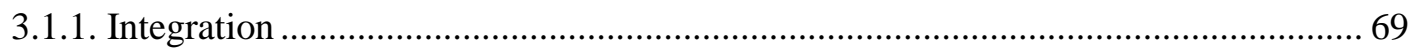

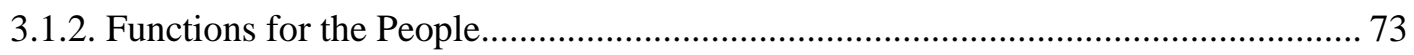

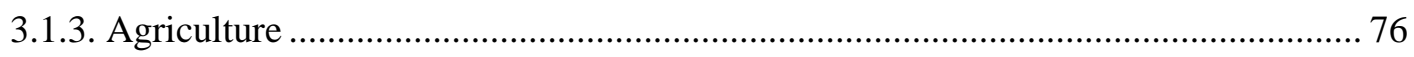

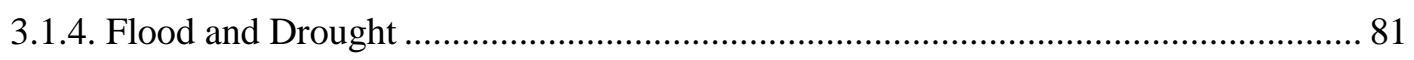

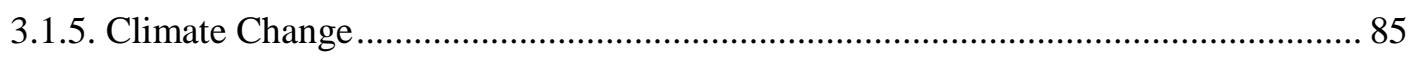

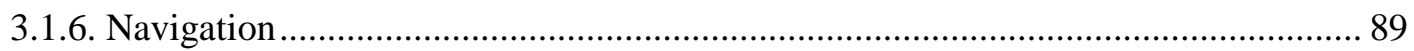

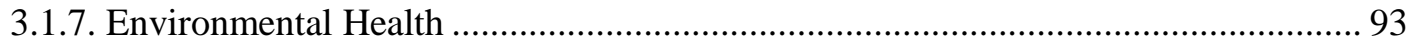

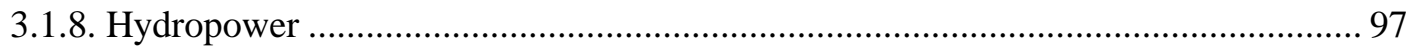

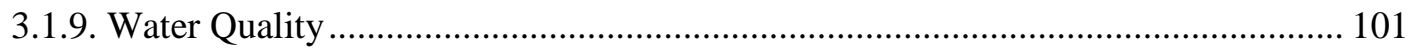


3.1.11. Conclusion of the Mekong Water Regime's Function......................................... 106

3.2. Comparison with the Rhine River Basin ......................................................................... 107

3.2.1. Introduction to the International Legal Water Regime in the Rhine River Basin ... 107

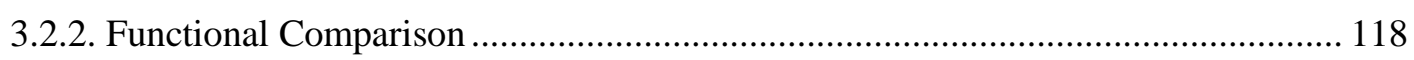

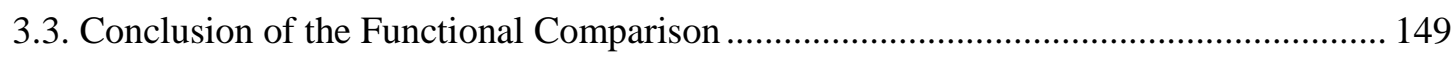

Chapter 4. Improvement of the International Legal Water Regime of the

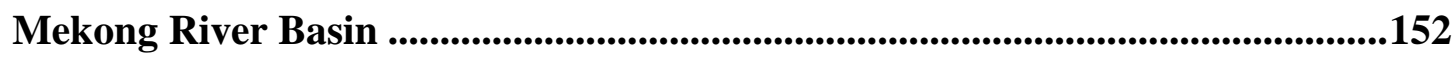

4.1. The 1997 UNWC as an Important Basis for the Improvements................................... 152

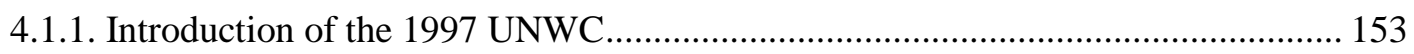

4.1.2. Reasons to Choose the 1997 UNWC as a Basis for the Improvement.................... 162

4.1.3. Points Requiring Improvement based on the Comparison of the 1997 UNWC with

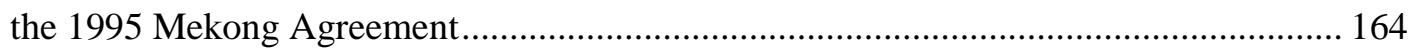

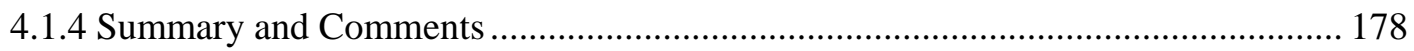

4.2. Ways to Improve the International Legal Water Regime of the Mekong River Basin .. 179

4.2.1. Improvements of The Regime's Legal Basis .......................................................... 181

4.2.2. Improvements of the Mekong River Commission ................................................... 194

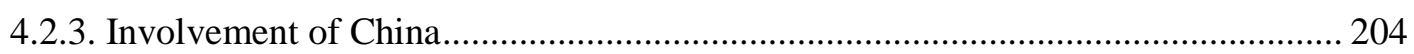

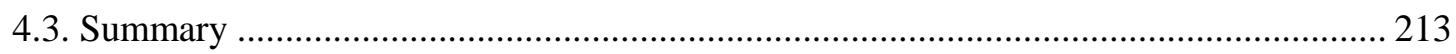

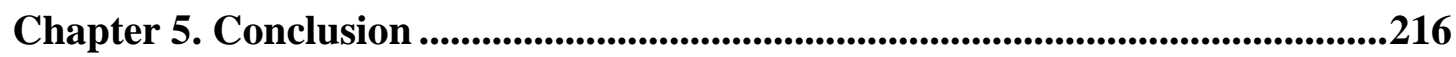

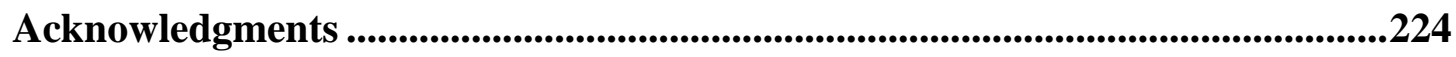

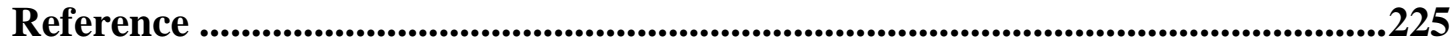

Legally and Non-legally Binding Documents .................................................................... 225

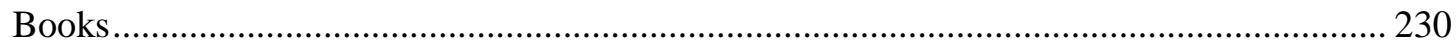

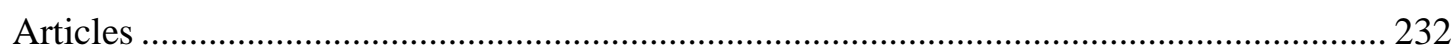

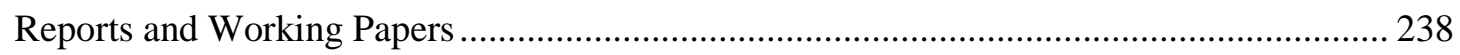

Official Websites of Relative International Organizations.................................................. 241

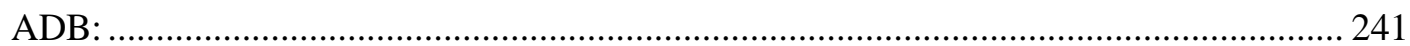

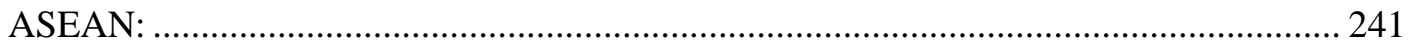

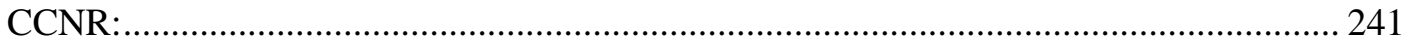

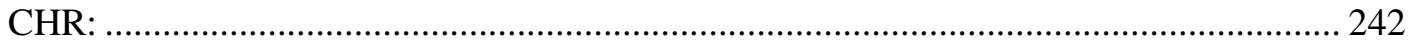

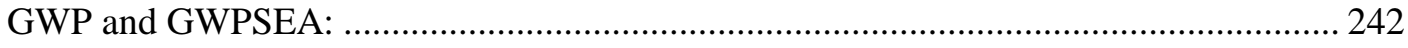

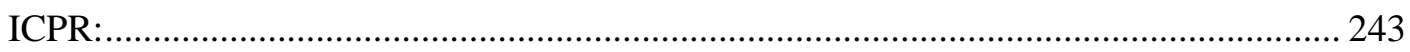

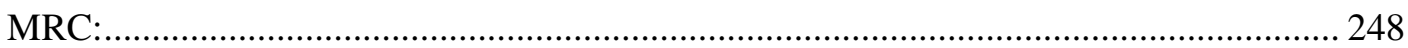

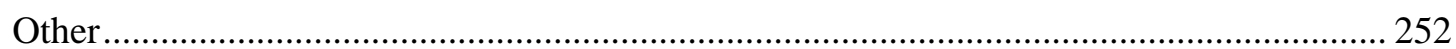

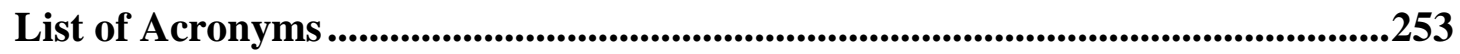




\section{Chapter 1. Introduction}

Nowadays, water resources as a vital element for the sustainable development of the world has been discussed in various academic disciplines. As a component part of the water resources, the transboundary water resources, which are closely related to the international watercourse, could influence the international relations, politics, and also economic development. The international law, especially the international water law, as an important tool for the international community also notices the importance of this phenomenon. The author, as an international law researcher, is interested in sorting out the basic knowledge of contemporary international water law and discovering some new development in this field. And therefore, this dissertation starts itself from two essential points: the international law and transboundary water resources in an international watercourse, and tries to explain how the international law serves the management and protection of the transboundary water resources in a international watercourse by using a case study, namely the analysis of the international legal water regime of the Mekong River basin (which is also called as Mekong water regime). It presents some new angles for this topic, which could cover gaps of existing related researches and bring relevant inspirations for future progress of the Mekong water regime.

\subsection{Research Question and Dissertation Structure}

In accordance with the rapid development of the Mekong River basin as well as the change of the legal status of the 1997 UN Watercourse Convention, the connection between international water law and the Mekong River basin has once again come into focus in academic circles. Although the development of international water law has always played a vital part in international law, at the same time, focusing on a special region and researching a specific international watercourse can be more explicit and meaningful for the development of the international water law at the macro level. It is based on these considerations that the author has chosen the international legal water regime of the Mekong River basin as the research subject of this dissertation and wants to draw a comprehensive map for all reader to guide their trip to the Mekong water regime. 
According to the Oxford English Dictionary, the word "regime" means a method or system of rule, governance, or control; a system of organization; a way of doing things, esp. one having widespread influence or prevalence. ${ }^{1}$ The "international legal water regime" referred to in this dissertation thus denotes a system based on the international law of managing the water resources and water resources-related affairs along an international watercourse.

Defining what the Mekong water regime is and how it works is a crucial foundation for understanding it better and conducting further research on it. The author has also decided to make two comparisons to find out what kind of drawbacks the Mekong water regime has. The findings from these comparisons in turn define the direction for improvements on this regime. These improvements can be meaningful not only for the regime itself, but also for Mekong regional sustainable development, international cooperation, as well as better communication in the future. In summary, the research question can be posed as such: characterize the Mekong water regime, analyze the points that need to be improved, and then find the best methods of realizing these improvements. Given that this research question focuses on the international legal regime and its concentration on the connection between the international water law and the Mekong River basin, the relevant legal regime at the domestic level will not be discussed in detail in this dissertation.

In addition to providing readers with an explicit and comprehensive map of the international legal water regime of the Mekong River basin, this dissertation presents a comparison between the functions of the Mekong water regime and the Rhine water regime that highlights some special characteristics of the former. This description also educates readers on how an international legal water regime works through its institution in reality. The last chapter supplies several suggestions on how to improve the Mekong water regime that can be used to guide future actions. Not only does this dissertation give meaningful consideration to the impact of the UNWC, which became effective in 2014 , but the means by which an effective international water law legal framework influences a specific international watercourse has also been illustrated clearly. Last but not least, the discussion of the Chinese involvement in the Mekong water regime can promote the relationship between China and other

\footnotetext{
${ }^{1}$ Oxford English Dictionary, 'Regime'

<http://www.oed.com/view/Entry/161266?redirectedFrom=regime\#eid> accessed 02 October 2016.
} 
downstream countries, which is highly beneficial for regional development with regard to economical, environmental as well as social aspects.

This dissertation uses a three-steps model to describe the whole story. The first step is to describe the Mekong water regime in detail and provides the foundation for the entire dissertation. The subsequent second step is the functional comparison between the Mekong water regime and the Rhine water regime. This functional comparison focuses only on the functions performed by these two regimes, which accordingly allows us to compare these two regimes at the level of implementation. The enlightenment gained by drawing this comparison brings inspiration for improvement of the Mekong water regime. The last but not least, the third step of this dissertation has been dedicated to finding ways to improve the Mekong water regime. The improvement of the legal basis and the institution, involvement of China have all been illustrated here.

\subsection{Summary of the Research References}

Although there are a few specific works that have proved useful for conducting research on the international legal water regime of the Mekong River basin, their content is, unfortunately, not comprehensive; most describe only one aspect of the international legal water regime, respectively. For instance, some articles focus on the legal basis of the regime and ignore the effects of the institution; conversely, other articles focus on the institutional work of the regime but do not discuss the legal basis in enough depth. Moreover, there are many research articles that focus on the national legal water regime of the Mekong River basin, analyzing the national legal water regime in each riparian country. But research at the level of international legal water regimes is also necessary for the liquidity of the international watercourse. Therefore, a comprehensive and specifically targeted dissertation on the research on international legal water regime of the Mekong River basin is necessary and meaningful for regional cooperation and development in the future.

Another point that must be expressed is that most of the literature related to the Mekong water regime was published before 2014. Therefore, the entry into force of the famous 1997 UN Watercourse Convention had not been taken into consideration by these works. Although some of these references did indeed mention the 1997 UNWC, the related analysis remained theoretical due to the uncertain legal status of the Convention at the time they were published. Now that the 1997 UNWC has 
entered into force, its position in the field of international public law has also been enhanced. Furthermore, Vietnam, as the riparian country furthest downstream, is the $35^{\text {th }}$ country to ratify and enforce the Convention. The Vietnamese ratification connects the Mekong water regime with the 1997 UNWC. For this crucial reason, any discussion of the Mekong water regime must also consider the entry into force of the 1997 UNWC.

As for the comparison section, the related literature is rather scant. There is no other work that compares the functions of the Mekong water regime and the Rhine water regime. The only article that compares the 1995 Mekong agreement with the 1997 UNWC is neither detailed nor comprehensive enough. It expresses the difference between these two legal instruments, but does not analyze the reasons behind these differences and give a reasonable summary. In this dissertation, the author attempts to make a functional comparison between the Mekong water regime and the Rhine water regime that focuses on the functions of these two regimes. This functional comparison presents a new direction of comparison research, and also gives readers a more explicit picture of what an international legal water regime can do for the development of the international watercourse in reality.

Furthermore, China, as the most important upstream country, has not been considered in enough depth by the literature related to the Mekong water regime. Even though nearly all of these sources mention China and know that it is a vital element for the Mekong water regime, the related discussion is neither comprehensive nor sufficient. The author would like to fill this gap by discussing the relationship between the Mekong water regime and the involvement of China in this water regime.

Besides the literature mentioned above, some works cited in this dissertation are mainly from the official website of the Mekong River Commission, Rhine River Commission and other related international organizations. Books on basic theory of international public law, international environmental law and international water law have also been cited frequently.

Although the existing variety of sources establishes a good foundation for further research in this dissertation, there are still some aspects they leave uncovered. Therefore, there is also space for the author to get information from non-specific fields, to organize all this information for the novel points in this dissertation and fill the gaps not mentioned in other sources. 


\subsection{Research Methods}

In this dissertation, the main research method utilized is the comparative method. To this day, there are still disputes on the concept of comparative law at the academic level. Some scholars think that it is purely a method of law; others think that it is already a science. ${ }^{2}$ In fact, a comparative work has several functions that can fulfill various purposes in the academic field. Firstly, the comparative method can improve academic discipline. ${ }^{3}$ Secondly, it can provide significant materials to legislation and law reform. ${ }^{4}$ Thirdly, it also offers supplements and support to judicial decisions. ${ }^{5}$ Moreover, it can strengthen people's understanding of legal contents. ${ }^{6}$ Furthermore, it is a vital basis for the "systematic unification and harmonization of law". ${ }^{7}$ Last but not least, it is also an important foundation for the implementation of the international law. ${ }^{8}$

Nearly half of the content presented in this thesis focuses on comparison. One is the functional comparison of the Mekong water regime with the Rhine water regime. This comparison focuses only on the functions of these two regimes. It compares these two regimes in a non-traditional way, not comparing their legal bases or institutional organizations. A functional comparison such as this offers a new angle to see the differences between two distinct regimes of international watercourses. Additionally, this functional comparison is more close to the aspects of implementation. Hence, the research results can provide more explicit suggestions for the future development of the Mekong water regime, especially as regards its institutional actions. The second comparison in this dissertation is the comparison between the 1995 Mekong Agreement and the 1997 UN Watercourse Convention. This comparison is a significant basis for the improvement of the Mekong water regime, especially for

\footnotetext{
${ }^{2}$ Peter de Cruz, 'Comparative Law, Functions and Methods', Max Planck Encyclopedia of Public International Law (Fall edn 2009), Paragraph 1

<http://opil.ouplaw.com/view/10.1093/law:epil/9780199231690/law-9780199231690e1018?rskey=EQWcAt\&result=1\&prd=EPIL> accessed 2 October 2016.

${ }^{3}$ Cruz (n 2) Paragraph 21.

${ }^{4}$ Ibid.

${ }^{5}$ Ibid.

${ }^{6}$ Ibid.

${ }^{7}$ Ibid.

${ }^{8}$ Ibid.
} 
improvement of regime's legal basis. The reasons for choosing the 1997 UNWC are its entry into force and its ratification by Vietnam. These reasons deepen the connection of the 1997 UNWC with the Mekong water regime. The comparison itself is not only to present all differences between these two legal instruments. The reasons behind all differences have also been explained in this comparison. In a word, neither of these two comparisons is a simple and mechanical comparison of two subjects; they also include in-depth analyses and provide a meaningful basis for the improvement of the Mekong water.

Except the comparative method, the other methods of legal research have also been used in this dissertation. Historical method has been used for explaining the context of this dissertation, and the evolution of the Mekong water regime. Translating method has been used for analyzing the relationship between China and the Mekong water regime and Chinese involvement into the Mekong water regime, due to many references are in Chinese. The method to explain the international legal instruments has also been used for comparing two legal instruments for international watercourse. To summary, this dissertation is a legal research of the Mekong water regime, and aims to find the ways to its improvements. The basis for this research is chiefly comparison works in aspects of legal basis and implementation. It is a comprehensive and detailed road guide for researching the Mekong water regime. The readers can gain plenty of information from this road guide, which is a quite meaningful basis for readers' own related exploration in this field. The author hopes that this dissertation could make contributions to other related research and the improvement of the efficiency and environmental sustainability of the entire Mekong water regime in the long run. 


\section{Chapter 2. Introduction to the International Legal Water Regime of}

\section{the Mekong River Basin}

The international legal water regime of the Mekong River basin is created within a very complicated context. Numerous elements have affected the evolution of this regime. For a regime of an international watercourse, not only the geographic context could bring influences but also the socio-political and domestic context could make contributions to its development. Due to this complicated context, the legal basis for this regime also becomes multi-level and consists of several various elements from the sources of international law. However, the core in its legal basis is the 1995 Mekong Agreement that is the only legally binding and specific instrument for the water resources management and protection in the Mekong River basin. It includes the provisions for the substantive affairs, and also the provisions for procedural and institutional affairs that are related to the Mekong River Commission. In following sections, a comprehensive and systematic map for introduction to this regime will be illustrated.

\subsection{Context of the Present International Legal Water Regime of the Mekong River Basin}

\subsubsection{Geographic Context}

The Mekong River is the twelfth longest river in the world $(4173 \mathrm{~km})$, and its volume of flow ranks tenth (475 BCM/year) among the world's rivers. ${ }^{9}$ The area of the Mekong River Basin covers 795,000 $\mathrm{km}^{2}$ and includes six riparian countries. ${ }^{10}$ Its headwater originates in the Qinghai Province of China and flows through the Yunnan Province of China into Southeast Asia. In China, it is called the Lancang River. The Mekong River forms the boundary between Laos and Myanmar and also separates Thailand from Laos. It passes through the heart of Cambodia and then empties out

\footnotetext{
${ }^{9}$ George E. Radosevich, Douglas C. Olson, 'Existing and Emerging Basin Arrangements in Asia: Mekong River Commission Case Study’ (1999) The World Bank, Third Workshop on River Basin Institution Development, 4 < http://siteresources.worldbank.org/INTWRD/918599-

1112615943168/20431963/MekgongRiverComCaseStudy.pdf > accessed 25 October 2016; Matti Kummu, Olli Varis, 'Sediment-related impacts due to upstream reservoir trapping, the Lower Mekong River' (2007) 85 Geomorphology 275, 277.

${ }^{10}$ Ibid.
} 
from Vietnam into the South China Sea through the Mekong Delta. ${ }^{11}$ The Lower Mekong River Basin (LMRB) consists of geographic areas belonging to four member states on the Mekong Committee and Interim Mekong Committee, and the present Mekong River Commission. ${ }^{12}$ The Mekong water regime is an international water governance system for water resource management and development in the LMRB. Its Member states include Thailand, Vietnam, Laos and Cambodia. The two upper Mekong River Basin states, China and Myanmar, are not members of the Mekong water regime, but already became official "dialogue partners" in $1996 .{ }^{13}$

The Mekong water Regime has existed since 1957, while the present Mekong River Commission (MRC) was established on the basis of the 1995 Mekong Agreement with the main function of sustainable development of the Mekong River basin. The Mekong Agreement governs the LMRB that drains parts of Vietnam, nearly one-third of Thailand, and most of Laos and Cambodia. The LMRB consists of two main tributary systems: left-bank tributary systems that contribute to wet-season flow, and right-bank tributary systems that drain low relief areas with lower rainfall. The Tonlé Sap is a natural storage reservoir in the wet season that releases its flows to the benefit of the Mekong Delta in the dry season. ${ }^{14}$

The LMRB experiences a tropical monsoon climate, which causes extreme seasonal changes in precipitation. ${ }^{15}$ During the wet season, from July to October, the flow of the Mekong becomes very high and also brings floods. By the dry season, from January to May, the LMRB only has little rainfall and low flow rates at the most downstream location. ${ }^{16}$

\subsubsection{International Socio-political Context}

The international social and political context of the 1990s impacted and changed the relations between countries in Southeast Asia. A Mekong basin-wide agreement

\footnotetext{
${ }^{11}$ Ben Boer, Philip Hirsch, Fleur Johns, Ben Saul and Natalia Scurrah, The Mekong: A Socio-Legal Approach to River Basin Development (New York, 1st, Routledge, 2016) 6-7.

${ }^{12}$ Greg Browder and Leonard Ortolano, 'The Evolution of an International Water Resources Management Regime in the Mekong River Basin’ (2000) 40 Nat. Resources J 499, 500.

${ }^{13}$ Kayo Onishi, 'Interstate negotiation mechanisms for cooperation in the Mekong river basin' (2011) 32 Water International 524, 532.

${ }^{14}$ Browder, Ortolano (n 12) 503-504.

${ }^{15}$ Browder, Ortolano (n 12) 501.

${ }^{16}$ Ibid.
} 
would bring many benefits to the riparian countries that hold distinct views on this regional regime and know that their demands can only be reached through the regional cooperation. ${ }^{17}$ These social and political changes can be summed up as follows:

The Cold War ended in the early 1990s, which opened a new era for the world. After decades of ideological discord and war in the Mekong region, Thailand and Vietnam, the two countries belonged originally to two different camps, did not want disputes over water allocation that might affect regional cooperation and solidarity. ${ }^{18}$

The exploitation of water resources in China could significantly enhance the flows of the Mekong in the dry season. Water allocation in the dry season is a vital issue for LMRB countries, and has become more important based on the fact that Chinese dams increased the dry season flows of the Mekong River. Even though there was no data on or general knowledge of the impacts of Chinese dams at that time, these dams still became a catalyst for negotiations on how to allocate the increased dry season water. $^{19}$

A lot of international development agencies have been willing to supply financial and technical assistance to the LMRB countries. This external support has promoted cooperation between the LMRB countries and therefore enhanced the effectiveness of the MRC with respect to managing and developing their common water sources. Cambodia and Laos, the two poorest countries in LMRB, would particularly benefit from such assistance. ${ }^{20}$

\subsubsection{Domestic Context}

In the pre-Mekong Agreement stage, all four LMRB countries had to deal with the inconsistent seasonal water flows of the Mekong River. They all wanted to solve this problem in line with the objectives of the Mekong water regime and simultaneously continue considering the domestic interests. The domestic interests of the member states can be delineated as described in the following subchapters.

\footnotetext{
${ }^{17}$ Browder, Ortolano (n 12) 518.

${ }^{18}$ Richard Kyle Paisly, Patrick Weiler and Taylor Henshaw, 'Transboundary Waters Governance through the Prism of the Mekong River Basin’ Janice Gray, Cameron Holley, Rosemary Rayfuse (eds), Trans-jurisdictional Water Law and Governance (UK, 1st edn, Routledge, 2016) 45.

${ }^{19}$ Browder, Ortolano (n 12) 513-14.

${ }^{20}$ Browder, Ortolano (n 12) 518.
} 


\subsubsection{Vietnam}

The initial task of Vietnam was to conserve the Mekong Delta, which is its agricultural center and is also famous for its rice farming. In order to support the rice farming industry, considerable amounts of water from the Mekong River have been used for irrigation of rice farms. ${ }^{21}$ However, problems inevitably arise in the dry season, when the Mekong River's flow becomes lower. The minimum flows of the Mekong River are not only used for agricultural irrigation but also to prevent salinity intrusion from seawater. ${ }^{22}$ According to these facts, Vietnam was in favor of establishing dams along the Mekong mainstream, given that dams could control these flows and decrease the influence of inconsistent seasonal changes in flows. ${ }^{23}$

\subsubsection{Thailand}

Thailand did not want any projects that would make Thai people's lives more difficult, subject to prior agreement through the Mekong Committee. In the early 1990s Thailand could hardly use the natural water from the Mekong River in the dry season and wanted to divert water from the mainstream to support the irrigation of the poor regions in North-Eastern Thailand. ${ }^{24}$

\subsubsection{Laos}

Laos wanted to improve the navigable function of the Mekong River, which is vital for Laos because of its location, population distribution and undeveloped land routes. The hydroelectric potential and related revenue could also promote Laos' development. ${ }^{25}$

\subsubsection{Cambodia}

The conservation of the Tonlé Sap (The Great Lake) was at the core of Cambodia's water priorities. The Tonlé Sap Lake and River derive from a tributary of the Mekong mainstream, which could be affected by seasonally changed flow volumes of the mainstream. ${ }^{26}$ Cambodia concluded that upstream water projects such as dams in

\footnotetext{
${ }^{21}$ Greg Browder, 'An Analysis of the Negotiations for the 1995 Mekong Agreement' (2000) 5 International Negotiation 237, 241-42.

22 Ibid.

${ }^{23}$ Browder (n 21) 242.

${ }^{24}$ Browder, Ortolano (n 12) 512.

${ }^{25}$ Browder (n 21) 242.

${ }^{26}$ Browder, Ortolano (n 12) 519.
} 
China, Laos and Thailand would damage the ecosystem of the Tonle Sap, which "represents one of the largest wetland biodiversity reservoirs in Southeast Asia and is among the most productive fishing grounds in the world." 27

\subsection{Legal basis of the International Legal Water Regime in the Mekong River Basin}

\subsubsection{International Water and Water-related Law}

There are numerous elements that international law has concerned itself with. As a core element for harmony of ecosystems, water resources have always stood in the center of the stage of environmental issues. This fact has even caused a series of serious conflicts between communities or states in some arid areas. Based on eager requirements for better management and solutions for water resource conservation, many water-related instruments have come into play at international and regional levels.

\subsubsection{Introduction of the Sources from the International Water Law}

Industrialization has been a vital factor for more intensive utilization of water resources, which has also caused international discussions over trans-boundary fresh water. According to the states' practices, all states agree that "only riparian states have the legal right, absent agreement, to utilize the water resource of a river, lake or other surface source". ${ }^{28}$ The uppermost riparian state claims "absolute territorial sovereignty", which means it has the right to deal with the water as it sees fit and can ignore the resulting effects on other riparian states. On the other hand, downstream states claim a right to the "absolute integrity of the watercourse", which requires upper riparian states not to do anything that affects the quantity and quality of the water downstream. Neither one of these claims will necessarily prevail, and the usual resolution is the concept of "restricted sovereignty", which has been named as a principle of equitable utilization. ${ }^{29}$ This resolution means that all riparian states have a right to use the water resources from the common stream and must also maintain their utilization to not interfere with utilization in other riparian states. This resolution has

\footnotetext{
${ }^{27}$ Paisly, Weiler, Henshaw (n 18) 46.

${ }^{28}$ Joseph W. Dellapenna, 'The Customary International Law of Trans-boundary Fresh Waters' (2001)

1 Int. J. Global Environmental Issues 264, 269.

${ }^{29}$ Dellapenna (n 28) 270.
} 
also gained customary law status and become a principle of international water law utilized in many treaties related to shared water resources. ${ }^{30}$ Based on this principle, other international laws dealing with more concrete issues regarding shared water resources have been established as well.

\subsection{The Helsinki Rules and the ILA's Contribution}

The International Law Association (ILA) passed the Helsinki Rules on the Uses of the Waters of International Rivers in $1966 .{ }^{31}$ The Helsinki Rules were the first attempt to codify the entire law of international watercourses and "heavily influenced state practices and other international associations in examining the law of internationally shared fresh waters." ${ }^{32}$ These rules treat international drainage basins as an individual unit, and explicitly include all tributaries by using the concept of "drainage basin". The principle of "equitable utilization", which is connected to the rule of restricted sovereignty, has been stipulated in the contents of the Helsinki Rules. ${ }^{33}$

The ILA has continued to draft rules regarding water resources that were not included in the Helsinki Rules, which include flood control, pollution prevention, navigation, groundwater, cross-media pollution and so forth. ${ }^{34}$ Additionally, the ILA has also developed other principles for governing the shared water resources, that "no riparian state shall cause 'substantial damage' to the environment or the natural conditions of the waters beyond the limits of the nation's jurisdiction." ${ }^{35}$ The relationship between the "no harm" rule and the "equitable utilization" rule was controversial at that time and also produced confusion in this field.

\subsection{The $1997 \mathrm{UNWC}^{36}$}

The 1997 UNWC was drafted by the ILC and adopted by the UN General Assembly on 21 May 1997; by 17 August 2014, the treaty had been ratified by 36 states and entered into force. This Convention is a framework for utilization, sustainable

\footnotetext{
${ }^{30}$ Ibid.

${ }^{31}$ Dellapenna (n 28) 273-74.

32 Ibid.

${ }^{33}$ Ibid.

${ }^{34}$ Salman M. A. Salman, 'The Helsinki Rules, the UN Watercourses Convention and the Berlin Rules: Perspectives on International Water Law' (2007) 23 Water Resources Development 625, 629.

${ }^{35}$ Dellapenna (n 28) 274.

${ }^{36}$ Salman (n 34) 631-34.
} 
development, conservation, management and protection of international watercourses. It includes a number of procedural provisions and several substantive provisions, and allows the riparian states to decide the details connected to specific characteristics of the watercourse independently. It is a recognized authoritative codification of customary international water law. ${ }^{37}$

The Convention consists of 37 articles divided into seven parts. It also includes an additional Annex on arbitration. The Convention addresses the definition of "the term 'Watercourse'; watercourse agreements; equitable and reasonable utilization; obligation not to cause harm; planned measures; protection, preservation and management; and dispute settlement." 38 The further details of the Convention will be discussed in the fourth chapter, which makes a comparison between the 1995 Mekong Agreement and the 1997 UNWC.

\subsection{The Berlin Rules ${ }^{39}$}

The Berlin Rules on Water Resources were discussed and approved during the Seventy-first ILA Conference in August 2004. The Berlin Rules are quite comprehensive, consisting of 73 articles and divided into 14 chapters. It covers a variety of issues on water resources that were not included in the Helsinki Rules or the UN Watercourse Convention.

There are three basic features that distinguish the Berlin Rules from the Helsinki Rules and the 1997 UN Watercourse Convention. First, the Berlin Rules can be used for both national and international waters. The concern has been raised that "the wisdom of application of principles of international law [is being applied] to waters that are exclusively domestic." ${ }^{40}$ Second, the Berlin Rules have overstepped the scope of the ILA, considered the established principles of customary international law, and also included a number of emerging principles. In the Helsinki Rules and the 1997 UNWC, the established principles are legally binding, and the emerging principles are not. But in the Berlin Rules, the established principles of customary law and the emerging principles have been treated equally. Third, the Berlin Rules treat the

\footnotetext{
${ }^{37}$ Flavia Rocha Loures and Alistair Rieu-Clarke (eds), The UN Watercourse Convention in Force: Strengthening International Law for Transboundary Water Management (UK, 1st, Routledge, 2013) 64.

${ }^{38}$ Salman (n 34) 632.

${ }^{39}$ Salman (n 34) 635-38.

${ }^{40}$ Salman (n 34) 638.
} 
principle of equitable and reasonable utilization and the principle of obligation not to cause significant harm equally, which is a sharp contrast to both Helsinki Rules and the 1997 UN Watercourse Convention. Both of the preceding instruments attach greater importance to the principle of equitable and reasonable utilization than the principle of obligation not to cause significant harm.

These points have also made the Berlin rule controversial and thus incapable of gaining a more stable and legal position on the international stage.

\subsubsection{Other Water Related International Law}

There are also other international laws with content related to water resources conservation, especially the international law of nature conservation. For example, the Convention on Biological Diversity (CBD) has provisions on habitat conservation, which can be connected with international watercourse conservation because water resources are a necessary element of ecosystems. ${ }^{41}$ According to this explanation, the Convention on the Conservation of Migratory Species of Wild Animals (CMS) ${ }^{42}$ the Ramsar Convention (Convention on Wetlands of International Importance, especially as Waterfowl Habitat), ${ }^{43}$ the Convention to Combat Desertification (UNCCD) ${ }^{44}$ and so forth can also be included in the category of water-related international law.

\footnotetext{
${ }^{41}$ Convention on Biological Diversity [1992] UNTS 1760/79; ILM $31 / 818$ (1992), preamble: “Noting further that the fundamental requirement for the conservation of biological diversity is the in-situ conservation of ecosystems and natural habitats and the maintenance and recovery of viable populations of species in their natural surroundings" <https://www.cbd.int/doc/legal/cbd-en.pdf> accessed 26 October 2016.

${ }^{42}$ Convention on the Conservation of Migratory Species of Wild Animals [1979] UNTS 1651/333; ILM 19/15 (1980); ATS 1991/32; BTS 87 (1990), Cm. 1332, art 2: "to conserve such species and their habitat" <http://www.cms.int/sites/default/files/instrument/CMS-text.en_.PDF> accessed 26 October 2016.

${ }^{43}$ Ramsar Convention [1971] UNTS 996/245; TIAS 11084; ILM 11/963 (1972), preamble: "Considering the fundamental ecological functions of wetlands as regulators of water regimes and as habitats supporting a characteristic flora and fauna, especially waterfowl." <http://www.ramsar.org/sites/default/files/documents/library/scan_certified_e.pdf> accessed 26 October 2016.

${ }^{44}$ Convention to Combat Desertification [1994] 1954 UNTS 3; 33 ILM 1328 (1994), prologue: “arid, semi-arid and dry sub-humid areas together account for a significant proportion of the Earth's land area and are the habitat and source of livelihood for a large segment of its population." <http://www.unccd.int/en/about-the-convention/Pages/Text-overview.aspx> accessed 26 October 2016.
} 
Some general international environmental laws also provide general principles and useful mechanisms for international water law, including: the 1972 Stockholm Declaration; the 1992 Rio Declaration, which mentioned the principle of sustainable development and the principle of common but differential responsibility; the Aarhus Convention, which aims at public participation; and the Espoo Convention, which aims at environmental impact assessment. These general international environmental laws also have important relationship with the international water law, and can be a foundation for future development of the international water law. ${ }^{45}$

\subsection{Customary International Law for Water Resources}

In international law, except the treaty law, the customary international law is also a formal and vital source. ${ }^{46}$ The definition of the customary international law is "those rules of international law that derive from and reflect a general practice accepted as law". ${ }^{47}$ This definition contains two elements: the first element is a State practice with generality, uniformity and consistency, ${ }^{48}$ and the second element is the practice accepted as law by a State. ${ }^{49}$ The general customary international law is legally binding upon the entire international community, while the regional one is legally binding to a group of or only two States. ${ }^{50}$ However, the regional customary international law can derogate or sometimes supplement the general customary international law. ${ }^{51}$

The instruments that have been introduced in former sections have also contents that reflect rules of the customary international law, especially the 1966 Helsinki Rules and the 1997 UNWC. The rules are quite vital for all state practices on affairs of the international watercourse. These rules contain: the principle of "restricted sovereignty" which is related to principle of equitable utilization, ${ }^{52}$ the precautionary principle,${ }^{53}$ the

\footnotetext{
${ }^{45}$ Laurence Boisson de Chazournes, Fresh Water in International Law (UK, 1st, Oxford University Press, 2013) 117, 119, 140, 142.

${ }^{46}$ Alina Kaczorowska-Ireland, Public International Law (UK, 5th, Routledge, 2015) 30.

${ }^{47}$ Ibid.

${ }^{48}$ Kaczorowska-Ireland (n 46) 31-34.

${ }^{49}$ Kaczorowska-Ireland (n 46) 30.

${ }^{50}$ Kaczorowska-Ireland (n 46) 31.

${ }^{51}$ Ibid.

${ }^{52}$ Dellapenna (n 28) 269-273.
} 
principle of sustainable development, ${ }^{54}$ the obligation to prevent transboundary pollution, ${ }^{55}$ the duty to provide to relevant States prior notice of plans to exploit a shared natural resource, ${ }^{56}$ the duty to cooperate, ${ }^{57}$ and so forth.

\subsubsection{The Relationship between the International legal Water Regime of the Mekong River Basin and these International Water and Water-related Instruments}

As the only one from the Mekong River basin, Vietnam became the $35^{\text {th }}$ party to the 1997 UNWC on 19 May 2014. Its ratification was quite a crucial step for the Convention, bringing the number of State Parties to $35 .{ }^{58}$ Thus, on the one hand, the 1997 UNWC actually entered into force on 17 August 2014. On the other hand, compared with the Helsinki Rules and the Berlin Rules, the 1997 UNWC now plays a more important role for the Mekong River basin and can to some extent conduct the Mekong water regime's improvements in the future..$^{59}$

As for the Mekong water regime customary international law guides its operation, and the general customary international law is binding upon all countries in the Mekong River basin. ${ }^{60}$ Many rules of the water-related customary international law can be reflected in the 1997 UNWC. ${ }^{61}$ Therefore, even though the Convention is a treaty law, but some of its provisions are still binding to non-parties, due to the provisions' character as recognized customary international law. In the Mekong River basin, most of its riparian countries are not parties to the Convention. However, based on the effects of the customary international law, the Mekong river basin can also be

\footnotetext{
${ }^{53}$ Owen McIntyre, 'The Role of Customary Rules and Principles in the Environmental Protection of Shared International Freshwater Resources’ (2006) 46 Natural Resource Journal 157, 161.

${ }^{54}$ Ibid.

${ }^{55}$ McIntyre (n 53) 169-170.

${ }^{56}$ McIntyre (n 53) 184.

${ }^{57}$ McIntyre (n 53) 186.

${ }^{58}$ Gabriel Eckstein (ed), 'Specially invited opinions and research report of the International Water Law Project: global perspectives on the entry into force of the UN Watercourses Convention 2014: part one' (2014) 16 Water Policy 1198, 1198.

${ }^{59}$ Boer, Hirsch, Johns, Saul and Scurrah (n 11) 8.

${ }^{60}$ Kaczorowska-Ireland (n 46) 31.

${ }^{61}$ Owen McIntyre, 'Utilization of shared international freshwater resources - the meaning and role of “equity” in international water law' (2013) 38/2 Water International 112, 112.
} 
regulated by certain provisions from the 1997 UNWC. The two upper stream countries, China and Burma, are not members of the Mekong water regime. In this situation, the customary international law can also play essential role for regulating the relations between these two countries and other four lower stream countries.

Some other water-related international environmental laws can provide some principles, rules and mechanisms for water resources conservation and management in the Mekong River basin. The riparian states of the Mekong River have already signed some water-related instruments, such as the Rio Declaration and the Convention on Biological Diversity, and some contents from them can be utilized to some extent, which, in the long run, can also help the water regime in the Mekong River basin to be improved. ${ }^{62}$

\subsubsection{The 1995 Mekong Agreement}

The 1995 Mekong Agreement is also called "The Agreement on the Cooperation for the Sustainable Development of the Mekong River Basin”, which is a regional treaty among four lower Mekong River basin States: Thailand, Cambodia, Laos and Vietnam. ${ }^{63}$ This treaty entered into force on April 5, 1995 and is the only specific legally binding instrument for cooperation in sustainable development, reasonable and equitable utilization, environmental conservation and management of the Mekong River Basin. ${ }^{64}$

Based on this Agreement, the Mekong River Commission was established, which is responsible for coordination of water resources development and related natural resources and environmental conservation in the Lower Mekong River Basin. ${ }^{65}$ As the only specific legal instrument of the Mekong water regime, the Mekong Agreement, a

\footnotetext{
${ }^{62}$ Boisson de Chazournes (n 45) 111, 117.

${ }^{63}$ Scott C. Armstrong, 'Water Is for Fighting: Transnational Legal Disputes in the Mekong River Basin' (2015) 17 Vermont Journal of Environmental Law 1, 6.

${ }^{64}$ Paisly, Weiler and Henshaw (n 18) 44.

${ }^{65}$ George Radosevich, Olivier Cogels, John Dore, John Metzger, Pech Sokhem, Maaria Curlier and Theressa Etmanski, 'In-Depth Case Study for the Mekong River Basin: the 1995 Agreement on the Cooperation for Sustainable Development of the Mekong River Basin System', GEF Transboundary Freshwater and Marine Legal and Institutional Frameworks Project, International Waters Governance $<$ http://www.internationalwatersgovernance.com/uploads/1/3/5/2/13524076/mekong.pdf> accessed 29 September 2016, 18.
} 
more detailed introduction and analysis of this agreement and its institution will be explicitly outlined in a subsequent and independent section.

\subsubsection{Other Relevant Regional Arrangements}

Besides the former instruments of the Mekong water regime, there are also some related instruments at the regional level. Most of them aim at economic goals, but the contents of these instruments contain some relevant elements of the water regime. To some extent, these relevant instruments could also affect the development of the Mekong water regime and make a contribution to the improvements to the Mekong water regime.

\subsubsection{The Great Mekong Sub-region Program}

In 1992, based on the assistance from the Asian Development Bank (ADB), the six riparian countries of the Mekong River, which include Cambodia, the Peoples' Republic of China, the Lao People's Democratic Republic, Myanmar, Thailand, and Vietnam, entered into the Great Mekong Sub-region (GMS), which is a program of sub-regional economic cooperation. ${ }^{66}$ The aim of this program is to improve the regional infrastructure and foster trade and investment cooperation, and also enhance other relative fields. ${ }^{67}$ The GMS Program helps the "implementation of high priority sub-regional projects in transport, energy, telecommunications, environment, human resource development, tourism, trade, private sector investment, and agriculture. ${ }^{{ }_{68}}$ In fact, the GMS has made some achievements in different aspects, which has also promoted the regional development of the Mekong River basin. ${ }^{69}$

In 2006, the GMS countries launched the Core Environment Program (CEP), a program related to the sustainable use of shared natural resources and environment. ${ }^{70}$ According to a series of environmental tools and processes, including environmental assessments, sustainable planning, piloting innovation, and monitoring, the CEP has

\footnotetext{
${ }^{66}$ Haiyun Chen, Ting Zhu, 'The complexity of cooperative governance and optimization of institutional arrangements in the Greater Mekong Subregion' (2016) 50 Land Use Policy 363, 364-65.

${ }^{67}$ Chen, Zhu (n 66) 365.

${ }^{68}$ ADB, 'Overview of the Greater Mekong Subregion' (Official Website of Asian Development Bank) <http://www.adb.org/countries/gms/overview> accessed 02 October 2016.

${ }^{69}$ Ibid.

${ }^{70}$ ADB-GMS, 'The Core Environment Program' (Official Website of ADB-GMS Core Environment Program) <http://www.gms-eoc.org/the-program $>$ accessed 02 October 2016.
} 
also made contributions to the improvement of equitable, efficient, and sustainable natural resource (particularly hydropower) utilization and conservation of the environment in the Mekong River Region. ${ }^{71}$

The cooperation between the MRC and the GMS Program is reflected in many notable aspects. Firstly, as the main founder of the GMS, the ADB holds the position of regular observer at MRC Joint Committee and Council Meeting, and is also an active participant in the MRC Donor Consultative Group and technical meeting. ${ }^{72}$ Secondly, the MRC is an invited participant in the development partners' session of the GMS ministerial meeting, and also participates in the technical working groups, which focus on the environment, transport, agriculture and regional power trade. ${ }^{73}$ Thirdly, two organizations have also begun to cooperate in flood management and mitigation efforts. ${ }^{74}$ The ADB contributes to the MRC Flood Management and Mitigation Programme, as well as to the GMS's Program on Flood Control and Water Resource Management. Fourthly, to mitigate the adverse environmental impacts, the MRC established a program responsible for monitoring and assessments. This program works with some partners, including the ADB-facilitated GMS environment operations center. ${ }^{75}$ Fifthly, there are also other cooperative efforts towards the conservation of Tonlé Sap, advancing sustainable hydropower, managing tributaries, and climate change. ${ }^{76}$

In some fields the GMS and the MRC are in competition, but the MRC's main task of ensuring the water resources sustainable development makes the MRC always in the center of the Mekong water regime..$^{77}$ The GMS Program is not specifically a program for water resources, but it mentions the vital position of the natural resources in the

\footnotetext{
${ }^{71}$ Ibid.

${ }^{72}$ Mekong River Commission, 'Development Partners \& Partner Organisations' (Official Website of MRC) <http://www.mrcmekong.org/about-mrc/development-partners-and-partner-organisations/> accessed 02 October 2016.

${ }^{73}$ Mekong River Commission, 'The Mekong Connection: ADB, GMS, and MRC Working Together fore the Region' (2000) The Mekong River Commission Publication, 2 <http://www.mrcmekong.org/assets/Publications/leaflet/mekong-connection.pdf> accessed 29 September 2016.

${ }^{74}$ Ibid.

75 Ibid.

${ }^{76}$ Ibid.

${ }^{77}$ Boer, Hirsch, Johns, Saul and Scurrah (n 11) 16.
} 
Mekong River basin and has the intention of promoting the sustainable utilization of those natural resources. Some tools and processes of the CEP can be utilized for shared water resources conservation. Cooperation between the MRC and the GMS could also enhance the regional water resource management and development. Another advantage of the GMS program is that all the riparian countries of the Mekong River have already joined this program. This program can be used for coordinating relations between the Lower Mekong River Basin States (LMRBS), which include Thailand, Laos, Cambodia and Vietnam, and the upper-stream countries, namely China and Myanmar. ${ }^{78}$ The two upper-stream states are not member states of the Mekong Agreement. Therefore, the GMS program can play a complimentary, strengthening role for the Mekong water regime.

\subsubsection{Global Water Partnership Southeast-Asia (GWP-SEA)}

The Global Water Partnership Southeast-Asia was born in 2004, and its mission is to encourage, support, and facilitate member countries in achieving sustainable water through the Integrated Water Resources Management (IWRM) approach. ${ }^{79}$ It is a component of the Global Water Partnership, which was founded in 1996 by the World Bank, the United Nations Development Programme (UNDP), and the Swedish International Development Cooperation Agency (SIDA) to foster IWRM. The IWRM approach is a process that promotes the coordinated development and management of water, land and related resources in order to maximize economic and social welfare without compromising the sustainability of ecosystems and the environment. ${ }^{80}$

GWP membership is open to all organizations related to water and water resource management. Currently, the GWP-SEA network has over 360 member organizations

\footnotetext{
${ }^{78}$ Truong-Minh $\mathrm{Vu}$, 'Between system maker and privileges taker: the role of China in the Greater Mekong Sub-region’ (2014) 57 Revista Brasileira de Política Internacional 157, 161.

${ }^{79}$ Global Water Partnership Southeast Asia, 'About' (Official Website of the Global Water Partnership Southeast Asia <http://www.gwp.org/GWP-South-East-Asia/ABOUT-GWP-SEA/> accessed 29 September 2016.

${ }^{80}$ Global Water Partnership, 'About GWP' (Official Website of the Global Water Partnership) <http://www.gwp.org/en/About-GWP/> accessed 29 September 2016.
} 
in the 9 SEA countries: Cambodia, Indonesia, the Lao PDR, Malaysia, Myanmar, Philippine, Singapore, Thailand and Vietnam. ${ }^{81}$

According to the statutes of the GWP-SEA, its objective is "to promote the principle of IWRM, and, to that end: (a) to identify the critical needs of the region and riparian countries and stimulate partners to meet these needs with their available human and financial resources; (b) to support action at regional, national, local or river basin levels that will lead to the adoption and implementation of the principles of IWRM; (c) to help match needs to available resources; (d) to strengthen mechanisms for sharing information and experience." ${ }^{92}$

The GWP-SEA includes five riparian countries of the Mekong River basin. Although China is not a member of the GWP-SEA, the Global Water Partnership China, which is also under the guidance of the GWP, ${ }^{83}$ allows China to connect with member countries of the GWP-SEA in some respects.

As a main origin of fresh water resources in Asia, the Mekong River's water management can also be promoted by the GWP-SEA. Some of the objectives of the GWP-SEA can be connected to the principles of the Mekong Agreement, and therefore the GWP-SEA can improve the functions of the Mekong water regime. For instance, the approach of IWRM has also been utilized by the MRC in its basin planning, and in 2011 the IWRM based Basin Development Strategy was adopted by the lower Mekong Countries under the framework of the 1995 Mekong Agreement. ${ }^{84}$

\subsubsection{The ASEAN-Mekong Basin Development Cooperation (AMBDC)}

On 17 June 1996, the ministers and representatives of Brunei Darussalam, Cambodia, China, Indonesia, Laos, Malaysia, Myanmar, the Philippines, Singapore, Thailand and Vietnam, as the core group, met in Kuala Lumpur and agreed to follow the Basic

\footnotetext{
${ }^{81}$ Global Water Partnership Southeast Asia, 'The Partnership Network' (Official Website of the Global Water Partnership Southeast Asia) <http://www.gwp.org/en/GWP-South-East-Asia/ABOUT-GWP-

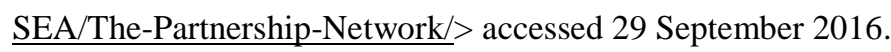

${ }^{82}$ Statutes Southeast Asia Regional Water Partnership 2008, art 2 <http://www.gwp.org/Global/GWPSEa_Files/011\%20-\%20GWP-SEA\%20Statutes\%2029Feb2008.pdf> accessed 29 September 2016.

${ }^{83}$ Global Water Partnership, 'China' (Official Website of the Global Water Partnership) http://www.gwp.org/en/gwp-in-action/China/> accessed 02 October 2016.

${ }^{84}$ MRC, 'Basin Planning' (Official Website of the MRC) < http://www.mrcmekong.org/topics/basinplanning/> accessed 02 October 2016.
} 
Framework of the ASEAN-Mekong Basin Development Cooperation by "realizing the great potential of economic growth of the Mekong Basin and desiring to cooperate in the development of the Mekong Basin." ${ }^{95}$

The AMBDC aims to promote economic integration among the Member Countries and simultaneously help to build the ASEAN Economic Community by 2015. Its basic framework for cooperation has contributed to the development of the infrastructure and human capital in the sub-region. Additionally, this framework has also promoted resource sharing between ASEAN countries, Mekong riparian countries, and China.

According to the Basic Framework of the AMBDC, there are three objectives of this cooperation: "To enhance economically sound and sustainable development of the Mekong Basin; To encourage a process of dialogue and common project identification which can result in firm economic partnerships for mutual benefit; and To strengthen the interconnections and economic linkages between the ASEAN member countries and the Mekong riparian countries." $\$ 6$

The cooperation should also be governed by six principles. The third and fourth principles are related to environmental protection and natural resources conservation and mention sustainable development, reasonable utilization, and the cooperation with the Mekong River Commission (MRC). ${ }^{87}$

In summary, the AMBDC is important as an instrument for promoting the sustainable development of the Mekong River Basin. It also strengthened the relationship between the ASEAN and the Mekong River basin. As a simultaneous policy dialogue for ASEAN and China to foster sub-regional economic growth, poverty alleviation and cooperation, AMBDC also plays a helpful role. ${ }^{88}$ As for the aspect of the Mekong

\footnotetext{
${ }^{85}$ Basic Framework of ASEAN- Mekong Basin Development Cooperation [1996] ASEAN, Paragraph

<http://www.asean.org/storage/images/2012/Economic/AMBDC/Basic\%20Framework\%20of\%20ASE AN-\%20Mekong\%20Basin\%20Development\%20Cooperation.pdf> accessed 02 October 2016.

${ }^{86}$ Basic Framework of ASEAN- Mekong Basin Development Cooperation (n 70) A. Objectives.

${ }^{87}$ Basic Framework of ASEAN- Mekong Basin Development Cooperation (n 70) B. Principles of Cooperation.

${ }^{88}$ ASEAN, 'Overview' (Official Website of the ASEAN) <http://asean.org/asean-economiccommunity/asean-mekong-basin-development-cooperation-ambdc/overview/> accessed 02 October 2016.
} 
water regime, the AMBDC can also be treated as a relevant source of soft law and be utilized to strengthen the cooperation on water resources utilization and conservation.

\subsubsection{The ASEAN Working Group on the Water Resource Management (AWGWRM)}

Based on the ASEAN Cooperation on Environment, the ASEAN Leaders established the ASEAN Working Group on Water Resources Management (AWGWRM), the objective of which is to enhance the regional cooperation on freshwater management. The aims of this working group are to: "promote networking and engage in collaborative action towards the practical implementation of integrated water resources management; promote and facilitate the exchange of relevant information, expertise, technology and know-how among water resource agencies of member countries; and provide or make arrangements for relevant training, education and awareness-raising campaigns." 89

Some of the key issues this working group deals with are supply, demand and allocation; water quality and sanitation; climate change and extreme events; governance and capacity building. ${ }^{90}$

Except China, the other riparian countries of the Mekong River are all member states of the ASEAN and also joined in the AWGWRM. Some contents from the "ASEAN Strategic Plan of Action on Water Resources Management" will therefore also affect the Mekong water regime and be helpful for keeping the balance between economic growth and the sustainable environmental development of the Mekong River Basin.

\subsection{Analysis of the 1995 Mekong Agreement and MRC}

\subsubsection{Historical Background}

After over 40 years of regional and international efforts to establish cooperation on the development and management of water and related resources in the Mekong River basin, the 1995 Agreement was finally concluded. Before this agreement came out,

\footnotetext{
${ }^{89}$ ASEAN, 'ASEAN Cooperation on Water Resources Management' (Official Website of the ASEAN) <http://environment.asean.org/asean-working-group-on-water-resources-management-awgwrm/> accessed 02 October 2016.

${ }^{90}$ ASEAN Strategic Plan of Actions on Water Resources Management [2005] ASEAN, 8. Key Issues <http://environment.asean.org/files/ASEAN\%20Strategic\%20Plan\%20of\%20Action\%20on\%20Water \%20Resources\%20Management.pdf> accessed 02 October 2016.
} 
the Mekong River Basin had already experienced two different periods and been managed by two historical water regimes. These two periods also played very vital role for the foundation of the 1995 Mekong Agreement and the Mekong River Commission.

\subsubsection{Different Periods of Its Development}

\subsection{Mekong Committee Era (1958-1975)}

The Mekong water regime initially developed in the mid-1950s, which was a very unstable time for Southeast Asia. ${ }^{91}$ Thailand itself remained firmly in the capitalist camp. After colonial times, Vietnam was divided into two parts: Ho Chi Minh's communist government was supported by China and the Soviet Union and held North Vietnam. In South Vietnam, the government was supported by United States, which was against communism and its advances in Asia. Laos suffered a civil war, with the communist forces on one side and the capitalist forces on the other. Cambodia wanted to remain neutral by facing the military conflicts between two different camps. ${ }^{92}$

The initial exploration of the water resource development options for the Mekong River was undertaken in the mid-1950s by the United Nation's Economic Commission for Asia and the Far East (ECAFE) and the United States' Bureau of Reclamation. ${ }^{93}$ During this period, the 15 million residents who lived along the Mekong River were very poor and eager to improve their quality of life. ${ }^{94}$ The reconnaissance missions of the ECAFE and United States' Bureau of Reclamation therefore decided that the building of a dam might be a way out of poverty for these people because the dam would act to control flows while simultaneously producing hydroelectric power, increasing dry season irrigation and improving navigation. ${ }^{95}$ The UN and some other pro-Western governments also hoped that the water resource

\footnotetext{
${ }^{91}$ Browder and Ortolano (n 12) 504.

${ }^{92}$ Browder and Ortolano (n 12) 504.

${ }^{93}$ Jeffrey W. Jacobs, 'The Mekong River Commission: transboundary water resources planning and regional security' (2002) 168/4 The Geographical Journal 354, 356.

${ }^{94}$ Browder and Ortolano (n 12) 505.

95 Jacobs (n 93) 357.
} 
management in the Mekong region would help Southeast Asia to be more united and to have a greater ability to impede the communist camp's advance. ${ }^{96}$

In 1957, the governments of Thailand, Cambodia, Laos and South Vietnam endorsed the statute of the "Committee for Coordination of Investigations in the Lower Mekong Basin". China and Burma were not members at that time. This statute became the first constitutional basis for the Mekong water regime. The aim of this document was to "promote, coordinate, supervise and control the planning and investigation of water resources development projects in the Lower Mekong basin" (Art. 4). This aim was limited to and only concentrated on planning development of water resources. ${ }^{97}$ The Committee consisted of 4 members from each of the four countries. Governments from Europe, the USA, and Japan provided funding for the Committee's studies and plans. The Mekong River Commission Secretariat (MRCS) consisted of 100 members from Lower Mekong countries, the UN and the donor countries, which was expected to support the Committee in mobilizing the technical and financial resources. ${ }^{98}$

There were two main principles for Mekong Committee: "As a result of the projects recommended (by the Mekong Committee), the existing low water discharge of the Mekong would not be reduced in any way at any site"; and "The supplies to be diverted for irrigation purposes would be met by some storage of flow during high stages of the river." Both of these seem restrictive for up-stream countries.

In 1975, the Mekong Committee issued a Joint Declaration, which agreed that the unanimous approval of the Mekong Committee was the premise for implementation of all mainstream, major tributary and inter-basin diversions. The contents of this Joint Declaration also included ecological impact studies on the project's implementation, damage compensation, maintenance of the minimum flows and mainstream water resources (Art. 10.17.18.20.21).

This Joint Declaration does not appear to respect the principle of sovereignty, but was nonetheless expected to benefit the member states. Because it was not submitted for ratification but rather simply signed by four of the member states, its legal character

\footnotetext{
${ }^{96}$ Jeffrey W. Jacobs, 'Mekong Committee History and Lessons for River Basin Development' (1995) 161/2 The Geographical Journal 135, 139.

${ }^{97}$ Browder and Ortolano (n 12) 506.

${ }^{98}$ Browder and Ortolano (n 12) 506.
} 
was controversial. Nevertheless, the 1975 Joint Declaration was still a milestone for the Mekong water regime, and mentioned some vital and controversial issues thereof. In mid-1975, North Vietnam conquered South Vietnam and unified the country. Communist forces also controlled Cambodia and Laos at that time. Only Thailand stayed in the capitalist camp. The integrated development of the Mekong River had to be broken off, and the Mekong Committee's efforts up to that point therefore failed as well.

\subsection{Interim Mekong Committee (1978-1992)}

By 1978, the diplomatic relationship among the countries in Southeast Asia had been reestablished. This was a vital prerequisite for rebuilding the Mekong water regime. With assistance from the United Nations' Economic and Social Commission for Asia and the Pacific (ESCAP), Thailand, Laos and Vietnam signed the 1978 Interim Mekong Committee (IMC) Declaration. ${ }^{99}$ Cambodia was not inclined to become a member because of its national policy of "self-reliance". ${ }^{100}$

The 1978 Declaration was a new constitutional document for the Mekong water regime based on new realities in Southeast Asia. All three members wanted to receive technical and financial assistance from the Mekong water regime. As had been stated in 1978, "the functions of the Interim Committee are to promote the development of water resources of the Lower Mekong Basin." These functions were more restrictive than what been stated by the Mekong Committee and meant that the IMC's main role was to obtain assistance from donors. ${ }^{101}$ There were also provisions for readmitting Cambodia into the Mekong, which created ambiguity concerning the effects of the Mekong Committee's institutional documents. ${ }^{102}$

In the 1980s, the instability of the ideological, political and military context in Southeast Asia unfortunately also affected the running of the IMC and rendered the IMC's delegation meetings non-productive. Apart from these difficulties, the United Nations Development Programme (UNDP) and donors supplied assistance and helped the IMC to survive this unstable situation. With an insufficient budget, IMC changed

\footnotetext{
${ }^{99}$ Browder and Ortolano (n 12) 509.

${ }^{100}$ Browder and Ortolano (n 12) 510.

${ }^{101}$ Ibid.

102 Ibid.
} 
its focus from mainstream projects to data collection, training and projects within a single country.

In 1990, the Thai government decided to launch a project that focused on the poverty of the residents in the arid northeast of Thailand. The core objective of this reforestation and water resource development project was to divert water from the Mekong River into the Chi and Mun rivers. It was expected to enhance the irrigation of the relevant region. The Vietnamese government warned the Thai and expressed their concern that this project would potentially harm the agriculture of the Mekong Delta (which was called the "rice bowl" of Vietnam), given that sufficient water is a very critical element for the Mekong Delta's agriculture, not only for irrigation but also for defending against the intrusion of seawater. ${ }^{103}$

At the beginning of the 1990s, China also started to undertake water resource exploitation in the Mekong River and launched a huge hydroelectric development program. The regional demand for irrigation water from the Mekong in China, however, was not urgent. Therefore, these upper stream reservoirs can increase the dry season flow and also control the flow during flood season. ${ }^{104}$

In 1991, Cambodia received the opportunity to be readmitted to its former place on the Mekong Committee thanks to help from the United Nations, and it was eager to rebuild the domestic economy and to obtain aid from donors through the Mekong water regime. Although the Thai and Vietnamese governments were eager to readmit Cambodia, there was general disagreement on the new constitutional framework of the IMC. On one hand, Vietnam wanted to restore the constitutional rule of the former Mekong Committee stating that all proposed projects needed to be approved by the Committee. On the other hand, the Thai government held the perception that the IMC should serve a promotional but not a controlling or supervisory function, and Thailand therefore refused to submit the project to the IMC. Because of the impact of Chinese exploitation in the upper stream, Thailand also wanted to involve China in the Mekong water regime. ${ }^{105}$

In the end, the Mekong water regime almost collapsed due to the different perceptions of Thailand and Vietnam regarding the new structure of the Mekong water regime. In

\footnotetext{
${ }^{103}$ Browder and Ortolano (n 12) 512-13.

${ }^{104}$ Browder and Ortolano (n 12) 513-15.

105 Browder and Ortolano (n 12) 516.
} 
late 1992, a compromise plan was devised that would form the basis for negotiations on a new framework for cooperation between the four lower Mekong riparian countries. They would also invite China and Myanmar, the two upstream countries, to join. The UNDP also promised to lend assistance mediating and negotiating. ${ }^{106}$

In creating the new framework, the riparian countries expressed different concerns based on their different domestic interests. Vietnam suggested that an international organization for consultation and the protection of riparian rights would allow riparian countries to share the water resources more equitably. Thailand focused on water allocation, which caused a series of debates among the riparian states and was also related to China's activities. Laos was worried that the water allocation project in Thailand would cause ecological problems and wanted to establish an orderly way to monitor and allocate water in the basin, as well as to ensure that criteria for sharing water resources and a forum for consultation were in place.

At that time, the creation of a functional system for the sharing water of the Mekong River became more and more important, but no criteria were universally accepted. ${ }^{107}$ Upstream states had less motivation to conclude a water-sharing agreement than downstream states. Nevertheless, the Mekong states needed international assistance from donors and wanted to keep the Mekong water regime intact. ${ }^{108}$ Donor organizations, including the UNDP, the World Bank and the Asian Development Bank, were poised to increase their contributions if the member states could finally reach a compromise. ${ }^{109}$ After decades of cold war and ideological hostility, the relationship between the member states, especially between Thailand and Vietnam, turned in a more cordial direction. ${ }^{110}$

\subsubsection{Negotiation of the 1995 Mekong Agreement}

\subsection{Development of the Agreement}

Since Cambodia decided to join the Mekong water regime once again, the Committee's constitutional framework had been threatened and the Mekong water

\footnotetext{
${ }^{106}$ Ibid.

${ }^{107}$ Browder and Ortolano (n 12) 517.

${ }^{108}$ Browder and Ortolano (n 12) 517-18.

${ }^{109}$ Browder and Ortolano (n 12) 518.

${ }^{110}$ Ibid.
} 
regime needed to be restructured. ${ }^{111}$ Thailand wanted a new and less strict system of rules regarding prior notification. ${ }^{112}$ Additionally, the issue as to which countries would be involved also became contentious. Thailand wanted China and Myanmar to be included in the negotiations, but this idea was opposed by Vietnam. Vietnam wanted to negotiate firstly with the other three LMRB countries and to then present the agreed constitution to Myanmar and China. ${ }^{113}$

The UNDP provided neutral assistance in the negotiation process and did not want its investment to be eroded. It also agreed to provide technical and financial assistance for formulating a new constitutional framework. ${ }^{114}$ The UNDP organized an informal consultation in Hong Kong on October 6, 1992. This meeting was successful and was a catalyst for the follow-up meeting in Kuala Lumpur in mid-December of that year. At this historic meeting, the four parties drafted the key points that would form the basis of the future framework; these were drawn up as a Communiqué and Guidelines and officially approved in Hanoi on 5 February 1993 at a meeting of the Mekong Working Group (MWG). ${ }^{115}$

These Guidelines contain many important provisions on the parties' common interests and mutual acceptance. They acknowledge the political, economic and social changes that occurred in the sub-region, and that the Mekong region is an economically dynamic and vital part of the world faced with natural resource management and environmental protection challenges. ${ }^{116}$ The Guidelines stipulate the following six elements for the future framework of coordination. They are: A set of principles of sustainable utilization of water resources; An institutional structure and mechanism for coordination; A definition of the functions and responsibilities of the structure and mechanism; The legal basis for the governance and financial operation of the structure and mechanism; Future memberships of the structure; Management of the structure. ${ }^{117}$ In accordance with the decision made by the four LMRBS at the Hong Kong meeting in October 1992, China and Myanmar were not included in the

\footnotetext{
${ }^{111}$ Radosevich, Cogels, Dore, Metzger, Sokhem, Curlier and Etmanski (n 65) 10-12.

${ }^{112}$ Browder (n 21) 244-46.

${ }^{113}$ Browder (n 21) 247.

${ }^{114}$ Paisly, Weiler and Henshaw (n 18) 47.

115 Ibid.

${ }^{116}$ Paisly, Weiler and Henshaw (n 18) 47-48.

${ }^{117}$ Paisly, Weiler and Henshaw (n 18) 48.
} 
negotiations. Nevertheless, the four LMRBS did agree that the participation of China and Myanmar would be conducive to achieving their joint objectives.

Negotiations lasted 23 months, and for the sake of reaching a shared basis of common interest and a mutual consensus for the future framework, four LMRBS were also encouraged to make compromises.

\subsection{The Absentee Riparian Nations, Observers and Donors}

China and Myanmar were not parties to the 1995 Mekong Agreement, but are bound by customary international water law rules and have potential to join this agreement. ${ }^{118}$ The 1995 Agreement also recognized this reality and provided a mean for adding new parties. These two upstream countries thus became official "dialogue partners" in 1996. Accordingly, they may send representatives to the meeting, which is held by the Joint Committee (JC), in the autumn of each year. ${ }^{119}$ The 1995 Mekong Agreement also states that "any other riparian State, accepting the rights and obligations under this Agreement, may become a party with the consent of the parties." Some international organizations, such as the Asian Development Bank (ADB), the Association of Southeast Asian Nations (ASEAN), the International Union for Conservation of Nature (IUCN) and so forth, also have the right to attend and participate in Joint Committee and Council meetings with observer status. ${ }^{120}$ All donors can obtain the opportunity to engage in dialogs with the MRC through the Donor Consultative Group (DCG), which facilitates donor interactions and coordination. $^{121}$

\subsection{Negotiation Process}

The negotiations were guided by the principles of customary international law and the interests of four riparian countries. ${ }^{122}$ The Mekong Working Group (MWG) was established by four LMRBS and held five formal meetings and two informal technical drafting group meetings that also promoted the success of the process. The national MWGs required negotiations for a new international framework that would protect

\footnotetext{
${ }^{118}$ Radosevich, Cogels, Dore, Metzger, Sokhem, Curlier and Etmanski (n 65) 12; Alina KaczorowskaIreland, Public International Law (UK, 5th, Routledge, 2015) 31.

${ }^{119}$ Paisly, Weiler and Henshaw (n 18) 48.

${ }^{120}$ Ibid.

${ }^{121}$ Ibid.

${ }^{122}$ Paisly, Weiler and Henshaw (n 18) 48-49.
} 
the fundamental water resource interests of each member state. This new framework should be fair to every member and try to ensure that all members "win" or at least "not lose" based on cooperation with one another. ${ }^{123}$

\subsection{Main Issues that Arose During the Negotiations}

a. Responsibility for Damages

Compensation was the first issue brought up during the negotiations. Thailand treated "compensation" as a very sensitive term and suggested that it be replaced by the term "responsibility for damages". The other three members were initially extremely opposed to this suggestion, but were eventually convinced otherwise. ${ }^{124}$

\section{b. Dispute Resolution}

The dispute resolution mechanisms of the agreement were also a core issue of the negotiations. The Lao officials proposed that the disputes that could not be resolved by the MRC or the respective governments should be resolved by the international Court of Justice (ICJ) or by binding arbitration. The Thai government was opposed to this proposal because of its implied restriction on Thailand's development. ${ }^{125}$ This disaccord was eventually resolved by Article 35 of the 1995 Mekong Agreement, which states that the members would resolve disputes that the MRC and the respective governments could not resolve according to the principles of international law; namely, through the UN system and the ICJ. ${ }^{126}$

\section{c. Minimum Flows}

The issue of minimum flows was covered by Article 6 of the Mekong Agreement. Provision A of Article 6 mandates a minimum level of natural dry season flow. Additionally, Provision B provides Cambodia an acceptable natural reverse wet season flow for Tonlé Sap, thus making sure that, in the dry season, the flows back down the Tonlé Sap River to the Mekong river will be sufficient. ${ }^{127}$ The minimum dry and wet season flows addressed in the Agreement are also related to the saltwater

\footnotetext{
${ }^{123}$ Ibid.

${ }^{124}$ Paisly, Weiler and Henshaw (n 18) 49.

125 Ibid.

${ }^{126}$ Ibid.

${ }^{127}$ Paisly, Weiler and Henshaw (n 18) 49-50.
} 
intrusion in Vietnam and the navigability of the Mekong River in Laos. ${ }^{128}$ The Thai government was willing to give in to regional cooperation and realized that Chinese dams would increase the volume of flows in the dry season, which made this concession more acceptable. ${ }^{129}$

\section{d. Power to Review}

Article 5 of the Mekong Agreement dealt with the most controversial issue in the negotiations, which was the power to review proposed water uses. On the one hand, Laos, Cambodia and Vietnam were all agreed that the mainstream projects and diversions of water from the Mekong should be subject to prior agreement by the MRC. ${ }^{130}$ On the other hand, Thailand was opposed to the veto power of other states over its projects. Thailand preferred the ILC's rules, which required states to notify, consult or sign an agreement based on the decision of the Joint Committee. ${ }^{131}$ After several negotiating sessions and by virtue of a subsequent informal meeting of the Laos, Cambodian and Vietnamese delegations, these three countries finally came to a consensus on a proposal (introduced in 2.3.2.3.) that had also been accepted by the Thai delegation. Thailand was able to accept this proposal because "it would not threaten their proposed projects, and it limited the scenarios where prior agreement was required before a project could proceed". ${ }^{132}$ The proposal that the projects which affected their interest during the dry season needed prior agreement endured as well. 133

\subsection{Reasons of the Successful Negotiation on the Mekong Agreement}

Firstly, the historical relationship between the LMRBS was a major factor for the success of the negotiations. ${ }^{134}$ After nearly 37 years of interaction in the course of Mekong River basin management, all the LMRBS had obtained experience helpful towards continuing their efforts to come to an agreement. The LMRBS also had the

\footnotetext{
${ }^{128}$ Paisly, Weiler and Henshaw (n 18) 50.

${ }^{129}$ Ibid.

${ }^{130}$ Paisly, Weiler and Henshaw (n 18) 51.

${ }^{131}$ Paisly, Weiler and Henshaw (n 18) 50.

${ }^{132}$ Paisly, Weiler and Henshaw (n 18) 51.

133 Ibid.

${ }^{134}$ Ibid.
} 
benefit of shared data and information from the Mekong Committee and the IMC era. ${ }^{135}$

Secondly, the 1994 draft ILC report, the 1966 Helsinki Rules, other international water treaties, and customary international law provided a strong legal basis and affected the negotiations. This international legal basis provided a fundamental framework for the negotiations and was also useful when parties could not reach unanimous agreement. ${ }^{136}$

Thirdly, suitable negotiating approaches promoted consensus in the negotiations. The "one-nation basin" scenario was utilized to disengage the participants from their beliefs and perceptions (national boundaries were overlain in a later scenario to adjust interests). Another useful negotiating approach was to "first discuss and evaluate various options about the kind of agreement and basin organization", and then to discuss the options that would be included in the agreement and be implemented by the agreement's organization. This approach helped the parties to understand each other better and also to promote the best mutually acceptable option possible. ${ }^{137}$

\subsubsection{Introduction to the 1995 Mekong Agreement and the MRC}

The Mekong Agreement includes 42 Articles, which can be divided into six chapters. The first two chapters are the Preamble and the Definition of Terms. The third chapter and last two chapters, which are substantive provisions, consist of the objectives and principles of the agreement, addressing differences and disputes, as well as the final provision. The fourth chapter, which includes Articles 11 to 34, is an "institutional framework for cooperation in the Mekong River Basin" called the Mekong River Commission (MRC). ${ }^{138}$

\subsubsection{Aim}

The aim of the Mekong Agreement is expressed in the very first sentence of the agreement: to promote continuing cooperation "in a constructive and mutually beneficial manner for sustainable development, utilization, conservation and

\footnotetext{
135 Ibid.

136 Ibid.

${ }^{137}$ Paisly, Weiler and Henshaw (n 18) 51-52.

${ }^{138}$ Agreement on the Cooperation for the Sustainable Development of the Mekong River Basin [1995]

34 ILM 864 (1995) art 11 <http://www.mrcmekong.org/assets/Publications/policies/agreementApr95.pdf> accessed 26 October 2016.
} 
management of the Mekong River Basin water and related resources" for the four riparian countries. It also sets forth a framework for cooperation that is acceptable to all parties and consistent with the parties' purposes. ${ }^{139}$

\subsubsection{Substantive Provisions}

\subsection{Objectives}

\section{a. Article 1: Areas of Cooperation}

Article 1 explains the range of cooperation of the member states, encompassing "all fields of sustainable development, utilization, management and conservation of the water and related resources of the Mekong River Basin". These related resources include, yet are not limited to, "irrigation, hydro-power, navigation, flood control, fisheries, timber floating, recreation and tourism". The member states shall cooperate so as to "optimize the multiple-use and mutual benefits of all riparian states and to minimize the harmful effects that might result from natural occurrences and manmade activities". ${ }^{140}$

\section{b. Article 2: Projects, Programs and Planning}

According to Article 2, the member states shall "promote, support, cooperate and coordinate" the water resource development. As compared with the 1957 Statute of Mekong Committee, the Mekong Agreement focuses more on "coordination" than on the "control" of water resources development, which is now also the primary function of the Mekong water regime. ${ }^{141}$

Article 2 also requires the MRC to formulate a "basin development plan" (BDP), which may focus on helping to coordinate water resource development in order to avoid or minimize water conflict in the future and to maintain the aquatic ecology of the Mekong Basin.

The Mekong Agreement does not specify the BDP as being binding for member states, yet treats the BDP as an effective tool for coordinating water resource development and management. A BDP could also help garner international financing of water

\footnotetext{
139 The 1995 Mekong Agreement (n 138) Paragraph 1.

${ }^{140}$ The 1995 Mekong Agreement (n 138) art 1.

${ }^{141}$ Browder and Ortolano (n 12) 522.
} 
projects. Drafting a BDP will not be a simple task, as there are multiple and conflicting objectives that must be considered and coordinated. ${ }^{142}$

\section{c. Article 3: Protection of the Environmental and Ecological Balance}

Article 3 focuses on the environmental protection and ecosystem conservation related to "the environment, natural resources, aquatic life and conditions, and ecological balance of the Mekong River Basin". This article also emphasizes the problems of pollution and utilization of water resources as the two main reasons for harmful effects. ${ }^{143}$

\section{d. Article 4: Sovereign Equality and Territorial Integrity}

This article states that member states shall cooperate with each other on the basis of sovereignty equality and territorial integrity in the utilization and protection of the water resources. ${ }^{144}$

\section{e. Article 5: Reasonable and Equitable Utilization}

The four member states all accepted the general principle of "reasonable and equitable utilization" of international waters. This doctrine has a supporting basis that is a water allocation system, which will not constrain national sovereignty excessively. In contrast to the two former periods, the Mekong Agreement focuses on procedures and principles for the review of proposed water uses, and "represents a balance between the strict requirements of the Mekong Committee and the absence of reviews in the IMC era." 145

After extensive negotiations, a compromise solution was reached and is summarized as follows: Firstly, notification to the Joint Committee of the MRC is necessary in all seasons for proposed water uses on the tributaries. Secondly, for proposed water uses on the mainstream: During the wet season, notification is necessary for intra-basin use, and inter-basin diversion shall be subject to prior consultation aiming at an agreement by the Joint Committee. During the dry season, prior consultation aiming at an

\footnotetext{
${ }^{142}$ Browder and Ortolano (n 12) 522-23.

${ }^{143}$ The 1995 Mekong Agreement (n 138) art 3.

144 The 1995 Mekong Agreement (n 138) art 4.

${ }^{145}$ Browder and Ortolano (n 12) 520.
} 
agreement by the Joint Committee is necessary for intra-basin use, and prior consultation and agreement for inter-basin diversions. ${ }^{146}$

"The Mekong Agreement does not specify the time frames for the wet and dry season, nor does it discuss the requirements for notification, prior consultation, or agreement." ${ }^{147}$ Instead, The Mekong Agreement requires the MRC to formulate the procedural details for the review of proposed water utilization (The details for reviewing the proposed utilization will be introduced in the section on the MRC entitled "Information Reporting"). Article 5 was the most contentious point of negotiation, and it is also representative of the complexity and ambiguity of the allocation issues, a considerable difficulty for the Mekong water regime.

\section{f. Article 6: Maintenance of Flows on the Mainstream ${ }^{148}$}

The Mekong Agreement needs to protect the interests of all parties. Provision A of Article 6 preserves the principle that "the existing low water discharge of the Mekong would not be reduced in any way at any site" ${ }^{149}$ and requires the parties to maintain the natural dry season flow. This Provision protects important existing beneficial water use in Vietnam and Laos, which promotes irrigation and navigation and also prevents the salinization of the Mekong Delta. Protecting the dry season flow will also be beneficial to the balance of the aquatic ecosystem.

Provision B of Article 6 focuses on maintaining wet season flows, aiming to "enable the acceptable reverse flow of the Tonlé Sap to take place during the wet season." ${ }^{150}$ This provision protects Cambodia's existing use of wet season water to sustain the hydrological and ecological integrity of the Tonlé Sap, which is connected with the mainstream of the Mekong River and is sustained by the Mekong River's flows in wet season.

In fact, Article 6 represents allocation of water based on existing beneficial uses. It delegates the concrete responsibility for maintenance of flows to the MRC, and these

\footnotetext{
${ }^{146}$ Browder and Ortolano (n 12) 521.

${ }^{147}$ Ibid.

${ }^{148}$ Browder and Ortolano (n 12) 519-520.

${ }^{149}$ Browder and Ortolano (n 12) 519.

${ }^{150}$ Ibid.
} 
details can be found in the "Procedures for the Maintenance of Flows on the Mainstream". ${ }^{151}$

\section{g. Article 7: Prevention and Cessation of Harmful Effects}

By the development and utilization of the water resources or discharge of waste and return flows, the Member States need to make efforts to avoid, minimize and mitigate harmful effects on the environment, especially the effects related to water quantity and quality, and the ecosystem's conditions and balance.

When one (or more) states is notified with proper and valid evidence proving that this state is causing harmful effects to one or more riparian states due to its utilization of water or discharge of waste, this state shall eliminate the cause of harm at once.

\section{h. Article 8: State Responsibility for Damages}

When any riparian state's utilization of and/or discharge to waters of the Mekong River causes substantial damage to one or more riparian states, the party or parties concerned shall determine the cause, extent, and responsibility for damages based on principles of international law relating to state responsibility, and shall address and resolve all issues, differences and disputes according to Article 34 and 35 and the UN Charter in an amicable, timely and peaceful way. ${ }^{152}$

\section{i. Article 9: Freedom of Navigation}

As a vital element for transportation and communication to promote regional cooperation and to implement projects under the framework of the Mekong Agreement, freedom of navigation shall be accorded throughout the mainstream of the Mekong River without regard to the territorial boundaries. The Mekong River shall be kept free from any effects that may impair navigability, interfere with this right, or permanently make it more difficult. Navigational uses do not have priority over other uses, but they shall be incorporated into other mainstream projects.

\footnotetext{
${ }^{151}$ Procedures for the Maintenance of Flows on the Mainstream [2006] Mekong River Commission <http://www.mrcmekong.org/assets/Publications/policies/Procedures-Maintenance-Flows.pdf> accesses 02 October 2016.

${ }^{152}$ Charter of the United Nations [1945] 59 Stat. 1031; TS 993; 3 Bevans 1153, art 2: “All Members shall settle their international disputes by peaceful means in such a manner that international peace and security, and justice, are not endangered." $<$ https://treaties.un.org/doc/publication/ctc/uncharter.pdf $>$ accessed 26 October 2016.
} 
Riparian states may regulate the portion of the Mekong River within their territories, especially in sanitary, customs and immigration matters, police and general security. This Article also satisfied the concerns of Laos, which is the only landlocked country in the Mekong River Basin. ${ }^{153}$

\section{j. Article 10: Emergency Situations}

When special water quantity or quality problems constitute an emergency that requires an immediate response and these become known to a Party, this Party shall notify and consult directly and in a timely manner with all those concerned and the Joint Committee for the purpose of undertaking remedial actions.

\subsection{Principles in the 1995 Mekong Agreement}

The principles of the Mekong Agreement are connected with the principles of international public law, international environmental law and international water law. These principles could be expounded as follows:

\section{a. Principle of Sustainable Development}

The principle of sustainable development has played an important role in environmental protection since 1987, when the Report of the World Commission on Environment and Development defined it as "development that meets the needs of the present without compromising the ability of future generations to meet their own needs". Principles 4 and 25 of the Rio Declaration make clear that policies and activities in various fields, including environmental protection, must be integrated in order to achieve sustainable development. ${ }^{154}$ Since the 1992 UN Conference on Environment and Development in Rio de Janeiro, sustainable development has left significant traces in many international legal and non-legal instruments. The notion of "sustainable development" and a variety of sub-notions that derive from it, such as "sustainable use", "sustainable utilization", "maximum sustainable yield", and

\footnotetext{
${ }^{153}$ The 1995 Mekong Agreement (n 138) art 9.

${ }^{154}$ Lal Kurukulasuriya and Nicholas A. Robinson (ed), Training Manual on International

Environmental Law (1st, UNEP/Earthprint, 2006) 41

<http://www.unep.org/environmentalgovernance/Portals/8/documents/training_Manual.pdf $>$ accessed 29 September 2016.
} 
"sustainable management", have appeared in almost all important instruments in postRio time. ${ }^{155}$

This important principle is embodied in Articles 1 and 2 of the Mekong Agreement as well. The first sentence of Article 1 states: "To cooperate in all fields of sustainable development, utilization, management and conservation of the water", which places sustainable development first among the cooperative tasks. Article 2 then mentions "the sustainable benefits to all riparian States", which can be considered a sub-notion of sustainable development in that it is combined with national benefits.

\section{b. Principle of Cooperation}

The principle of cooperation originates from Article 74 of the UN Charter (the principle of "good-neighborliness") and has been translated into development and application of rules promoting international environmental co-operation. ${ }^{156}$ Article 74 has also been reflected in many treaties and international acts, especially in relation to hazardous activities and emergencies. Principle 24 of the Stockholm Declaration and Principle 27 of the Rio Declaration both embody this principle. The principle of cooperation has also important practical significance that has been reflected in many international instruments, such as the Preamble to the 1992 Industrial Accidents Convention and the procedural rules in the 1997 Watercourses Convention. ${ }^{157}$ Obligations to the principle of cooperation may be in general terms, relating to implementation of the treaty's objectives, or relating to specific commitments. Some general obligations have also been translated into specific commitments. These specific commitments include: rules on environmental impact assessment, rules on information reporting (information exchange, consultation, and notification), the provision of emergency information, and trans-boundary enforcement of environmental standards. ${ }^{158}$

\footnotetext{
${ }^{155}$ Ulrich Beyerlin, 'Sustainable Development', Max Planck Encyclopedia of Public International Law (Fall edn 2013), Paragraph 1 <http://opil.ouplaw.com/view/10.1093/law:epil/9780199231690/law9780199231690-e1609?rskey=x0kyma\&result=1\&prd=EPIL> accessed 29 September 2016.

${ }^{156}$ Philippe Sands, Jacqueline Peel, With Adriana Fabra, With Ruth MacKenzie, Principles of international environmental law (UK, 3rd edn, Cambridge University Press, 2012) 203.

${ }^{157}$ Sands, Peel, Fabra and MacKenzie (n 156) 204.

${ }^{158}$ Ibid.
} 
Based on these, some articles of the Mekong Agreement can be said to embody the principle of cooperation as well. Article 1, Article 2, Article 4 and Article 6 all use the term "to cooperate", and Article 9 on freedom of navigation aims "to promote regional cooperation". Article 10 deals with emergency situations in terms of the provision of emergency information, a specific commitment of the principle of cooperation. ${ }^{159}$

\section{c. Principle of Limited Territorial Sovereignty}

Limited territorial sovereignty is the dominant theory for state practices of international watercourse today, ${ }^{160}$ which means the sovereignty of a state over its territory is said to be 'limited'. ${ }^{161}$ This consists of two important aspects: Firstly, all riparian states (in principle) have equal rights to use the water resources, and must respect the rights of other states. ${ }^{162}$ This recognizes the value of freedom from unwanted interferences in person or property. ${ }^{163}$ Secondly, this point has also been translated to mean that riparian states should take reciprocal interests into consideration, ${ }^{164}$ which also means the obligation not to cause significant harm to other states. ${ }^{165}$ This theory solves some of the problems posed by the theories of "absolute territorial sovereignty" and "absolute territorial integrity" and has been applied in many state practices.

Article 4 of the Mekong Agreement reflects the first aspect of the limited territorial sovereignty theory. The title of the Article 4 is "Sovereignty Equality and Territory Integrity", which places the two elements at an equal level. Article 4 also treats the two elements equally, declaring that the parties should "cooperate on the basis of sovereign equality and territorial integrity in the utilization and protection of the water resources of the Mekong River Basin", which is abstract but still recognizes the riparian states' sovereignty regarding water resources uses. The contents of Article 7

\footnotetext{
${ }^{159}$ The 1995 Mekong Agreement (n 138) art 1, 2, 4, 6, 9, 10.

${ }^{160}$ Stephen McCaffrey, The law of international watercourses: Non-navigational uses (UK, 1st edn, Oxford University Press, 2001) 149.

${ }^{161}$ McCaffrey (n 160) 137.

${ }^{162}$ McCaffrey (n 160) 138.

${ }^{163}$ McCaffrey (n 160) 137.

${ }^{164}$ McCaffrey (n 160) 138.

${ }^{165}$ McCaffrey (n 160) 137.
} 
reflect the second aspect of limited territorial sovereignty theory, requiring the states "To make every effort to avoid, minimize and mitigate harmful effects". ${ }^{166}$

\section{d. Principle of Reasonable and Equitable Utilization}

The principle of reasonable and equitable utilization originating from decisions made by the US Supreme Court is the fundamental rule governing the use of international watercourses, ${ }^{167}$ and was first applied to them in the Helsinki Rules adopted by the International Law Association in August 1966. This principle also played an important role at the $1997 \mathrm{UN}$ Watercourse Convention. ${ }^{168}$ It requires watercourse states to utilize water resources in their respective territories in a reasonable and equitable manner that furthers the development and protection of the international watercourse. ${ }^{169}$ There are three conceptual elements of this principle: Firstly, it requires the watercourse states to engage in mutual consideration and coordination of interests. Secondly, the methods of considering interests need to be a consequence of the concept of equity and include consideration of all circumstances of a given case. Thirdly, the utilization shall be not only equitable but also reasonable because of the parallel position the two elements in this principle are allocated. ${ }^{170}$

Article 5 of the Mekong Agreement is entitled "Reasonable and Equitable Utilization" and requires that the states "utilize the waters of the Mekong River system in a reasonable and equitable manner in their respective territories, pursuant to all relevant factors and circumstances". In accordance with the core concept of this principle and the relationship between this principle and the principle of prevention of harm, Article 6 calls for maintenance of the mainstream flows and Article 7 for prevention and cessation of harmful effects can also (indirectly) be seen as reflections of the principle of reasonable and equitable utilization. ${ }^{171}$

\footnotetext{
166 The 1995 Mekong Agreement (n 138) art 4,7.

${ }^{167}$ McCaffrey (n 160) 345.

${ }^{168}$ McCaffrey (n 160) 324-25.

${ }^{169}$ Convention on the Law of the Non-Navigational Uses of International Watercourses [1997] UN

Doc A/RES/51/229, art 5 <http://legal.un.org/ilc/texts/instruments/english/conventions/8_3_1997.pdf> accesses 02 October 2016.

${ }^{170}$ McCaffrey (n 160) 162-63.

${ }^{171}$ McCaffrey (n 160) 380.
} 


\section{e. Principle of Prevention of Significant Harm}

The principle of responsibility not to cause environmental damage is an important element that originates from Principle 2 of the Rio Declaration and its predecessor Principle 21 of the 1972 Stockholm Declaration. This principle limits states' rights under sovereignty over natural resources, and requires states not to cause damage to the environment of other states or to areas beyond national jurisdiction. ${ }^{172}$ This principle reflects a rule of customary international law and also represents a limitation on the "rights of states in respect of activities carried out within their territory or under their jurisdiction". ${ }^{173}$ Another general principle of international environmental law, the principle of preventive action, has been endorsed in many international instruments, such as the 1972 Stockholm Declaration, the 1978 UNEP Draft Principles, and Principle 11 of the 1992 Rio Declaration. ${ }^{174}$ These two principles are closely related to one another with respect to the element of "harmful effects" or "damage", and both are reflected in international water law, as will be expounded upon in the following.

Article 7 of the 1997 UNWC states an obligation to "prevent the causing of significant harm", which reflects the general principle of preventive action, and has been treated as a fundamental obligation and general principle of international water law. ${ }^{175}$ This Article is more concrete than the general principle of preventive action, which focuses on harmful effects and expresses that the riparian countries should take all appropriate measures to prevent, eliminate or mitigate significant sources of harm. ${ }^{176}$ In Article 7 of the UNWC, the range of harm in the use of international watercourses has been limited. However, within the scope of state practices and some special situations, Article 7 has been interpreted broadly, considering both harm from activities indirectly affecting a watercourse and harm that is not necessarily related to the use of the watercourse. ${ }^{177}$ This principle works in tandem with the principle of

\footnotetext{
${ }^{172}$ McCaffrey (n 160) 195.

${ }^{173}$ McCaffrey (n 160) 196.

${ }^{174}$ McCaffrey (n 160) 202.

${ }^{175}$ McCaffrey (n 160) 346.

${ }^{176}$ The 1997 UNWC (n 169) art 7.

${ }^{177}$ McCaffrey (n 160) 349.
} 
reasonable and equitable utilization, of which the no-harm obligation is also a necessary part. ${ }^{178}$

Article 7 of the Mekong Agreement is entitled "Prevention and Cessation of Harmful Effects" and maintains that riparian states must "make every effort to avoid, minimize and mitigate harmful effects", thus embodying the principle of prevention of significant harm. The origins of such harm include "development and use of the Mekong River Basin water resources or discharge of wastes and return flows", which are essential to the environment and the ecosystem balance.

\section{f. Principle of Polluter Pays}

The Principle of Polluter Pays is one of the guiding principles of international environmental law and is closely related to the rules governing civil and state liability for environmental damages. It was first expressed in a 1972 OECD Recommendation, and has also been included in subsequent instruments, such as Principle 16 of the 1992 Rio Declaration. ${ }^{179}$ It stipulates that the polluter should bear the costs of the measures used for preventing or remedying damages. This principle has also been used in instruments of environmental protection of international freshwater resources, such as the 1990 ECE Code of Conduct on Accidental Pollution of Transboundary Inland Waters. ${ }^{180}$ Article $7(2)$ of the 1997 UNWC dictates that states must "take all appropriate measures...to eliminate or mitigate such harm and, where appropriate, to discuss the question of compensation" ${ }^{181}$; this, in turn, reflects a "State-run international law-making process aimed at the consolidation of the 'polluter-pays' principle within their domestic legal system". ${ }^{182}$ In mentioning such "compensation", Article 7(2) points out that the polluter-pays principle can be applicable at the domestic level and is "not necessarily restricted to a direct State-to-State interaction". ${ }^{183}$

\footnotetext{
${ }^{178}$ McCaffrey (n 160) 380.

${ }^{179}$ Owen McIntyre, Environmental Protection of international Watercourses under International Law (UK, 1st edn, Ashgate Publishing, 2007), 284.

${ }^{180}$ McIntyre (n 179) 285.

181 The 1997 UNWC (n 169) art 7.

${ }^{182}$ McIntyre (n 179) 285.

183 Ibid.
} 
In accordance with the above-mentioned, Article 8 of the Mekong Agreement can be also connected with the principle entitled "State Responsibility for Damages". This article states that the party concerned shall determine all factors related to damages "in conformity with the principles of international law relating to state responsibility", and "address and resolve all issues and differences in an amicable and timely manner by peaceful means as provided in Articles 34 and 35 of this Agreement, and in conformity with the Charter of the United Nations". ${ }^{184}$ Although it only cites state responsibility and does not directly mention the domestic legal system and compensation, according to its attitude towards the principle of international law and the UN Charter, its similarity to Article 7(2) of the 1997 UN Convention and the contents of Article 34 and Article 35 (which are resolutions adopted by the MRC and domestic governments), ${ }^{185}$ this article can also be seen as a reflection of the Principle of Polluter Pays.

\section{g. Principle of Protection of the International Watercourses and Their Ecosystem}

At this level of international environmental law, there is a general principle called the Principle of Common but Differentiated Responsibilities. This principle consists of two elements: the common responsibility of states to engage in environmental protection, and the differentiated responsibility based on differing circumstances. ${ }^{186}$ Common responsibility hinges on the shared obligation of two or more states to protect specific environmental resources, e.g. shared natural resources. ${ }^{187}$ Within the context of shared water resources, this common responsibility can be translated as a common responsibility to protect the shared water resources, which must also take into account relevant elements, such as the balance of the entire ecosystem.

According to the Agenda 21, which affords freshwater a vital position in the ecosystem, the ecosystem approach to protecting freshwater resources is necessary. ${ }^{188}$ Initially, efforts to protect freshwater emphasized the effects of pollution on water in rivers, lakes, or aquifers, but experts are now convinced that it is essential to protect

\footnotetext{
${ }^{184}$ The 1995 Mekong Agreement (n 138) art 8.

185 The 1995 Mekong Agreement (n 138) art 34, 35.

${ }^{186}$ Sands, Peel, Fabra and MacKenzie (n 156) 233.

${ }^{187}$ Sands, Peel, Fabra and MacKenzie (n 156) 234.

${ }^{188}$ McCaffrey (n 160) 382.
} 
the entire watercourse ecosystem. ${ }^{189}$ This principle has been endorsed by many international instruments, such as the 1992 Helsinki Convention, the 1994 Convention on Cooperation for the Protection and Sustainable Use of the Danube River, as well as the 1995 Mekong Agreement.

Finally, this principle is generally reflected in Article 3 of the Mekong agreement, which mandates that riparian states shall "protect the environment, natural resources, aquatic life and conditions, and ecological balance of the Mekong River Basin from pollution or other harmful effects", as well as in Article 7, which mentions the "ecological balance of the river system" and thereby the protection of the entire Mekong River ecosystem.

\subsubsection{Institutional and Procedural Provisions: Introduction of the Mekong}

\section{River Commission}

The MRC is the only intergovernmental organization that works with four lower Mekong River basin countries on the management of the shared water resources and the sustainable development of the Mekong River basin. ${ }^{190}$ It is a regional body governed by water and environment ministers from the four countries and aims to develop the Mekong waters in the most efficient way while mutually benefitting all member states and minimizing the harmful impact on people and the environment in the Lower Mekong basin. ${ }^{191}$ Additionally, the MRC provides technical support and basin-wide perspectives to the member states, and is also important for regional decision-making and the execution of policies, which promotes sustainable development and poverty reduction. ${ }^{192}$

\subsection{Legal Personality}

The 1995 Mekong Agreement states: "The institutional framework for cooperation in the Mekong River Basin under this Agreement shall be called the Mekong River Commission and shall, for the purpose of the exercise of its functions, enjoy the status of an international body, including entering into agreements and obligations with the

\footnotetext{
${ }^{189}$ McCaffrey (n 160) 382-383.

${ }^{190}$ MRC, 'About MRC' (Official Website of the MRC) < http://www.mrcmekong.org/about-mrc/> accessed 02 October 2016.

191 Ibid.

${ }^{192} \operatorname{MRC}$ (n 190).
} 
donor or international community." 193 This means that the MRC shall assume all of the assets, rights and obligations of the Mekong Committee/Interim Mekong Committee and Mekong Secretariat. ${ }^{194}$ Simultaneously, these expressions also mean that the MRC is an intergovernmental organization and can be a subject of the international public law base on the extent of the 1995 Mekong Agreement. ${ }^{195196}$

\subsection{Structure of the MRC}

The MRC consists of three bodies: the Council, the Joint Committee, and the Secretariat.

\section{a. Council}

The Council consists of one member from each riparian state at the Ministerial and Cabinet level, who is empowered to make policy decisions based on the authority that accompanies his/her governmental status. ${ }^{197}$ The Chairmanship is rotated once a year. The Council must convene one regular session once a year, and may convene special sessions upon request by one of the member states, or when the council considers a special session necessary. The council can also invite other observers. ${ }^{198}$

The Council makes policies and decisions necessary for implementation of the Mekong Agreement. It approves the rules of procedure, rules of water utilization and inter-basin diversions proposed by the Joint Committee. Additionally, the council also approves the basin development plan, and major component projects and programs. The Council settles disputes and differences referred to it by any Council member, the Joint Committee, or any Member State on matters arising under the Agreement. ${ }^{199}$ The Council shall adopt its own Rules of Procedure and may ask for technical advisory services. Decisions made by the Council shall be unanimously approved by

\footnotetext{
${ }^{193}$ The 1995 Mekong Agreement (n 138) art 11.

194 The 1995 Mekong Agreement (n 138) art 13.

${ }^{195}$ Christian Walter, 'Subjects of International Law', Max Planck Encyclopedia of Public International Law (Fall edn 2009), paragraph 5-6 <http://opil.ouplaw.com/view/10.1093/law:epil/9780199231690/law-9780199231690e1018?rskey=EQWcAt\&result=1\&prd=EPIL > accessed 2 0ctober 2016.

${ }^{196}$ Alina Kaczorowska-Ireland, Public International Law (UK, 5th, Routledge, 2015) 191-194.

197 The 1995 Mekong Agreement (n 138) art 15.

${ }^{198}$ The 1995 Mekong Agreement (n 138) art 16, 17.

${ }^{199}$ The 1995 Mekong Agreement (n 138) art 18.
} 
each member government, except as otherwise provided for in its Rules of Procedure. ${ }^{200}$

\section{b. The Joint Committee}

The Joint Committee consists of one member from each member state at no less than head of department level. The chairmanship and chairperson are rotated once a year. Every year, the joint Committee convenes at least two regular sessions and may convene a special session if it considers one necessary or upon request by a member State. It can also invite observers to its session. ${ }^{201}$

The Joint Committee implements the policies and decisions of the Council and performs any other tasks assigned by the Council. In particular, the Joint Committee also formulates a basin development plan and joint development projects and programs, updates and exchanges information and data necessary for implementation of the Agreement, conducts environmental studies and assessments to maintain the ecological balance of the Mekong River Basin, supervises the Secretariat, and attempts to resolve any disputes that arise during regular sessions of the Council. ${ }^{202}$

The Rules of Procedure of the Joint Committee are approved by the Council. It may form permanent sub-committees or working groups, as well as seek technical advisory services, except as may be provided for in the Council's Rules of Procedure or decisions. ${ }^{203}$

The Joint Committee must prepare and make proposals for approval by the Council when it deals with the Rules for Water Utilization and Inter-Basin Diversions contained in Art. 5 and 6, including but not limited to: "1) establishing the time frame for the wet and dry seasons; 2) establishing the location of hydrological stations, and determining and maintaining the flow level requirements at each station; 3) setting out criteria for determining surplus quantities of water during the dry season on the mainstream; 4) improving upon the mechanism to monitor intra-basin use, and 5) setting up a mechanism to monitor inter-basin diversions from the mainstream." ${ }^{204}$

\footnotetext{
${ }^{200}$ The 1995 Mekong Agreement (n 138) art 19, 20.

${ }^{201}$ The 1995 Mekong Agreement (n 138) art 21, 22, 23.

202 The 1995 Mekong Agreement (n 138) art 24.

${ }^{203}$ The 1995 Mekong Agreement (n 138) art 25.

${ }^{204}$ The 1995 Mekong Agreement (n 138) art 26.
} 
Decisions of the Joint Committee must also be approved unanimously by all members, except as otherwise provided for in its Rules of Procedure. ${ }^{205}$

\section{c. The Secretariat}

The Secretariat is under the supervision of the Joint Committee and provides technical and administrative services to the Council and Joint Committee. The Council decides the location and the structure of the permanent office of the Secretariat. ${ }^{206}$

The Secretariat is responsible for carrying out the decision and tasks assigned by the Council and Joint Committee, providing technical service and financial administration and advice, formulating the annual work program, preparing plans, documents, studies and assessments, assisting the Joint Committee, maintaining databases of information, and preparing for sessions of the Council and Joint Committee. ${ }^{207}$

The CEO of the Secretariat and its terms of references are appointed by the Council and the Joint Committee. The Assistant to the CEO is nominated by the CEO and approved by the Chairman of the Joint Committee. ${ }^{208}$ The number of riparian staff posts is assigned on an equal basis among the Member States. ${ }^{209}$

\subsection{The National Mekong Committee (NMC): An Important Role for} Implementation of the MRC Activities

In addition, each Member State has established a National Mekong Committee (NMC), which is also funded by respective governments ${ }^{210}$, to coordinate MRC's programs at national level. The organizational structure of NMCs varies across Member States. ${ }^{211}$

The NMCs link the MRC Secretariat to national ministers and agencies. ${ }^{212}$ They have functions that include formulation of national Mekong policies, providing

\footnotetext{
${ }^{205}$ The 1995 Mekong Agreement (n 138) art 27.

206 The 1995 Mekong Agreement (n 138) art 28, 29.

207 The 1995 Mekong Agreement (n 138) art 30.

${ }^{208}$ The 1995 Mekong Agreement (n 138) art 31, 32.

${ }^{209}$ The 1995 Mekong Agreement (n 138) art 33.

210 The Water Page, 'Mekong River Commission: A Brief Guide'

<http://www.thewaterpage.com/mrc_notes.htm> accessed 29 September 2016.

${ }^{211}$ International Water Governance, 'Mekong'

<http://www.internationalwatersgovernance.com/mekong.html> accessed 29 September 2016.

${ }^{212}$ Paisly, Weiler and Henshaw (n 18) 54.
} 
coordination services for domestic Mekong activities, ensuring that national priorities are reflected in the programs of the MRC, and liaising with donors. ${ }^{213}$

Although the NMCs play very important roles for implementation of MRC activities, they are not mentioned in the Mekong Agreement. Given their functions, however, the NMCs should have a legal basis in the Mekong Agreement for their existence. Because of this current situation, the relationship between the MRC and the NMCs is also not clear. ${ }^{214}$

\subsection{The Relationship between MRC and Other International Organizations}

Certain international organizations have the right to participate in meetings of the Council and Joint Committee ${ }^{215}$ and have attained observer status. ${ }^{216}$ They are the Asian Development Bank (ADB), the Association of Southeast Asian Nations (ASEAN), the International Union for Conservation of Nature (IUCN), the United Nations Development Programme (UNDP), the United Nations Economic and Social Commission for Asia and the Pacific (UNESCAP) and the World Wide Fund for Nature (WWF). ${ }^{217}$

\subsection{Dispute Resolution}

The MRC holds an important role for resolutions of disputes between two or more member States regarding matters covered by the Mekong Agreement and must make an effort to take the first step towards resolutions. ${ }^{218}$ Both the Council and Joint Committee are empowered to address and resolve disputes, ${ }^{219}$ but only if the concerned parties are satisfied the MRC can put an end to the dispute. If the MRC cannot resolve the dispute in a timely manner, the dispute is to be resolved through the diplomatic channels of the Member States' governments. By mutual agreement,

\footnotetext{
${ }^{213}$ The Water Page, 'Mekong River Commission: A Brief Guide' <http://www.thewaterpage.com/mrc_notes.htm> accessed 29 September 2016. 
the member state governments may resort to third-party mediation, which includes an entity like the World Bank or an individual, as may be mutually agreed upon by the parties. ${ }^{220}$ The contents above also reflect that the MRC is less willing to get arbitration or judicial settlement. ${ }^{221}$

\subsection{Data Information Exchange and Sharing}

Both the Joint Committee and the Secretariat are responsible for general data information sharing and exchange. ${ }^{222}$ The Joint Committee must regularly obtain, update and exchange the information and data necessary to implement this Agreement, and conduct appropriate studies and assessments for the protection of the environment and maintenance of the ecological balance of the Mekong River Basin. The Secretariat must also maintain databases of information. The MRC maintains a hydrologic monitoring network. One or more government agencies from each Member State are responsible for collecting data and providing it to the MRC. The MRC Secretariat gives assistances to those agencies that participate in the maintenance of the network, the improvement of field data collection, and the arrangement of in-service training for staff. ${ }^{223}$

The Council adopted the Procedures for Data and Information Exchange and Sharing (PDIES) on 1st November 2001, at the Council's eighth Meeting in Bangkok, Thailand. ${ }^{224}$ In April 2002, the MRC signed the "Agreement on the Provision of Hydrological Information" with China. According to this agreement, two Chinese Monitoring stations would provide data to assist the MRC's flood-forecasting operation. China has been sharing hydro-meteorological data with the MRC during the flood season since 2002, and in August of 2013 agreed to provide more

\footnotetext{
${ }^{220}$ The 1995 Mekong Agreement (n 138) art 35.

${ }^{221}$ Jing Ma, Keith W. Hipel, Mitali De and Jun Cai, 'Transboundary Water Policies: Assessment, Comparison and Enhancement' (2008) 22/8 Water Resources Management 1069, 1077.

${ }^{222}$ Jonathan Chenoweth, 'International River Basin Management: Data and Information Exchange under International Law and the Case of the Mekong River Basin' (2000) 18/2 Journal of Energy \& Natural Resources Law 142, 155.

223 Ibid.

${ }^{224}$ Procedures for Data and Information Exchange and Sharing [2001] Mekong River Commission $<$ http://www.mrcmekong.org/assets/Publications/policies/Procedures-Data-Info-Exchange-nSharing.pdf > accesses 02 October 2016.
} 
hydrological data to the MRC, which will improve flood forecasting in the Lower Mekong countries. ${ }^{225}$

\subsection{Information Reporting ${ }^{226}$}

Before utilizing the Mekong River water resources, a Member state must meet certain information-reporting requirements. The Mekong Agreement provides three forms of information reporting: notification, prior consultation and agreement.

\section{a. Notification}

The definition of notification can be found in the second chapter of the Mekong Agreement, which states that notification denotes "Timely providing information by a riparian to the Joint Committee on its proposed use of water according to the format, content and procedures set forth in the Rules for Water Utilization and Inter-Basin Diversions under Article 26."227

Pursuant to Article 5 and Article 6 of the Mekong Agreement, when a Member State wants to carry out an intra-basin utilization or inter-basin diversion on the tributaries, including Tonlé Sap, and intra-basin utilization on the mainstream during the wet season, the Notification requirement and procedures need to be applied. ${ }^{228}$ The Notification must include a feasibility study report, an implementation plan, a schedule and all available data. ${ }^{229}$

There are three mechanisms for handling a Notification. First, the National Mekong Committee is responsible for informing the relevant line agencies of the scope, content and form of a Notification, reviewing and checking the Notification, assembling, recording and transmitting the Notification with appropriate documents to the MRC Secretariat for its submission to the Joint Committee and transmission to

\footnotetext{
${ }^{225}$ MRC, 'Mekong River Commission and China boost water data exchange' (Vientiane, 30 August 2013) <http://www.mrcmekong.org/news-and-events/news/mekong-river-commission-and-chinaboost-water-data-exchange/> accessed 29 September 2016.

${ }^{226}$ Procedures for Notification, Prior Consultation and Agreement [2010] Mekong River Commission $<$ http://www.mrcmekong.org/assets/Publications/policies/Procedures-Notification-Prior-ConsultationAgreement.pdf> accesses 02 October 2016.

${ }^{227}$ The 1995 Mekong Agreement (n 138) chapter II Definitions of Terms.

${ }^{228}$ Alistair Rieu-Clarke, 'Notification and Consultation Procedures Under the Mekong Agreement: Insights from the Xayaburi Controversy' (2015) 5 Asian Journal of International Law 143, 148.

${ }^{229}$ PNPCA (n 226) 4.1 and 4.2.
} 
the other NMCs. Second, the Secretariat is responsible for receiving, checking, recording and making files on the Notification, submitting the Notification to the Joint Committee and sending copies to each of the other NMCs, entering the relevant data and information into the MRC Secretariat Data and Information System, as well as placing any comments on the Notification in a file and submitting them to the Joint Committee. Third, the Joint Committee has the responsibility to acknowledge any Notification submitted to it and take note of comments made by Secretariat. ${ }^{230}$ When a Notification has not been provided, the Joint Committee will request that the relevant NMC fulfill its duties/responsibilities. ${ }^{231}$

\section{b. Prior Consultation}

Prior Consultation means: "Timely notification plus additional data and information to the Joint Committee as provided in the Rules for Water Utilization and Inter-Basin Diversion under Article 26, that would allow the other member riparians to discuss and evaluate the impact of the proposed use upon their uses of water and any other effects, which is the basis for arriving at an agreement. Prior consultation is neither a right to veto the use nor unilateral right to use water by any riparian state without taking into account other riparian states' rights." ${ }^{232}$

There are three conditions requiring prior consultation: inter-basin diversion from the mainstream during wet season, intra-basin utilization on the mainstream during the dry season, and inter-basin diversion of the surplus quantity of water during the dry season. ${ }^{233}$ The content of the prior consultation includes the Notification, and additionally requests the notifying state to provide technical data and information on its proposed use of water for an evaluation of impacts by the other member states. ${ }^{234}$

The NMCs and all the three bodies of the MRC are responsible for handling the prior consultation. ${ }^{235}$ Firstly, the NMCs have the responsibility to inform the relevant line agencies of the scope, content and form required for prior consultation, receiving, reviewing and checking documentation for any prior consultation, assembling and

\footnotetext{
${ }^{230}$ PNPCA (n 226) 4.3.

${ }^{231}$ PNPCA (n 226) 4.6.

${ }^{232}$ The 1995 Mekong Agreement (n 123) chapter II Definitions of Terms.

${ }^{233}$ Rieu-Clarke (n 228) 149.

${ }^{234}$ PNPCA (n 226) 5.2.

${ }^{235}$ PNPCA (n 226) 5.3.
} 
transmitting the proposal to the MRC Secretariat for submission to the Joint Committee and transmission to the other NMCs, facilitating any consultations, presentations, evaluations or site visits as requested by the Joint Committee for the proposed use, and recording and transmitting copies of any comments or response received from the Secretariat to the respective line agencies or parties. ${ }^{236}$ Secondly, the MRC Secretariat takes the responsibility to receive, check for completeness, record and make a file of the documents for prior consultation, to submit the prior consultation to the Joint Committee and send a copy to the other NMCs, to review, analyze and provide technical advice to the Joint Committee, to supply available additional data and information and facilitate the meetings as requested by member State(s) concerned, to provide available technical support, and to enter the relevant data and information into the MRC Data and Information System. ${ }^{237}$ Thirdly, the Joint Committee takes on the role of acknowledging and reviewing documents for prior consultation, reviewing comments made by any of the member States, carrying out consultation with the support of the Secretariat, setting up a Working Group to assist in the prior consultation process, making an effort to address matters during the process of prior consultation, and finally, verifying and unanimously confirming the availability of a surplus quantity of water on the mainstream. ${ }^{238}$ The MRC Council has related functions based on the Mekong Agreement. ${ }^{239240}$

Documents for prior consultation are submitted by the NMC to the Joint Committee through the Secretariat. The Secretariat must transmit copies of the documents to other member State(s) for their evaluation and reply. Upon receiving the documents, the other member(s) should evaluate the proposed utilization and reply to the Joint Committee through the Secretariat. If necessary, the notified State(s) may request additional information, a consultation or presentation, and/or a field-visit to the project site to evaluate the possible impacts of the proposed use and other effects. During the evaluation process period, the notifying State(s) must provide available data and information and facilitate an appropriate evaluation. If necessary, the Joint Committee may direct the Secretariat or appoint a working group or technical

\footnotetext{
${ }^{236}$ PNPCA (n 226) 5.3.1.

${ }^{237}$ PNPCA (n 226) 5.3.2.

${ }^{238}$ PNPCA (n 226) 5.3.3.

${ }^{239}$ PNPCA (n 226) 5.3.4.

${ }^{240}$ The 1995 Mekong Agreement (n 138) art 18.
} 
advisory team to provide assistance. The Joint Committee shall also aim to arrive at an agreement and issue a decision for proposed utilization. ${ }^{241}$ The notifying State(s) must not implement the proposed utilization without giving the other member states the opportunity to discuss and evaluate the proposal. The Joint Committee must take note of replies and record them. ${ }^{242}$ Importantly, the Mekong Agreement specifically states that this consultation would not give any riparian a right to veto the use of water. ${ }^{243}$ Therefore, the MRC should also take into account the balance between interests of member states. ${ }^{244}$

The timeframe for prior consultation is six months, starting from the date when documents on prior consultation were received, although the Joint Committee may also extend this period. In cases where the documents required for prior consultation have not been provided, the Joint Committee will request the relevant NMC to fulfill its duties. $^{245}$

\section{c. Agreement}

Pursuant to the Second Chapter of the Mekong Agreement, the "Agreement" means: "A decision of the Joint Committee resulting from prior consultation and evaluation on any Proposed use for inter-basin diversions during the wet season from the mainstream as well as for intra-basin use or inter-basin diversions of these waters during the dry season. The objective of this agreement is to achieve an optimum use and prevention of waste of the waters through a dynamic and practical consensus in conformity with the Rules for Water Utilization and Inter-Basin Diversions set forth in Article 26."${ }^{246}$

During the dry season, any inter-basin diversion project must be approved by the Joint Committee through a specific agreement, which must be signed by all members of the Joint Committee after the terms and conditions have been agreed upon. "The process initially would be that the country or countries would notify the MRC Joint

\footnotetext{
${ }^{241}$ PNPCA (n 226) 5.4.

242 Ibid.

${ }^{243}$ Rieu-Clarke (n 228) 149.

${ }^{244}$ Ibid.

${ }^{245}$ PNPCA (n 226) 5.5, 5.6.

${ }^{246}$ The 1995 Mekong Agreement (n 138) chapter II Definitions of Terms.
} 
Committee to initiate, on a case by case basis, the consultation process leading to a specific agreement." 247

\subsection{Funding and Financing}

The budget of the MRC is drawn up by the Joint Committee and approved by the Council. The budget consists of contributions from member states, the international community (donor countries) and other sources. The member States contribute to the MRC's operating or administrative budget on an equal basis; however, the Council may change the member contribution requirements based on extraordinary expenditures that exceed the planned budget. ${ }^{248}$ There is also an annual Donor Consultative Group meeting for the MRC to carry out formal consultation with the donor community. ${ }^{249}$ In 2010, by signing the Hua Hin Declaration, the member states committed to continuously financing the MRC until $2030 .{ }^{250}$

\subsubsection{The Complex Relationship within the Mekong Water Regime}

\subsubsection{The Relationship between MRC and Domestic Interests}

Although the Mekong water regime is a trans-boundary water regime, it also reflects national-level interests to some extent. As detailed in Chapter 1, the four member states in the Mekong River basin have different objectives according to their national interests. Additionally, China as the upper stream country would have interest in hydropower and navigation, which could also affect the relationship between China and other lower stream countries. ${ }^{251}$ Even though these objectives are different, they

\footnotetext{
${ }^{247}$ Guidelines on Implementation of the Procedures for Notification, Prior Consultation and Agreement [2005] Mekong River Commission, I. C.

<http://www.mrcmekong.org/assets/Publications/policies/Guidelines-on-implementation-of-the-

PNPCA.pdf $>$ accessed 29 September 2016.

2481995 Mekong Agreement (n 138) art 14.

${ }^{249}$ International Water Governance, 'Mekong'

<http://www.internationalwatersgovernance.com/mekong.html> accessed 29 September 2016.

${ }^{250}$ MRC Hua Hin Declaration [2010] Mekong River Commission, Way Ahead

<http://www.mrcmekong.org/assets/Publications/Events/MRCSummit2010/MRC-Hua-Hin-

Declaration-05-Apr-10.pdf> accessed 26 October 2016.

${ }^{251}$ Philip Hirsch, Kurt Mørck Jensen with Ben Boer, Naomi Carrard Stephen, Fitz Gerald, Rosemary

Lyster, 'National Interest and Trans-boundary Water Governance in the Mekong'
} 
all tend to focus more on economic benefits that also affect the direction of the water regime's development. ${ }^{252}$ As the only specific international organization for water management of the Mekong River basin and therefore the cornerstone of this relationship, the MRC must be discussed here.

There is a general expectation of the MRC that it should serve the broad public interest in the Mekong river basin. This expectation also includes protecting of the interests of the weak and poor individuals who live along the river. The civil society of the countries in the Mekong region also treats this expectation very seriously, and many studies focused on this issue have been carried out. But the results of these studies show that the MRC cannot fulfill these expectations. There are some specific reasons for this: Firstly, the expression and representation of national interests in the Mekong region are very fragmented and closely equated with sectorial interests, and are frequently related to pecuniary interests. ${ }^{253}$ In the political system, the control and the disposition of the water resources in the Mekong river basin have not received enough attention. The diversity of interests in the water and river basin management thus become a complexity that civil society must deal with. ${ }^{254}$ Secondly, the civil society in this region is itself extremely diverse. In Thailand, the civil society is well developed, but in other states, such as Vietnam and Laos, the civil society is highly constrained. ${ }^{255}$ In Burma, there is almost no expectation regarding human rights and other civic groups outside the national borders. ${ }^{256}$ This situation also brings difficulties to the MRC, and reflects the different degrees of political space for expression of alternative views, and claiming of different interests, among the six riparian countries. $^{257}$ Thirdly, the relationship between civil society and the MRC is positive. Civil society groups find that the MRC is a distant organization, and think that the $\mathrm{MRC}$ is reluctant to protect the interests of weak or weaker member states: "All the

(2006) Australian Mekong Resource Centre at The University of Sydney in collaboration with Danish International Development Assistance, 46 <http://sydney.edu.au/mekong/documents/mekwatgov_mainreport.pdf> accessed 29 September 2016.

${ }^{252}$ Hirsch, Jensen with Boer, Stephan, Gerald and Lyster (n 251) 47.

${ }^{253}$ Hirsch, Jensen with Boer, Stephan, Gerald and Lyster (n 251) 49.

${ }^{254}$ Ibid.

${ }^{255}$ Hirsch, Jensen with Boer, Stephan, Gerald and Lyster (n 251) 50.

${ }^{256}$ Ibid.

${ }^{257}$ Hirsch, Jensen with Boer, Stephan, Gerald and Lyster (n 251) 49. 
civil society groups feel that the MRC should adopt a pro-active and regulatory role in river governance rather than carrying out projects conceived and funded by external interests." ${ }^{258}$

In fact, the MRC represents more the interests of the bureaucracy to whom all four governments have delegated responsibility for Mekong affairs. ${ }^{259}$ At the political level, the MRC has also not gained enough attention, because the foundation of its establishment is river and water recourses. The member states have little sense of what the future holds for the river based on a "soft" and ambiguous "Mekong Spirit Agreement". The community interests should be represented by the NMC, but in practice "it is difficult for a community to know where to go, to obtain a hearing, and nearly impossible to have their concerns seriously raised through these administrative structures" ${ }^{\prime 260}$.

\subsubsection{The Relationship with China}

China is located in the uppermost region of the Mekong River Basin and is home to $16 \%$ of the flows in the Mekong River; however, because it is not a member state of the Mekong Agreement, it therefore could not to be a member of the MRC either. In 1997, China voted against the UNWC as one of the only four countries against this Convention. One year after the establishment of the Mekong Agreement, China became an official "dialogue partner", and has demonstrated an increasing commitment to cooperation, including sharing more data and information on the status of upstream developments and joint capacity-building activities. ${ }^{261}$ The relationship between the MRC and China was strengthened in 2002 with the signing of a Memorandum of Understanding on the provision of daily river flows and rainfall data from two monitoring stations in China's Yunnan Province during the wet season, which helps improve the MRC's regional daily forecast of downstream water levels at key points on the Mekong River, therefore saving lives and decreasing property damage during the flood season. ${ }^{262}$ Since June 2004, 24-hourly water level and 12 -

\footnotetext{
${ }^{258}$ Hirsch, Jensen with Boer, Stephan, Gerald and Lyster (n 251) 51.

${ }^{259}$ Hirsch, Jensen with Boer, Stephan, Gerald and Lyster (n 251) 52.

${ }^{260}$ Hirsch, Jensen with Boer, Stephan, Gerald and Lyster (n 251) 54.

${ }^{261}$ MRC, 'Upstream Partners' (Official Website of the MRC) < http://www.mrcmekong.org/aboutmrc/upstream-partners/> accessed 29 September 2016.

${ }^{262}$ Ibid.
} 
hourly rainfall data have been sent daily from China to the MRC for flood forecasting purposes. In January 2006, the MRC Secretariat began supplying China with monthly flow data from hydrological stations in Chiang Saen, Thailand and Stung Treng, Cambodia. ${ }^{263}$ In 2008, an agreement on the provision of hydrological information was signed to renew the previous data sharing agreement on flood season water flows signed in 2002. A delegation of Lower Mekong government officials and the MRC Secretariat visited dams in China in June of 2010 for the first time and also discussed issues of future cooperation between the MRC and China. In November of 2014, China reaffirmed its commitments to continue and enhance cooperation with the MRC.

Based on the existing cooperation, the understanding and communication between China and other Lower Mekong countries could be strengthened. In this sense, all of the member states are willing to allow China to join the Mekong water regime. Despite this fact, China is still not willing to join, because there are also some disadvantages from China's standpoint: Firstly, joining the Mekong water regime would put some limitations on Chinese domestic exploitation of water resources and hydropower ${ }^{264}$ Secondly, China is also afraid of becoming a minority in the Mekong River Basin. Most members of the Mekong are downstream countries, and the Mekong Agreement gives preference to the downstream countries. Thirdly, China holds the upper stream position not only in the case of the Mekong River, but also for many other international rivers. China thus fears that membership in the Mekong water regime would cause downstream countries from other international rivers to make similar demands. In addition to these reasons, the different political background of China and some historical reasons have also affected China's decisions on the Mekong Agreement. ${ }^{265}$ China therefore wants to continue to be a mere dialogue partner of the MRC, and to keep developing its bilateral relationship with other riparian countries in the Mekong River Basin.

\footnotetext{
${ }^{263}$ MRC, 'MRC, China and Myanmar cooperate on shared Mekong resources' (Official Website of the MRC) <http://www.mrcmekong.org/news-and-events/news/mrc-china-and-myanmar-cooperate-onshared-mekong-resources/> accessed 29 September 2016.

${ }^{264}$ Onishi (n 13) 529.

${ }^{265}$ Yuanling Xu, 'Research on the China-ASEAN Cooperative Legal Regime for the International River Protection' (DPhil thesis, University of Chongqing 2011) 26.
} 
"It has been suggested that one of the fundamental requirements for an international regime is its inclusiveness, implying the participation of all significant states." 266 Although there has already been a certain amount of technical cooperation between the MRC and China, the impacts on the effectiveness of the Mekong water regime caused by China's refusal to join the regime must still be given serious consideration. $^{267}$

\subsubsection{The Relationship with Donors}

After the 1995 Mekong Agreement was signed, many donors were interested in providing assistance to the Mekong water regime through technical and financial collaborations. The MRC calls donors "development partners", and these include bilateral donors (Australia, Belgium, Denmark, Finland, France, Germany, Japan, Luxembourg, New Zealand, Sweden, Switzerland, and The Netherlands) and multilateral donors (the European Union, the United States, and the World Bank). ${ }^{268}$ Some of the donors focus more on the core priority areas closely related to water utilization and environmental conservation; other donors focus more on the sector programs. ${ }^{269}$ Most of the MRC's budget depends on donor funding, as the contributions from the member countries cover only $10 \%$ of the budget. ${ }^{270}$

The donors have not been overly interested in the MRC's political nature or water governance at the political level. They treat the MRC more as a "technical-managerial arrangement for IWRM, environmental protection, or specific sector developments". ${ }^{271}$ A number of relative programs are managed by the MRC Secretariat, and are funded by one or more donors. In fact, however, the MRC does not have enough power to decide the direction of these programs, because these programs are funded by donors and actually "donor-driven". ${ }^{272} \mathrm{MRC}$ has therefore

\footnotetext{
${ }^{266}$ Ellen Bruzelius Backer, 'Paper Tiger Meets White Elephant?' (2006) The Fridtjof Nansen Institute Report 15/2006 < http://www.fni.no/pdf/FNI-R1506.pdf> accessed 29 September 2016.

${ }^{267}$ Backer (n 266) 65.

${ }^{268}$ MRC, 'Development Partners \& Partner Organisations' (Official Website of the MRC)

<http://www.mrcmekong.org/about-mrc/development-partners-and-partner-organisations/> accessed 29 September 2016.

${ }^{269}$ Hirsch, Jensen with Boer, Stephan, Gerald and Lyster (n 251) 90.

${ }^{270}$ Ibid.

${ }^{271}$ Hirsch, Jensen with Boer, Stephan, Gerald and Lyster (n 251) 93.

${ }^{272}$ Hirsch, Jensen with Boer, Stephan, Gerald and Lyster (n 251) 92.
} 
become a very reactive organization, and its dependence on donor projects has also become its obvious weakness. ${ }^{273}$ There is even comment said that the MRC is only "a vehicle for managing external donor grants rather than a multilateral political water governance organization". 274

A recent statement made at the informal donor meeting on $24^{\text {th }}$ June 2015 also reflects this relationship. The donors mentioned that they would not provide funding without clarity on the issues of "future MRC's organizational structure, staffing, basket fund operations oversight and the cost sharing formula between Member Countries"275, or without the approved Basin Strategic Plan. On the one hand, the Council and the Joint Committee hold the right to approve the Basin Strategic Plan, but on the other hand, the MRC never say "no" to donor projects. ${ }^{276}$ So the "approved Strategic Plan" mentioned above is actually decided by the donors.

To improve the relationship between donors and the MRC, there have been some suggestions for its future development. Firstly, the coordination between the donors is not easy, therefore some donors suggested that a lead donor needs to be selected as coordinator to reduce some of the transactional costs. ${ }^{277}$ Secondly, the donors should establish a common platform for communication with the MRC based on giving deeper understanding to the MRC and showing more commitment in donors' engagement with the MRC. ${ }^{278}$ Because many different projects are being funded and some of these projects are not related to MRC's core functions, the donors have a fragmented approach to the MRC, This platform could, to some extent, solve the problems caused by the donors' fragmented approach. ${ }^{279}$ Thirdly, the sustainability and the effectiveness of this relationship should become a critical issue for this relationship. The donors have already noticed this point and want to promote the reform of the organizational structure of the MRC. The Prior Consultation process

\footnotetext{
${ }^{273}$ Ibid.

${ }^{274}$ Paisly, Weiler and Henshaw (n 18) 56.

2015/> accessed 29 September 2016.

${ }^{276}$ Hirsch, Jensen with Boer, Stephan, Gerald and Lyster (n 251) 92.

${ }^{277}$ Hirsch, Jensen with Boer, Stephan, Gerald and Lyster (n 251) 107.

${ }^{278}$ Hirsch, Jensen with Boer, Stephan, Gerald and Lyster (n 251) 108.

${ }^{279}$ Ibid.
}

${ }^{275}$ MRC, 'Joint Development Partner Statement, 24 June 2015' (Vientiane, 24 June 2015)

<http://www.mrcmekong.org/news-and-events/speeches/joint-development-partner-statement-24-june- 
also becomes a focus in this context, given its relationship to both the effectiveness of the cooperation and the sustainable development of the river basin. ${ }^{280}$

\subsubsection{Assessment of the 1995 Mekong Agreement and the MRC}

In practice, using treaties for regulating international watercourse and management of shared water resources brings a series of advantages. ${ }^{281}$ Treaties can strengthen the stability of regional relations and create the premise of establishment of the joint management institution, which facilitates the benefits sharing and cooperation between the riparian countries. ${ }^{282}$ "Treaties permit states to define with great specificity the rules governing all aspects of their relations" on the international watercourses and shared water management. ${ }^{283}$ As a regional agreement focuses on international watercourse and shared water resources, the 1995 Mekong Agreement also presents the advantages above.

There are two obvious characteristics that can be gleaned from the 1995 Mekong Agreement. Firstly, the principles of the Mekong Agreement, reflected in Art.1-10, are very broad. ${ }^{284}$ In other words, because the principles expressing the general spirit of the Mekong Agreement are very vague, they don't contain enough guidance to put the Mekong Agreement into concrete operation. However, this fact also allows these principles be utilized in many different aspects and not be limited to one particular field. Secondly, the 1995 Mekong Agreement provides a flexible framework and a continuous dialogue and negotiation process. ${ }^{285}$ For example, the 1995 Mekong Agreement tries to prevent and mitigate disputes between member states by Notification, Prior Consultation and Agreement and other procedures. However, it

\footnotetext{
${ }^{280}$ MRC, 'Joint Development Partner Statement, 24 June 2015' (Vientiane, 24 June 2015)

$<$ http://www.mrcmekong.org/news-and-events/speeches/joint-development-partner-statement-24-june2015/> accessed 29 September 2016.

${ }^{281}$ Stephen C McCaffrey, 'The Need for Flexibility in Fresh Water Treaty Regimes' (2003) 27 Natural Resources Forum 156, 157.

282 Ibid.

${ }^{283}$ Ibid

${ }^{284}$ Sokhem Pech, 'UN Watercourses Convention and Greater Mekong Sub-region' (2011) UNWC's

Global Relevance: South and East Asia, 29

<http://www.unwatercoursesconvention.org/images/2012/10/Mekong-and-UNWC.pdf> accessed 29

September 2016.

${ }^{285}$ Pech (n 284) 29.
} 
does not provide peaceful means, such as international courts of justice or binding arbitration, to resolve conflicts, stating only that the MRC "shall firstly make every effort to resolve" the dispute ${ }^{286}$, but, in Article 35, that the conflicts can be resolved by bilateral agreement or by mediation through another party or entity, which has been agreed mutually. ${ }^{287}$ These two main characteristics make the 1995 Mekong Agreement be very ambiguous and not powerful enough, producing a series of related drawbacks.

\subsubsection{Assessment of the Substantive Aspect}

Some critical voices assert that, as the key legal instrument for the water legal regime of the Mekong River, the 1995 Mekong Agreement is too "soft" and too "hortatory", and relies too heavily on informal procedures, such as "informal negotiation, the nonlegal expression of sovereign prerogatives, national 'resource sovereignty', geopolitical interests, and non-binding, consultative decision-making". ${ }^{288}$ The few harder provisions from this Agreement have not been utilized. ${ }^{289}$ Even though the UN Watercourse Convention had already entered into force, only Vietnam signed it. The Espoo convention, which is in respect of trans-boundary EIA, is in the situation that no countries in the Mekong River basin signed it. Therefore, the expectation on governance by international law could not be well fulfilled. ${ }^{290}$ According to this "softness", the Mekong Agreement has become very weak facing the heavy burden of governing the water resources in Mekong River.

While the perception above criticized the softness of the 1995 Mekong Agreement, others maintain that the flexibility of the treaties, which could also be treated as a kind of softness, is necessary for the field of international watercourse and shared water resources. ${ }^{291}$ The circumstances of international watercourses change constantly based on numerous elements, such as seasonal elements, climate change, natural catastrophe, abnormal weather condition and so forth. Most of the watercourse treaties have

\footnotetext{
${ }^{286}$ The 1995 Mekong Agreement (n 138) art 34.

${ }^{287}$ Pech (n 284) 30.

${ }^{288}$ Fleur E. Johns, Ben Saul, Philip Hirsch, Tim Stephens, Ben Boer, 'Law and the Mekong River

Basin: A Socio-Legal Research Agenda on the Role of Hard and soft Law in Regulating

Transboundary Water Resources' (2010) 11 Melbourne Journal of International Law 1, 6.

${ }^{289}$ Johns, Saul, Hirsch, Stephens and Boer (n 288) 5.

290 Ibid.

${ }^{291}$ McCaffrey (n 281) 157.
} 
already taken seasonal elements into consideration, but the attention on other elements is not always sufficient. ${ }^{292}$ And in fact it is very difficult for a state to escape its obligations based only on changed conditions. ${ }^{293}$ Therefore, the flexibility of the treaties with respect to international watercourses is necessary and can provide a reasonable way for parties to respond to the changed circumstances and not to terminate or suspend the treaties. ${ }^{294}$ There are also several ways to establish the flexibility of treaties, and the most important means is the establishment of joint institutions that hold the authority to respond to the changed conditions. ${ }^{295}$

At the level of international law, soft law is normally not legally binding, but nevertheless has "quasi-legal force". It can establish a "self-contained regime", and embodies the party's intention effectively and flexibly. ${ }^{296}$ It provides a more tolerant space for the development of the international law. ${ }^{297}$ Nevertheless, in the context given, the value of the softness and the hardness is different. In the field of transboundary water management, the "informal, non-binding norms" are more effective and less threatening. ${ }^{298}$ Therefore, the softness of the 1995 Mekong Agreement is not always adverse, and the MRC as the joint institution should also conform to the requirement of flexibility. The "softness" should be considered a necessary element in substantive aspects of international water regimes. There are different levels of "softness"; therefore, "softness" still needs to be considered very carefully in practice. The softness of the hard law and the hardness of the soft law should both not be underestimated, and to connect softness with hardness together in a rational way is an appropriate and wise choice for transboundary water resources' management. ${ }^{299}$

The implementation of the 1995 Mekong Agreement is also an important aspect. Even though all of the lower stream states very quickly ratified the Mekong Agreement, the implementation of this agreement's objectives is still very slow and gives people the

\footnotetext{
292 Ibid.

${ }^{293}$ McCaffrey (n 281) 159.

${ }^{294}$ Ibid.

${ }^{295}$ McCaffrey (n 281) 159-161.

${ }^{296}$ Johns, Saul, Hirsch, Stephens and Boer (n 288) 9.

297 Ibid.

298 Johns, Saul, Hirsch, Stephens and Boer (n 288) 10.

${ }^{299}$ Johns, Saul, Hirsch, Stephens and Boer (n 288) 10-11.
} 
impression that the effectiveness of this agreement is not sufficient. ${ }^{300}$ For instance, the BDP, which had already been outlined in 1995, finally commenced operations in 2001. ${ }^{301}$ In the Mekong Agreement, there is also no expression for Commission's decisions' legal enforcement. ${ }^{302}$ In fact, this problem also caused the MRC to become very reactive and incapable of producing enough tangible results for the implementation of the objectives. ${ }^{303}$

At level of national legislation, there are hardly any references to implementations of the 1995 Mekong Agreement. ${ }^{304}$ There are even National Mekong Committees (NMCs) that are responsible for the connection of the national level and the MRC. And the 2004 Annual Report of the MRC also mentioned that the MRC should coordinate its programs at the domestic level and proves the connection between the Secretariat and the national ministries and other related agencies. ${ }^{305}$ But still, the situation of the implementation at the national level is not so bright. The reason for this situation can be partly found in the reality that the legislation of the environment protection and natural resources conservation at the national level is not that welldeveloped either. The improvement of this situation must also be taken into consideration and will be discussed in the fourth Chapter.

\subsubsection{Assessment of the Institutional and Procedural Aspect}

Based on the softness of the Mekong Agreement and its "Mekong Spirit", the MRC is also criticized as an ineffective organization that brings little tangible results for economic development in Mekong River basin. ${ }^{306}$ The enforcement of the Basin Development Plan (BDP), which is treated as the "primary rationale for the institutional existence of the MRC" 307 by Mekong governments and international donors, is very slow and has always been delayed in the second phase. The subjects of the BDP are also criticized as not appropriate to the real needs and aspirations of the

\footnotetext{
${ }^{300}$ Paisly, Weiler and Henshaw (n 18) 56.

${ }^{301}$ Radosevich, Cogels, Dore, Metzger, Sokhem, Curlier and Etmanski (n 65) 24.

${ }^{302}$ Ma, W. Hipel, De and Cai (n 221) 1077.

303 Ibid.

${ }^{304}$ Hirsch, Jensen with Boer, Stephan, Gerald and Lyster (n 251) 33.

${ }^{305}$ Hirsch, Jensen with Boer, Stephan, Gerald and Lyster (n 251) 34.

${ }^{306}$ Paisly, Weiler and Henshaw (n 18) 55.

${ }^{307}$ Ibid.
} 
member countries. ${ }^{308}$ Furthermore, the procedures of the MRC are restraining and have caused a series of difficulties when BDP faced the issue of mainstream dams. ${ }^{309}$ There is also discussion on the reasons for the MRC's ineffectiveness. Firstly, the MRC is lacking a regulatory authority. The MRC has no supra-national authority based on the Mekong Agreement and its authority has been limited by which member countries signed, but the public and civil society did not understand this situation very well. ${ }^{310}$ Secondly, the donors also misunderstood the MRC's lack of authority and had high expectations of the MRC for action beyond national interests; this caused some donor assistance to be wasted and also decreased the effectiveness of the assistance. ${ }^{311}$ Thirdly, the governance of NMC and the Joint Committee is narrow, often arbitrary, and uncommitted at senior political levels. This forced the member countries to rely on their own means to deal with related interests. The functions of the MRC will also be affected by these "own means", and the diversity of the interest also gets lost in this situation. Fourthly, as the MRC's CEO the Secretariat has a very ambiguous leadership role, and can hardly provide independent advice based on river basin science. In consequence, the work of the Joint Committee and the Council is affected as well. ${ }^{312}$

The institutional structure of the MRC also causes difficulties in the operation of the MRC. The donors' policies too often affect the decisions of the Secretariat, and this also reflects the competition between donors' interests by Secretariat and the interests of the member countries by the Council and the Joint Committee. On the one hand, the Secretariat convinces the Joint Committee and the Council that the priority of the projects funding will not trump the member countries' development goal. On the other hand, the interests of the donors and the member countries are often different. ${ }^{313}$ For instance, in the period between 2004-2007, there was an orientation of the MRC towards economic benefits and investment facilitation, which was welcomed by member countries as well as their potential partner, China. But the donors objected to this orientation and the subsequent increased cooperation with China and took

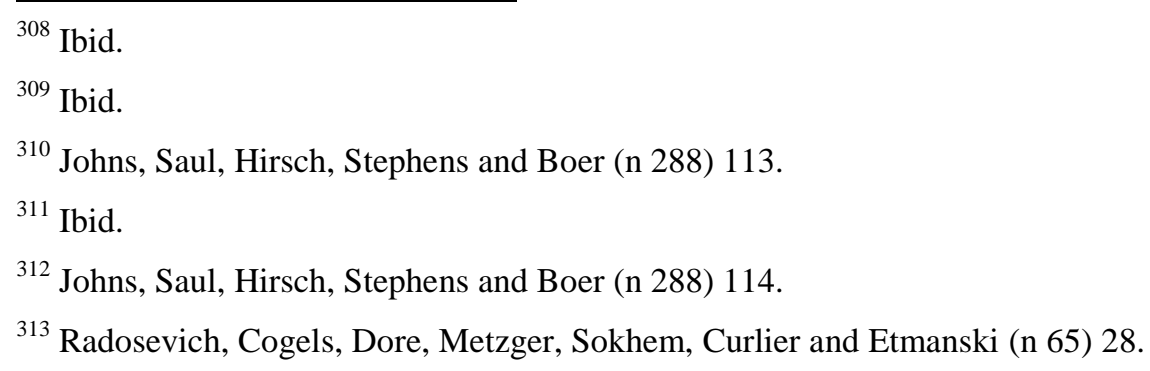


measures to ensure this did not happen. ${ }^{314}$ Under this pressure of losing donor money, the MRC complied with the donor's objections and lost its reputation as an independent organization, eventually being criticized as an "NGO-type of Environment Protection Agency in the hands of the donor community", 315 and cannot be a regulatory body. ${ }^{316}$

Conversely, the MRC has also enjoyed a certain number of successes. Firstly, it promotes the development of the Water Utilization Programme, and according to this Programme it improved the ability to impact assessments of proposed development, good working relationships, and the institutional growth of various multilateral working groups. ${ }^{317}$ Secondly, the MRC's ability to generate data and information has improved. This data and information focuses not only on water quality, but also on flood forecasting, technical databases, hydropower databases and so forth. Thirdly, thanks to the improvement of water monitoring, the environmental awareness of the local authorities and riparian agencies has also increased. For instance, the Fisheries Programme of the MRC has taken sustainable development into consideration and started an extensive research program for supplying related information. ${ }^{318}$ In summary, although there are some disadvantages, the MRC is in fact still an important contributor to peace and stability, and to the river water resources sustainable management, development and protection in this region.

\subsection{Summary of this Chapter}

This Chapter has introduced the Mekong water regime at different levels and in different aspects. Firstly, it introduced the legal basis for the Mekong water regime at different levels. At the international stage, there are a series of related instruments for trans-boundary water resources management, but not all of these instruments can be utilized for the Mekong water regime. The 1997 UNWC, which entered into force on 17th August of 2014 based on Vietnam's ratification, can be seen as a relevant tool for this regime. In addition to the instruments at the international level, there are also specific regional instruments for trans-boundary water resources management and

\footnotetext{
${ }^{314}$ Radosevich, Cogels, Dore, Metzger, Sokhem, Curlier and Etmanski (n 65) 28.

${ }^{315}$ Radosevich, Cogels, Dore, Metzger, Sokhem, Curlier and Etmanski (n 65) 28-29.

${ }^{316}$ Boer, Hirsch, Johns, Saul and Scurrah (n 11) 104.

${ }^{317}$ Radosevich, Cogels, Dore, Metzger, Sokhem, Curlier and Etmanski (n 65) 29.

${ }^{318}$ Radosevich, Cogels, Dore, Metzger, Sokhem, Curlier and Etmanski (n 65) 29-30.
} 
protection, namely the 1995 Mekong Agreement. Based on this Agreement, the regional institution for Mekong River's water resources management and protection was established. The 1995 Mekong Agreement and the MRC's work are at the core of the Mekong water regime. Additionally, there are also some relative initiatives for the Mekong water regime established for economic or other purposes, and based on other regional organization or arrangements. These initiatives may originate from nonenvironmental organization or agreements, yet their contents are closely associated with the water resources management of the Mekong River basin. Therefore, these relative initiatives can also produce certain influences for the development of the Mekong water regime.

The second part of this Chapter analyzed the core legal basis and institution of the Mekong water regime in detail. The historical background introduces the evolution of the Mekong water regime, and introduced three different historical phases of the Mekong water regime. The historical background is followed by an explicit introduction to the Mekong Agreement and the MRC. This agreement and the MRC are the core legal basis and the core institution of the Mekong water regime. After the aim of this agreement was expressed, the introduction was divided into two portions: the substantive provisions and the institutional and procedural provisions. The substantive part expresses the main contents and principles of the Agreement. The structure and objectives of the MRC are explained in the institutional and procedural part. After explicit illustration of the 1995 Mekong Agreement and the MRC, the complexity of the relationship in this water regime was discussed. The relationship between the MRC and domestic interest, the MRC and China, as well as the relationship between the MRC and donors were analyzed to give us a more comprehensive view when considering the Mekong water regime's current situation and directions of its future development. Finally, the assessment of the 1995 Mekong Agreement and its institution, the MRC, were expounded upon in this chapter, which focused on the drawbacks of the 1995 Mekong Agreement and the MRC and also analyzed the reasons behind these drawbacks. This assessment can be seen as an important basis for clarifying the direction of future improvements to the Mekong water regime. 


\section{Chapter 3. Functional Comparison of the International Legal Water}

\section{Regimes in the Mekong River Basin and the Rhine River Basin}

The former chapter shows us a systematic picture of the Mekong water regime and also gives the author a new angle to analyze this regime in depth, which is to figure out what kinds of functions the Mekong water regime has. The analysis on these functions is quite relative to the implementation stage of this regime. It can also help researchers to understand the real aim and needs for sustainable development of the Mekong Region. As a famous well-developed water regime, the Rhine regime plays a major role in the water resources protection and also related ecosystem protection in the Rhine river basin. It also has various functions bases on the work of its institution, namely the Rhine River Commission. A functional comparison between these two regimes is a way to clarify the reasons for some essential differences between them. Additionally, this chapter is also a critical basis for the subsequent discussion on the improvement of the Mekong water regime.

\subsection{Functions of the International Legal Water Regime in the Mekong River Basin}

The Mekong River Commission — governed by the 1995 Mekong Agreement, the only specific legally binding document on this issue - represents the only specific international organization for the sustainable development and management of the Mekong River. Therefore, when we discuss the function of the international legal water regime in the Mekong River basin, we should primarily pay attention to the MRC. However, a number of critiques raised against the MRC can be found in the relevant literature; for example, some allege that the 1995 Mekong Agreement is only a framework, and that its real effect on the Mekong River basin is actually very limited. They point out that, controlled by the donors, the MRC can hardly make any substantial decisions. Nevertheless, the fact is that the MRC has formulated a series of Programmes that can be treated as an important source of "soft law" for the sustainable development and management of the Mekong River water resources. These Programmes are related to several aspects of protecting the Mekong River Basin, which include integration, function for people, agriculture, flood and drought, climate change, navigation, environmental health, hydropower, water quality, and fishery. To some extent, these approaches can foster water resources management and 
improve water-related sectors. In the following chapter, we will concentrate on various aspects of different approaches to the MRC.

\subsubsection{Integration}

\subsubsection{Introduction}

How to most effectively eliminate poverty in the Mekong River Basin has always been an important issue many people care about. Even though the economy of the Mekong region has seen notable improvements in recent years, but there are still millions of people in that region who are struggling with poverty. ${ }^{319} \mathrm{~A}$ sustainable basin plan is therefore crucial to link economic development goals with poverty eradication. Taking this complex background into account, an integrated approach to basin planning has emerged for securing the equitable and reasonable utilization of the water resources in the Mekong River. This approach is commonly referred to as Integrated Water Resources Management (IWRM) and has the aim of strengthening the effectiveness and efficiency of the water and related resources management at both the trans-boundary and cross-sector levels. ${ }^{320}$

The IWRM approach is not only capable of managing the water and other related resources in a sustainable way, it is also a way to achieve a trade-off between the economic and social benefits as well as the sustainable development of the environment. ${ }^{321}$ There are three objectives defined for the IWRM approach: efficiency, equity and sustainability. Efficiency means promoting economic growth, not only by merely relying on the water resources base, but also by investing in the water service. The second objective is equity, which means allocating water and related resources by fully considering different circumstances of different economic and social groups. Last but not the least, as the third objective, sustainability focuses on conservation of the ecosystem and emphasizes that water resources and related resources are finite.

In 2010, the MRC formulated a Mekong IWRM Project based on the Water Utilization Programme (WUP). In 2011, the Lower Mekong Basin countries adopted

\footnotetext{
${ }^{319}$ Jacobs (n 93) 354.

${ }^{320}$ MRC, 'Basin Planning' (Official Website of the MRC) < http://www.mrcmekong.org/topics/basinplanning/> accessed 02 October 2016.

${ }^{321}$ Olli Varis, Muhammad M. Rahaman and Virpi Stucki, 'The Rocky Road from Integrated Plans to Implementation: Lessons Learned from the Mekong and Senegal River Basins' (2008) 24/1 Water Resources Development 103, 103.
} 
the IWRM-based Basin Development Strategy that sets forth "how Mekong Countries will share, utilize, manage and conserve the Mekong water and related resources to achieve the goals of the 1995 Mekong Agreement." ${ }^{322}$ This comprehensive planning Programme addresses the opportunities, challenges and risks in Mekong's water sector as well as in other related sectors. All the Lower Mekong Basin countries should commit to trying their best to manage the river basin's water resources and to building a stable future. ${ }^{323}$

\subsection{Mekong IWRM (Integrated Water Resources Management) Project}

According to the analysis above, the role of the IWRM can be seen as a cornerstone for managing the water resources and water-related resources in the Mekong River Basin. Therefore, in September of 2010, the MRC formulated the Mekong IWRM Project based on the Water Utilization Programme (WUP). ${ }^{324}$ This project follows the IWRM's principles and can proactively involve all other Programmes and all relevant national authorities. In order to put the principles of the IWRM into practice, MRC has taken a series of measures: For example, the "MRC Procedures and Technical Guidelines" was developed as a tool for implementation of the IWRM. Furthermore, MRC worked out the "Strategic Directions for 2011 to 2015" for its implementation at the national and the sectorial level. ${ }^{325}$

This project works through a three-tiered approach, which combines the regional, transboundary and national levels. The main mission of this approach is to facilitate reciprocal cooperation, communication and knowledge exchange among all three levels for a more effective and efficient IWRM. ${ }^{326}$ At the regional level, based on the advices and facilitations from the MRC, the projects addressed basin-wide issues within the region. At the trans-boundary level, bilateral and multilateral cooperation

\footnotetext{
${ }^{322}$ MRC, 'Mekong Integrated Water Resources Management Project' (Official Website of the MRC) $<$ http://mrcmekong.mrcdev.info/about-mrc/programmes/mekong-integrated-water-resourcesmanagement-project/> accessed 02 October 2016.

323 Ibid.

${ }^{324}$ MRC Secretariat, 'Mekong IWRM Project Inception Report' (2010) Mekong Integrated Water Resources Management Project, Executive Summary < http://mrcmekong.mrcdev.info/assets/Publications/Programme-Documents/2010-09-29-FinalInception-ReportMIWRMP.pdf> accessed 29 September 2016.

325 Ibid.

${ }^{326}$ Ibid.
} 
becomes crucial for implementing projects. The cooperation meant here is not only that between two or more member countries, but also between cross-country projects that are facilitated through the MRC Secretariat. At the national level, this project focuses on the gaps in the project's implementation caused by the national water resource management. ${ }^{327}$

According to the approach above, the key characteristic of the IWRM could also be presented as "all activities are inter-linked" ${ }^{328}$. All approaches contribute to each other, and all Member Countries play an important role in the implementation of the IWRM. Through this approach, issues such as "national level capacity building, establishment of environmental baseline, and the involvement of the upstream MRC dialogue partners" ${ }^{329}$, which have arisen during the implementation of the IWRM, can be addressed equally and reasonably. ${ }^{330}$

\subsection{IWRM-based Basin Development Strategy}

In 2011, the Lower Mekong Basin countries adopted the IWRM-based Basin Development Strategy. This strategy progresses beyond national and sector planning ${ }^{331}$ and focuses on comprehensive basin planning that can combine the opportunities, challenges and risks of the Mekong's future development in the water sector and other relevant sectors. This strategy is also part of the MRC's commitment as a response to the Article 2 of the 1995 Mekong Agreement, which calls for a basin development plan. Therefore, the implementation of this strategy requires commitment from all Member Countries. ${ }^{332}$ The scope of this strategy covers regional and national planning for sustainable development and management. It tries to maintain a balance between economic, environmental and social outcomes, and also to assess the mutual benefits of Member Countries. The strategy defines the scope of the opportunities and the relevant risks of the water resources development (hydropower, irrigation, water supply, flood and drought management) and other

\footnotetext{
327 Ibid.

${ }^{328}$ Ibid.

${ }^{329}$ MRC (n 324).

${ }^{330}$ Ibid.

${ }^{331}$ IWRM-based Basin Development Strategy [2011] Mekong River Commission, 1.1 Purpose and Scope of the Strategy <http://mrcmekong.mrcdev.info/assets/Publications/strategies-workprog/BDP-

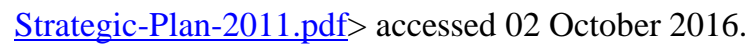

${ }^{332}$ Ibid.
} 
water-relevant development (fisheries, navigation, environment and ecosystems, watershed management) and also mentions the related measures for seizing opportunities and minimizing risks. It also enables a "coordinated, transparent and participatory" 333 process.

The objectives of this strategy should at first align with the objectives of the 1995 Mekong Agreement, which are "Protection of the environment and ecological balance; Sovereign equality and territorial integrity; Reasonable and equitable utilization; Maintenance of flows on the mainstream; Prevention and cessation of harmful effects; State responsibility for damages; Freedom of navigation; and Response to emergency situations". ${ }^{334}$ According to the MRC Summit Declaration in 2010, this strategy should also consider the importance of "managing the risks of floods and droughts; integrating sustainability considerations into the development of the Basin's hydropower potential; minimizing deterioration of water quality, loss of wetlands and deforestation, which present risks to biodiversity and people's livelihoods; managing the Basin's unique natural fisheries; and researching and addressing the threat to livelihoods posed by climate change". ${ }^{335}$ Based on the 2005 "IWRM Strategic Directions", there are eight key areas for the sustainable and equitable development of the Mekong River Basin, which are "Economic development \& poverty alleviation; Environmental protection; Social development and equity; Dealing with climate variability; Information based planning and management; Regional cooperation; Governance; Integration through basin planning" ${ }^{336}$.

The approaches of this strategy focus on the connection of national and sub-national plans with basin-level opportunities through trans-boundary cooperation. To consider the water and related resources at the national and sub-national level and then build the interconnection between national and basin planning, an integrated evaluation has been conducted as a basis for discussion and negotiation on the water and related resources development and associated trans-boundary impacts. ${ }^{337}$ Furthermore, the

\footnotetext{
333 Ibid.

${ }^{334}$ IWRM-based Basin Development Strategy (n 331) 1.2 Objectives and Vision Underpinning the Strategy.

335 Ibid.

${ }^{336}$ Ibid.

${ }^{337}$ IWRM-based Basin Development Strategy (n 331) 1.3 The Approach to Strategy Development.
} 
strategy itself also needs to be updated regularly according to some variable elements. ${ }^{338}$

\subsubsection{Summary}

By considering the complexity of the relationship between the sustainable development of environment and poverty eradication, we can draw the conclusion that the IWRM can make a significant contribution to the water and related resources management and development in the Mekong River Basin. As the core institution for water resources management and development in the Mekong River Basin, the MRC plays a crucial role and formulates related project and additional strategy, which aims to combine the water and other related resources development and also to maintain a balance between economic development and environmental sustainability. The MRC's project and strategy approaches concentrate on the interconnection of the national level and the basin level, and also the link between sectors. However, these two tools for the integration in Mekong River basin are not effective enough. Both are only documents formulated by the MRC. In reality, their implementation is ineffective. ${ }^{339}$ Still, this is a positive phenomenon with regards to the implementation of the 1995 Mekong Agreement, and can at least support the development of the Basin to achieve the balance among economical, social and environmental interests. ${ }^{340}$

\subsubsection{Functions for the People}

\subsubsection{Introduction}

There is no doubt that the Mekong River matters a great deal in the everyday lives of tens of millions of people. It impacts many aspects of their existence, including access to trade, food security and people's livelihoods. On the one hand, the natural resources of the Mekong River have massive potential for pushing regional economic growth and improving people's lives. On the other hand, agricultural irrigation, hydropower projects and cross-border waterway trade will also exert certain negative impacts on the Mekong's people. Based on this background, the MRC provides basinwide strategic planning and technical advice to state agencies. It works together with

\footnotetext{
${ }^{338}$ Ibid.

${ }^{339}$ Boer, Hirsch, Johns, Saul and Scurrah (n 11) 91.

${ }^{340}$ Ibid.
} 
political leaders and policy makers and supports implementation of the policies. ${ }^{341}$ This not only helps the Member Countries ensure sustainability by utilizing the natural resources of the Mekong River Basin, but also fosters poverty eradication in a way that involves the basin and the people as a whole. ${ }^{342}$

There are two typical Programmes in the MRC that reflect this consideration of people. One is the Environmental Programme, which connects the people and the basin environment together. The other is the Basin Development Plan Programme, which sets poverty eradication as its primary goal. To improve actions of these two Programmes, the MRC also conducted research on utilization of the aquatic ecosystems. This research demystified how people will benefit from the aquatic ecosystem and how people are affected by the changes to the aquatic ecosystem. ${ }^{343}$

\subsection{Environmental Programme}

As mentioned, the Mekong River is an important basis for the local people's livelihood. Even though the environment of the Mekong River Basin is currently in good condition, there are still challenges to be overcome, such as high nutrient concentrations in the Mekong Delta, decrease of the soil quality, the risk caused by industrialization and the climate change and so forth. ${ }^{344}$ Due to these problems, Articles 3 and 7 of the 1995 Mekong Agreement set out provisions for protecting the environment from harm by devising a development plan and utilizing water resources, as well as for mitigating the negative impacts of water resources development and utilization ${ }^{345}$ Following the Agreement, the MRC therefore set up an Environmental

\footnotetext{
${ }^{341}$ MRC, 'People' (Official Website of the MRC) < http://mrcmekong.mrcdev.info/topics/people/> accessed 02 October 2016.

342 Ibid.

${ }^{343}$ MRC, 'People' (Official Website of the MRC) < http://mrcmekong.mrcdev.info/topics/people/> accessed 02 October 2016.

${ }^{344}$ MRC, 'Environment Programme’ (Official Website of the MRC)

<http://mrcmekong.mrcdev.info/about-mrc/programmes/environment-programme/> accessed 02

October 2016.

${ }^{345}$ Environmental Programme 2011-2015 [2010] Mekong River Commission, Executive Summary <http://mrcmekong.mrcdev.info/assets/Publications/Programme-Documents/Environment-Programme2011-2015-1-November.pdf> accessed 02 October 2016.
} 
Programme in 1996 to support cooperation between the Member Countries and maintain the balance between economic development and ecological conservation. ${ }^{346}$ This Programme provides environmental and social knowledge to support the basin's management and development, for example in the process of implementing the regional Procedures for Water Quality. It also provides action plans for Member Countries to respond to environmental emergencies. In addition to this, there are also some sections that link the people in the Mekong region with the surrounding environment. They call for communication of the water quality results and river water 'Report Cards' to national line agencies, and try to support people's understanding of the relationship between their daily lives and the environment they live in. In order to improve people's environmental awareness, the Environmental Programme offers different materials such as training kits that contain maps and graphic information of the Mekong River and its people in local languages. ${ }^{347}$ Moreover, surveys or monitoring activities of this Programme lead to greater understanding among communities about the relationship between their activities and the river's quality. ${ }^{348}$

\subsection{BDP Programme}

In order to achieve the goals laid out in the 1995 Mekong Agreement, namely that the Member countries should "promote, support, cooperate and coordinate in the development of the full potential of sustainable benefits to all riparian states", the Basin Development Planning Programme was established by the MRC as a formal mechanism in $2001 .^{349}$ By setting poverty alleviation as a primary goal, the BDP Programme combines poverty reduction with sustainable economic development. ${ }^{350}$ The MRC's function for the people is reflected in the fact that people's livelihoods have always been at the core of the Basin Development Plan.

\footnotetext{
${ }^{346}$ Ibid.

${ }^{347}$ MRC, 'Environment Programme' (Official Website of the MRC)

<http://mrcmekong.mrcdev.info/about-mrc/programmes/environment-programme/> accessed 02 October 2016

348 Ibid.

${ }^{349}$ Programme Document Basin Development Plan Programme 2011-2015 [2011] Mekong River Commission, Executive Summary <http://mrcmekong.mrcdev.info/assets/Publications/ProgrammeDocuments/BDP2011-2015-Programme-Doc-June2011.pdf> accessed 02 October 2016.

${ }^{350}$ MRC, 'Basin Planning' (Official Website of the MRC) < http://www.mrcmekong.org/topics/basinplanning/> accessed 02 October 2016.
} 


\subsubsection{Summary}

As laid out above, the MRC's function for the Mekong's people is mainly reflected in its attempts to promote regional economic growth and eradicate (or at least alleviate) poverty and also to improve the public environmental awareness by virtue of the socalled Environmental Programme and the BDP Programme. Except for actions of these two Programmes, there are no other specific projects or detailed and clear approaches to strengthening its function for the people. Based on actions of these two Programmes, the MRC chiefly aims to alleviate the poverty problem, and takes a number of measures for turning policies into practice and promotes people's environmental awareness of the relationship between their activities and the river's condition. However, although these two Programmes can provide a certain amount of guidance for some basin development activities, we cannot oversee the fact that the legal status of the actions of these two Programmes is very soft and vague. In conclusion the MRC's function for people focuses on poverty reduction, for this is the most direct means of improving people's livelihoods. However, this ignores other essential aspects pertaining to the Mekong's people, such as settlement, leisure life and so forth.

\subsubsection{Agriculture}

\subsubsection{Introduction}

In the Mekong River basin, more than 20 percent of the population live under the poverty line, and roughly 60 percent of the population rely on the local agriculture for their livelihood. ${ }^{351}$ The Mekong Countries are therefore going to a great deal of effort to develop the agricultural sector, and treat agriculture as a key point for reducing poverty. ${ }^{352}$

With a continuing expanding agricultural area and due to the regional climate, agriculture in the Mekong region relies heavily on irrigation. ${ }^{353}$ During the dry season, reasonable and sustainable irrigation is the most important basis for agricultural

\footnotetext{
${ }^{351}$ Katsuhiko Yamauchi, 'Climate change impacts on agriculture and irrigation in the Lower Mekong Basin' (2014) 12 Paddy and Water Environment 227, 228.

352 Ibid.

${ }^{353}$ Chu Thai Huanh and Thierry Facon, 'Irrigation in the Lower Mekong Basin Countires: The Beginning of a New Era?' Franois Molle, Tira Foran and Mira Kakonen (eds) Contested Waterscapes in the Mekong Region: "Hydropower, Livelihoods and Governance" (UK, 1st, Earthscan, 2009) 143.
} 
productivity, especially rice productivity in the Mekong Delta. ${ }^{354}$ On the one hand, the agricultural productivity affects the food supply in the Mekong River basin. ${ }^{355}$ On the other hand, paddy fields can also serve other functions, such as flood mitigation, soil quality conservation, and fishery improvement. ${ }^{356}$ In addition, agriculture in the Mekong Region also plays an important role for local economic growth based on the commercialization of the agricultural products. ${ }^{357}$ Normally, national agencies should take the responsibility for agriculture management and support. However, the implementation of agricultural management plans or water use plans in the Mekong region have certain trans-boundary and basin-scale impacts that cannot be comprehensively considered by the respective national agencies. ${ }^{358}$ Therefore, the MRC plays a key role in filling this gap. It makes efforts to gain an overview of member countries' agricultural development activities and to evaluate their combined effects or potential effects. ${ }^{359}$ This complementary role of the MRC is based on the integration of water-related sectors, such as agriculture, aquatic ecosystems, fisheries, hydropower development, navigation and so forth. ${ }^{360}$

There are already many national, international and bilateral agencies that are related to agricultural development and management of the Lower Mekong Basin. The MRC is now in the process of re-orienting its agricultural sector activities, and "focuses on providing advice, guidance and analysis for the sustainable development and

${ }^{354}$ Toshihiro Sakamoto, Nhan Van Nguyen, Hiroyuki Ohno, Naoki Ishitsuka and Masayuki Yokozawa, 'Spatio-temporal Distribution of Rice Phenology and Cropping Systems in the Mekong Delta with Special Reference to the Seasonal Water Flow of the Mekong and Bassac Rivers' (2006) 100 Remote Sensing of Environment 1, 2.

${ }^{355}$ Mohammed Mainuddin and Mac Kirby, 'Agricultural productivity in the lower Mekong Basin: trends and future prospects for food security’ (2009) 1 Food Security 71, 72.

${ }^{356}$ Takao Masumoto, Pham Thanh Hai and Katsuyuki Shimizu, 'Impact of paddy irrigation levels on floods and water use in the Mekong River basin’ (2008) 22 Hydrological Processes 1321, 1326.

${ }^{357}$ MRC, 'Agriculture \& Irrigation' (Official Website of the MRC) <http://www.mrcmekong.org/topics/agriculture-and-irrigation/> accessed 02 October 2016.

${ }^{358}$ Ingjerd Haddeland, Dennis P. Lettenmaier and Thomas Skaugen "Effects of irrigation on the water and energy balances of the Colorado and Mekong river basins” (2006) 324 Journal of Hydrology 210, 211.

${ }^{359}$ MRC, 'Redefining MRC's Role in the Agriculture Sector' (Official Website of the MRC) <http://www.mrcmekong.org/about-mrc/programmes/agriculture-and-irrigation-programme/redefiningmrc-s-role-in-the-agriculture-sector/> accessed 02 October 2016. ${ }^{360}$ Ibid. 
management of the Lower Mekong Basin". ${ }^{361}$ For the purpose of achieving this objective, it has established an Agriculture and Irrigation Programme. The following section will go into further detail about a series of activities carried out under this Programme that support the development of the agriculture of the Mekong River Basin.

\subsection{MRC's Agriculture and Irrigation Programme}

As mentioned, agriculture is very important for people in the Mekong Region to raise their living standard, improve their livelihood and eliminate poverty; therefore, this Programme aims to manage the sustainable development of the water resources in the agricultural sector. ${ }^{362}$ Most of its activities to this end concentrate on water management by monitoring agricultural use basin-wide. First of all, the main idea of these activities is to improve regional planning and combine national and regional perspectives about agricultural development. ${ }^{363}$ The second focus is improving and using regional outcomes to build individual countries' analytical and planning capacity for integrated approaches to land and water management. ${ }^{364}$ And thirdly, this Programme is meant to build MRC Secretariat's agricultural capacity. ${ }^{365}$

As the focus of this Programme's activities is on water management, it monitors agricultural water use to understand the basin-wide flow regime. Although many irrigation projects already to be found at the national level are very small, these projects have considerable cumulative impacts on entire agricultural communities. ${ }^{366}$ By implementing the aim of this Programme, real time flood and drought monitoring

\footnotetext{
${ }^{361}$ MRC, 'Redefining MRC's Role in the Agriculture Sector' (Official Website of the MRC) <http://www.mrcmekong.org/about-mrc/programmes/agriculture-and-irrigation-programme/redefiningmrc-s-role-in-the-agriculture-sector/> accessed 02 October 2016.

${ }^{362} \mathrm{MRC}$, 'Agriculture and Irrigation Programme' (Official website fo the MRC) <http://www.mrcmekong.org/about-mrc/completion-of-strategic-cycle-2011-2015/agriculture-andirrigation-programme/> accessed 02 October 2016.

${ }^{363}$ Agricultural and Irrigation Programme [2011] Mekong River Commission, Executive Summary < http://www.mrcmekong.org/assets/Publications/Programme-Documents/AIP-Pogramme-Doc-V4Final-Nov11.pdf $>$ accessed 02 October 2016.

${ }^{364}$ Ibid.

${ }^{365}$ Ibid.

${ }^{366}$ MRC, 'Agriculture and Irrigation Programme' (Official website fo the MRC) $<$ http://www.mrcmekong.org/about-mrc/completion-of-strategic-cycle-2011-2015/agriculture-andirrigation-programme/> accessed 02 October 2016.
} 
conditions can be relayed to national agencies for the sake of more quickly reacting to natural events, which will directly influence farmers' livelihoods. ${ }^{367}$ In addition, this Programme also includes topics about forestry and watershed management, which are also covered under the BDP Programme. ${ }^{368}$

\subsection{Demonstration of Multi-functionality of Paddy Fields Project}

Besides the function of food production, paddy fields have various functions, including "flood mitigation, groundwater recharge, stabilizing river flow, re-use of irrigation water, soil erosion control, landslide prevention, water purification, microclimate mitigation, protection of biodiversity, nurturing of aquatic ecosystems and aquaculture, organic waste processing and multiple domestic uses"369. The Paddy Fields Project was implemented within the framework of the Agriculture and Irrigation Programme introduced above. The reason for establishing this initiative can be primarily attributed to the need to analyse different functions of paddy fields and their contributions to the basin as a whole. ${ }^{370}$

There are two stages in this project. The first stage focuses on data collection at the basin-wide level, and also at the level of an experimental field plot. ${ }^{371}$ At this stage, several outputs have been created, such as land use maps, comparison maps of planted areas and precipitation, maps of monthly irrigation water use schemes, irrigation water use assessments as well as irrigation scheme databases, which are regularly reviewed and updated. The second stage of this project is to use a quantified assessment process to demonstrate specific functions, and a number of national teams are involved in this process. ${ }^{372}$ For example, one Thai team is focusing on three functions: flood mitigation, aqua-ecosystem and agro-ecosystem biodiversity, and buffering environmental risks. Another team from Vietnam is focusing on four

\footnotetext{
${ }^{367}$ Ibid.

368 Ibid.

${ }^{369}$ MRC, 'Demonstration of Multi-functionality of Paddy Fields' (Official Website of the MRC) <http://www.mrcmekong.org/about-mrc/programmes/agriculture-and-irrigationprogramme/demonstration-of-multi-functionality-of-paddy-fields/> accessed 02 October 2016.

${ }^{370}$ Ibid.

${ }^{371}$ Ibid.

${ }^{372}$ Ibid.
} 
functions: flood mitigation, nurturing aqua-ecosystems, soil conservation, and socioeconomic functions. ${ }^{373}$

3.1.3.1.3. Improvement of Irrigation Efficiency on the Paddy Field in the Lower Mekong Basin Project

The irrigation water used for rice production represents the greatest agricultural use of freshwater in the Mekong River Basin. ${ }^{374}$ Therefore, the efficiency of water use for paddy field irrigation is crucial to agricultural development and other related sectors. This project aims to improve irrigation efficiency by providing guidance to water managers. $^{375}$

In order to achieve this goal, there are three main objectives for this project: The first objective is to evaluate irrigation efficiencies and systems based on modern approaches in selected irrigation schemes. The second objective is to improve the capacity of each stakeholder to use modern concepts, modern tools and assessment procedures. The third objective is to produce guidelines for enhancing the efficiency of irrigation in paddy fields according to the actual conditions in Member Countries. ${ }^{376}$

Based on observations on selected schemes and assessment of the schemes' performance, the project analyzes the irrigation efficiencies in technical, managerial and institutional aspects. This analysis can be regarded as a vital basis for producing guidelines for efficient use of irrigation water. A modern approach that takes the interaction of surface and ground water into consideration was also applied for the analysis. ${ }^{377}$ MRC has already completed this project and wants to start a new Sustainable and Efficient Water Use Project. ${ }^{378}$

\footnotetext{
${ }^{373}$ Ibid.

${ }^{374}$ Huanh and Facon (n 353) 143.

${ }^{375}$ MRC, 'Improvement of Irrigation Efficiency' (Official Website of the MRC) $<$ http://www.mrcmekong.org/about-mrc/programmes/agriculture-and-irrigationprogramme/improvement-of-irrigation-efficiency/> accessed 02 October 2016.

376 Ibid.

${ }^{377}$ Ibid.

${ }^{378}$ MRC, 'Agriculture and Irrigation Programme' (Official website fo the MRC) $<$ http://www.mrcmekong.org/about-mrc/completion-of-strategic-cycle-2011-2015/agriculture-andirrigation-programme/> accessed 02 October 2016.
} 


\subsubsection{Summary}

Due to crucial role of agriculture for the Mekong Region, MRC formulated an Agricultural and Irrigation Programme to improve sustainable agricultural development in the Mekong River Basin. This Programme makes it possible for both regional and national measures for promoting agricultural development to be connected in a suitable way. There are also two related projects: One is for development of paddy fields' various functions, and therefore relevant to biodiversity conservation, groundwater recharging, forestry, river flow stabilization and so forth. The other is for improving irrigation efficiency by providing guidance to water managers. By evaluating the outcomes of these projects, it is obvious that they have significantly contributed to the sustainable development of the agriculture and irrigation in the Mekong region, and accordingly also to the economic growth in the Mekong River Basin.

\subsubsection{Flood and Drought}

\subsubsection{Introduction}

Floods have a huge impact on agriculture in the Mekong Region, primarily because of the damage they tend to cause. For example, floods can cause people to lose their home and even their lives, destroy property and infrastructure as well as hinder the cultivation of crops. However, many people neglect the fact that floods can also bring social, environmental and economic benefits: In the Mekong Region, for instance, floods can drive the basin's fisheries. ${ }^{379}$ Floodwater can be stored for irrigation purposes and alleviate the seawater intrusion during the dry season. ${ }^{380381}$ Furthermore, annual floods can also recharge the groundwater and alleviate water pollution. ${ }^{382}$ Although the cost of damage caused by floods amounts to about 60 to 70 million dollars each year, the benefits derived from these floods can be estimated to be worth

\footnotetext{
${ }^{379}$ Jacobs (n 93) 359.

${ }^{380}$ Ibid.

${ }^{381}$ Le Thi Viet Hoa, Nguyen Huu Nhan, Eric Wolanski, Tran Thanh Cong and Haruyama Shigeko, 'The Combined Impact on the Flooding in Vietnam's Mekong River Delta of Local Man-made Structures, Sea level rise, and Dams Upstream in the River Catchment' (2007) 71 Estuarine, Coastal and Shelf Science 110, 116.

${ }^{382}$ MRC, 'Flood \& Drought' (Official Website of the MRC)

<http://www.mrcmekong.org/topics/flood-and-drought/> accessed 02 October 2016.
} 
approximately 8 to 10 billion dollars. Therefore, it is important to improve flood management in the Mekong region so that we can make use of the benefits floods bring about while mitigating the costs incurred from damage. ${ }^{383}$

There are various methods to minimize the risks of floods, such as improvement of land-use, establishment of regional flood emergency plan, better preparedness, and development of flood control etc. The MRC plays an important role with regards to basin-wide coordination of flood mitigation and maintenance of benefits for Member Countries. The MRC also takes the responsibility collecting data from hydrometeorological stations, and predicts the water levels from 22 forecast points on the mainstream. These forecasts are sent to National Mekong Committees and other related agencies or organizations. ${ }^{384}$

Compared with the cost of floods, the cost of droughts is much greater, given that droughts produce little or no benefit, yet have consequences that are even more severe. Droughts cause water shortages, reduction of income, and also disease. They can also negatively affect agriculture, fisheries and livestock raising. Therefore, the MRC and its Member Countries are making efforts to design strategies aimed at improving people's lives in consideration of the negative impacts of droughts. ${ }^{385}$

The MRC's important role can also be reflected by its river-monitoring service, the creation of the Flood Management and Mitigation (FMM) Strategy, and the establishment of the FMM Programme. The establishment of a Drought Management start-up project by the MRC was one part of the Information and Knowledge Programme in 2010. ${ }^{386}$ "It also provides facilitation on water and related issues, capacity building, and technology transfer for flooding issues of regional and transboundary relevance." 387

\subsection{River Monitor Service}

The MRC provides river monitor services to Member Countries, including flood forecasting. Firstly, the MRC monitors the river level all year round and provides related observations and forecasts. This information is sent to the national

\footnotetext{
383 Ibid.

${ }^{384}$ Ibid.

385 Ibid.

386 Ibid.

${ }^{387}$ Ibid.
} 
governments, and can contribute to the existing national disaster forecast and warning systems. ${ }^{388}$

There are three parts in this river monitor service: daily observation and forecast, daily observation compared to long-term averages, and the real time observation. In the first part, daily observation and forecast, MRC collects data of water levels from 22 hydrological stations. During the flood season, the data is updated daily, and during the dry season, weekly. In the dry season, it is very important to observe low water levels and compare the information to the long-term average. Moreover, the hydrological stations also provide real time information, which is updated every two hours and summarized for 24-hour and 30-day time periods. ${ }^{389}$

\subsection{Flood Management and Mitigation Programme (FMMP)}

The MRC's FMMP aims to mitigate the negative impacts of floods while maintaining the flood-related benefits. Equipped with flood forecasting data and tools to mitigate negative impacts, the Regional FMM Center in Phnom Penh has helped national agencies manage a number of floods. ${ }^{390}$

This Programme provides forecasting and early warnings during the flood season. Data is collected from 138 hydro-meteorological stations, and used to forecast the water levels at 23 points on the Mekong River system. Every day, the data is updated and sent to National Mekong Committees, NGOs, the media, and also the public by email, fax, and websites. Moreover, this Programme provides daily warnings of rising water levels to governmental agencies and communities in Cambodia and Lao PDR. Flood markers and community billboards with information about current and predicted water levels have also been provided by this Programme. FMMP makes efforts to reach wide audiences throughout the Mekong River basin in various ways, such as online broadcasting, radio communication, guidebooks dissemination, and workshops. By taking the Mekong's tributaries into consideration, the FMMP is also

\footnotetext{
${ }^{388}$ MRC, 'River Monitoring' (Official Website of the MRC) <http://www.mrcmekong.org/mrc/rivermonitoring/> accessed 02 October 2016.

${ }^{389}$ Ibid.

${ }^{390}$ MRC, 'Flood Management \& Mitigation Programme' (Official Website of the MRC) <http://www.mrcmekong.org/about-mrc/programmes/flood-management-and-mitigation-programme/> accessed 02 October 2016.
} 
developing a flash flood guidance system for mitigating the related risk for people and infrastructure. ${ }^{391}$

As one of the main platforms of FMMP to exchange information across expertise areas among regions, the regional Flood Forum supports dialogue and knowledge production, and coordinates "flood-management activities with planners, scientists, international organizations, and civil society organizations ${ }^{\$ 392}$. The proceedings from the Forum are also important contents in MRC Conference Proceedings and Workshops publications. ${ }^{393}$

Obviously, the flood management is very important, and it relies on regional cooperation. By organizing training workshops, study visits, and other related activities, FMMP makes a significant contribution to the improvement of crossregional cooperation and facilitates multi-layered information sharing. These measures help decision-makers to exchange their experiences and contribute to region-specific solution development. ${ }^{394}$

\subsection{Drought Management Project}

The Drought Management Start-up Project was established as one part of the Information and Knowledge Management Programme (IKMP). ${ }^{395}$ In accordance with the IKMP, information about water levels mitigation is updated on a daily basis and can be compared information from the previous year. This can help residents to plan local irrigation measures, fisheries and navigation. ${ }^{396}$ There have also been related supporting studies in response to increasing drought situations, such as vulnerability assessment, drought mapping and scenario development. The database on groundwater will also be set up for land use planning and implementation of the

\footnotetext{
${ }^{391}$ Ibid.

392 Ibid.

393 Ibid

394 Ibid.

${ }^{395}$ MRC, 'Flood \& Drought' (Official Website of the MRC)

<http://www.mrcmekong.org/topics/flood-and-drought/> accessed 02 October 2016.

${ }^{396}$ MRC, 'Information \& Knowledge Management Programme' (Official Website of the MRC) <http://www.mrcmekong.org/about-mrc/programmes/information-and-knowledge-managementprogramme/> accessed 02 October 2016.
} 
procedure on water use monitoring. ${ }^{397}$ The MRC Data and Information Services Portal was also set up as part of the IKMP Programme, of which the drought monitor is an important part. ${ }^{398}$

\subsubsection{Summary}

In conclusion, floods do not always play a negative role in the Mekong River Basin. They also bring advantages for regional agriculture, fisheries, water quality and other related aspects. Droughts, in contrast, offer no clear benefit to the region. Therefore, the MRC's function with respect to floods and droughts can be said to aim at mitigating the adverse impacts and fostering the beneficial impacts of floods; to this end, the MRC has formulated a specific Programme, the FFMP, to manage and mitigate floods. In order to manage droughts, the MRC relies on another Programme, called the Information and Knowledge Management Programme, to keep observing the information and data during the dry season, and to help riparian residents improve their agricultural irrigation plans, land use planning, and water use monitoring. This function has mainly been implemented through data and information collection, as well as a monitoring and forecasting system.

\subsubsection{Climate Change}

\subsubsection{Introduction}

Climate change has brought unavoidable changes in weather patterns to the Mekong River Basin, thereby drawing public interest number of related studies expound the vulnerability of the Mekong River Basin under the impacts of climate change, such as rising temperature and increasing precipitation. ${ }^{399}$ These phenomena cause a series of weather events such as typhoons, frequent floods and droughts that can seriously affect people's livelihoods and decrease the productivity of agriculture and

\footnotetext{
${ }^{397}$ Information and Knowledge Management Programme [2010] Mekong River Commission, 1.3 Considered Issues for IKMP 2011-2015 <http://www.mrcmekong.org/assets/Publications/ProgrammeDocuments/ProDoc-2011-2015final-versionIKMP.pdf> accessed 02 October 2016.

${ }^{398}$ MRC, 'MRC Data and Information Services Portal' (Official Website of the MRC) <http://portal.mrcmekong.org/index> accessed 02 October 2016.

${ }^{399}$ Yamauchi (n 351) 227.
} 
fisheries. ${ }^{400}$ Saltwater intrusion in the Mekong Delta is also an important aspect of climate change requiring consideration. ${ }^{401}$ Rising sea levels do not merely cause saltwater intrusion, which in turn destroys agriculture, fisheries, and aquaculture; it also submerges part of the land and causes people to be displaced. ${ }^{402}$

In order to rise to the challenge of the current urgent situation, the MRC is making efforts to adapt to climate change, as well as conducting research to get a better understanding of how people can adapt to climate change. Some regional and national projects that include adaptation initiatives are now underway. The related adaptation strategies focus chiefly on water resource management, natural disaster management and agricultural development. ${ }^{403}$ Nowadays, decision-makers and strategists are already aware of the increasing impacts of climate change and take climate change into consideration when designing integration policies and basin development plans. As an important support for its member countries, the MRC supplies technical advice and dialogue-based forums aimed at strengthening knowledge sharing and improving the understanding of climate change within the trans-boundary context. ${ }^{404}$

\subsection{Climate Change and Adaptation Initiative}

Due to the potential risks that climate change could bring about, the MRC is making efforts to pinpoint the critical impacts of climate change, and also to determine how it can help its Member Countries better adapt to climate change and overcome the catastrophes trigged by climate change. With this in mind, it formulated the Climate Change and Adaptation Initiative (CCAI), which is a cooperative effort among Member Countries to share and prove the worth of adaptation strategies. ${ }^{405}$ The goal of the CCAI is to encourage "an environmentally sound, economically prosperous and socially just Mekong River Basin, responsive and adapting to the challenges induced

\footnotetext{
${ }^{400}$ D. G. Kingston, J. R. Thompson and G. Kite, 'Uncertainty in Climate Change Projections of Discharge for the Mekong River Basin’ (2011) 15 Hydrology and Earth System Sciences 1459, 145960.

${ }^{401}$ MRC, 'Climate Change' (Official Website of the MRC) <http://www.mrcmekong.org/topics/climate-change/> accessed 02 October 2016.

402 Ibid.

${ }^{403}$ Ibid.

${ }^{404}$ Ibid.

${ }^{405}$ Boisson de Chazournes (n 45) 113.
} 
by climate change." ${ }^{\prime 406}$ With the focus on a basin-wide approach, the initiative intends to implement effective strategies for climate change adaptation through coordination. ${ }^{407}$ The adaptation should therefore also plan at "various levels and be applied at priority locations throughout the basin". ${ }^{408}$

The MRC and its partners use a special and effective initiative for climate change adaptation planning, which is to share "how people adapt to climate change through local strategies". A part of the task of the CCAI is to develop an adaptation planning process by setting up a pilot project at demonstration sites in Member countries. ${ }^{409}$ Therefore, the planning is formulated based on local knowledge and local adaptation strategies to identify which practices can be utilized as a basin-wide tool. Demonstration, knowledge sharing, and learning to continuously foster methods and results are three vital conditions for the adaptation planning's establishment. Adaptation planning processes will be implemented at the local level, for relevant sectors, and at the basin-wide and trans-boundary levels. ${ }^{410}$

The CCAI takes measures to build the capacities on climate change at the national level by carrying out awareness-raising activities. ${ }^{411}$ The CCAI cooperates with other relevant institutions, specialists, programs and communities to formulate and implement the local strategies for each of the Member Countries. This Initiative provides advice-, mentoring- and learning-exchange visits to the government staff from other countries and sites. The CCAI also produces training and advisory manuals for mass dissemination of proven measures and approaches. ${ }^{412}$ Thanks to the

${ }^{406}$ MRC, 'Climate Change' (Official Website of the MRC)

<http://www.mrcmekong.org/topics/climate-change/> accessed 02 October 2016.

${ }^{407}$ Philipp Magiera, 'Measures for the Adaptation to Climate Change in the Mekong Region' (2013)

Deutsche Gesellschaft für Internationale Zusammenarbeit (GIZ) GmbH, MRC-German Development Cooperation <https://www.deutsche-digitale-

bibliothek.de/binary/C34BIVVO2KCB5SJS3KCFRTV5554DAJI/full/1.pdf > accessed 02 October 2016.

${ }^{408}$ MRC, 'Climate Change and Adaptation Initiative' (Official Website of the MRC)

<http://www.mrcmekong.org/about-mrc/programmes/climate-change-and-adaptation-initiative/> accessed 02 October 2016.

${ }^{409}$ Ibid.

${ }^{410}$ Ibid.

${ }^{411}$ Ibid.

${ }^{412}$ Ibid. 
efforts of the CCAI, focal information about climate change is presented in the respective local language on posters and in cartoons and grassroots comics. These tools can also raise the awareness of climate change among local residents in the Mekong River Basin. ${ }^{413}$

The CCAI also promotes dialogues with stakeholders throughout the region. In July of 2008, the MRC launched "a process of dialogue and consultation on climate change with government agencies, academic institutions, non-government organizations and Development Partners" ${ }^{414}$. Within this process, there are also several events for dialogue and consultation on climate change among stakeholders, such as Environment and Climate Symposium. ${ }^{415}$

\subsubsection{Summary}

It is obvious that climate change can also be regarded as a threat for the sustainable development of the Mekong River Basin. The resulting negative consequences, such as extreme weather and disaster, can impose huge effects on the Mekong region in many regards. The agriculture, aquaculture and fisheries can be heavily influenced, and therefore people's livelihoods and the regional economy can also be affected. Because of this situation, the MRC is making a series of efforts to adapt to climate change, and most of these efforts focus on water resource management, disaster management and agriculture development. Established by the MRC, the Climate Change Adaptation Initiative, for instance, utilized unique ways to share different strategies for climate change adaptation across the region and to identify which strategy is most suitable to implement basin-wide. This Initiative also raised public awareness about climate change, helped local people to build capacity as well as promoted dialogues and cooperation between stakeholders among the member countries. We can therefore conclude that this Initiative promotes the cooperation of the Member Countries on the issue of climate change, and is vital for regional sustainable development and water resources management.

\footnotetext{
413 Ibid.

414 Ibid.

415 Ibid.
} 


\subsubsection{Navigation}

\subsubsection{Introduction}

The Mekong River has been a vital passage for the people and goods for hundreds of years. It still plays an important role in regional transportation, which is closely related to people's lives, international trade, and tourism development. The Mekong River and its major tributaries are generally navigable during the wet season based on the high water level. However, at the north of the border between Cambodia and Lao PDR, there is a 14-km impasse at the Khone Falls. ${ }^{416}$ The section at the north of the Khone Falls is very narrow and rapid, and its annual water level varies largely. This situation is a challenge to the navigability in this area. Because this section can be seen as an important connection between China and the lower Mekong Countries, the port infrastructure is a crucial issue ${ }^{417}$ Moreover, the section south of the Khone Falls has a very vital function for the river-based trade transportation, especially for Vietnam and Cambodia. This Section also connects the Mekong Region to the world, which can sail container ships directly to Europe and the US. ${ }^{418}$

Article 9 of the 1995 Mekong Agreement states: "Freedom of navigation shall be accorded throughout the mainstream of the Mekong River without regard to the territorial boundaries, for transportation and communication to promote regional cooperation." As one of the cross-regional organization and the institutional organizations of the Mekong Agreement, the MRC is meant to "manage, assist in developing, and monitor cross-border waterborne transport." ${ }^{419}$ The MRC formulates a Navigation Programme, which is a key tool for supporting the management, development, and improved utilization of the Mekong waterways. However, some sections of the Mekong waterway are located at political borders for some countries. To some extent, this makes navigation complex and is therefore an important issue for the work of this Programme. ${ }^{420}$ Safer and more environmentally friendly navigation is the central goal of the Mekong's Navigation. MRC and its Member countries all make

\footnotetext{
${ }^{416}$ MRC, 'River Transport' (Official Website of the MRC) <http://mrcmekong.mrcdev.info/topics/river-transport/> accessed 02 October 2016.

${ }^{417}$ Ibid.

${ }^{418}$ Ibid.

${ }^{419}$ Ibid.

${ }^{420}$ Ibid.
} 
efforts to achieve this goal: Firstly, according to the aim of safety, some initiatives of the Navigation Programme provide installations for safety assistance in less-navigable areas of the river. ${ }^{421}$ Secondly, in order to promote a friendlier navigation system, this Programme has also facilitated several agreements for improving the effectiveness of regional trade. ${ }^{422}$ Signed in 2009 between Cambodia and Vietnam, the Treaty on Waterway Transportation has the purpose of reducing cross-border navigation restrictions and improving efficiency and safety standards. Furthermore, this treaty also encourages several activities intended to preserve the Mekong River's environment by monitoring up-to-date circumstances, strengthening coordination, improving regulations, and controlling the navigation. These activities can reduce the frequency of shipping accidents and therefore mitigate the pollution by oil spill and other dangerous substances. ${ }^{423}$

\subsection{Navigation Programme}

The Mekong River is a vital passageway for people and goods of riparian countries. On the one hand, the Mekong River brings economic benefits based on its navigational function. On the other hand, the increase in traffic on the river also has adverse impacts, such as oil spills from shipping accidents, as well as posing safety risks to river users and so forth. Therefore, the MRC has formulated the Navigation Programme, which is designed to establish legal principles that can ensure effective and safe river-borne transportation for MRC Member Countries. ${ }^{424}$

There is a series of activities to be found in the Navigation Programme: for example, a number of surveys have been launched for fostering traffic on the Mekong River system, which covers a number of stretches along the Mekong River and some tributaries and distributaries, such as Tonle Sap, Vam Nao, and Bassac Rivers. ${ }^{425}$ These surveys provide support to efficient and safe transportation on the Mekong River. ${ }^{426}$ Moreover, this Programme has also developed the Electronic Navigation

\footnotetext{
${ }^{421}$ Ibid.

${ }^{422}$ Ibid.

${ }^{423}$ Ibid.

${ }^{424}$ MRC, 'Navigation Programme' (Official Website of the MRC) <http://www.mrcmekong.org/aboutmrc/programmes/navigation-programme/> accessed 02 October 2016.

${ }^{425}$ Ibid.

${ }^{426}$ Ibid.
} 
Charts (ENCs) of the Mekong River and some tributaries in Vietnam. These are used in on-board computer-based navigation information systems in modern vessels. ${ }^{427} \mathrm{In}$ spite of the surveys and ENCs, several studies have also been designed that consider issues concerning "waterway channels, buoys and beacons, standard specifications for ship locks for hydropower development and modern standards for passenger jetties" ${ }^{428}$. Another aim of the Navigation Programme is to improve cross-border trade and transport. This facilitated the formulation of the Agreement on Waterway Transport between Cambodia and Vietnam in 2009, which aims to improve freedom of navigation on the Mekong waterway between these two countries and also create greater access to foreign ships. A focal point of this agreement is binding Cambodia and Vietnam together to decrease the official restrictions on cross-border navigation. ${ }^{429}$ As a result, regional and international trade can be fostered, and related river based customs and immigration procedures can be made more efficient and simple. Based on this agreement, there are also other measures that can promote the vessels' utilization of 65 internal ports in Cambodia and Vietnam to be safer and more efficient. ${ }^{430}$ In the long run, this agreement can foster export potential and help Cambodia and Vietnam to achieve the goal of poverty alleviation. ${ }^{431}$ Furthermore, this agreement intends to improve standards of efficiency and safety. It contains rules and regulations that aim to improve the safety of the shipping of dangerous goods, which can promote the safety and reliability of waterway trade. ${ }^{432}$

Waterway safety is also an emphasis of the Navigation Programme. The Programme provides operational navigation aids consisting of professional buoys and beacons along dangerous stretches. These measures make the Mekong River safer and more

\footnotetext{
${ }^{427}$ Ibid.

${ }^{428}$ Ibid.

${ }^{429}$ MRC, 'Navigation Programme' (Official Website of the MRC) < http://www.mrcmekong.org/aboutmrc/programmes/navigation-programme/> accessed 02 October 2016.

${ }^{430}$ MRC, 'Cambodia and Viet Nam formally open-up cross-border river trade on the Mekong'

(Vientiane 17 December 2009) <http://mrcmekong.mrcdev.info/news-and-events/news/cambodia-andviet-nam-formally-open-up-cross-border-river-trade-on-the-mekong/> accessed 02 October 2016.

${ }^{431}$ Ibid.

${ }^{432}$ MRC, 'Navigation Programme' (Official Website of the MRC) <http://www.mrcmekong.org/aboutmrc/programmes/navigation-programme/> accessed 02 October 2016.
} 
navigable. ${ }^{433}$ Nowadays, the Mekong River can be navigated 24 hours a day. Although the Agreement has notably fostered the safety of channels in Cambodia and Vietnam, nighttime navigation between Lao PDR and Thailand still needs to be improved. ${ }^{434}$ Due to these situations, a Risk Analysis and an Environmental Impact Assessment are underway in Lao PDR and Thailand to ascertain the risks and impacts of increased navigation and port activities related to the storage, handling and transport of dangerous goods on the Mekong River. ${ }^{435}$ A Management Information System has been implemented under this Programme for Phnom Penh Autonomous Port (between Cambodia and Vietnam) and aims to better facilitate vessel transportation and planning. Additionally, two tidal monitoring stations have been set at the Mekong and Bassac estuaries, which provide water levels at the river entrances to incoming and outgoing ships. This Programme also developed an identification system to improve vessel tracking on the Mekong River between Phnom Penh and the CambodiaVietnam border. ${ }^{436}$ Another important aspect of this Programme is that cooperation between China and the MRC has been strengthened. China has committed to improving navigation safety and cooperating with the MRC and Myanmar to foster navigation on the Lancang-Mekong River. ${ }^{437}$

\subsubsection{Summary}

The 1995 Mekong Agreement made clear the importance of navigation for the Mekong River Basin. In accordance with navigation's important role, and as the only organization in the river basin, the MRC has formulated a Navigation Programme to improve this function. This Programme established a series of measures focusing on different aspects, such as safety, efficiency, navigability, pollution of shipping transportation, improvement of cross-border transport and trade, and so forth. Facilitated by this Programme, a bilateral, legally binding agreement between Cambodia and Vietnam called the Agreement on Waterway Transport has been signed as well. This agreement fosters cross-border transport and trade by decreasing official restrictions. It could also increase the potential of the exportation and

\footnotetext{
${ }^{433}$ Ibid.

${ }^{434}$ Ibid.

435 Ibid

${ }^{436}$ Ibid.

${ }^{437}$ Ibid
} 
economic growth, and, as a result, help Cambodia and Vietnam achieve their goal of poverty eradication. Moreover, this agreement also takes the environmental issue (as it relates to the transportation of hazardous goods) into account. Last but not least, the Navigation Programme is also improving the cooperation between China and the MRC. China has expressed its commitment to improving the navigation of the Lancang-Mekong River based on its cooperation with Myanmar and the MRC. Given the progress listed above, we can draw the conclusion that, thanks to efforts on the part of the MRC, the function of navigation has seen a series of improvements, making a notable contribution to regional development.

\subsubsection{Environmental Health}

\subsubsection{Introduction}

The Mekong River is the tenth largest river in the world and is home to a large amount of flora and fauna. ${ }^{438}$ However, the environment in the Mekong River Basin has been affected by various activities carried out by human beings, such as capture fisheries, intensive irrigation for agriculture and mainstream development proposals. ${ }^{439}$ Climate change has also been influencing the environment massively. ${ }^{440}$ Article 3 on the protection of the environment and ecological balance and Article 7 on the prevention and cessation of harmful effects of the 1995 Mekong Agreement are two important articles, which are connected closely with environmental protection of the Mekong river Basin. Based on these two articles, the MRC has formulated a series of strategies and policies focusing on flood and drought management, climate change adaptation, fisheries, wetland and watershed management for environmental protection and also for people's development by adapting the environmental changes and uncertainties. ${ }^{441}$

\footnotetext{
${ }^{438}$ Mauricio E. Ariasi, Thomas A. Cochrane and Vittoria Elliott, 'Modelling future changes of habitat and fauna in the Tonle Sap wetland of the Mekong' (2014) 41/2 Environmental Conservation 165, 165. ${ }^{439}$ Caio Cesar de Araujo Barbosa, John Dearing, 'Evolutionary Social and Biogeophysical Changes in the Amazon, Ganges-Brahmaputra-Meghna and Mekong Deltas’ (2016) 11 Sustainability Science 555, 558.

${ }^{440}$ R Edward Grumbine, John Dore and Jianchu Xu, 'Mekong hydropower: drivers of change and governance challenges' (2012) 10/2 Frontiers in Ecology and the Environment 91, 93.

${ }^{441}$ MRC, 'Environmental Health' (Official Website of the MRC)

<http://www.mrcmekong.org/topics/environmental-health/> accessed 02 October 2016.
} 
Biodiversity is also an important issue of nature and ecology protection. The Mekong River basin is the world's second most bio-diverse river basin, and holds approximately "2000 plant species, 430 mammal species, 1200 bird species, 800 reptile and amphibian species, and 850 fish species"; ${ }^{442443}$ additionally, there are also many species that have yet to be discovered. However, because of wetland drainage, overgrazing, mining, reservoir construction, agricultural pollution, unreasonable hunting and trade, and other related human activities, the biodiversity of the Mekong Region is at risk. ${ }^{444}$ This is reflected in the decline of the fish species, bird species, and amphibians and reptiles. ${ }^{445}$ The MRC plays an active role in improving biodiversity. For instance, an indigenous species aquaculture project has been initiated under the Fisheries Programme. This project aims to prevent the incursion of non-native species, which could harm the indigenous species and interrupt the balance of biodiversity in the region. ${ }^{446}$ Furthermore, the MRC's Basin Development Programme also gives a great deal of attention to the biodiversity issue. By using an integrated approach, the BDP Programme considers environmental impacts related to biodiversity loss, and solutions for reducing this loss. ${ }^{447}$

Wetlands protection is also a vital issue closely connected to biodiversity conservation. The wetlands of the Mekong River basin provide habitats to numerous species of flora and fauna, and are also a crucial basis for millions of rural people's lives. ${ }^{448}$ Other ecological aspects of the wetlands are also reflected by "sediment trapping, nutrient recycling and pollution removal, surface and ground water storage and carbon capture". ${ }^{449}$ Besides these aspects, the wetlands can bring benefits by providing circumstances for rice cultivation, capture fisheries, aquaculture, and

\footnotetext{
${ }^{442}$ Ibid.

${ }^{443}$ Boer, Hirsch, Johns, Saul and Scurrah (n 11) 9.

${ }^{444}$ Hoang Huu Nguyen, Paul Dargusch, Patrick Moss, Da Binh Tran, 'A review of the drivers of 200 years of wetland degradation in the Mekong Delta of Vietnam' (2016) Regional Environmental Change, 6 <http://link.springer.com/article/10.1007\%2Fs10113-016-0941-3> accessed 27 October 2016.

${ }^{445}$ MRC, 'Environmental Health' (Official Website of the MRC) <http://www.mrcmekong.org/topics/environmental-health/> accessed 02 October 2016.

${ }^{446}$ Ibid.

${ }^{447}$ Ibid.

${ }^{448}$ E. Ariasi, A. Cochrane and Elliott (n 438) 165.

${ }^{449}$ Ibid.
} 
tourism. ${ }^{450}$ In accordance with the significance of the wetlands analyzed above, the MRC's Environmental Programme and Climate Change Adaptation Initiative make decisions concerning wetlands protection more well-rounded and further-reaching, and also supply measures to combat the negative impacts of climate change. ${ }^{451}$

\subsection{Environmental Programme}

Water resources are crucial for people's lives and the ecosystem in the Mekong River basin. Although the current status of the water resources and related resources in the Mekong River basin is satisfactory, there are still a number of problems, such as a high nutrient concentration in the Mekong Delta, environmental degradation due to industrialization, and, last but not least, the impacts of climate change.

In order to maintain the balance between economic development, environmental protection and social sustainability in the Mekong region, the MRC has launched the Environment Programme, which aims to support collaboration between Member countries on environmental issues. ${ }^{452}$ This Programme is meant to facilitate the exchange of environmental and social knowledge, which should be regarded as a vital element guiding basin management and development. Furthermore, it should improve the efficiency of the environmental management cooperation by providing support in implementing the regional Procedures for Water Quality that have the objective of maintaining satisfactory water quality and promoting sustainable development. ${ }^{453}$

Because of the international connectedness of the Mekong River, the environmental issues in this region are transboundary in nature. Therefore, the Environmental Programme develops knowledge and scientific data for the whole region, and makes efforts to foster communication among Mekong Countries. The Guideline for Transboundary Environmental Impact Assessment, which sets a cross-regional

\footnotetext{
${ }^{450}$ MRC, 'Natrual Resources' (Official Website of the MRC) <http://www.mrcmekong.org/mekongbasin/natural-resources/> accessed 02 October 2016.

${ }^{451}$ MRC, 'Environmental Health' (Official Website of the MRC) <http://www.mrcmekong.org/topics/environmental-health/> accessed 02 October 2016.

${ }^{452}$ MRC, 'Environmental Programme' (Official Website of the MRC) $<$ http://www.mrcmekong.org/about-mrc/programmes/environment-programme/> accessed 02 October 2016.

${ }^{453}$ MRC, 'Procedures for Water Quality' (Official Website of the MRC) $<$ http://www.mrcmekong.org/about-mrc/mandate/procedures-for-water-quality/> accessed 02 October 2016.
} 
standard for national activities and also contributes to conflict resolution between Mekong Countries, was developed within this context. ${ }^{454}$ This Programme also provides a periodic overview of the environmental, social and economic conditions of the Lower Mekong basin called The State of Basin Report, which helps Member Countries and related stakeholders get a better understanding of the transboundary changes within the Mekong River basin. ${ }^{455}$

In addition, this Programme also focuses on fostering people's understanding of the interdependence between their daily lives and the environment. It provides test results on water quality and other related information to national agencies, and it also supplies action plans to national governments for improving regional reactions to environmental emergencies. Training and awareness kits and other materials are also available for the riparian people in their local languages. ${ }^{456}$

\subsubsection{Summary}

The natural resources of the Mekong River can bring a series of ecological benefits and play a crucial role in the social and economic development of the entire region. Therefore, the MRC's efforts to promote environmental health can be reflected not only in the environmental aspects, but also in the social and economic aspects.

The MRC has formulated several related strategies for different aspects of this topic. Firstly, biodiversity conservation is one of the important aspects, because it is a focal factor for environmental health. By implementing measures such as the Fisheries Programme and the Basin Development Programme, the MRC intends to achieve the goal of maintaining the overall biodiversity. Another related issue is wetlands protection, which is closely linked to the former issue of biodiversity based on the relationship between species and their habitats. The MRC's Environmental Programme and the Climate Change Adaptation Initiative address this issue by supplying related information and potential measures to decision makers.

\footnotetext{
${ }^{454}$ MRC, 'Transboundary EIA' (Official Website of the MRC) < http://www.mrcmekong.org/aboutmrc/programmes/environment-programme/transboundary-eia/> accessed 02 October 2016.

${ }^{455}$ MRC, 'Environmental Programme' (Official Website of the MRC) <http://www.mrcmekong.org/about-mrc/programmes/environment-programme/> accessed 02 October 2016.

${ }^{456}$ Ibid.
} 
Out of a number of Programmes, the Environmental Programme is the core Programme for environmental health. It aims to maintain the balance between the economic, environmental and social development of the region. This Programme also mentions the importance of the activities of normal residents aimed at protecting their immediate environment by providing related water information to national line agencies. This promotes regional cooperative efforts to protect the environment by contributing to the State of Basin Report, as well as by proposing a guideline for transboundary environment assessment.

\subsubsection{Hydropower}

\subsubsection{Introduction}

As a source of renewable and clean energy, hydropower is attracting more and more attention within the Mekong River basin due to increasing power demand, variable prices in international energy markets, and concerns over greenhouse gas reduction. ${ }^{457}$ However, the topic of hydropower development in the Mekong River Basin is very controversial. On the one hand, the large hydropower projects can bring a series of benefits to the riparian governments, such as reducing poverty, lowering national debts, fostering economic prosperity, and improving energy security. ${ }^{458}$ On the other hand, however, the development of hydropower also has several cumulative impacts on the environment, fisheries, and also people's livelihood in the Mekong River basin. ${ }^{459}$

The MRC goes to great lengths to avoid negative impacts across the region and to maintain the sustainability of hydropower development. These efforts are focused not only on infrastructure construction, which contributes to energy service, but also on the comprehensive effectiveness of projects based on a basin-wide perspective. ${ }^{460}$ It works with Member Countries to formulate hydropower strategies and policies,

\footnotetext{
${ }^{457}$ MRC, 'Sustainable Hydropower' (Official Website of the MRC) <http://www.mrcmekong.org/topics/sustainable-hydropower/> accessed 02 October 2016. 458 Ibid.

${ }^{459}$ Claudia Kuenzer, Ian Campbell, Marthe Roch, Patrick Leinenkugel, Vo Quoc Tuan, Stefan Dech 'Understanding the Impact of Hydropower Developments in the Context of Upstream-Downstream Relations in the Mekong river basin' (2013) 8/4 Sustainability Science 565, 565.

${ }^{460}$ MRC, 'Sustainable Hydropower' (Official Website of the MRC) <http://www.mrcmekong.org/topics/sustainable-hydropower/> accessed 02 October 2016.
} 
coordination of impact assessments, and develop reasonable measures for impact mitigation. ${ }^{461}$ The potential of hydropower in the Mekong River Basin is very high and has not been developed very well. So it creates a challenge for Mekong Countries to design effective strategies and collaborative approaches to sustainably develop hydropower. Therefore, the MRC has formulated the Initiative on Sustainable Hydropower (ISH), which focuses on fostering regional cooperation to promote sustainable management of increased hydropower projects from a basin-wide management perspective. ${ }^{462}$ This Initiative includes "drawing effectively on international experiences, developing regional technical knowledge, and sharing best practices relevant to all stages of planning" ${ }^{463}$ The Initiative is also integrated with activities of other MRC's Programmes, such as the Basin Development Plan Programme, Environment Programme, Fisheries Programme, Navigation Programme, and so forth. ${ }^{464}$ The following section introduces further details about the ISH project.

\subsection{Initiative on Sustainable Hydropower}

Due to recent demands on hydropower development and the hydropower-related impacts on different aspects of the Mekong River basin, the Initiative on Sustainable Hydropower was established by the MRC in 2008, aiming to advance regional cooperative efforts working towards sustainable management of increased hydropower projects from a basin-wide perspective. ${ }^{465}$ Based on this Initiative, the MRC connects the decisions on hydropower management of all the member countries with the aim to develop the hydropower with basin-wide integrated water resources management. In addition, the MRC supports regional consultation on mainstream hydropower development proposals through the "Procedures for Notification, Prior Consultation and Agreement (PNPCA)" set down according to the 1995 Mekong

\footnotetext{
461 Ibid.

${ }^{462}$ MRC, 'Initiative on Sustainable Hydropower' (Official Website of the MRC)

$<$ http://www.mrcmekong.org/about-mrc/programmes/initiative-on-sustainable-hydropower/> accessed 02 October 2016.

463 Ibid.

${ }^{464}$ Ibid.

${ }^{465}$ MRC, 'Initiative on Sustainable Hydropower' (Official Website of the MRC)

<http://www.mrcmekong.org/about-mrc/programmes/initiative-on-sustainable-hydropower/> accessed 02 October 2016.
} 
Agreement, which can help Member Countries better understand the risks and potential for success of these proposals. ${ }^{466}$

This Initiative provides support to regional planning by establishing knowledge platforms and networks that can help Member Countries exchange information, share experiences and cooperate on sustainable hydropower tolls and practices. ${ }^{467}$ It aims to raise awareness of sustainability in the process of hydropower decision-making. The initiative also developed the Preliminary Design Guidance for Proposed LMRB Hydropower Schemes, which furthers the exchange of best practices effectively based on regional and international experiences by designing mainstream Mekong hydropower schemes. Additionally, the Initiative also fosters strategic transboundary assessments that can supply member countries with technical advice for potential regional impacts on mainstream hydropower projects. ${ }^{468}$

Furthermore, this Initiative is also a crosscutting initiative aimed at achieving the benefits of hydropower, long-term sustainability, and mutually beneficial development from a basin-wide perspective. Its crosscutting character is reflected in several measures connecting the aspect of hydropower planning and management with other different aspects, such as environmental and socio-economic baseline information, fishery productivity, cumulative impacts of hydropower, benefit sharing and innovative finance approaches for improving sustainable outcomes to achieve stakeholder expectations etc. ${ }^{469}$

There are numbers of studies that have analyzed the social, environmental, and economic impacts from construction and operation of large dams and demonstrated the complexity of such issues. Among these academic works, there are hardly any that are both comprehensive and specifically address the gender-specific dimension of hydropower development. Interestingly, women have proven to be one of the most vulnerable groups during hydropower development. However, research on the genderrelated risks is still insufficient. ${ }^{470}$ Supported by the Deutsche Gesellschaft für Internationale Zusammenarbeit (GIZ) $\mathrm{GmbH}$, the ISH held a regional scoping

\footnotetext{
466 Ibid.

${ }^{467}$ Ibid

468 Ibid.

${ }^{469}$ Ibid.

${ }^{470}$ Ibid.
} 
workshop on Gender and Sustainable Hydropower from 20-21 June 2013 in Bangkok, Thailand. This workshop provided a platform for awareness raising and exchanging ideas. However, the MRC and its stakeholders have yet to engage in any concrete activities for improving gender-sensitive hydropower. ${ }^{471}$

This initiative is also closely deeply in the MRC's Fisheries Programme, due to the close relationship between the fish biodiversity of the hydropower development. ${ }^{472}$ Nowadays, the hydropower practitioner and regional line agencies in the Fish and Hydropower Primer are well aware of the importance of fisheries. Therefore, the ISH has supported a comprehensive review of "available fish passage technology and design parameters". The initiative has also furthered research and practice on turbine design, which should reduce fish death when fish pass downstream through turbines. ${ }^{473}$

\subsubsection{Summary}

Hydropower development plays a very complex role in the Mekong River basin, because it has both negative and positive effects on the Mekong Region. Following the 1995 Mekong Agreement, MRC has engaged in a series of efforts related to this topic to improve the hydropower development in a sustainable way from a basin-wide perspective based on close cooperation between the member countries. The MRC also established the Initiative of Sustainable Hydropower, which connects Member Countries' decisions on hydropower development with the Integrated Water resources Management. This initiative provides a platform for Member countries to exchange information and experiences, and also supports regional consultation on mainstream hydropower development proposals and transboundary environmental assessment. Under this initiative, which is treated as a crosscutting initiative, hydropower development has also been connected with other issues, such as gender, fisheries and so forth.

\footnotetext{
${ }^{471}$ Ibid.

${ }^{472}$ Guy Ziva, Eric Baran, So Nam, Ignacio Rodríguez-Iturbed and Simon A. Levina, 'Trading-off Fish Biodiversity, Food Security, and Hydropower in the Mekong River Basin' (2012) 109 Proceedings of the National Academy of Science of the United State of America 5609, 5610-5611.

${ }^{473}$ MRC, 'Initiative on Sustainable Hydropower' (Official Website of the MRC) <http://www.mrcmekong.org/about-mrc/programmes/initiative-on-sustainable-hydropower/> accessed 02 October 2016.
} 


\subsubsection{Water Quality}

\subsubsection{Introduction}

Water quality is always an important issue when talking about water resources protection and management. In the Mekong River Basin, it is also a crucial element in different aspects: First of all, good quality of water is the basis for riparian people's lives and health. ${ }^{474}$ Moreover, as an indispensable element of the ecosystem, the quality of the water also plays a vital role in ecological balance and sustainability. And from the aspect of national economic development, water quality affects the agricultural irrigation, aquaculture, and fisheries, which can be connected with food security and other related aspects. ${ }^{475}$

Although, in recent time, the quality of the water resources in the Mekong River Basin is quite acceptable, they are still threatened by some elements, such as pollution coming from industrialization, saltwater intrusion, and so forth. This bad water quality will lead to a series of negative consequences, such as decreasing the quality of people's daily lives, hampering agricultural and fishery productivity, affecting soil quality, and causing ecosystem imbalance. ${ }^{476}$ In January of 2011, the MRC formulated the Procedures for Water Quality, which aims to ensure that the water resources are used in a reasonable and equitable way, and also maintain the water at a quality level capable of meeting the needs of the Member Countries. ${ }^{477}$ The MRC's Environment Programme has also facilitated the implementation of these Procedures. ${ }^{478}$

\footnotetext{
${ }^{474}$ Chea R, Grenouillet G, Lek S, 'Evidence of Water Quality Degradation in Lower Mekong Basin Revealed by Self- Organizing Map' (2016) 11/1: e0145527. PLoS ONE, 1-2 <http://journals.plos.org/plosone/article/asset?id=10.1371/journal.pone.0145527.PDF> accessed 27 October 2016.

475 Ibid.

${ }^{476}$ Chea R, Grenouillet G, Lek S (n 474) 13-15.

${ }^{477}$ Procedures for Water Quality [2011] Mekong River Commission, Preamble <http://www.mrcmekong.org/assets/Publications/policies/Procedures-for-Water-Quality-councilapproved260111.pdf> accessed 02 October 2016.

${ }^{478}$ MRC, 'Environmental Programme' (Official Website of the MRC) $<$ http://www.mrcmekong.org/about-mrc/programmes/environment-programme/> accessed 02 October 2016.
} 


\subsection{Procedures for Water Quality}

Based on the 1995 Mekong agreement, the MRC Council Resolution on Water Utilization Programme in 1999, and the establishment of the Technical Drafting Group 6 for the Procedures for Water Quality, the MRC formulated the Procedures for Water Quality in January of 2011. These Procedures aim at reasonable and equitable utilization of water resources, and keeping the water resource capable of being used to the Member Countries' benefit. ${ }^{479}$

The objective of the Procedures is "to establish a framework for the maintenance of acceptable and good water quality to promote sustainable development of the Mekong River Basin". ${ }^{480}$ While Procedures should be implemented based on the principles of the 1995 Mekong Agreement, there are also three additional principles, namely cost effectiveness, accountability, and transparency. ${ }^{481}$ The scope of the Procedures has already been expressed: to maintain the water quality of the Mekong River mainstream. Therefore, all of the Member Countries should make efforts based on the 1995 Mekong Agreement to maintain the mainstream water quality. Because of the connection between the mainstream water quality and the tributaries' water quality, the Member Countries should also take the water quality in Mekong River's tributaries into account. ${ }^{482}$

In the interest of implementing the Procedures as effectively as possible, the Member Countries should make efforts to maintain the water quality according to the principles of the Procedures. The existing water quality monitoring and assessment programs should be strengthened, and new programs should also be established, where necessary. The MRC Joint Committee should uphold the Technical Guidelines for implementation of the Procedures. The Member Countries should also conduct research on improving the Technical Guidelines for effective implementation of the Procedures. ${ }^{483}$ Given an emergency water quality incident, the Member countries should take measures based on Articles 7 and 10 of the 1995 Mekong Agreement, Rule 22 of the Rules of Procedures of the MRC Joint Committee, and other relevant

\footnotetext{
${ }^{479}$ Procedures for Water Quality (n 477) Preamble.

${ }^{480}$ Procedures for Water Quality (n 477) Objective.

${ }^{481}$ Procedures for Water Quality (n 477) Principles.

${ }^{482}$ Procedures for Water Quality (n 477) Scope.

${ }^{483}$ Procedures for Water Quality (n 477) Implementation, Water Quality Management.
} 
procedures. ${ }^{484}$ The Procedures also mention that Member Countries should endeavor to raise public awareness of water quality maintenance and to encourage public participation in water quality issues within the Mekong Region. ${ }^{485}$

\subsubsection{Summary}

Water quality is an issue that absolutely must be taken into consideration by water resources management efforts in the Mekong River Basin. It can have a massive influence on several core aspects of basin development, such as people's health, regional fisheries, and ecosystem balance. The MRC has therefore formulated the Procedures for Water Quality that aim to establish a framework for member countries to maintain the water quality of the Mekong River and improve basin-wide sustainable development. The Procedures establish concrete measures for water quality management and also give suggestions for how to deal with emergency situations. Moreover, the Procedures emphasize the importance of raising public awareness and improving public participation. Despite all of this, it should be clear that the Procedures for Water Quality still represent a very abstract framework that is difficult to apply to current water quality risks and threats.

\subsubsection{Fishery}

\subsubsection{Introduction}

Fishery in the Mekong Region is famous the world over and plays a vital role in riparian people's livelihood. Fishery provides the Mekong's people not only with an occupation but also a source of nutrition. ${ }^{486}$ It is predicted that the population of the Mekong Region will grow to over 100 million by 2025. Therefore, the demand on fishery will also increase and the productivity of fisheries then will become a crucial element for regional development. ${ }^{487}$ Fishery in the Mekong consists of capture fishery and aquaculture fishery, both of which amount to approximately the same productivity. In Cambodia, fishery accounts for about 12 percent of GDP, and in Lao

\footnotetext{
${ }^{484}$ Procedures for Water Quality (n 477) Emergency Water Quality Situation, Water Quality Management.

${ }^{485}$ Procedures for Water Quality (n 477) Public Participation, Water Quality Management.

${ }^{486}$ Ziva, Baran, Nam, Rodríguez-Iturbed and A. Levina (n 472) 5609.

${ }^{487}$ MRC, 'Fisheries' (Official Website of the MRC) <http://www.mrcmekong.org/topics/fisheries/> accessed 02 October 2016.
} 
PRD 7 percent of GDP. Although fishery is less important for local economies in Thailand and Vietnam, it still provides approximately 750 million US dollars to their respective GDPs per year. ${ }^{488}$

Because the fishery sector relies heavily on water resources, several aspects of the development of other water-related sectors in the Mekong Region therefore become threats to fishery, such as irrigated agriculture, domestic water supply, and industrial use. The pollution from industry also affects fishery, because the wastewater contaminates the fish. ${ }^{489}$ Moreover, hydropower development projects will also bring related impacts for fishery, such as habitat loss and barriers to fish migration. ${ }^{490}$

The MRC has formulated a long-term Fishery Programme, and it plays a vital role in recording and raising awareness of the importance of fishery for regional people's livelihood and food security. ${ }^{491}$ This Programme aims to protect fishery by using an integrated approach that aligns with other sectors. By cooperating with the Member Countries, the MRC is making an effort to share technical information on fishery management and raise awareness of the sector's significance for the Mekong's environment and riparian people's lives. ${ }^{492}$

\subsection{Fishery Programme}

The aim of this Programme is "to support Mekong fisheries stakeholders to use the basin's fisheries resource effectively and sustainably that would eradicate poverty while protecting the environment". ${ }^{493}$ To achieving this goal, this Programme has three strategies: Firstly, it tries to deliver knowledge and improve understanding of key issues that affect fishery. Secondly, policies and institutions should be improved

\footnotetext{
${ }^{488}$ Ibid.

${ }^{489}$ Ibid.

${ }^{490}$ Ziva, Baran, Nam, Rodríguez-Iturbed and A. Levina (n 472) 5609-5610.

${ }^{491}$ MRC, 'Fisheries' (Official Website of the MRC) <http://www.mrcmekong.org/topics/fisheries/> accessed 02 October 2016.

492 Ibid.

${ }^{493}$ MRC, 'Fisheries Programme' (Official Website of the MRC) $<$ http://mrcmekong.mrcdev.info/about-mrc/programmes/fisheries-programme/> accessed 02 October 2016.
} 
for better fishery management and development. Thirdly, the fishery management capacities of government agencies and fisher communities will be strengthened. ${ }^{494}$

This Programme uses newsletters, brochures, and videos to keep the public's awareness of fishery up-to-date. It also supplies advice focusing on key issues and threats relating to fishery by publishing scientific studies and technical reports and making them available to special audiences of fishery and water managers, scientists, and policy-makers. It also promotes the regional exchange of information and experiences from various stakeholders through regular events, such as advisory meetings and technical symposia. ${ }^{495}$

It is very important to link people's knowledge with actions for the sustainable Mekong fishery development. Therefore, this Programme has spent more than ten years educating people and helping them to realize the importance of the Mekong fishery. For example, fishermen are encouraged to proactively participate in agency's judgements and decisions. Furthermore, there are also endeavors to integrate fishery concerns into agricultural, nutritional, and natural resource management issues. ${ }^{496}$

There are also measures that focus on improving people's fishery management skills and capacities. Due to its diversity and scope, it is hard for government to manage fishery very effectively. Normally, fishery management is based on traditional knowledge from fisher communities, but local information should be improved and updated as times change and technology improves. Therefore, one task of the Fishery Programme is to allocate scientists from a governmental level to support communities' fishery management activities. Another related task is to establish fishermen groups and organizations that can facilitate improvement of their capacity to plan and execute sustainable fishery management. ${ }^{497}$

Last but not least, the Mekong fishery resources and other related resources for the existence of fish are a basin-wide interactive system. Many kinds of Mekong fish are migratory, and some cross boundaries to spawn. Because of this characteristic of fishery resources, fishery management and sustainable utilization must be basin-wide. The Fishery Programme has attempted to address this issue in two respects. On the

\footnotetext{
${ }^{494}$ Ibid.

495 Ibid.

${ }^{496}$ Ibid.

${ }^{497}$ Ibid.
} 
one hand, it has developed a strategy aimed at strengthening cooperation between national fishery agencies. On the other hand, it has also developed transboundary fishery management activities in coordination with fishing regulations between neighboring provinces in different countries. ${ }^{498}$

\subsubsection{Summary}

Fishery plays a very important role in the Mekong River basin, because it is very closely linked to riparian people's livelihoods and also to national economic development. Nowadays, fishery in the Mekong region has been affected by several elements, such as basin development projects, development of other water-related sectors, and pollution from industrialization. Based on the aim of creating sustainable fisheries in the Mekong River Basin, the MRC established the Fishery Programme to raise people's awareness of fishery's importance and also improve people's livelihoods and regional food security. This Programme also takes measures to improve fishermen's skills and capacity for fishery management. Furthermore, it also makes efforts to strengthen cooperation to address cross-border fisheries issues.

\subsubsection{Conclusion of the Mekong Water Regime's Function}

With the help of the MRC, many functions of the Mekong water regime have been implemented in different aspects. These functions all follow the focus of the Mekong water regime, that is, the sustainable development of the Mekong River basin. Sustainable development has a pluralist understanding that includes not only economic sustainable development, but also social and environmental sustainable development. These three elements combine together to formulate a comprehensive understanding of sustainable development. Additionally, this region is still in a developing state, and the economic growth is the most urgent demand for solving a series of problems, such as poverty alleviation. Hence, the functions of the Mekong water regime involve different aspects of sustainable development and also emphasize economic development very much.

On the one hand, sustainable development can be reflected by 10 main functions: integration, people, agriculture, flood and drought, climate change, navigation, environmental health, hydropower, water quality, and fishery. These 10 functions contain nearly all water resources-relevant sectors in the Mekong River basin, and

\footnotetext{
${ }^{498}$ Ibid.
} 
hence can foster sustainable development very comprehensively. On the other hand, all functions of the regime also aim to achieve the goal of economical growth and poverty reduction. These functions do not merely focus on the pure environmental aim of protecting the basin ecosystem and water resources. For instance, the function of the fishery focuses not only on fish species conservation, but also on maintaining a certain level of income from fish capture. To some extent, these functions care more about economical growth than the environmental and social aspects.

Unfortunately, the implementation of the Mekong water regime's functions has not been very effective or efficient due to the weakness and abstractness of the only legal basis, namely the 1995 Mekong Agreement. Despite this fact, these functions still affect some aspects of the development of the Mekong River basin, such as public participation, the trans-boundary EIA, the data information collection, and so forth.

Furthermore, functions of the Mekong water regime have also been affected by some regional circumstances, such as regional climate and geography. For instance, the regional climate creates obvious wet and dry seasons in the Mekong River basin, and hence the flood and drought function must also be adjusted to this climate characteristic. The geography creates a huge potential for hydropower, and hydropower can therefore become a crucial source of economic growth. Lastly, the function of hydropower also focuses not only on the project's impacts on the ecosystem, but also on the economic benefits that hydropower project brings.

\subsection{Comparison with the Rhine River Basin}

\subsubsection{Introduction to the International Legal Water Regime in the Rhine River}

\section{Basin}

The Rhine River originates in the Swiss Alps and flows into the North Sea in the Netherlands. It plays a crucial role in the economic and cultural development of Middle Europe. ${ }^{499}$ There are about 58 million people from nine countries living in the

\footnotetext{
${ }^{499}$ Stefan Lindemann, 'Water Regime Formation in Europe: A Research Framework with Lessons from the Rhine and Elbe River Basins' (2006) Available at SSRN, 16 $<$ https://ssrn.com/abstract=925653> or <http://dx.doi.org/10.2139/ssrn.925653> accessed 27 October 2016.
} 
Rhine river basin, and therefore the utilization of the Rhine is more intensive and varied than other European rivers. ${ }^{500}$

The members of the International Commission for the Protection of the Rhine (ICPR) are Switzerland, France, Germany, Luxemburg, the Netherlands, and the European Commission, which cooperate with Austria, Liechtenstein and the Belgian region of Wallonia as well as Italy to harmonize many interests involving utilization and protection of the Rhine area. The Commission focuses on sustainable development of the Rhine, its alluvial areas, and maintaining an acceptable state of all of its waters, including the Rhine's tributaries but excluding brooks, lakes, wetlands, and groundwater in the Rhine River basin. This international cooperative organization is also under the guidance of the Water Framework Directive and the Floods Management Directive of the EU; together, these two legal instruments and the 1999 Convention on the Protection of the Rhine comprise the Rhine international legal water regime. ${ }^{501}$ As the institutional organization of this legal water regime, the ICPR has taken numerous measures and become a model for many other river basins over the last decade. ${ }^{502}$

As a model legal water regime for international river basin management, the Rhine legal water regime has also become the author's first choice for comparison with the Mekong River legal water regime. The Rhine water regime is a well-developed water regime, and has already got many achievements. Its experiences are quite important for the other water regime's development. Also, the EU plays a special role for this regime. Therefore, according to this comparison we could also see the differences between these two water regimes of different historical and political background. Based on this comparison, the author would like to generate inspiration for future development of the Mekong water regime.

\subsubsection{Evolutionary History of the Rhine Water Regime}

Before 1950, increasing pollution to the Rhine brought about by industrialization became a vital reason for international cooperation to improve it. On 11 July 1950,

\footnotetext{
${ }^{500}$ ICPR, 'The Rhine' (Official Website of the ICPR) < http://www.iksr.org/en/rhine/index.html> accessed 02 October 2016.

${ }^{501}$ ICPR, ‘About Us' (Official Website of the ICPR) < http://www.iksr.org/en/internationalcooperation/about-us/index.html> accessed 02 October 2016.

${ }^{502}$ Ibid.
} 
Germany, France, Luxemburg, the Netherlands and Switzerland founded the ICPR, which aimed to "analyze the pollution of the Rhine, to recommend water protection measures, to harmonize monitoring and analysis methods, and to exchange monitoring data." ${ }^{503}$ In 1963, the governments of Germany, France, Luxemburg, Netherlands, and Switzerland signed the "Convention on the International Commission for the Rhine Against Pollution" in Bern. This Convention aimed to keep the Rhine clean, improve its current state and avoid more contamination. This was an important step towards making international water protection legally binding in the Rhine region. ${ }^{504}$ One year later, a permanent international secretariat was established in Koblenz, Germany, to coordinate the cooperation between the parties. Based on this Convention, the members made efforts to build an international monitoring network. ${ }^{505}$

By the end of the 1960s, the water quality of Rhine was still inadequate. In June 1969, there was a severe chemical accident that caused the death of many fish and raised the riparian governmental and public awareness on the pollution problem in the Rhine. ${ }^{506}$ The $1^{\text {st }}$ Conference of Rhine Ministers was held in 1972 and gathered together the Ministers in charge of environmental protection from the various riparian countries. At the next meeting in Bonn the following year, they decided to allow the ICPR to draft a Chemical Convention and a Chlorides Convention. These two Conventions were signed in December of 1976 in Bonn, as well as an additional protocol to the Bern Convention that was signed to confirm the European Economic Community

\footnotetext{
${ }^{503}$ ICPR, 'History' (Official Website of the ICPR) < http://www.iksr.org/en/internationalcooperation/about-us/history/index.html> accessed 02 October 2016.

${ }^{504}$ ICPR, 'Conceiving cooperation' (Official Website of the ICPR)

<http://www.iksr.org/en/international-cooperation/about-us/history/conceiving-cooperation/index.html> accessed 02 October 2016.

505 Ibid.

${ }^{506}$ ICPR, 'Increasing confidence' (Official Website of the ICPR)

<http://www.iksr.org/en/international-cooperation/about-us/history/increasing-confidence/index.html> accessed 02 October 2016.
} 
becoming a party to ICPR. Thanks to a series of measures, the water quality of the Rhine improved considerably. ${ }^{507}$

In 1986, the Sandoz accident caused firewater mixed with as many as 30 tons of pesticides to flow into the Rhine, leading to the widespread death of aquatic flora and fauna along hundreds of kilometers of the Rhine. As a consequence, the "Rhine Action Programme" was established, which focused on cutting the quantities of 40 dangerous chemicals in half within 10 years and creating a clean living environment for salmon. ${ }^{508}$ Thanks to the Rhine Action Programme, the pollution was brought under control and the ecosystem of the Rhine was improved, including better water quality and a healthier environment for flora and fauna. In 1993 and 1995, respectively, there were two floods that promoted the formulation of Flood Action Plans. Finally, in 1999, based on a comprehensive international water management integrating different aspects of Rhine water resources that had been in development since 1987, the new Convention on the Protection of the Rhine was formulated. ${ }^{509}$ In November of 1993, based on the Maastricht Treaty, environmental and water protection became objectives of the European Union for the first time; water protection by the ICPR then became an example for drafting of EU directives related to the river basin's environment and water protection. The objective of the EU Framework Directive, that entered into force on 22 December 2000 and is legally binding for all EU Member States, is to achieve an acceptable state for all water bodies by $2015 .{ }^{510}$ In January 2001, Switzerland agreed to support cooperation between EU Member States in the ICPR in accordance with national laws. During the same period, the Rhine Coordinating Committee was established within the ICPR,

\footnotetext{
${ }^{507}$ ICPR, 'Increasing confidence' (Official Website of the ICPR)

<http://www.iksr.org/en/international-cooperation/about-us/history/increasing-confidence/index.html> accessed 02 October 2016.

${ }^{508}$ ICPR, 'The turning point: the Sandoz accident' (Official Website of the ICPR) <http://www.iksr.org/en/international-cooperation/about-us/history/the-turning-point-the-sandozaccident/index.html> accessed 02 October 2016.

${ }^{509}$ ICPR, 'Integration and example' (Official Website of the ICPR) <http://www.iksr.org/en/international-cooperation/about-us/history/integration-andexample/index.html> accessed 02 October 2016.

${ }^{510}$ ICPR, 'The Rhine in a European context' (Official Website of the ICPR) <http://www.iksr.org/en/international-cooperation/about-us/history/the-rhine-in-a-europeancontext/index.html> accessed 02 October 2016.
} 
integrating Liechtenstein, Austria and Belgium (Wallonia). ${ }^{511}$ A Programme to further the sustainable Development of the Rhine until 2020 was launched in 2001. In the years following, the EC Groundwater Directive, the EU Flood Risk Management Directive, the EU Directive on Environmental Water Quality Standards and other water-related policies entered into force. Rhine water resource and environmental protection thus entered into the "EU era". 512

Thanks to the international cooperation under the Rhine legal water regime, the water quality and ecosystem of the Rhine and its many tributaries improved in many respects. $96 \%$ of the riparian population is served by a wastewater treatment plant, and many industrial plants have wastewater treatment plants as well. The number of species of flora and fauna has increased. Floodplains have been reactivated by reconnecting Oxbow lakes and carrying out other related measures. As for negative impacts from floods, many efforts have been made to reduce them and almost all flood prevention measures have been implemented. ${ }^{513}$ Today, there are also several challenges for the Rhine legal water regime, including flood prevention, ecosystem improvement, climate change-related water management problems, and reduction of pollutants from agriculture as well as urban wastewater. ${ }^{514}$

\subsubsection{Legal Basis: Convention, EU Water Framework Directive, Floods Directive}

\subsection{The Convention on the Protection of the Rhine}

The Convention on the Protection of the Rhine is a vital legal basis for international cooperation to protect the Rhine within the ICPR. On 12 April 1999, five riparian countries on the Rhine, including France, Germany, Luxembourg, Netherlands, Switzerland, and the EU signed this Convention to formally confirm their commitment to protect the valuable character of the Rhine, its banks and

\footnotetext{
511 Ibid.

512 Ibid.

${ }^{513}$ ICPR, 'Success' (Official Website of the ICPR) < http://www.iksr.org/en/internationalcooperation/about-us/challenges/success/index.html> accessed 02 October 2016.

${ }^{514}$ ICPR, 'Challenges' (Official Website of the ICPR) < http://www.iksr.org/en/internationalcooperation/about-us/challenges/index.html> accessed 02 October 2016.
} 
floodplains. ${ }^{515}$ This Convention also replaced the treaty of Bern signed in 1963, as well as the Chemical Conventions signed in 1976. The international office for the implementation of this Convention, the international secretariat of the ICPR, is located in Koblenz, Germany. ${ }^{516}$

There are five objectives in this Convention. ${ }^{517}$ The first objective is to ensure that the Rhine ecosystem is developed in a sustainable way. To maintain the Rhine water at a quality level high enough to be used as a drinking water supply for riparian populations is the second objective. Another objective is to improve the quality of Rhine sediments. Given this improvement, the dredge material can be deposited without causing any environmental harm. The fourth objective is to establish a comprehensive flood prevention and protection system that takes ecological requirements into consideration. ${ }^{518}$ The last objective is relief of the North Sea, ${ }^{519}$ and this objective gives the restoration of the Rhine a more international dimension. ${ }^{520}$ Among other objectives, the focal elements of the Convention are the preservation, improvement and sustainable development of the Rhine ecosystem. ${ }^{521}$ The Rhine is not only considered an important European navigation passage, but also integral element for other uses as well..$^{522}$

\footnotetext{
${ }^{515}$ ICPR, 'Convention on the Protection of the Rhine' (Official Website of the ICPR)

<http://www.iksr.org/en/international-cooperation/legal-basis/convention/index.html> accessed 02

October 2016

516 Ibid.

${ }^{517}$ Convention on the Protection of the Rhine [1999] TIAS 11085; UNTS 1506/157, art 3

<http://www.iksr.org/fileadmin/user_upload/Dokumente_en/convention_on_tthe_protection_of_the_r hine.pdf $>$ accessed 26 October 2016.

518 Ibid.

${ }^{519}$ Ibid.

${ }^{520}$ Ibid.

${ }^{521}$ Convention on the Protection of the Rhine (n 517) art 2.

${ }^{522}$ ICPR, 'Convention on the Protection of the Rhine' (Official Website of the ICPR)

$<$ http://www.iksr.org/en/international-cooperation/legal-basis/convention/index.html> accessed 02

October 2016.
} 


\subsection{The European Water Framework Directive}

In 2000, the European Water Framework Directive (WFD) entered into force, aiming to implement holistic water protection in the European river districts. ${ }^{523}$ The WFD treats a river basin district as an entity. ${ }^{524}$ Based on WFD, the European water legislation has been modernized and harmonized, and meanwhile, the WFD requires transboundary integrated assessment and management for the international river basin. It defines what is considered "acceptable" chemical and ecological status, and set 2015 as the deadline for achieving this status in all European water bodies. ${ }^{525}$

The objective of the WFD is the good status of groundwater and surface waters, which consist of lakes, running waters, transitional and coastal waters up to the baseline one nautical mile off the coast. ${ }^{526}$ Since the implementation of the WFD, pollution control within the Rhine has gone into a new era. ${ }^{527}$ To maintain the good status of waters, the EU Member States are making suitable and effective efforts to improve water bodies. All uses that affect the state of water bodies are being taken into consideration, which includes industry, navigation, hydropower development, and agriculture. ${ }^{528}$ Based on this target of achieving good status, pollution reduction has also become a focal issue in the Rhine River district. The interaction between the river and its alluvial area and free fish migration along the Rhine also need to be improved.

\footnotetext{
${ }^{523}$ ICPR, 'European Water Framework Directive' (Official Website of the ICPR)

$<$ http://www.iksr.org/en/international-cooperation/legal-basis/european-water-frameworkdirective/index.html> accessed 02 October 2016.

${ }^{524}$ Directive 2000/60/EC of the European Parliament and of the Council of 23 October 2000 establishing a Framework for Community Action in the Field of Water Policy [2000] OJ L 327/1 (2000), art $2<$ http://eurlex.europa.eu/LexUriServ/LexUriServ.do?uri=CELEX:32000L0060:EN:HTML> accessed 26 October 2016.

${ }^{525}$ Erik Mostert, 'The European Water Framework Directive and water management research' (2003) 28 Physics and Chemistry of the Earth 523, 523.

${ }^{526}$ WFD (n 524) art 1 and 2.

${ }^{527}$ ICPR, 'Targets and principles of the Water Framework Directive' (Official Website of the ICPR) <http://www.iksr.org/en/international-cooperation/legal-basis/european-water-frameworkdirective/targets-and-principles/index.html> accessed 02 October 2016. ${ }^{528}$ Ibid.
} 
Based on the WFD, the watershed has been treated as an entire entity, which requires the obligation of waters management also to be cross-boundary; however, this is also one of the greatest opportunities and challenges. The extent of the protection management covers not only the mainstream, but also its watershed that includes entire surface and underground drainage area. ${ }^{529}$ Another new aspect of the WFD is that recovery of costs for drinking water supply and wastewater discharge has, for the first time, been included in an EU-wide directive. ${ }^{530531}$ The public participation is also an emphasis of the WFD. The stakeholder groups represent the entire range of pressures on water bodies, and play an important role in water bodies' protection. ${ }^{532}$ As a legal basis of the Rhine water regime, among other targets of the WFD the environmental targets are the critical focus because they are the basis for the framework for sustainable development and management of the Rhine and establishing a high level of protection for the water environment. ${ }^{533}$

\subsection{The Floods Directive}

Another crucial legal basis for the Rhine water regime is the EU Directive on the Assessment and Management of Flood Risks, which entered into force on 26 November 2007 and aims at "the reduction of the adverse consequences for human health, the environment, cultural heritage and economic activity associated with floods in the Community." 534 The 14th conference of Rhine Ministers instructed the ICPR to support the coordination of the implementation of the Floods Directive in the Rhine River basin district. The Action Plan on Floods set down by ICPR also became

\footnotetext{
${ }^{529}$ Ibid.

${ }^{530}$ Julia Martin-Ortega, Giacomo Giannoccaro and Julio Berbel, 'Environmental and Resource Costs Under Water Scarcity Conditions: An Estimation in the Context of the European Water Framework Directive' (2011) 25 Water Resources Management 1615, 1616.

${ }^{531}$ WFD (n 524) art 4 and 9.

${ }^{532}$ Mostert (n 525) 526.

${ }^{533}$ ICPR, 'Environmental targets' (Official Website of the ICPR)

<http://www.iksr.org/en/international-cooperation/legal-basis/european-water-frameworkdirective/environmental-targets/index.html> accessed 02 October 2016.

${ }^{534}$ Directive of the European Parliament and of the Council (EC) 2007/60 on the assessment and management of flood risks [2007] OJ L 288/27, art $1<$ http://eur-lex.europa.eu/legalcontent/GA/TXT/?uri=celex:32007L0060> accessed 26 October 2016.
} 
a model for the same issues by drafting the Floods Directive. ${ }^{535}$ Additionally, public participation is planned, and Between 22 December 2014 and 22 June 2015 the draft of the "Flood Risk Management Plan for the International River Basin District Rhine" was available for public information and participation. ${ }^{536}$ The plans and measures of the Floods Directive will also be coordinated with the WFD in future. The Floods Directive takes a three-phase approach. The first phase focuses on a preliminary flood risk assessment that was planned to be finished at the end of 2011. Maps of flood hazards and flood risks were planned to be finished at the end of 2013, which is the second phase of the approach. The third phase of the approach is that, by the end of 2015, the plan of the flood risk management needs to be formulated.

\subsubsection{Institutional Organization}

The institution of the International Commission on the Protection of the Rhine consists of three main components: the Plenary Assembly, the Strategy Group, and the Secretariat. The Plenary Assembly is organized annually, together with the Coordinating Committee. The Strategy Group contains different working groups that are either permanent or fixed-term mandated and are supported by expert groups when dealing with technical questions. The working groups provide information to Strategy Group, and the Strategy Group provides related information to the Plenary Assembly and the Coordination Committee, forming a vital basis for decisionmaking. ${ }^{537}$ The Secretariat prepares the contents of all meetings and offers language support. It is responsible for public relations and contacting experts and interested persons. ${ }^{538}$ The informal Rhine Coordinating Committee was created in 2001 to support the coordination in the international Rhine river basin district required within the scope of the implementation of the Water Framework Directive and Floods

\footnotetext{
${ }^{535}$ ICPR, 'Directive on the Assessment and Management of Flood Risks' (Official Website of the ICPR) <http://www.iksr.org/en/floods-directive/index.html> accessed 26 October 2016.

${ }^{536}$ ICPR, 'Public participation', Official Website of the ICPR) < http://www.iksr.org/en/floodsdirective/public-participation/index.html> accessed 26 October 2016.

${ }^{537}$ ICPR, 'Organisation' (Official Website of the ICPR) < http://www.iksr.org/en/internationalcooperation/about-us/organisation/index.html> accessed 02 October 2016.

${ }^{538}$ ICPR, 'Secretariat' (Official Website of the ICPR) <http://www.iksr.org/en/internationalcooperation/about-us/secretariat/index.html> accessed 02 October 2016.
} 
Directive. ${ }^{539}$ Due to the fact that not all states in the Rhine catchment are parties to the Convention on the Protection of the Rhine, the cooperation between the ICPR and the Coordination Committee has also become an important element for decisionmaking. ${ }^{540}$ Additionally, in 1972, the ministers, which are in charge of overseeing water protection by the contracting parties, met and decided on the commitments of the member states, and also provided orders to the Commission ${ }^{541}$ : "Conferences of Rhine Ministers decide on important political issues. Their decisions are binding for the Governments Concerned." ${ }^{542}$ The parties of the Commission include Germany, France, Luxemburg, Netherlands, Switzerland and the European Community. ${ }^{543}$ Belgium, Liechtenstein, and Austria are observer states. In addition to these, there are two other kinds of observers as well: intergovernmental organizations and nongovernmental organizations. ${ }^{544}$

\subsubsection{Summary and Assessment of the Rhine International Legal Water Regime}

The stability of the institution of the Rhine water regime is a vital basis for opportunities to improve cooperation, build mutual trust, and to come up with further criteria for improvement. Thanks to the ICPR, the riparian countries have been connected to each other for many decades ${ }^{545}$ Related agricultural and spatial planning for adjusting the water policies have been formulated at both the national and subnational levels. This regime allows governments at lower levels to be involved in the

\footnotetext{
${ }^{539}$ Nathalie Plum, Anne Schulte-Wülwer-Leidig 'From a sewer into a living river: the Rhine between Sandoz and Salmon' (2014) 729 Hydrobiologia 95, 96.

540 ibid.

${ }^{541}$ ICPR, 'Conferences of ministers' (Official Website of the ICPR)

<http://www.iksr.org/en/international-cooperation/conferences-of-ministers/index.html> accessed 02

October 2016.

542 ibid.

${ }^{543}$ Plum, Schulte-Wülwer-Leidig (n 539) 96.

${ }^{544}$ ICPR, 'Observers' (Official Website of the ICPR) < http://www.iksr.org/en/internationalcooperation/about-us/observers/index.html> accessed 02 October 2016.

${ }^{545}$ G.T. (Tom) Raadgever, Erik Mostert, Nicole Kranz, Eduard Interwies and Jos G. Timmerman, 'Assessing Management Regimes in Trans-boundary River Basins: Do They Support Adaptive Management?' (2008) 13 Ecology and Society, Assessment of the Regime in the Rhine Basin, 10 < http://www.ecologyandsociety.org/vol13/iss1/art14/> accessed 29 September 2016.
} 
implementation of international and national policies. ${ }^{546}$ NGOs, citizens, and the scientific community are also involved in water resource management in different aspects. The cooperation and organization between different stakeholders in the Rhine river basin has been established and has already reached a very high level. Public participation in the decision-making process and information assessment is well developed in all riparian states. ${ }^{547}$

The legal instruments originate directly from the framework of the ICPR are mainly related to institutional issues and pollution control. There are also some non-legally binding documents that include contents about water quality, ecology protection, and flood management, such as the Rhine Action Plan. At the EU level, the Water Framework Directive contains many provisions for water quality, ecology, and water management process, which influence the Rhine water regime to a great extent. ${ }^{548}$ These international law and policy make it possible to adapt a holistic system of national and lower-level laws, and periodic review of this adaptation is to some extent compulsory. ${ }^{549}$ Several soft instruments of the ICPR include numerous relevant measures, such as its flood policy. These instruments are normally implemented on a long-term basis and without legal sanctions for non-compliance. ${ }^{550}$

The member states of the ICPR cooperate with each other to exchange data and interests, carry out research and communicate their different perspectives. The ICPR broadcasts related information chiefly via its official website, and legal obligations to make information accessible have been formulated at different levels. ${ }^{551}$ The ICPR's working groups produce information that is reflected in the ICPR's policies, and national governments and NGOs both participate in the production of information by the working groups. It took a long time before related information entered national and trans-boundary policy debates. ${ }^{552}$ The riparian countries finance the work of ICPR and also the implementation of its policies. Therefore, the riparian countries make all vital decisions and do not rely on third parties. At the national level, the public

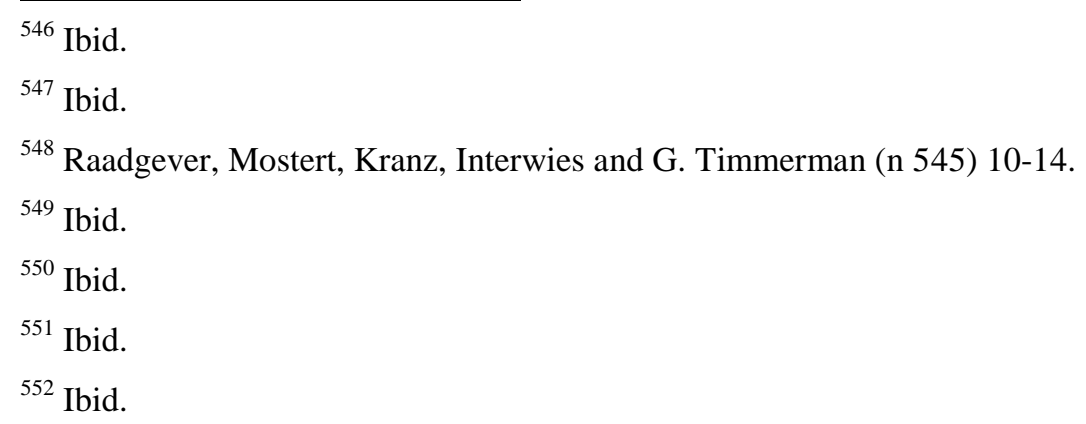


resources finance water management issues, and the costs of water supply and wastewater treatment are recovered from the users. ${ }^{553}$

\subsubsection{Functional Comparison}

\subsubsection{Integration}

\subsection{Introduction of the Integration in Rhine}

The integration in the Rhine river basin means the integration of different interests of uses and efforts to protect the Rhine, which aims to maintain the good status of its water bodies. The WFD has stated that this "good status", which entails a perfect ecological and chemical state of the Rhine's water bodies, is its objective, thereby creating a new era for pollution control in the Rhine river district. ${ }^{554}$ According to this goal, the EU Member states are making efforts to achieve a cessation of deterioration. All uses of the Rhine must be taken into consideration, such as uses by industry, navigation, hydropower development, fisheries, and agriculture. ${ }^{555}$ Additionally, the good status of the water bodies also includes the good ecological status of the Rhine, which relates to habitat protection, biodiversity conservation, flood control, and pollution control. Therefore, this goal is a goal based on the integration of several aspects of different interests. In 2004, based on the survey required by the European Water Framework Directive, nine states in the Rhine river basin district analyzed the uses of water bodies to assess which uses present a threat to the good status, and made a forecast about future development of the Rhine. ${ }^{556}$ Decisions on protection measures must consider how the environmental target can be reached at optimal cost efficiency, and these considerations may be used for limiting certain uses. ${ }^{557}$

\footnotetext{
553 Ibid.

${ }^{554}$ ICPR, 'Targets and principles of the Water Framework Directive' (Official Website of the ICPR) $<\mathrm{http}$ ///www.iksr.org/en/international-cooperation/legal-basis/european-water-frameworkdirective/targets-and-principles/index.html> accessed 02 October 2016.

${ }^{555}$ ICPR, 'Uses' (Official Website of the ICPR) <http://www.iksr.org/en/uses/index.html> accessed 02 October 2016

${ }^{556}$ ICPR, 'Inventory' (Official Website of the ICPR) <http://www.iksr.org/en/water-frameworkdirective/inventory/index.html> accessed 27 October 2016.

${ }^{557}$ Ibid.
} 
The River Basin Management Plan, which established long-term tasks for states in the Rhine river basin district, was drafted based on the WFD in $2015 .{ }^{55859}$ The first task is to rebuild the biological continuity and to improve the habitat diversity. The second task is to reduce the pollution from diffuse sources that have negative impacts on surface water and groundwater, such as pesticides, metals, hazardous substances from contaminated sites and others. The third task is to reduce classical pollution from industrial and municipal sources. The last task is to foster water resource utilization in accordance with the environmental target via navigation, energy production, flood protection, special utilization, and other relevant aspects. ${ }^{560}$ The integration of different interests of uses and protection of water resources in the Rhine is reflected explicitly in these tasks. ${ }^{561}$

At the level of the ICPR, the "Programme on the Sustainable Development of the Rhine" ("Rhine 2020") was launched in 2001, which determines the general objectives of Rhine protection policy and measures for implementation. ${ }^{562}$ The core contents of the "Rhine 2020" include habitat conservation, salmon protection, flood mitigation, water quality improvement, and groundwater protection, and requires continuous surveillance of the Rhine. ${ }^{563}$ This Programme also supports the implementation of the WFD and its goal of "good status", and it also improves the implementation of the Flood Management Directive. ${ }^{564}$ This Programme can also reflect the Rhine water regime's function of integration.

\footnotetext{
${ }^{558}$ ICPR, 'River basin management plan 2015' (Official Website of the ICPR) <http://www.iksr.org/en/water-framework-directive/river-basin-management-plan-2015/index.html> accessed 27 October 2016.

${ }^{559}$ ICPR, 'Internationally Coordinated Management Plan 2015 for the International River Basin District of the Rhine' (2015) Bewirtschaftungsplan 2015 IFGE Rhein <http://www.iksr.org/fileadmin/user_upload/Dokumente_en/Brochures/CMP_2015_-_en.pdf> accessed 27 October 2016.

${ }^{560}$ Ibid.

${ }^{561}$ Ibid.

${ }^{562}$ ICPR, 'Rhine 2020 - Program on the sustainable development of the Rhine' (Official Website of the ICPR) <http://www.iksr.org/en/international-cooperation/rhine-2020/index.html> accessed 02 October 2016.

${ }^{563}$ Ibid.

${ }^{564}$ Ibid.
} 
In summary, based on the European WFD, the function of integration is reflected in its aim to achieve a "good status", i.e. good chemical and good ecological status, of the water bodies in the Rhine. The content of the Rhine River Basin Management Plan 2015 and the ICPR's "Rhine 2020" is therefore related to the different uses of water resources in the Rhine. The aim of the integration is to achieve a better status of the ecosystem and the sustainable development of the Rhine. The legal basis for the integration is binding, and the implementation of the integration is fragmented in different directions but they are connected to each other to some extent.

\subsection{Comparison and Analysis}

Compared with the integration in the Rhine water regime, the integration in the Mekong legal water regime has a totally different aim, which is to maintain the balance of the sustainable development of environment and the economic growth. The aim of the integration in the Mekong water regime reflects the urgent necessity to eradicate poverty, which has always been a core problem in the Mekong region. ${ }^{565}$ This stands in contrast to the aim of the integration of the Rhine, i.e. the good chemical and good ecological status of the water bodies. This aim is a more purely environmental aim, and focuses on environmental protection and ecosystem conservation. The difference between the aims of the integration in these two regimes is decided by the development status of the two regions. In the Mekong region, most of the riparian countries are developing countries, and a large number of people in the Mekong region still live in poverty. Therefore, economic growth is a key point for the Mekong water regime, one that cannot be given up. In the Rhine region, most of the countries in the river basin district are developed and are not as concerned about promoting economic growth. Poverty eradication is not an emphasis for the people in the Rhine region; on the contrary, they are more concerned with improving their quality of life and pay more attention on the environment issues.

The function of integration in these two different regimes also uses different approaches. The integration of the Mekong water regime uses regional, transboundary, trans-sectorial, and national approaches to ensure that all activities on water and related resources have been inter-linked. In the Rhine water regime, the

\footnotetext{
${ }^{565}$ Mac Kirby, Chayanis Krittasudthacheewa, Mohammed Mainuddin, Eric Kemp-Benedict, Chris Swartz \& Elnora de la Rosa, 'The Mekong: A Diverse Basin Facing the Tensions of Development' (2010) 35/5 Water International 573, 575.
} 
approaches of integration are based on the "Rhine 2020" and the River Basin Management Plan 2015, which chiefly apply at the regional level and affect the entire Rhine River basin district.

The legal status of activities by the relative Programme and plans for integration in these two regimes is also different. The integration of the Mekong water regime is based on the Mekong Integrated Water Resources Management and the IWRM-based Basin Development Strategy. These two instruments are non-legally binding, but are formulated by the MRC, which is an intergovernmental organization based on the abstract and vague 1995 Mekong Agreement. Therefore, the implementation of these two instruments is also not effective, given that it has only developed a few technical guidelines, supported and facilitated by the MRC's procedures and strategies. ${ }^{566} \mathrm{On}$ the contrary, the integration of the Rhine water regime is based on the River Basin Management Plan 2015 and the Rhine 2020, which were formulated according to the European WFD and the Convention on the Protection of the Rhine. The implementation of the River Basin Plan 2015 and the Rhine 2020 has been successful and effective due to the stable and effective cooperation platform of the European Union, and also the more concrete and detailed contents of the WFD and the Rhine Convention. Thanks to these two instruments, the function of integration in the Rhine has been successful and has already achieved a number of improvements. ${ }^{567}$

\subsubsection{People-related Function}

\subsubsection{Introduction to the ICPR's People-related Function}

The people-related function in the Rhine river basin district can be divided into two components: settlement and leisure. There are more than 58 million people living in the Rhine river basin, and they produce wastewater that is discharged into the Rhine and also need drinking water from the Rhine. ${ }^{568}$ Wastewater originates from

\footnotetext{
${ }^{566}$ MRC, 'Mekong Integrated Water Resources Management Project' (Official Website of the MRC) $<$ http://www.mrcmekong.org/about-mrc/programmes/mekong-integrated-water-resourcesmanagement-project/> accessed 02 October 2016.

${ }^{567}$ ICPR, 'Rhine 2020 - Program on the sustainable development of the Rhine' (Official Website of the ICPR) <http://www.iksr.org/en/international-cooperation/rhine-2020/index.html> accessed 02 October 2016.

${ }^{568}$ Matthias Ruff, Miriam S. Mueller, Martin Loos, Heinz P. Singer, 'Quantitative target and systematic non-target analysis of polar organic micro-pollutants along the river Rhine using high-
} 
households, trade, and industry, and it brings pollutants to the Rhine in the form of chemical substances. Even if there is a municipal wastewater treatment plant to treat the pollutants, some micro-pollutants are still difficult to deal with. This reality also affects the supply of drinking water. ${ }^{569}$ Additionally, the Rhine River watershed plays an important role in people's leisure time. There are numerous recreational and bathing waters in the Rhine, such as Lake Constance and Ijsselmeer, and the Middle Rhine is also a famous site for tourism. Diving, sailing, rowing, fishing, swimming, and other water sports are popular in the Rhine River. In accordance with the demand of people's leisure lives, riverbank path and floodplains preservation has become highly important for local recreation. Protection of the ecosystem in the Rhine and biodiversity conservation has thus also become crucial issues for leisure activities along the Rhine. ${ }^{570}$

Based on the function of promoting people's settlement and leisure along the Rhine, several issues have been taken into account in the Rhine legal water regime, including wastewater treatment, water quality conservation, industrial and agricultural pollution control, flood control, and ecological protection. There are a series of instruments that focus on these issues. Firstly, the Rhine Action Programme (Rhine 2020) addresses the issue of municipal and industrial pollution. ${ }^{571}$ The sediment management plan for the Rhine contributes to reducing the effect of historic pollution on the Rhine ecosystem. ${ }^{572}$ The ICPR has also organized a workshop to draft a strategy for the treatment of micro-pollutants. ${ }^{573}$ To deal with pollution events, the Rhine water regime has also devised an international Warning and Alarm Plan for cooperation on

resolution mass- spectrometry e Identification of unknown sources and compounds' (2015) 87 Water Research 145, 145.

${ }^{569}$ ICPR, 'Settlements' (Official Website of the ICPR)

<http://www.iksr.org/en/uses/settlements/index.html> accessed 02 October 2016.

${ }^{570}$ ICPR, 'Leisure' (Official Website of the ICPR) <http://www.iksr.org/en/uses/leisure/index.html> accessed 02 October 2016.

${ }^{571}$ Plum, Schulte-Wülwer-Leidig (n 539) 98.

${ }^{572}$ ICPR, ‘Sediment Management Plan Rhine Summary’ (2009) ICPR Report No. 175, Problem analysis 〈http://www.iksr.org/fileadmin/user_upload/Dokumente_en/Reports/Bericht_175e.pdf $>$ accessed 29 September 2016.

${ }^{573}$ ICPR, 'Micro-pollutants of diffuse origin (2010)' (Official Website of the ICPR) <http://www.iksr.org/en/events/2nd-icpr-workshop-on-micro-pollutants-of-diffuse-origin/index.html> accessed 02 October 2016. 
cleaning up accidents. ${ }^{574}$ To maintain the water quality and ensure the drinking water supply, the Rhine water regime is making efforts to promote groundwater protection with the Rhine 2020, and also with the WFD's provisions for "good quantitative status" of groundwater. ${ }^{575}$ The Flood Action Plan in the Rhine 2020 and the EU Floods Directive aim to control the risk of floods and reduce related damage. As for ecological protection, both the "Rhine 2020 and the WFD aim to achieve the goal of sustainable development of the ecosystem in the Rhine. There is also a particular directive at the EU level that is specialized for people's leisure lives and is connected to the leisure-promoting function of the Rhine water regime. This directive, called the Bathing Water Directive, was updated in 2006 and aims to protect the water quality for human health. ${ }^{576}$ It has been connected with the WFD and is also a basis for the Rhine water regime's leisure-promoting function. ${ }^{577}$

The Rhine water regime's focus on settlement and leisure opportunities serves a people-related function aimed primarily at achieving a better quality of life for the people and not as much at improving their livelihood. The instruments for this function are mostly legally binding and have consequently been implemented very successfully. Additionally, this function is related to other functions of the Rhine water regime, and therefore most of these instruments are not specialized for promoting people's lives, but rather are fragmented into other functions.

\subsection{Comparison and Analysis}

Compared with the people-related function of the Rhine water regime, this function shows a number of differences to the Mekong water regime on account of the different backgrounds of these two regimes. At first glance, the aims of the people-

\footnotetext{
${ }^{574}$ Mi-Jung Bae, Young-Seuk Park, 'Biological early warning system based on the responses of aquatic organisms to disturbances: A review’ (2014) 466-477 Science of The Total Environment 635, 643.

${ }^{575}$ ICPR, 'Drinking water' (Official Website of the ICPR) <http://www.iksr.org/en/uses/drinkingwater/index.html> accessed 02 October 2016.

${ }^{576}$ Directive 2006/7/EC of the European Parliament and of the Council of 15 February 2006 concerning the management of bathing water quality and repealing Directive 76/160/EEC [2006] OJ L 64/37 (2006), art 1 <http://eur-lex.europa.eu/legal-content/EN/TXT/?uri=CELEX\%3A32006L0007> accessed 28 October 2016.

${ }^{577}$ European Commission, 'Legal Obligations under the EU Bathing Water Directive 2006/7/EC, a summary' (Official Website of the European Commission) <http://ec.europa.eu/environment/water/water-bathing/summary.html> accessed 02 October 2016.
} 
related functions in the two regimes are identical, as they are both geared towards improving people's quality of life. Although their aims are the same, however, the directions of the improvement are totally different. The Mekong water regime's people-related function focuses chiefly on fostering economic growth and alleviating poverty against the background of the reality that a lot of people are still living in poverty. Eradicating this poverty phenomenon is a very crucial step in the development of the Mekong Region. Comparatively, the people-related function in the Rhine water regime focuses on a higher quality of life, which is a higher-level goal than the goal of maintaining stable livelihoods and helping people out of poverty. The reason behind this difference is the different development status of these two regions. Solving the problem of poverty is a crucial topic for the Mekong Region, due to the fact that most of the riparian countries in it are developing countries. In contrast, the poverty problem in the Rhine River district was never a problem in the first place due to the Rhine riparian countries' already having been developed. This also explains why the focus of the Rhine water regime's people-related function is on higher-level improvements like better settlement and leisure opportunities.

In the Mekong water regime, there is no specific instrument for the people-related function; the supportive instruments for this function are documents of the Environmental Programme and the BDP Programme, both of which were formulated by the MRC. Neither of these two instruments is legally binding, and they only provide for a few measures to promote people's environmental awareness and an understanding that people's activities affect the river's quality. Compared to the instruments supporting the people-related function in the Mekong water regime, those in the Rhine water regime are more effective. Despite the fact that some of these instruments are also not legally binding, their implementation has been very successful. The contents of the relevant instruments in the Rhine water regime are also detailed, clear and connected to many other functions of the Rhine, such as pollution control, water quality improvement, ecosystem protection and so forth. On the one hand, the differences between the two regimes' instruments are due to the different demands of the respective riparian countries. On the other hand, the degree of development in the two river basins is distinct, and therefore the relevant problems in these two regimes are distinct as well. For instance, the Rhine water regime's people-related function focuses on pollution control and takes measures to achieve it. 
However, due to the current acceptable status of the water quality of the Mekong River the Mekong water regime seems to care less about the pollution problem. ${ }^{578579}$

\subsubsection{Agriculture}

\subsection{Introduction to the Agricultural Function of the Rhine Water Regime}

Agriculture is a sector that relies on water resources, and therefore the agricultural function in a legal water regime is indispensable. On the one hand, the river water regime should support agricultural development by managing water resources in an appropriate manner and allocating sufficient water to irrigation for agricultural purposes. On the other hand, inappropriate agricultural activities may have negative impacts on the river basin, such as fertilizer polluting the surface water and groundwater; ${ }^{580}$ the river water regime must therefore take measures to prevent these harmful impacts. In the Rhine water regime, the agricultural function mainly focuses on controlling diffuse nutrient and pollutant inputs caused by fertilizers and pesticides. ${ }^{581}$ In 2007, the Ministers in charge of the Rhine demanded further reduction of discharging pollutants and nutrients from all origins, including agriculture, in order to limit dangers to human health and the ecosystem. ${ }^{582}$ There are also some measures being planned that aim to reduce eutrophication of waters from agricultural origins. ${ }^{583}$ Furthermore, there are agricultural water protection measures like riverbank strips, green belt setting in corn and vine culture and ditches to hinder erosion and rain-wash

\footnotetext{
${ }^{578}$ Chea R, Grenouillet G, Lek S (n 474) 14.

${ }^{579}$ MRC, 'FAQ on Procedures for Water Quality' (Official Website of the MRC)

<http://www.mrcmekong.org/about-mrc/mandate/faq-on-procedures-for-water-quality/> accessed 27 October 2016.

${ }^{580}$ O.F. Schoumans a, W.J. Chardon, M.E. Bechmann, C. Gascuel-Odoux, G. Hofman, B. Kronvang, G.H. Rubæk, B. Ulén, J.-M. Dorioz, 'Mitigation options to reduce phosphorus losses from the agricultural sector and improve surface water quality: A review' (2014) 468-469 Science of the Total Environment 1255, 1256.

${ }^{581}$ ICPR, 'Agriculture' (Official Website of the ICPR)

<http://www.iksr.org/en/uses/agriculture/index.html> accessed 02 October 2016.

582 Ibid.

${ }^{583}$ ICPR, 'Nutrients' (Official Website of the ICPR)

<http://www.iksr.org/en/topics/pollution/nutrients/index.html> accessed 02 October 2016.
} 
from intensive farming. ${ }^{584}$ There is also wind protection for reducing the drift of fertilizer and plant protection agents. Finally, the floodplains of brooks and rivers are changed into grassland and nearby water bodies to be changed into grass strips. ${ }^{585}$

The concrete measures of the agricultural function chiefly originate from the Rhine 2020; these actions are aimed at improving water quality and reducing pollution of surface water and groundwater, as well as at habitat patch connectivity and nature protection. ${ }^{586}$ According to the WFD, which aims to achieve a good status of the water bodies and is also relative to the agricultural aspect. ${ }^{587}$ By implementation of the WFD, there are also measures related to agricultural issues that are pollution control, land management, soil erosion, water consumption and irrigation. ${ }^{58}$ There is also research being conducted on cooperation of the WFD with the EU Common Agriculture Policy (CAP), which has an influence on the agricultural function in the Rhine water Regime. ${ }^{589}$ For implementing agricultural measures, a "Guidance for administrations on making WFD agricultural measures clear and transparent at farm level" was formulated at the EU level and aims to support the national and river basin management authorities in making agricultural measures in the Programme of Measures ${ }^{590}$ operational, and specifically to help provide clear and transparent information to farmers. ${ }^{591}$

${ }^{584}$ ICPR, 'Water protection measures' (Official Website of the ICPR)

$<$ http://www.iksr.org/en/uses/agriculture/water-protection-measures/index.html > accessed 02 October 2016.

${ }^{585}$ Ibid.

${ }^{586}$ ICPR, 'Measures' (Official Website of the ICPR) <http://www.iksr.org/en/internationalcooperation/rhine-2020/measures/index.html> accessed 02 October 2016.

${ }^{587}$ WFD (n 524) art 9.

${ }^{588}$ European Commission, 'A review of agricultural measures under the Water Framework Directive' (Official Website of the European Commission) <https://ec.europa.eu/jrc/en/news/review-agriculturalmeasures-under-water-framework-directive-10235> accessed 02 October 2016.

${ }^{589}$ Francesca Somma (ed), 'River Basin Network on Water Framework Directive and Agriculture' (2013) Reference Report by the Joint Research Centre of the European Commission, Executive Summary 〈http://publications.jrc.ec.europa.eu/repository/bitstream/JRC81647/lb-na-25978-en-n.pdf〉 accessed 29 September 2016.

${ }^{590}$ European Commission Guidance for Administrations on Making WFD Agricultural Measures Clear and Transparent at Farm Level [2011] European Commission Directorate-General Environment, Directorate D - Water, Chemicals \& Biotechnology, ENV.D.1-Water, 'River Basin Management Plans 
In summary, the agricultural function of the Rhine water regime focuses on agricultural pollution control, which includes controls on the use of fertilizers and pesticides, and simultaneously also focuses on other measures relevant to soil erosion and water consumption. The instruments for this function of the Rhine water regime are most legally binding (the WFD) and can be implemented at national level with the support of the EU. The agricultural function of the Rhine water regime is not concerned with food security and agricultural future development; rather, this function has set a series of limitations on agriculture to reach the target "good status" of the water bodies in the Rhine.

\subsection{Comparison and Analysis}

The agricultural function of the Mekong water regime has a different aim from that of the Rhine water regime, namely, to ensure food security and support people's livelihoods. Unlike in the Mekong, the agricultural function in the Rhine water regime focuses on pollution control and aims to protect the water bodies in the Rhine river district. With this in mind, the Rhine water regime has established a series of limitations on agriculture in order to achieve the aim of conserving the water quality. Another aspect requiring consideration is that irrigation is an important issue in the Mekong water regime, an aspect that has not been emphasized in the Rhine water regime. The reason for this situation is the different role of the agriculture in these two regions. On the one hand, in the Mekong region, agriculture is to some extent a pillar supporting the economic stability in some riparian countries, such as Vietnam. ${ }^{592}$ On the other hand, a large number of residents in the Mekong rely on agriculture for their livelihood. ${ }^{593}$ Agriculture therefore plays a crucial role in the development of the entire Mekong Region, not only for the water resource management, but also to some extent for regional stability and sustainability. In the Rhine region, however, agriculture is not a cornerstone of regional development. Most of the Rhine riparian

\footnotetext{
(RBMPs) under the WFD, which have had to be prepared by 2009, and their Programmes of Measures (PoM) are a central tool in this process' <http://ec.europa.eu/environment/water/quantity/pdf/guidance_en.pdf> accessed 02 October 2016.

${ }^{591}$ European Commission Guidance for Administrations on Making WFD Agricultural Measures Clear and Transparent at Farm Level (n 590) "Why a guidance on making WFD agricultural measures clear and transparent at farm level?’”.

${ }^{592}$ Mainuddin and Kirby (n 355) 71-72.

${ }^{593}$ Ibid.
} 
countries are developed countries, in which the economic development is based more on industry and other sectors. The environmental demands of the people in the Rhine region are a more urgent problem than their livelihoods, because they already have a high quality of life. The reason for different treatment of irrigation is that the climate is different in the two regions. The Mekong region experiences a tropical monsoon climate in its lower stream, which causes extreme seasonal variation in water availability ${ }^{594}$ This is a crucial element for agricultural arrangement on irrigation. In the Rhine region, the climate's influence on precipitation and water flow quantity is not so extreme, and therefore the Rhine River can offer a stable supply of water for agricultural irrigation.

In the Mekong water regime, there is a specific Programme to carry out the agricultural function, called the Agriculture and Irrigation Programme; this was formulated by the MRC and is a core instrument for this function. It is not a legally binding instrument. The activities of this Programme focus on the building of technical foundations based on cooperation with a series of national agencies in riparian countries, ${ }^{595}$ and have already been met with a fair amount of success. ${ }^{596}$ In the Rhine water regime, there is no specific instrument for the agricultural function, although relative instruments for this function include the WFD and the document of "Rhine 2020" Programme, which are effective and have been implemented very well.

\subsubsection{Flood and Drought}

\subsection{Introduction to the Flood and Drought Function of the Rhine Water Regime} In the Rhine river basin district, extensive floods are always caused by heavy precipitation and water retention, which create a series of damaging effects. Since 1995, the countries bordering the Rhine have worked on reducing damage caused by

\footnotetext{
${ }^{594}$ Browder and Ortolano (n 12) 501.

${ }^{595}$ Mekong River Commission Agricultural and Irrigation Programme 2011(AIP), 38-39. <http://www.mrcmekong.org/assets/Publications/Programme-Documents/AIP-Pogramme-Doc-V4Final-Nov11.pdf> accessed 02 October 2016.

${ }^{596}$ MRC, ‘Agriculture \& Irrigation’ (Official Website of the MRC) <http://www.mrcmekong.org/about-mrc/programmes/agriculture-and-irrigation-programme/> accessed 02 October 2016.
} 
floods, ${ }^{597}$ and the ICPR created the Action Plan on the Floods in 1998 to support related flood prevention and protection efforts. ${ }^{598}$ As an important action of the "Rhine 2020" Programme, the Action Plan on Floods has four objectives for achieving the goal by the year 2020. The first objective is to reduce the damage risks by 25 percent. The second is to reduce the effect of floods downstream. The third objective is to improve the risk awareness of the population living in the immediate vicinity of the Rhine or near the Rhine. Fourthly, the plan recognizes that additional efforts must be made to accurately improve flood forecasting. ${ }^{59}$ The ICPR created the Rhine Atlas 2015 to draw people's attention to their personal risk and possible damage to property by extreme floods. ${ }^{600}$ The Rhine Atlas supports the implementation of flood prevention measures and also the Floods Directive that reduce flood hazards and flood risk for the main stream of the Rhine. ${ }^{601}$

The EU Floods Directive aims to reduce and manage the adverse impacts of floods "on human health, the environment, cultural heritage and economic activities". ${ }^{602}$ Furthermore, this directive is also concerned with public participation and coordination with the WFD. ${ }^{603}$ On October 18, 2007, the conference of the Rhine Ministers confirmed the targets of flood prevention and protection and charged the ICPR with supporting the implementation of the Floods Directive in the international river basin district Rhine, parallel to the implementation of the WFD. ${ }^{604}$ The Action

\footnotetext{
${ }^{597}$ ICPR, 'Floods' (Official Website of the ICPR) <http://www.iksr.org/en/topics/floods/index.html> accessed 02 October 2016.

${ }^{598}$ ICPR, ‘Action Plan on Floods' (Official Website of the ICPR)

<http://www.iksr.org/en/international-cooperation/rhine-2020/action-plan-on-floods/index.html> accessed 02 October 2016.

${ }^{599}$ Markus Disse and Heinz Engel, 'Flood Events in the Rhine Basin: Genesis, Influences and Mitigation' (2001) 23 Natural Hazards 271, 287.

${ }^{600}$ ICPR, 'Floods' (Official Website of the ICPR) <http://www.iksr.org/en/topics/floods/index.html> accessed 02 October 2016.

${ }^{601}$ ICPR, 'Rhine Atlas 2015' (Official Website of the ICPR)

<http://www.iksr.org/en/documentsarchive/rhine-atlas/index.html> accessed 02 October 2016.

${ }^{602}$ Floods Directive (n 533) art 1.

${ }^{603}$ ICPR, 'Directive on the Assessment and Management of Flood Risks', (Official Website of the ICPR) <http://www.iksr.org/en/floods-directive/index.html> accessed 02 October 2016.

${ }^{604}$ ICPR, 'Flood', (Official Website of the ICPR) < http://www.iksr.org/en/topics/floods/index.html> accessed 02 October 2016.
} 
Plan on Floods served as a model when drafting the Floods Directive treating similar issues. $^{605}$

In continuation of the Action Plan on Floods, the Flood Risk Management Plan was drafted on 22 December 2015 for the international river basin district of the Rhine catchment, with its several member states that sometimes extend beyond the EU's borders. ${ }^{606}$ This Plan is also a part of the implementation of the European Floods Directive, which concerns the period from 2015-2021 and contains joint targets and measures of states for different aspects of flood prevention and technical flood protection. Additionally, the Plan contains important information of flood risks and links to the national flood risk management plans of the states in the Rhine catchment. The states are obligated to review and update this Plan every 6 years based on specific requirements. ${ }^{607}$

The instruments above are concerned with several flood-related issues, such as flood prevention and protection, public awareness improvement and water retention alleviation. Additionally, there are also flood announcement centers in the Rhine watershed that can provide warning and forecasting information. ${ }^{608}$ These centers have been established in states bordering on the Rhine on a relative legal basis. Contact between different centers is based on bilateral scale and specific requirements. Some information is exchanged between centers via contracts or letters, and other information in more informal ways. ${ }^{609}$

The WFD is primarily concerned with drought prevention, groundwater protection and climate change. ${ }^{610}$ In the Rhine water regime, drought is related to low water levels in the Rhine River, which affects navigation, hydropower production and

\footnotetext{
${ }^{605}$ ICPR, 'Directive on the Assessment and Management of Flood Risks' (Official Website of the ICPR) <http://www.iksr.org/en/floods-directive/index.html> accessed 02 October 2016.

${ }^{606}$ ICPR, 'Flood Risk Management Plan 2015' (Official Website of the ICPR)

<http://www.iksr.org/en/floods-directive/flood-risk-management-plan/index.html> accessed 02

October 2016.

${ }^{607}$ Ibid.

${ }^{608}$ ICPR, 'Flood warning and forecasting centres' (Official Website of the ICPR)

$<$ http://www.iksr.org/en/topics/floods/flood-warning-and-forecasting-centres/index.html> accessed 02

October 2016.

${ }^{609} \mathrm{Ibid}$

${ }^{610}$ WFD (n 524) art 1, 4, 12.
} 
ecosystem development. ${ }^{611}$ There is also a relevant report offering suggestions for how to solve the problem of low water in the Rhine catchment, with a specific focus on water-related technical improvement. ${ }^{612}$

In summary, the flood and drought prevention function of the Rhine water regime focuses chiefly on flood management. Flooding in the Rhine water regime generally has an adverse impact on the population, ecosystem and regional economy. The measures of this function focus on flood prevention and protection from relative damage. The instruments for this function are very effective and have been implemented very successfully. ${ }^{613}$ The collection of related data and information by the flood warning and forecasting centers is not systematic; rather, it is based on bilateral scale and informal methods.

\subsection{Comparison and analysis}

In accordance with the different impacts floods have on the respective regions, the management of floods in the Mekong versus the Rhine water regime is different as well. As opposed to in the Rhine river basin, the floods in the Mekong River basin are caused not only by abnormal precipitation, but also by the local climate. Flooding in the Mekong River basin is a stable phenomenon (unlike in the Rhine river basin, where it primarily has an adverse impact) that brings a series of benefits to the river basin, such as sustaining fisheries, supplying water for the dry season, recharging the groundwater and fertilizing the soil for agriculture. ${ }^{614}$ Furthermore, the degree of impact from the floods in the Mekong river basin is more severe than in the Rhine river basin due to the association between the river and the regional agriculture and fisheries. Because these two sectors play vital roles in the Mekong regional economy and people's livelihoods, the related functions for floods management in these two regimes also have different aims. In the Rhine water regime, the flood function chiefly focuses on prevention and protection from damage, whereas the same function

\footnotetext{
${ }^{611}$ ICPR, 'Low Water' (Official Website of the ICPR) < http://www.iksr.org/en/topics/lowwater/index.html> accessed 02 October 2016.

${ }^{612}$ ICPR, 'Niedrigwasserperioden 2011 im Rheineinzugsgebiet' (2012) ICPR Bericht Nr. 198, 18 <http://www.iksr.org/uploads/media/198_d_01.pdf> accessed 29 September 2016.

${ }^{613}$ ICPR, ‘Action Plan on Floods' (Official Website of the ICPR)

<http://www.iksr.org/en/international-cooperation/rhine-2020/action-plan-on-floods/index.html> accessed 02 October 2016.

${ }^{614}$ Hoa, Nhan, Wolanski, Cong and Shigeko (n 381) 116.
} 
of the Mekong water regime concentrates more on the management of floods based on their regularity, certainty and the benefits they can bring to the Mekong River basin.

Another aspect that must be compared is the flood data information collection and exchange. In the Mekong water regime, the flood data information collection and exchange has been ultimately complemented by the MRC at an institutional level that collects data on a basin-wide scale from numerous monitoring stations along the mainstream and tributaries. ${ }^{615}$ But in the Rhine water regime, the flood data information has been collected at the national level, and the exchange of data information is based on bilateral scale, such as contracts, but also other informal methods, such as letters. Hence, we can say that the data and information collection and exchange in the Mekong water regime is more systematic and developed.

The attitudes towards drought in these two regimes are also quite different. The drought problem in the Mekong is always connected with agricultural production on the one hand, which affects people's livelihoods and food security in the Mekong region, and navigation on the other hand. In the Rhine water regime, drought is connected with groundwater, navigation, and climate change, and has not been treated as a serious issue as in the Mekong region. This situation also stems from the different degree of impact droughts cause on these two regions.

The instruments for the function of floods and drought in these two regimes also have different characteristics. In the Mekong water regime, there are two Programmes that support this function: the Flood Management and Mitigation Programme and the Information and Knowledge Management Programme. These two Programmes' documents are not legally binding and more like policies formulated by the MRC. The activities of these two Programmes are chiefly on data and information collection, and monitoring and forecasting systems. In comparison with these, the instruments related to floods in the Rhine water regime, which are based on the legally binding Flood Directive and the WFD, are more effective. The implementation of these instruments in the Rhine water regime has also been more successful and has improved several aspects of the Rhine River basin.

\footnotetext{
${ }^{615}$ MRC, 'River Monitoring' (Official Website of the MRC) < http://www.mrcmekong.org/mrc/rivermonitoring/> accessed 28 October 2016.
} 


\subsubsection{Climate Change}

3.2.2.5.1. Introduction to the Climate Change Function of the Rhine Water Regime Climate change and its effects on a series of environmental aspects are now in focus all over the world. In the Rhine River basin district, climate change is also an important element for regional development. Firstly, the periods with floods or low water are more frequent and more distinct, which causes more frequent and greater damage and also affects navigation and the water supply. ${ }^{616}$ Furthermore, low water slows down the rate at which groundwater recharges and affects its quality. ${ }^{617}$ The higher temperatures associated with climate change also raise the water temperature, which in turn affects the ecological and chemical status of water bodies ${ }^{618}$ Because of these impacts, efforts have been made to improve the assessment of the degree of impact on the discharge regime of the Rhine, and in 2007 the ICPR drafted a "Study of Scenarios for the Discharge Regime of the Rhine". ${ }^{619}$

In 2013, based on the assessment from existing studies on the discharge regime and on the water temperature, the Conferences of the Rhine Ministers charged the ICPR with formulating a provisional strategy to adapt climate change in the Rhine catchment. This strategy should include sustainable precautionary concepts for water management, as well as measures aimed at adapting to the effects of climate change. ${ }^{620}$ The ICPR also formulated a Climate Change Adaptation Strategy, which is a living document that contains several measures for climate change adaptation, for the international river basin district of Rhine in $2015 .{ }^{621}$ It contains several principles for the adaptation measures, and also dictates measures that can be used to deal with

\footnotetext{
${ }^{616}$ H. Middelkoop, K. Daamen, D. Gellens, 'Impact of Climate Change on Hydrological Regimes and Water Resources Management in the Rhine Basin’ (2001) 49/1 Climatic Change 105, 105-106. 
different aspects of climate change. ${ }^{622}$ Firstly, for the aspect of water quantity, this strategy focuses on flood risk management and low water management. ${ }^{623}$ For the aspect of water quality, this strategy emphasizes pollution control, which has been connected with industrial and municipal pollutants and a reduction in nutrients, diffuse origin reduction, sediments protection, warning and alarm systems, monitoring of pollutants, and thermal discharge control. ${ }^{624}$ As for ecosystem protection, this strategy mentions habitat renaturing and protection, habitat network connectivity, ecological flood protection, and so forth. There are also measures for other aspects, such as drinking water supply, energy production, fisheries, navigation and so on. ${ }^{625}$

In summary, the function of adapting climate change in the Rhine water regime has several different foci based on a strategy that was formulated by the ICPR. Although this key strategy is not legally binding, its implementation under the Rhine water regime can be effective thanks to other related instruments, namely the "Rhine 2020" and the EU legislation. ${ }^{626}$

\subsection{Comparison and Analysis}

There are some common challenges and issues related with the climate change function of these two regimes, such as "saline intrusion, flooding and inundation, low flows and droughts, biodiversity, navigation, sedimentation and (delta) morphology, increased variation of climate, temperature increase, impacts of climate change, land subsidence, unequal distribution of water resources in time and space, groundwater management (protection, sustainability, quality and quantity), management in the future of water production and water quality due to rising living standards." ${ }^{27}$ There are, however, also aspects that differ in the two regimes; these include "natural factors, institutional frameworks and cooperation history, monitoring and data, financial

\footnotetext{
${ }^{622}$ ICPR (n 620) 17-18.

${ }^{623}$ ICPR (n 620) 18-20.

${ }^{624}$ ICPR (n 620) 20-21.

${ }^{625}$ ICPR (n 620) 23.

${ }^{626}$ Barbara Hall and Sopheak Meas (ed), 'First Rhine-Mekong Symposium: Climate Change and its Influence on Water and Related Sectors' (2014) Mekong River Commission Symposium report, 4 $<$ http://www.mrcmekong.org/assets/Publications/Reports/First-Rhine-Mekong-symposium-report.pdf> accessed 29 September 2016.

${ }^{627}$ Ibid.
} 
support and mechanisms; development level and stage that influence priority setting, low water and water quality, and approaches to flooding." ${ }^{\prime 28}$

The instruments for the function of climate change in these two regimes have similar approaches, but the starting points for these instruments are different; that is, the degree of development on the climate change issue is different. In the Rhine water regime, substantial basin-wide research has been conducted, but in the Mekong water regime, this research has just begun. ${ }^{629}$ Furthermore, the strategic focus of these two instruments is also different. The Rhine water regime is concerned about water temperature, a factor that has not been mentioned by the Mekong water regime. ${ }^{630}$ The Climate Change Adaptation Initiative, formulated by the MRC under the Mekong Basin Development Strategy, is not legally binding. The Climate Change Adaptation Strategy for the IRBD Rhine in the Rhine water regime is based on two umbrella conventions: the document of the "Rhine 2020" Programme and the EU legislation containing the WFD and Floods Directive. ${ }^{631}$ This basis is more effective, guaranteeing the implementation of the function on climate change within the Rhine River basin.

\subsubsection{Navigation}

\subsection{Introduction to the Navigation Function of the Rhine Water Regime}

The Rhine River is one of the most important shipping lanes in Europe and, for that matter, the entire world, and the importance of navigation of the Rhine River will continue to increase. ${ }^{632}$ However, even though the inland navigation is more environmentally friendly compared to other transportation means, it still causes deterioration of the ecosystem and the water quality of the Rhine River. ${ }^{633}$ In 2007, the ICPR established cooperation with the Central Commission for Navigation on the Rhine; in the same stroke, it began to "inform inland navigation of risks of deliberate

\footnotetext{
${ }^{628}$ Ibid.

${ }^{629}$ Ibid

${ }^{630}$ Ibid

${ }^{631}$ Ibid.

${ }^{632}$ ICPR, 'Navigation' (Official Website of the ICPR)

<http://www.iksr.org/en/uses/navigation/index.html> accessed 02 October 2016.

${ }^{633}$ Vytautas Paulauskas, 'Navigational risk assessment of ships' (2006) 21/1 Transport 12, 14.
} 
or accidental losses of pollutants that continue to be recorded". ${ }^{634}$ Additionally, inland navigation brings other effects such as those from waves on the riverbank biocenosis, whirls from ships' propellers cloud the water and affect the sediments, and effects on the spreading of animal and plant species. ${ }^{635}$

The Central Commission for the Navigation on the Rhine (CCNR) is one of the oldest international organizations in the world and was established based on the Revised Convention for Navigation on the Rhine with reference to the Mannheim Document on 17 October $1868 .{ }^{636} \mathrm{It}$ is an administrative institution that addresses issues of inland navigation on the Rhine and fosters international cooperation with other institutions, such as the ICPR. ${ }^{637}$ The current missions of the CCNR are to administrate the Rhine system of regulation and to promote inland navigation as well as facilitate integration in the European transport system. ${ }^{638}$

In summary, there is no other specific instrument dealing with the navigational function of the Rhine water regime. The navigational function is instead dealt with via the cooperation between the ICPR and the CCNR, which focuses on transport pollutant control, water quality conservation and ecosystem protection. Cooperation therefore takes place under two legal frameworks of the Rhine Convention and the Mannheim Document, and these legal instruments can ensure the implementation of the Rhine regime's navigational function.

\subsection{Comparison and Analysis}

The navigational function in the Mekong water regime shows several differences when compared with the navigational function in the Rhine water regime. In the Mekong water regime, the MRC created a Navigation Programme as a tool specifically geared towards the navigational function that focuses on effective and efficient transboundary trade as well as transportation safety. The navigational

\footnotetext{
${ }^{634}$ ICPR, 'Navigation' (Official Website of the ICPR)

<http://www.iksr.org/en/uses/navigation/index.html> accessed 02 October 2016.

635 Ibid.

${ }^{636}$ CCNR, 'Organisation' (Official Website of the CCNR) <http://www.ccr-zkr.org/11000000-en.html> accessed 02 October 2016.

${ }^{637}$ Ibid.

${ }^{638}$ CCNR, 'Current missions of the CCNR' (Official Website of the CCNR) <http://www.ccrzkr.org/11010400-en.html> accessed 02 October 2016.
} 
function in the Rhine water regime, in contrast, focuses on shipping pollution control and water quality conservation.

The reason for this difference has to do with the specific background of the respective regime. The Mekong region is now in a developing status, therefore economic growth plays a crucial role in this region. Furthermore, the MRC is the only regional institution that deals with issues regarding Mekong River management and its sustainable development. The MRC must hence try its best to fulfill this role and foster regional economic development as well as alleviate the poverty problem. Therefore, the navigational function in the Mekong water regime has also been affected and focuses on facilitating trans-boundary trade and transportation safety. In the Rhine River basin, the economic development of the region is currently not an urgent goal to achieve; conversely, environmental protection is becoming increasingly important for people's lives. The navigational function in the Rhine water regime hence focuses on the environmental aspects of navigation. In addition to this, there is another institution, the CCNR, that already provides comprehensive management of navigation on the Rhine. Therefore, the Rhine water regime can concentrate the activities related to its navigational function on the environmental impacts of inland navigation.

Comparing the instruments for this function in these two regimes, the instruments in the Mekong water regime are more fragmentary. The Mekong Agreement is the framework legal basis for this function, and the document of Navigation Programme is mainly for increasing trade opportunity and ensuring efficient and safe river transportation. There is also a bilateral agreement between the Cambodia and the Vietnam for the reducing trans-boundary navigation restricts and improving navigation safety. On the contrary, in the Rhine water regime the navigational function is only based on the cooperation between the ICPR and CCNR, which is focuses on pollution control and water quality conservation. Therefore, except the two conventions for the two organizations, the document of the "Rhine 2020" Programme, the European WFD and the European Flood Directive in the Rhine water regime are related to the focus of this cooperation and can be the legal basis for its implementation. 


\subsubsection{Nature and Ecology}

\subsubsection{Introduction of this Function by the Rhine water regime}

Due to its water resources, the Rhine watershed is an important basis for the local ecosystem. The Rhine River basin needs to be protected against pollution from agricultural, industrial and urban sources. ${ }^{639}$ Additionally, there are numerous protection areas for birds and freshwater fish in the Rhine watershed; these areas are crucial for the sustainability of these fish and birds' habitats, as well as for biodiversity development in the Rhine river basin district. ${ }^{640}$ Hence, protection of the Rhine River also affects the conservation and restoration of the ecological balance in the Rhine. At the EU level, there are several instruments related to ecological conservation in the Rhine river basin district, such as the Habitat Directive, the EC Freshwater Fish Directive, and the Shellfish Waters Directive. In the Rhine water regime, the instruments promoting the function of nature and ecology protection are documents of the "Rhine 2020" Programme, the "Salmon 2020" Programme, the Programme on Migratory Fish, as well as others; among them, the "Rhine 2020" Programme plays the main role in fulfilling this function. ${ }^{641}$

One objective of the "Rhine 2020" Programme is to "restore the former network of habitats typical for the Rhine (habitat patch connectivity) as well as ecological river patency of the Rhine from Lake Constance to the North Sea and the patency of Rhine tributaries included in the program on migratory fish." ${ }^{642}$ The "Rhine 2020" Programme lists several measures, including the preservation of freely flowing river sections, the restoration of river dynamics, the establishment of a more varied design of the structure of river banks and beds, the opening of old alluvial areas to the river,

\footnotetext{
${ }^{639}$ Rob S. E. W. Leuven, Gerard van der Velde, Iris Baijens, Janneke Snijders, Christien van der Zwart, H. J. Rob Lenders, Abraham bij de Vaate, 'The river Rhine: a global highway for dispersal of aquatic invasive species’'(2009) 11 Biological Invasions 1989, 1990.

${ }^{640}$ ICPR, 'Nature protection' (Official Website of the ICPR) $<$ http://www.iksr.org/en/uses/natureprotection/index.html> accessed 02 October 2016.

${ }^{641}$ Ibid.

${ }^{642}$ ICPR, 'Measures aimed at improving the Rhine ecosystem' (Official Website of the ICPR) $<$ http://www.iksr.org/en/uses/nature-protection/measures-aimed-at-improving-the-rhineecosystem/index.html> accessed 02 October 2016.
} 
the removal of obstacles to the migration of the river fauna, and the reconnection of old river branches and torrents. ${ }^{643}$

To summarize the function relating to nature and ecology in the Rhine water regime: this function is fulfilled by several instruments that cover different aspects of nature and ecology protection. These instruments focus on habitat conservation and biodiversity improvement. The "Rhine 2020" Programme acts as a primary tool for this function, and in this sense also reflects the core content of the Rhine water regime, which is to maintain the "good status" of the water bodies in the Rhine river basin district. There are also other relevant instruments from the EU level, which include the Habitat Directive, the EC Freshwater Fish Directive, and the Shellfish Waters Directive. Furthermore, the EU WFD and Flood Directive are also related to this function due to their vital role in the Rhine water regime's legal foundation.

\subsection{Comparison and Analysis}

In the Mekong water regime, the function of nature and ecology protection is called “environmental health" based on the MRC's activities of Basin Development Plan Programme, the Fisheries Programme and the Environmental Programme and so on. These instruments address the issues of biodiversity and balance between economic, environmental, and social development in the Mekong River basin. This function of the Mekong water regime not only aims to protect the environment, but also helps people adapt to environmental uncertainties in a more prepared manner. ${ }^{644}$ In contrast, in the Rhine water regime, the function of nature and ecology focuses more on environmental aspects, such as habitat conservation, biodiversity protection, and water quality control, and does not mention issues relevant to riparian population and economic development.

There is no specific instrument for this function in either of these two regimes; rather, this function is fulfilled by basin-wide Programmes or plans, such as the "Rhine 2020" Progrmme and the Mekong BDP Programme. Even though there are also some other relevant tools, none of them are comprehensive and they generally only focus on one particular aspect, such as the Fisheries Programme in the Mekong water regime and the ICPR's "Salmon 2020" Programme and their primary focus on biodiversity

\footnotetext{
${ }^{643}$ Ibid.

${ }^{644}$ MRC, 'Environmental Health' (Official Website of the MRC)

<http://www.mrcmekong.org/topics/environmental-health/> accessed 02 October 2016.
} 
protection. The function of nature and ecology protection in both of these regimes is therefore not isolated, but rather connected with the other functions of these two regimes. One example of this is that, in the Mekong water regime, the function of nature and ecology protection has been connected with economic growth and social development, and meanwhile functions of climate change, flood and drought management are also related to this function. ${ }^{645}$ In the Rhine water regime, the function of nature and ecology protection has also been connected to the function of water quality, agriculture, flood control and so forth. Furthermore, some instruments for this function in the Rhine water regime come from the EU level, which are legally binding, such as the Habitat Directive, the EC Freshwater Fish Directive, the Shellfish Waters Directive, as well as the EU WFD and the Flood Directive, which also stipulate the goal of ecosystem protection. Therefore, the function of nature and ecology protection in the Rhine is more effective and its implementation can be better ensured. In the Mekong water regime, there is no other instrument outside the framework of the MRC, and the instruments under the MRC are more like regional policies that are not legally binding, which affect this function's implementation.

In summary, the focuses of the function of nature and ecology protection in these two regimes are very similar in that it is connected with other functions of the regime. In the Rhine water regime, this function is more purely environmental, and in the Mekong this function is not only for environmental protection, but also for the balance between environmental, social and economic development. Additionally, measures to deal with the impacts of ecological uncertainty on people's lives have also been devised by the Mekong water regime. Most of the instruments dealing with this function in these two regimes are not legally binding; however, in the Rhine water regime, some instruments are from the EU level, making them more effective and efficient than comparable instruments in the Mekong water regime.

\subsubsection{Hydropower}

\subsection{Introduction of this Function by the Rhine Water Regime}

Although hydropower is a form of clean energy that generally will not cause pollution nor consume water resources, it still has a series of negative impacts on the ecological functions and sustainable development of rivers. The establishment of many

\footnotetext{
${ }^{645}$ Ibid.
} 
reservoirs and barrages restricts fish migration and also cause many fish to be injured or die in the turbines. The development of hydropower also causes an increase in backwaters and habitat loss and damages the natural development of water bodies. Additionally, hydropower development also entails streambed erosion and causes the groundwater to sink. Finally, these negative impacts also affect alluvial plains, drinking water supply, and agriculture. ${ }^{646}$

Hydropeaking, a periodic change of water bodies characterized by the short-term change from high water to very low water, is a major cause of these negative impacts. This unnatural change of water bodies causes considerable detriment, such as "reducing the stock of fish and macrozoobenthos species, reducing biomass of fish and macrozoobenthos, altering the species composition of macrozoobenthos and fish, increasing drift and running aground of water organisms (among others juvenile fish), largely causing a biological desertation of the zone of changing water levels". ${ }^{647}$ The ICPR therefore requires the implementation of measures to mitigate hydropeaking, such as by slowing down the water discharge. ${ }^{648}$

The Rhine water regime has its own relevant instruments to deal with these negative impacts. Firstly, to promote sustainable development of the Rhine river basin, the Rhine Convention requires thorough ecological consideration when developing hydropower. ${ }^{649}$ The "Rhine 2020" Programme is also concerned with the impacts of hydropower, and has consequently devised related measures aimed at improving the Rhine ecosystem. As a legal basis of the Rhine water regime, the EU WFD has also recognized the impacts of hydropower and includes this issue in its efforts to harmonize water use and environmental targets. ${ }^{650}$

\footnotetext{
${ }^{646}$ ICPR, 'Hydropower' (Official Website of the ICPR)

<http://www.iksr.org/en/uses/hydropower/index.html> accessed 02 October 2016.

${ }^{647}$ ICPR, 'Hydropeaking' (Official Website of the ICPR)

<http://www.iksr.org/en/uses/hydropower/hydropeaking/index.html> accessed 02 October 2016.

${ }^{648}$ Ibid.

${ }^{649}$ ICPR, 'The Rhine in the triangle of sustainability' (Official Website of the ICPR)

<http://www.iksr.org/en/international-cooperation/legal-basis/convention/sustainability/index.html> accessed 02 October 2016.

${ }^{650}$ ICPR, 'Planning of measures' (Official Website of the ICPR) $<$ http://www.iksr.org/en/internationalcooperation/legal-basis/european-water-framework-directive/planning-of-measures/index.html > accessed 02 October 2016.
} 
There is also a specific inter-governmental organization for joint hydrological measures of sustainable development in the Rhine basin, called the International Commission for the Hydrology of the Rhine Basin (CHR). Its main mission is to supply knowledge of the hydrology in the Rhine river basin, and to offer solutions for cross-border problems. ${ }^{651}$ Therefore, its achievements can be useful for the Rhine water regime's function of hydropower. But there is no direct cooperation between the ICPR and the CHR.

To summarize the hydropower function of the Rhine water regime, we can state that its core objective is to mitigate the negative impacts from hydropower development and conserve the ecosystem in the Rhine river basin. Despite this, there is no specific instrument to fulfill this function in the Rhine water regime. Relevant measures are dictated by general instruments, such as the EU WFD, the Rhine Convention, and the document of the "Rhine 2020" Programme, and these measures chiefly focus on ecological protection and limiting hydropower development. The specific organization for the hydrology measures, the CHR, is not a governance organization and can only offer some scientific information for this issue.

\subsection{Comparison and Analysis}

Several differences can be observed when comparing the function dealing with hydropower of the Mekong water regime versus the Rhine water regime. Firstly, there is no specific instrument for hydropower development in the Rhine water regime; the Mekong water regime, on the other hand, boasts the Initiative on Sustainable Hydropower (ISH). The ISH cooperates with activities of other Programmes of the Mekong water regime, such as the BDP Programme, the Fisheries Programme, the Environment Programme, and also the Navigation Programme, which focuses on "advancing regional cooperation for the sustainable management of hydropower projects from a river basin management perspective". The measures taken aim to absorb international experiences, develop regional technical knowledge, and share practices to all stages of planning.

Another aspect that needs to be mentioned is the varying focus of the hydropower function in these two regimes. In the Mekong water regime, the function of

\footnotetext{
${ }^{651}$ CHR, 'General' (Official Website of the CHR) < http://www.chr-khr.org/en/general > accessed 02 October 2016.
} 
hydropower focuses on fostering the sustainable development of hydropower, thereby boosting national economic growth and reducing poverty. Although this function is already dealing with the negative impacts of hydropower development and dictates that these impacts continue to be considered and mitigated, this is only happening on a minor level. In contrast, the primary focus of the hydropower function in the Rhine water regime is on mitigating the negative impacts of hydropower development, and a series of limiting measures have already been adopted to some aspects of the hydropower development.

The reason for the differences just mentioned is the different role of hydropower in these two regions. Hydropower has massive potential in the Mekong river basin, yet only 10 percent of this potential has been exploited. If exploited to the greatest extent possible, it stands to boost national economic growth, improve the livelihood of local people, and alleviate the poverty problem. Therefore, the exploitation of hydropower plays a decisive role in regional development, particularly for developing regions like those in the Mekong River basin. In the Rhine River basin, in contrast, the potential of hydropower is not as considerable as in the Mekong River basin, nor does the regional economic development rely as heavily on the exploitation of hydropower. Additionally, in accordance with the Rhine water regime's primary target of achieving a "good status" of the water bodies in the Rhine river basin, the hydropower function mainly focuses on ecological protection and limiting hydropower development.

A comparison of the instruments geared towards fulfilling the hydropower function of these two regimes makes it clear that their implementation in the Rhine water regime has been more effective due to the fact that the basis of hydropower measures are generally all legally binding, such as those imposed by the Rhine Convention and the EU WFD. In the Mekong, on the other hand, the hydropower function of the MRC is based on the ISH and the cooperation between the ISH and the work of other Programmes, neither of which are legally binding and therefore relatively ineffective. Finally, most of the hydropower projects in the Mekong River basin have been supported by donors; because the donors have a say in how the hydropower projects 
are carried out, this reduces the independence and, consequently, the effectiveness of the MRC's hydropower function. ${ }^{652}$

\subsubsection{Water Quality}

\subsection{Introduction of this Function by the Rhine water regime}

In the Rhine River basin, maintaining water quality has been an important task ever since widespread pollution began in the era of the industrial development. ${ }^{653}$ The water quality is directly related to the supply of drinking water available to riparian inhabitants, and also plays a vital role in the ecosystem of the Rhine River basin. ${ }^{654}$ During the last 30 years, the water quality has been improved considerably thanks to the Rhine water regime and especially to the ICPR's efforts. ${ }^{655}$ Despite this improvement, however, there are still several substances in the water of the Rhine that must be dealt with. In the future, therefore, water quality should be still a crucial topic in the Rhine water regime based on its goal of sustainable development. Future efforts to improve water quality must focus on reduction of micro-pollutants from urban settlement, reduction of diffuse inputs of pollutants and nutrients from agricultural and industrial origins, and also the protection of river sediments. ${ }^{656}$

Water quality improvement basically consists of two components: surface water quality and groundwater quality. Surface water quality improvement is chiefly dictated by the WFD and the ICPR's "Rhine 2020" Programme, which aim to reduce pollutants from agricultural and industrial origins and to achieve the goal of the "good ecological and chemical status" of the Rhine's water bodies. ${ }^{657}$ Groundwater quality improvement, on the other hand, is mainly based on the WFD and focuses primarily on pollution reduction. ${ }^{658}$ There are several monitoring stations in the Rhine river

\footnotetext{
${ }^{652}$ Hirsch, Jensen with Boer, Stephen, Gerald, Lyster (n 251) 81-82.

${ }^{653}$ Plum, Schulte-Wülwer-Leidig (n 539) 95.

${ }^{654}$ Ibid.

655 Ibid.

${ }^{656}$ ICPR, 'Water Quality' (Official Website of the ICPR) < http://www.iksr.org/en/topics/waterquality/index.html> accessed 2 October 2016.

${ }^{657}$ ICPR, 'Surface waters' (Official Website of the ICPR) <http://www.iksr.org/en/topics/waterquality/surface-waters/index.html> accessed 2 October 2016.

${ }^{658}$ ICPR, 'Groundwater' (Official Website of the ICPR) < http://www.iksr.org/en/topics/waterquality/groundwater/index.html> accessed 2 October 2016.
} 
basin belonging to different riparian countries that provide relevant information on water quality. ${ }^{659}$ Additionally, according to the Warning and Alarming Plan of the ICPR, the negative impacts from accidents in the Rhine River can be also mitigated as a result. ${ }^{660}$ Furthermore, to improve the water quality of the Rhine water bodies, the Rhine water regime has also begun cooperating with marine protection regimes, such as the cooperation between the ICPR and the OSPAR Convention (The Convention for the Protection of the Marine Environment of the North-East Atlantic) on the protection of the aaaaNortheast Atlantic. ${ }^{661}$

The water quality function of the Rhine water regime is based on several instruments, such as the WFD, document of the "Rhine 2020" Programme and the OSPAR Convention, which are mainly legally binding or important part of a legal framework. The focus of this function in the Rhine water regime is to reduce pollution from agricultural, industrial, and municipal origins. The implementation of this function has been showed to be effective and efficient.

\subsection{Comparison and Analysis}

The water quality function of the Mekong water regime has adopted several measures aimed at improving water quality for sustainable development, as well as dictating how to deal with emergencies and accidents and how to enhance the public's awareness of water quality issues and foster public participation in water quality improvement efforts. Compared with the Rhine water regime, however, this function is only a framework and very abstract in the Mekong water regime, and hence cannot be implemented very well. Because the opposite is the case in the Rhine water regime, the water quality has been improved both effectively and efficiently in recent years.

The reason for this difference originates from the different developmental histories of these two river basins. The Rhine River basin experienced an industrial development era that discharged a large amount of wastewater into the Rhine River, which entailed serious pollution and many accidents that negatively affected the Rhine River basin. It

\footnotetext{
${ }^{659}$ ICPR, 'Monitoring of the state' (Official Website of the ICPR) $<$ http://www.iksr.org/en/topics/water-quality/monitoring-of-the-state/index.html> accessed 2 October 2016.

${ }^{660}$ Ibid.

${ }^{661}$ ICPR, 'Targets aimed at improving water quality' (Official Website of the ICPR)

<http://www.iksr.org/en/topics/water-quality/targets/index.html> accessed 2 October 2016.
} 
took a long time to improve the water quality and to restore the Rhine River's ecological status, and the efforts necessary to do this also cost a lot of money. This historical lesson made the Rhine water regime emphasize the issue of water quality, and meanwhile be concerned about the ecosystem and pollution reduction. In contrast, the Mekong River basin is now a developing region, and the industry in this region is not so developed. Furthermore, municipal development is also "backwards", and the means of agriculture in this region are chiefly natural. Additionally, the climate in the Mekong River basin brings regular floods that will also recharge the groundwater and renew the water resources of the Mekong River. These factors maintain the water quality of the Mekong River in a good condition that does not have serious impacts on riparian residents. Therefore, the necessity to improve water quality in the Mekong River basin is not very urgent. This situation is reflected in the fact that the Water Quality Procedure is merely a framework and does not include detailed arrangements to effect water quality improvement.

\subsubsection{Fishery and Industry}

\subsection{Fishery}

There is no specific instrument for the function of fishery in the Rhine water regime. The fishery function of the Rhine water regime is reflected in the work of the "Salmon 2020" Programme, ${ }^{662}$ as well as in measures for the sustainable development of migratory fish. ${ }^{663}$ The aim of the function of fishery in the Rhine water regime is biodiversity conservation and ecosystem protection. In accordance with this aim, several measures to reduce illegal fish catches in the Rhine River basin have been adopted. According to goals of the Rhine 2020, which is to conserve the ecosystem of the Rhine River basin, this function can also be related to issues of climate change,

\footnotetext{
${ }^{662}$ ICPR, 'Salmon 2020' (Official Website of the ICPR) < http://www.iksr.org/en/internationalcooperation/rhine-2020/salmon-2020/index.html> accessed 2 October 2016.

${ }^{663}$ ICPR, '166. und 167. Effectiveness of measures for a successful and sustainable reintroduction of migratory fish in the Rhine watershed' (Official Website of the ICPR) <http://www.iksr.org/en/documentsarchive/technical-reports/reports-and-brochures-individualpresentation/artikel/462/index.html> accessed 2 October 2016.
} 
water quality, nature protection, and so forth. ${ }^{664}$ Conversely, in the Mekong water regime, there is a specific Programme for the function of fishery, namely the Fisheries Programme, which pushes for efforts to support the sustainable development of fishery in the Mekong river basin, improves people's awareness of the issue and their fishery skills, as well as to foster trans-boundary cooperation for improved fishery management. ${ }^{665}$

One reason for the diverging aims of the respective fishery function in these two regimes is the differing role that fishery plays in each of them. In the Mekong region, fishery is essential for local people's livelihoods and national economic growth, while in the Rhine River basin fishery is neither a main source of residents' income nor a pillar of the national economy. Another relevant reason for this situation is the contrasting focus of the two water regimes. The Mekong water regime states that its primary goal is to foster the sustainable development of the Mekong River basin, which is a pluralist goal that includes several aspects based on a core component, namely the Mekong water resources. Hence, the functions of the Mekong water regime are also pluralist and not only concerned with environmental aspects but other relevant aspects, such as social and economic development, as well. The Rhine water regime, in contrast, is a more professional regime for water resource protection and ecological conservation, and its primary aim is to reach a "good status" of the water bodies in the Rhine river basin district. Therefore, the functions of the Rhine water regime also focus chiefly on environmental protection and ecosystem conservation.

\subsection{Industry}

Industrial development in the Rhine River basin began in the second half of the $19^{\text {th }}$ century. Thereafter, the Rhine River became a vital basis for heavy industry as well as the chemical and textile industries. On the one hand, the Rhine River serves as an important means of transporting raw materials and goods. On the other, the Rhine River is also a vital source of cooling and process water and a way of discharging

\footnotetext{
${ }^{664}$ ICPR, 'Rhine 2020 - Program on the sustainable development of the Rhine' (Official Website of the ICPR) <http://www.iksr.org/en/international-cooperation/rhine-2020/index.html> accessed 28 October 2016.

${ }^{665}$ MRC, 'Fisheries Programme' (Official Website of the MRC) <http://mrcmekong.mrcdev.info/about-mrc/completion-of-strategic-cycle-2011-2015/fisheriesprogramme/> accessed 2 October 2016.
} 
wastewater. Therefore, the Rhine River basin is a region famous all over the world for its high density of industrial plants, ${ }^{666}$ which have also caused serious pollution, including to the drinking water supply and the aquatic ecosystem, in the past. ${ }^{667}$ Thanks to activities of the Rhine Action Programme by the ICPR, this pollution has been significantly reduced since the end of the $1970 \mathrm{~s} .{ }^{668}$ Besides pollution reduction, there are also other measures for enhancing the prevention of accidents and security of industrial plants laid down in the Warning and Alarm Plan, as well as for stocking hazardous substances and constructing retention basins for firefighting water. ${ }^{669}$ The legal basis of the Rhine water regime also has an effect on the discharge from industry. For instance, the WFD's goal of achieving a "good status" of the Rhine's water bodies consists of securing "ecological good status" and "chemical good status", both of which are related to controlling industrial pollution.

Compared with the Rhine water regime, the Mekong water regime can hardly be said to have an industrial function. This seems to only manifest itself in issues of water quality improvement and fisheries management. Moreover, there is no specific instrument to discuss industry and its impacts in the Mekong River basin. The reason for this difference is the different degree of industrial development. In the Mekong River basin, the industrial development is still in an initial stage, and current water quality is still good. Therefore, the pollution from industry has not been emphasized in the Mekong water regime. In the experience of the Rhine River basin, however, recovering high water quality and restoring the ecosystem is a huge project that will take a long time to realize and require a large amount of money and human resources. Preventing potential pollution is thus preferable over cleaning up pollution that has already occurred. The Mekong water regime should therefore begin taking this issue into consideration, especially in these times of rapid development.

\footnotetext{
${ }^{666}$ ICPR, 'Industry' (Official Website of the ICPR) < http://www.iksr.org/en/uses/industry/index.html> accessed 2 October 2016.

${ }^{667}$ Ibid.

${ }^{668}$ Thomas Bernauer, Peter Moser, 'Reducing the Pollution of the River Rhine: The Influence of International Cooperation' (1996) 5/4 The Journal of Environment Development 389, 389.

${ }^{669}$ ICPR, 'Industry' (Official Website of the ICPR) <http://www.iksr.org/en/uses/industry/index.html> accessed 2 October 2016.
} 


\subsection{Conclusion of the Functional Comparison}

As we have seen from the plethora of comparisons of these two water regimes, there are numerous differences in their different functions. One main difference is the different focus of each respective function. For instance, the function of agricultural development has divergent emphases in these two regimes. In the Mekong water regime, the agricultural function focuses on the relationship between agriculture and people's livelihood, while the agricultural function in the Rhine water regime focuses on agricultural pollution control and aims to achieve a good status of the water bodies. One reason for these discrepancies lies in the Mekong water regime's pluralist aims. The MRC is the only regional organization based on instruments governed by a legal framework (namely, the 1995 Mekong Agreement) that focuses on the Mekong River and its water resources, and it assumes the task of furthering the Mekong River's sustainable development. Therefore, the MRC is not only responsible for environmental missions in the Mekong River basin, but also social and economic development. Consequently, functions of the MRC also reflect the pluralist aim of the Mekong water regime and do not merely focus on environmental protection. Comparatively, the focus of the Rhine water regime is on environmental protection, which aims to improve the water bodies' status and the related ecosystem, and hence the different functions of Rhine water regimes all serve this aim.

Another reason for the divergence in these two regimes is the different degree of development of the two river basins. The Mekong River basin is a typical developing region. Most of the riparian countries are developing countries and a large number of residents in this region still live in poverty. Therefore, the primary concern in the Mekong River basin is still the economic growth, which is related to local people's livelihoods, national development and regional stability. Environmental issues here can be an important and beneficial aspect when considering how to foster the economic growth, but they are not a priority above and beyond economic growth. In contrast, the Rhine River basin is a more developed region, and the riparian countries are mostly developed countries. Economic growth is still important but not the primary goal for this region. Environmental protection is becoming increasingly more important and is considered an issue that will affect the future sustainability of the region. The residents in this region are mostly living in good conditions, and are more concerned with "environmental comfortableness" than how the environment affects 
their livelihoods. Against this background, the Rhine water regime pays more attention to river environmental protection and water resource conservation. This background is also a very suitable basis for implementation of the related instruments. Another major discrepancy becomes apparent when comparing the implementation of the instruments of these two regimes. The implementation of the relevant instruments in the Mekong water regime is not so effective. On the contrary, in the Rhine water regime, relevant instruments can be implemented more effectively. The reason for this discrepancy is the different legal basis of these two regimes. The legal basis for the Mekong water regime is the 1995 Mekong Agreement, which is also its only legally binding basis. It is a highly vague and abstract framework for the sustainable development of the Mekong River basin with only general regulations. Hence, although it is legally binding, it still can hardly guide the relevant instruments to improve their implementation. In comparison, the legal basis of the Rhine water regime is more comprehensive and effective, consisting of three main legal instruments, namely the Rhine Convention, the EU WFD, and the EU Floods Directive. These instruments are all legally binding and have effective implementation mechanisms. Therefore, they can provide a good stage for the implementation of the Rhine water regime's different functions. Additionally, with the exception of the ICPR, the European Union is also a powerful regional organization that is devoting a series of efforts to the implementation of the Rhine water regime's functions.

A number of regional characteristics can also affect the functions of the water regime. For instance, the local climate can be a typical element that could affect the regional water regime's functions. In the Mekong River basin, the local climate belongs to the "tropical monsoon" category, which causes obvious dry seasons and wet seasons for the Mekong River basin and hence regularly causes floods and drought. The Mekong water regime's flood and drought function is therefore very crucial for regional sustainable development, and should focus mainly on the management of floods and droughts due to their certainty. The local climate in the Rhine River basin is relatively mild, and normally would not bring serious floods and droughts. This function thus places greater emphasis on flood prevention and low water control.

In summary, even at the surface level, the functions of these two water regimes have the same name, but in fact they differ to an extensive degree in terms of their content 
because of the different aims of the regimes, different degrees of regional development, different legal basis of their water regimes, and also their differing regional characteristics. All in all, the implementation of the regime's functions in the Rhine River basin is more effective than in the Mekong River basin, from which we can conclude that, despite their differences, the latter could learn a great deal from the former. 


\section{Chapter 4. Improvement of the International Legal Water Regime of}

\section{the Mekong River Basin}

The analyses in previous chapters provide us sufficient information of the Mekong water regime and its functions in reality. It is a vital foundation for the following discussion on the improvement of the Mekong water regime. The assessment of the 1995 Mekong Agreement exposes its main disadvantage as it is too abstract and vague. Therefore the author uses the 1997 UNWC as a model for the improvement of this Agreement. Also institutional improvement based on the functional comparison and the consideration of complicated relationships in the Mekong water regime has also been illustrated in this chapter. Moreover as the most upstream country, the role of China is also decisive for the future development of the Mekong water regime. Hence, to discuss involvement of China into this regime is also quite meaningful. This chapter draws a clear picture for how to improve the Mekong water regime, and presents three different aspects of the improvement, namely to strengthen its legal basis, to enhance its institution, and to involve China into it.

\subsection{The 1997 UNWC as an Important Basis for the Improvements}

The 1997 UNWC entered into force on $17^{\text {th }}$ of August in 2014 following its ratification by Vietnam. This was a very crucial step for the Mekong water regime as well as for international water law at large, and Vietnam's decision also connected this famous international multilateral convention with the Mekong River basin. After this point, the relationship between the Mekong water regime and the 1997 UNWC could no longer be ignored. To some extent, especially after it entered into force, the 1997 UNWC gained a position as a recognized codification of customary international law. ${ }^{670}$ Some content of the Convention is a direct reflection of general customary international law that is binding upon the international community as a whole, for instance, the principle of the equitable use. ${ }^{671672}$ It becomes clear that this Convention could play and continues to play an important role in different aspects of the Mekong water regime, the details of which will be expressed in the following.

\footnotetext{
${ }^{670}$ Owen McIntyre, 'Utilization of shared international freshwater resources - the meaning and role of “equity” in international water law' (2013) 38/2 Water International 112, 112.

${ }^{671}$ Ibid.

${ }^{672}$ Alina Kaczorowska-Ireland, Public International Law (UK, 5th, Routledge, 2015) 31.
} 


\subsubsection{Introduction of the 1997 UNWC}

\subsubsection{Historical Background}

At the beginning of the $20^{\text {th }}$ century, the non-navigational utilization of the fresh water resources began to become an ever more important international legal issue. ${ }^{673}$ Countless disputes on the utilization of natural freshwater resources took place against this background, which raised the state communities' awareness of the importance of the freshwaters. ${ }^{674}$ The riparian countries of international watercourses therefore required relevant regulations for this issue, which also had to rely on general principles of international law. ${ }^{675}$ The General Assembly of the UN (GA) thus decided to adopt measures involving international water resources law, and on 8th December 1970, the GA entrusted the International Law Commission (ILC) with the task of "tak[ing] up the study of the law of the non-navigational uses of international watercourses with a view to its progressive development and codification". ${ }^{676}$

The ILC's work made the question of the equitable apportionment of freshwater the top priority. In 1991, the ILC presented a draft of "The law of the Non-Navigational Uses of International Watercourses", which included 32 draft articles based on the principle of restricted territorial sovereignty. ${ }^{677}$ These draft articles were transmitted to governments for comments and observations. ${ }^{678}$ Then, in July of 1994, the ILC finished the second reading of the draft articles based on the comments and debates from the GA, and made some crucial changes for the 1991 draft articles. For instance, the ILC added another article, Article 33, to regulate the settlement of disputes and fundamentally amend Article $7 .{ }^{679}$

\footnotetext{
${ }^{673}$ Attila Tanzi and Maurizio Arcari, The United Nations Convention on the Law of International Watercourses (Netherlands, 1st, Kluwer Law International, 2001) 6-7. Negotiations' (2002) Technical University of Berlin Institute for Landscape and Environmental Planning: Working Paper on Management in Environmental Planning 4/2002, 16 <http://www.planenbauen-umwelt.tu-berlin.de/fileadmin/a0731/uploads/publikationen/workingpapers/wp00402.pdf> accessed 29 September 2016.

${ }^{676}$ Schroeder-Wildberg (n 675) 16.

${ }^{677}$ Tanzi and Arcari (n 673) 40-41.

${ }^{678}$ Tanzi and Arcari (n 673) 41.

${ }^{679}$ Ibid.
} 
Subsequently, the Sixth Committee, which is one of the 6 main committees of the GA and the primary forum for dealing with legal questions, took over this task from the ILC. Thereupon, it convened as a working group to elaborate a framework convention based on the draft articles of the ILC as well as the written comments and observations of the States. ${ }^{680}$ After two rounds of negotiations, the Sixth Committee submitted the final version of the UNWC, which was adopted on 21st May 1997.

\subsubsection{Contents}

The UNWC consists of a preamble, 37 articles and an annex. The 37 articles are divided into 7 parts. Former 33 of these are regarded as substantive content, while the other 4 articles are procedural articles. ${ }^{681}$

The Preamble expresses the aim of the UNWC, and points out that the UNWC is a framework convention. ${ }^{62}$ The first 4 Articles constitute Part I, in which the scope of this convention, the definition of the watercourse and the watercourse States is laid out. Article 3 states that this Convention will not affect other existing regional watercourse agreements. Article 4 expresses the right of every state to participate in the negotiation of regional agreements. ${ }^{683}$ Part II contains general principles of the UNWC, which are the most important fundament for this Convention. These principles include: equitable and reasonable utilization and participation, the obligation not to cause significant harm, the general obligation to cooperate, the regular exchange of data and information, and the stipulation that "no use of an international watercourse enjoys inherent priority over other uses" ${ }^{684}$ Part III provides a procedure for combatting possible negative effects of the watercourse states' planned measures on a watercourse or other riparian countries. Article 11 regulates information exchange in the context of planned measures. Notification in the context of planned measures with possible adverse effects is stipulated by Article 12. Articles 13-18 provide periods for replies to notifications, and also introduce regulations and procedures given absence. The notifying state must cooperate and interrupt the implementation of the planned measures during the reply period for the notification.

\footnotetext{
${ }^{680}$ Schroeder-Wildberg (n 675) 18.

${ }^{681}$ McCaffrey (n 160) 302.

${ }^{682}$ The 1997 UNWC (n 169) Preambel.

${ }^{683}$ The 1997 UNWC (n 169) art 1-4.

${ }^{684}$ The 1997UNWC (n 169) art 5-10.
} 
Article 19 establishes a procedure for urgent implementation of planned measures. ${ }^{685}$ The major obligations of environmental protection have been elaborated in Part IV, at the beginning of which Article 20 explicitly expresses that "the watercourse States shall, individually and, where appropriate, jointly, protect and preserve the ecosystems of international watercourses". ${ }^{686}$ Articles 21-23 concern themselves with issues of pollution, alien and new species, and the marine environment. Article 24 dictates that the international watercourses be managed jointly, and includes a plan for their sustainable development. Article 25 stipulates cooperation that the need for regulating the watercourse's flow arises. Finally, Article 26 requires each state has to ensure the safe operation and maintenance of its installations, facilities and other works related to an international watercourse. Part V, then, consists of Articles 27 and 28, which deal with harmful conditions and emergency situations. Part VI comprises Articles 29 to 33 and provides miscellaneous provisions for international watercourses and installations in times of armed conflict, indirect procedures, data and information vital to national defense or security, non-discrimination, as well as a very important and detailed provision for the settlement of disputes (Article 33). ${ }^{687}$ Part VII is the final clause and contains Articles 34 to 37. Article 34 specifies the time of the opening and signature of the Convention. The Secretary General is accounted the role of "depository for the instruments of ratification, acceptance, approval or accession" in Article 35. Article 36 dictates the Convention's entry into force, and the final article stipulates the different languages into which the Convention must be translated. ${ }^{688}$ Lastly, the Annex lists steps to be taken in emergencies or during times of conflict, though this may only take place given a consensus is arrived at between the conflicting parties and the dispute is submitted to arbitration. ${ }^{689}$

\subsubsection{The Most Contentious Articles: Articles 5 and 7}

The most contentious articles of the Convention are Articles 5 and 7 from the part on general principles.

\footnotetext{
${ }^{685}$ The 1997 UNWC (n 169) art 11-19.

${ }^{686}$ The 1997 UNWC (n 169) art 20.

${ }^{687}$ The 1997 UNWC (n 169) art 29-33.

${ }^{688}$ The 1997 UNWC (n 169) art 34-37.

${ }^{689}$ The 1997 UNWC (n 169) Annex.
} 
Article 5 consists of two paragraphs and describes the principle of "equitable and reasonable utilization and participation". The first paragraph introduces the terms "equitable" and "reasonable", and states that water resources should be utilized in an "optimal and sustainable" manner based on the aim of environmental protection. ${ }^{690}$ The word "optimal" has been discussed extensively to its different connotations in the respective countries. The word "sustainable" has been a topic of discussion as well, for similar reasons. The second paragraph discusses the "use, development and protection" of an international watercourse basin, with a focus on riparian states' rights and duties, and introduces the idea of watercourse protection based on the common management of riparian countries as well. ${ }^{691}$ Unfortunately, this idea also produced a certain amount of ambiguity, namely that the extent of the protection pertains merely to the watercourse itself and not to the general ecology of the river basin. ${ }^{692}$

Article 7 expresses the principle of "not [causing] significant harm". This is embodied in its first paragraph, which states specifically that all riparian states shall "take all appropriate measures to prevent the causing of significant harm to other watercourse states". ${ }^{693}$ The second paragraph describes the possibility of acceptance of currently occurring significant harm. Based on this situation, the harming state should "take all appropriate measures ... to eliminate or mitigate such harm and, where appropriate, to discuss the question of compensation". ${ }^{694}$

The contention between Articles 5 and 7 is that "equitable and reasonable utilization" and the "obligation not to cause significant harm" cannot be approached simultaneously. ${ }^{695}$ The core point of this contention is whether equitable utilization

\footnotetext{
${ }^{690}$ Peter Beaumont, 'The 1997 UN Convention on the Law of Non- navigational Uses of International Watercourses: Its Strengths and Weaknesses from a Water Management Perspective and the Need for New Workable Guidelines' (2000) 16 Water Resources Development 475, 480.

${ }^{691}$ P. W. Birnie and A. E. Boyle, International Law and the Environment (US, 2nd, Oxford University Press, 2002) 305.

${ }^{692}$ Beaumont (n 690) 481.

${ }^{693}$ The 1997 UNWC (n 169) art 7.

${ }^{694}$ The 1997 UNWC (n 169) art 7.

${ }^{695}$ Beaumont (n 690) 482.
} 
should prevail over the "no harm" obligation. ${ }^{696}$ The solution to this debate is reflected in the second paragraph of Article 7, which gives precedence to equitable utilization over the doctrine of "no harm". This paragraph implicitly acknowledges that harm may be caused without the existence of any responsibility on the part of the harming state ${ }^{697}$ It also indicates that significant harm may have to be endured by a riparian state on account of a series of mitigation clauses and the phrase "having due regard for the provisions of Articles 5 and $6 .{ }^{1698}$ Article 10 also makes reference to these two articles, and additionally states that conflicts based on riparian states' different uses will not be solved on the basis of Article 7 alone, but rather through "package" articles stipulating both the principle of equitable and reasonable utilization and that of the "no harm" obligation. ${ }^{699}$ According to the case of Gabcikovo-Nagymaros, this quandary can be solved by cooperation and compromise on the part of the parties involved, not merely "by rigid insistence on rules of law". ${ }^{700}$

\subsubsection{Functions of the 1997 UNWC}

The 1997 UNWC has many important functions reflected in a plethora of different aspects. In addition to the functions it originally fulfilled, its entry into force brought about additional functions as well. As a recognized authoritative codification of customary international water law, some of its content could have impact on not only its parties but also to non-parties. ${ }^{701}$

Firstly, the Convention inspired negotiations on watercourse agreements. The Convention includes a series of standards, such as the principle of equitable and reasonable use and participation, the prevention of harm, the duty to protect the ecosystem of international watercourses, the procedural rules on planned measures, and dispute settlement mechanisms. These standards can be applied and adjusted to unique characteristics of an international watercourse and to the needs of basin

\footnotetext{
${ }^{696}$ Stephen C. McCaffrey, 'An overview of the UN Convention on the Law of the Non-Navigational Uses of International Watercourses' (2000) 20 J. Land Resources \& Envtl. L. 57, 63.

${ }^{697}$ Stephen C. McCaffrey, 'The Convention Enters Into Force' (2014) 44/4 Environmental Policy and Law 351, 352-353.

${ }^{698}$ McCaffrey (n 696) 64.

${ }^{699}$ Ibid.

${ }^{700}$ Ibid.

${ }^{701}$ Flavia Rocha Loures and Alistair Rieu-Clarke (eds), The UN Watercourse Convention in Force: Strengthening International Law for Transboundary Water Management (UK, 1st, Routledge, 2013) 64.
} 
states. ${ }^{702}$ The scope of this function consists of two aspects. Firstly, it can foster the adoption of new legal instruments for instances where has no existing treaties or where existing treaties must be supplemented. Secondly, it is an aid to the revision of existing treaties that are "outdated, weak or inequitable". ${ }^{703}$ Given the entry into force of this Convention, it is likely that it will have a wider and deeper influence on the process of negotiating treaties between the riparian states. ${ }^{704}$ On the one hand, the Convention's entry into force can enhance the stakeholders' awareness of this Convention; on the other, although it has only been accepted by 36 member states, the Convention can still be a point of departure for negotiations on international watercourses issues. ${ }^{705}$ Additionally, the entry into force of this Convention also establishes a tendency towards consistency for watercourse agreements between the riparian states, ${ }^{706}$ because the Convention can provide "a certain degree of stability to the process of creating regional agreements". ${ }^{707}$

Secondly, the Convention can aid parties in the application and interpretation of watercourse agreements; ${ }^{708}$ this is because a watercourse agreement is not isolated, but rather is supported and limited by (as well as tested against) a series of other international standards. ${ }^{709}$ Therefore, various developments in the law may be related to the treaty's interpretation, and the principles and rules of a larger legal system can make the conventional law of a watercourse more effective. ${ }^{710}$ The UNWC is also a source of international standards, and plays an important role especially in the interpretation of contentious provisions, as well as in the application of outdated treaties that require improvement given modern developments. "It has provided a basic framework for arbitral and judicial decision-making", and its entry into force can enhance its authority, raise the public's awareness of its contents, and also

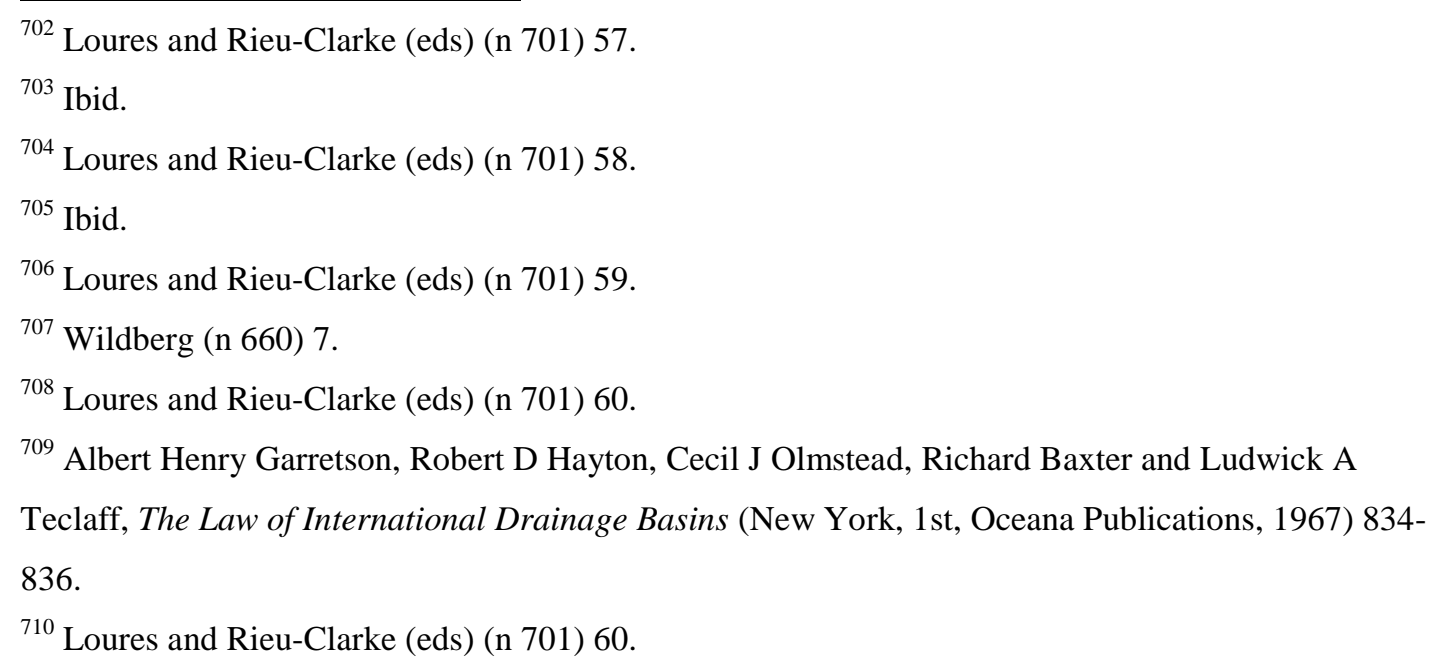


develop knowledge relevant to its content and functions. ${ }^{711}$ Thanks to its entry into force, the possibility for states and judges to invoke this Convention as a basis for supporting the interpretation and application of existing treaties may also increase.

The third function of the UNWC is that it can govern interstate relations in the absence of applicable agreements. ${ }^{712}$ The Convention contains a lot of principles that are reflections of customary international law, which are also binding for all states. ${ }^{713}$ When there is no other applicable watercourse agreement for an international watercourse, the Convention can serve as a binding legal basis for deciding the rights and duties of the watercourse states that are parties to it. ${ }^{714}$ Substantively, the Convention provides a common stage to govern relations among parties, and can, to some extent, prevent disputes. Procedurally, it states the importance of the consideration of mutual benefits and good faith by cooperation. ${ }^{715}$ In addition, it also points out, by general rule, that no watercourse state can ignore requests from other watercourse states to enter into consultation. ${ }^{716}$ Given the fact that 60 percent of the world's trans-boundary watersheds have not been regulated by agreements, the Convention could play a "regulatory" role in situations where watercourse states have become parties to the Convention but cannot arrive at a unanimous decision following negotiation, nor (pending entry into force) prolong negotiations on one or more specific treaties. In summary, the Convention covers three aspects: Firstly, it can govern interstate relations in the absence of a watercourse agreement. Secondly, it can provide a framework for the trans-boundary watershed, to which all riparian countries are parties. Thirdly, it can be a supplement to existing agreements when situations occur that are not governed by existing agreements. ${ }^{717}$

The fourth function is that the Convention can provide a widely accepted, general, authoritative and effective foundation for the codification of rules as they evolve, with a focus on governing the trans-boundary watersheds. ${ }^{718}$ The premise of this function is

\footnotetext{
${ }^{711}$ Ibid.

712 Ibid.

${ }^{713}$ Kaczorowska-Ireland (n 196) 31.

${ }^{714}$ Loures and Rieu-Clarke (eds) (n 701) 61.

${ }^{715}$ Ibid.

${ }^{716}$ Ibid.

${ }^{717}$ Loures and Rieu-Clarke (eds) (n 701) 61-62.

${ }^{718}$ Loures and Rieu-Clarke (eds) (n 701) 62.
} 
that watercourse states are already parties to the Convention, and have also agreed on the procedures for the adoption of future protocols, amendments and guidelines. ${ }^{719}$ Additionally, the Convention can also contribute to the development of relevant areas, for instance promoting public participation in trans-boundary water negotiations. Finally, the Convention can also act as an "official world forum" for policy coordination, knowledge and information sharing, experience and practice exchange in the field of management of the water resources of international watercourses.

Fifthly, the UNWC can also foster the implementation of other multilateral environmental conventions. ${ }^{720}$ It can add its value to other regulatory frameworks, and help to improve the implementation of goals under other environmental conventions formulated based on cooperation between riparian countries. This Convention can also enable its parties "to engage with implementing bodies under other related environmental agreements" ${ }^{721}$, as well as build synergies to avoid repetition and coordinate implementation efforts. ${ }^{722}$ For example, the watercourses states that are party to both the UNWC and the CBD can establish cooperative efforts for ecosystem protection based on the relationship between water resource management and the ecosystem approach. ${ }^{723}$

Last but not the least, the UNWC could also bring some legal and political effects to non-parties, because its entrance into force makes the non-parties taking it more seriously as a codification of customary international water law. ${ }^{724}$ Customary international law consists of two elements: one is "a relatedly uniform and constant state practice", and another element is "the subjective conviction of a State that it legally bound to behave in a particular way in respect of particular situation, or the acceptance of the practice as law by a State" ${ }^{725}$ Customary international law can be general and regional, and the general customary international law is binding upon the international community. ${ }^{726}$ But regional customary international law can supplement

\footnotetext{
${ }^{719}$ Ibid.

${ }^{720}$ Loures and Rieu-Clarke (eds) (n 701) 63.

${ }^{721}$ Ibid.

${ }^{722}$ Ibid.

${ }^{723}$ ibid 63-64.

${ }^{724}$ McCaffrey (n 697) 355.

${ }^{725}$ Kaczorowska-Ireland (n 196) 30.

${ }^{726}$ Kaczorowska-Ireland (n 196) 31.
} 
or derogate the general one. ${ }^{727}$ The basic knowledge of the customary international law can also prove that the effects of the 1997 UNWC can broaden to non-parties, based on some situations. There are two situations that a treaty can be effective to non-parties. One situation is some of its contents have already been recognized as customary international law. Another situation is that the non-parties have showed their consent by expression or implication to the content of that treaty. ${ }^{728}$ As an authoritative codification of international customary law, the Convention can have an important influence on state practice. Except situations mentioned above, the Convention's entry into force would enhance its legal and political authority, thereby allowing it to have a more effective and persuasive force on non-parties. ${ }^{729}$ In practice, these effects are reflected in three aspects. First of all, the UNWC could play act as "a complementary, mutually reinforcing legal framework" for non-parties' negotiations on international watercourse uses. ${ }^{730}$ Moreover, it would also have an impact on nonparties' interpretation and application of watercourse agreements and related customary international law. ${ }^{731}$ Finally, the Convention would accelerate the process of consolidating complementary provisions as part of international custom, and this process would also strengthen the binding effect of the Convention on non-parties. ${ }^{732}$ In summary, the UNWC carries out a series of functions reflected not only by its parties, but by non-parties as well. Its entry into force is a vital step towards its further development, which would enhance its legal and political authority. In the future, it will continue to play a consistently important role as one of the most significant authoritative manifestations of customary international law, and a framework in the style of which other bilateral and multilateral agreements can be formulated and interpreted. ${ }^{733}$

\footnotetext{
${ }^{727}$ Ibid.

${ }^{728}$ Kaczorowska-Ireland (n 196) 104-106.

${ }^{729}$ Loures and Rieu-Clarke (eds) (n 701) 64.

${ }^{730}$ Ibid.

${ }^{731}$ Ibid.

${ }^{732}$ Loures and Rieu-Clarke (eds) (n 701) 65.

${ }^{733}$ Gabriel Eckstein (ed), 'Specially invited opinions and research report of the International Water Law Project: global perspectives on the entry into force of the UN Watercourses Convention 2014: part two' (2015) 17 Water Policy 162, 183.
} 


\subsubsection{Reasons to Choose the 1997 UNWC as a Basis for the Improvement}

Upon ratification by Vietnam, the 1997 UNWC had a sufficient number of ratifying parties to enter into force. As already mentioned above, its entry into force enhanced its legal and political authorities, and therefore also improved its effect on the development of international water law. As a crucial river basin in South East Asia, the Mekong River basin plays a significant role in regional development. The management of trans-boundary water resources in the Mekong River basin also has numerous aspects needing improvement. Vietnam's ratification made it the first country from the Mekong River basin to become party to the 1997 UNWC. At the same time, this ratification combined this famous international convention together with the Mekong River basin. This background drew the author's attention to the effects of the 1997 UNWC after its entry into force, and the author has determined that there are a number of reasons for utilizing this Convention as a basis for improvement of the Mekong international legal water regime.

Firstly, the entry into force of the 1997 UNWC generated international pressure for commitment to share an international river based on international norms in the Mekong Region. ${ }^{734}$ The 1997 UNWC was able to promote the countries' adherence because it is a "codification and progressive development" of international customary law. ${ }^{735}$ The UNWC was therefore also able to enhance Mekong regional cooperative decision-making, demand management, as well as joint sustainable investment. ${ }^{736}$ These impacts have proved to be capable of consistently leading Mekong regional development in a more effective and equitable direction. ${ }^{737}$ To some extent, the international pressure created by the UNWC was also able to ensure specific state behaviors, thereby enhancing Mekong regional legal security and mitigating the risk of water resources-related disputes. ${ }^{738}$

Secondly, several substantive and procedural provisions from the 1997 UNWC were capable of supplementing the current legal basis of the Mekong water regime. ${ }^{739}$ The 1997 UNWC provides a general framework for international watercourse protection

\footnotetext{
${ }^{734}$ Pech (n 284) 78-79.

735 Ibid.

${ }^{736}$ Ibid.

${ }^{737}$ Ibid

${ }^{738}$ Ibid.

${ }^{739}$ Pech (n 284) 51.
} 
and management. It contains provisions for protection of the groundwater and marine environment that had not been mentioned by the 1995 Mekong Agreement. ${ }^{740}$ The provisions of equitable and reasonable utilization and the obligation not to cause significant harm dictated by the Convention, as well as the principle of the sustainable development, are more detailed than those in the 1995 Mekong Agreement. ${ }^{741}$ The Convention also explicitly emphasizes the protection and preservation of the ecosystem, as well as the reduction and control of pollution, as well as the control of alien species. It offers a more ecosystem-oriented approach to the implementation of the 1995 Mekong Agreement. ${ }^{742}$ Furthermore, the Convention includes a comprehensive, step-by-step process for dispute settlement and stipulates the principle of non-discrimination. These constitute advanced examples of the Mekong Agreement's improvement. ${ }^{743}$ In the comparison between the 1997 UNWC and the 1995 Mekong Agreement, these points will be explained in greater detail.

Thirdly, according to the functions of the 1997 UNWC illustrated in the section above, the highly effective 1997 UNWC can bring the Mekong river basin a series of additional benefits in the long run if the other Mekong countries become parties to this convention ${ }^{74}$ Firstly, ratifying this convention can save costs deriving from noncompliance with international environmental agreements. ${ }^{745}$ Moreover, the ratification of this Convention can to some extent prevent environmental harm, and therefore save the cost of recovering from that harm in the future, ${ }^{76}$ bringing long-term economic benefits. Furthermore, ratifying this Convention could facilitate changes in domestic environmental law, as well as inspire negotiation on relative rules for implementing the Mekong Agreement. ${ }^{747}$ Additionally, the 1997 UNWC can promote greater transparency and participatory direction in the decision-making process, as well as within the context of the regime's accountability and dispute resolution. ${ }^{748}$ Even

\footnotetext{
${ }^{740}$ Ibid.

${ }^{741}$ Pech (n 284) 51-52.

${ }^{742}$ Pech (n 284) 52.

${ }^{743}$ Ibid.

${ }^{744}$ Pech (n 284) 72.

${ }^{745}$ Ibid.

${ }^{746}$ Ibid.

${ }^{747}$ Ibid.

${ }^{748}$ Pech (n 284) 73.
} 
though there is only one riparian country in the Mekong River basin (namely, Vietnam) that has ratified the 1997 UNWC, because the Convention is recognized as reflection of customary international law, other riparian countries would also be affected by the Convention with respect to state practice, relative agreement interpretation and application, and so forth.

Last but not the least, the 1997 UNWC can be a tool for strengthening international relations on the international rivers in the Mekong River basin. ${ }^{749}$ The detailed contents of the Convention can help Mekong countries to solve problems caused by the ambiguity of the Mekong Agreement. ${ }^{750}$ Even though most of the Mekong countries are not parties to the Convention, as a recognized and effective reflection of customary international law, it can also affect the interpretation of the international water law to some extent. The 1997 UNWC also emphasizes the importance of international cooperation, especially the duty to engage in information exchange and notification. Moreover, in addition to the MRC, the 1997 UNWC may also facilitate the work of other relative initiatives, such as those from GMS and ASEAN, and therefore can promote the development of regional water regimes based on advanced interstate cooperation. ${ }^{751}$

\subsubsection{Points Requiring Improvement based on the Comparison of the 1997 UNWC with the 1995 Mekong Agreement}

\subsubsection{Groundwater}

Groundwater is a crucial component of freshwater resources; nearly 97 percent of the available liquid freshwater on the planet is stored in aquifers found underground. ${ }^{752}$ Although chiefly utilized as a supply of drinking water, groundwater is also used for industrial and agricultural irrigation. ${ }^{753}$ In addition to these functions, groundwater also plays an important role in the environmental balance, as it is the core element of

\footnotetext{
${ }^{749}$ Pech (n 284) 74.

${ }^{750}$ Ibid

${ }^{751}$ Pech (n 284) 75.

${ }^{752}$ Burchi, Stefano and Mechlem, Kerstin, Groundwater in International Law Compilation of Treaties and Other Legal Instruments (Rome, 1st, UNESCO and FAO, 2005) Foreword, <SSRN:

https://ssrn.com/abstract=1259042> accessed 31 October 2016.

753 Ibid.
} 
the hydrological cycle and regulates the river's flow in different periods. ${ }^{754}$ Due to the slow movement of groundwater, any pollution that it is exposed to can remain for long periods. Some water pollution that occurred ten or more years ago can still be monitored in groundwater today. Therefore, the emphasis of groundwater protection should be on preventing pollution in the first place, not on cleaning it up after it has already occurred. ${ }^{755}$ There are various reasons why groundwater pollution occurs. One main reason is that river water pollution is transferred to groundwater during the hydrological cycle. ${ }^{756}$ Because of this symbiotic connection between surface water and groundwater, we should also take the protection of the groundwater into consideration when discussing the conservation of river water resources.

The 1997 UN Watercourse Convention describes the specifics of groundwater protection in Article 2, where it also provides a definition of watercourses. Specifically, Article 2 (a) states that a watercourse is "a system of surface waters and groundwater constituting by virtue of their physical relationship a unitary whole and normally flowing into a common terminus". ${ }^{757}$ The 1995 Mekong Agreement, on the other hand, makes no mention of groundwater protection, but rather only protection of the environment and the ecosystem as a general goal. In Chapter II of the 1995 Mekong Agreement, there are definitions of several special terms. The "environment" is defined within the scope of environmental protection. This encompasses "the conditions of water and land resources, air, flora, and fauna that exists in a particular region", yet did not specify groundwater protection. In conclusion, given the important role of groundwater in many different respects, the 1995 Mekong Agreement should address this issue by discussing water resources management in the Mekong River basin.

\subsubsection{Good Faith}

According to Friendly Relations Declaration drawn up in the 1960s, good faith has a high moral meaning, and has been treated as a foundation of the international legal

\footnotetext{
${ }^{754}$ European Commission, 'Groundwater' (Official Website of the European Commission) <http://ec.europa.eu/environment/water/water-framework/groundwater/resource.htm> accessed 02 October 2016.

755 Ibid.

${ }^{756}$ J. J. Fried, Groundwater Pollution (Netherland, 1st, Elsevier Science, 1975) 1-2.

${ }^{757}$ The 1997 UNWC (n 169) art 2.
} 
order. ${ }^{758}$ It is an important element for both substantial and procedural law. ${ }^{759}$ To some extent, the non-legally binding instruments, which include the UNGA resolutions and other forms of soft law, must also to be considered in good faith. ${ }^{760}$ Good faith is not only a kind of constitutional quality of international law, but can also be a vital foundation of all law. ${ }^{761}$ Good faith is a very broad and abstract concept, and may therefore "contain the risk of too ambitious judicial activism". ${ }^{762}$ Nowadays, international law finds itself in a very active and dynamic situation, and the relative interpretation of international law should also be dynamic and evolutionary due to its crucial role for its effective implementation. ${ }^{763}$ In this dynamic process, good faith assumes a "gap-filling" function, and consent must consistently be obtained anew. ${ }^{764}$ In the 1997 UNWC, good faith is mentioned in Articles 3, 4, 8, 17, 31 and 33. These articles point out that good faith is important for cooperation, negotiation, consultation, data and information exchange, as well as dispute settlement. In contrast, the Mekong Agreement's provisions make no mention of good faith. Despite this, we can assume that good faith has also been considered in negotiations, cooperative efforts, and dispute settlements within the context of the 1995 Mekong Agreement and activities of its Programmes and its projects. ${ }^{765}$ Regardless, it is better to remind parties of this foundation in the text of the legal basis. ${ }^{766}$

\footnotetext{
${ }^{758}$ Markus Kotzur, 'Good Faith', Max Planck Encyclopedia of Public International Law (Fall edn 2009), Paragraph 25 <http://opil.ouplaw.com/view/10.1093/law:epil/9780199231690/law9780199231690-e1412?rskey=SppiOc\&result=1\&prd=EPIL> accessed 2 October 2016.

${ }^{759}$ Ibid.

${ }^{760}$ Ibid.

${ }^{761}$ Ibid.

${ }^{762}$ Kotzur (n 758) Paragraph 26.

763 Ibid

${ }^{764}$ Ibid.

${ }^{765}$ The Mekong Research Group, “"Attachment 3: The Legal Framework for Mekong Water

Governance" to the Report of National Interest and Trans-boundary Water Governance in the Mekong' (2006) Australian Mekong Resource Centre at The University of Sydney in collaboration with Danish International Development Assistance, 9

<http://sydney.edu.au/mekong/documents/mekwatgov_att3.pdf> accessed 29 September 2016.

766 ibid.
} 


\subsubsection{Equitable and Reasonable Utilization}

The equitable and reasonable utilization of the water resources in an international watercourse is always the most important and controversial issue. It is also a fundamental principle for trans-boundary water resources management and protection. According to the comparison between the 1997 UNWC and the 1995 Mekong Agreement, there are several differences between the interpretations of equitable and reasonable utilization in these two legal instruments.

First of all, this principle has been mentioned in Article 5 of the 1997 UNWC as well as in the 1995 Mekong Agreement. Article 5(2) of the 1997 UNWC states that "watercourse States shall participate in the use, development and protection of an international watercourse in an equitable and reasonable manner. Such participation includes both the right to utilize the watercourse and the duty to cooperate in the protection and development thereof, as provided in the present Convention" ${ }^{767}$ This means that the equitable and reasonable utilization principle in the Convention not only includes the contents of participation on international watercourse utilization, but also the contents of participation on protection of an international watercourse. In contrast, this point is not included in Article 5 of the 1995 Mekong Agreement. Article 5 of the 1995 Mekong Agreement focuses more on the utilization itself and ignores several important issues, such as the duty of protection. However, although the protection of the Mekong River is mentioned generally in other articles of the 1995 Mekong Agreement, it is still not sufficient to express the principle of equitable and reasonable utilization due to its fundamental position in international watercourse management and protection.

Moreover, in addition to Article 5 of the 1997 UNWC, Article 6 is also a relevant provision for the furtherance of equitable and reasonable utilization, listing a series of factors that must be considered in this context. These include geographical, hydrographical, hydrological, climatic, ecological and other factors related to nature and the environment, social and economic needs, dependent population, existing and potential uses of resources and the effects thereof, conservation, protection, development and economy of use and the related costs, and the availability of alternatives. ${ }^{768}$ Comparatively, Article 5 of the 1995 Mekong Agreement almost off-

\footnotetext{
${ }^{767}$ The 1997 UNWC (n 169) art 5(2).

${ }^{768}$ Pech (n 284) 56.
} 
handedly mentions these factors with a simple "all relevant factors and circumstances", which is too abstract and vague to be of any real relevance. Relative to this, however, is the fact that Article 26 of the Mekong Agreement lists several factors dealing with water utilization and inter-basin diversions, which contain some climatic, geographical and hydrological factors. We can therefore conclude that the principle of equitable and reasonable utilization as described in the 1997 UNWC is more comprehensive than that in the 1995 Mekong Agreement. Based on this, the factors listed in the 1997 UNWC should also be mentioned in the 1995 Mekong Agreement. Furthermore, these factors should also be considered for the activities of the MRC's Basin Development Plan Programme, the Water Utilization Plan and also the Environmental Programme. ${ }^{769}$

\subsubsection{Obligation not to Cause Significant Harm}

The obligation not to cause significant harm is the primary focus of Article 7 of the 1997 UNWC. It states that watercourse countries shall "take all appropriate measures to prevent the causing of significant harm to other watercourse States", and, "where significant harm is caused, the States who cause this harm shall take all appropriate measures to eliminate or mitigate the significant harm, and to discuss the question of compensation". ${ }^{770}$ The 1995 Mekong Agreement also made mention of this principle in various articles. Article 1 decreed that riparian countries shall "minimize the harmful effects", while Article 8 establishes the state's responsibility to compensate damages. These two provisions, however, are rather vague. ${ }^{711}$ Article 7 complements them as the core provision for the obligation not to cause significant harm, expressing the necessity "to make every effort to avoid, minimize and mitigate harmful effects that might occur to the environment". In fact, however, this statement is "much weaker" and not as explicit as that in the 1997 UNWC. ${ }^{772}$

\subsubsection{Relationship Between Different Kinds of Uses}

The relationship between different kinds of uses of the international watercourse has been mentioned in Article 10 of the 1997 UNWC. This provision firstly establishes

\footnotetext{
${ }^{769}$ The Mekong Research Group (n 765) 9.

${ }^{770}$ Pech (n 284) 57.

${ }^{771}$ The Mekong Research Group (n 765) 9.

${ }^{772}$ Ibid.
} 
the equity of different uses "in the absence of agreement or custom to the contrary". ${ }^{773}$ The second part of this provision emphasizes the importance of the principle of equitable and reasonable utilization and the principle of obligation not to cause significant harm, and also states that these principles are the basis for resolving conflicts between different uses. Human needs and their relationship to conflict resolution have also been taken into account in this provision. ${ }^{774}$ In contrast, this point was not specified in the 1995 Mekong Agreement. Parallel to the development of the Mekong region, the exploitation of the Mekong River has increased as well. Therefore, the relationship between different uses becomes more important, and need to be considered somehow in the Mekong water regime. For instance, the Basin Development Plan Programme and other relevant Programmes formulated by the MRC should include this element in their contents.

\subsubsection{Information Exchange and Notification of Planned Measures}

The information exchange and notification of planned measures is always a very significant topic for dealing with issues of international watercourse management and protection. The importance of this topic is reflected in the 1997 UNWC, which used 9 articles in total (Articles 11-19) to specify this topic. In contrast, the 1995 Mekong Agreement only briefly touches upon this topic in Articles 5 and 6 of their text, the articles covering equitable and reasonable utilization. Additionally, there is an instrument called Procedures for Notification, Prior Consultation and Agreement (PNPCA), which was formulated by the MRC and is non-legally binding. These Procedures include some of the contents also listed in Articles 11-19 of the Convention. Articles 24.C of the 1995 Mekong Agreement describes the functions of the MRC's Joint Committee, which also mentioned that the information exchange is an important task of the Joint Committee. The following Art 26 of the Mekong Agreement explains how the bodies of the MRC should conduct by facing situations mentioned in Articles 5 and 6.

The contents of Articles 11 and 13 of the 1997 UNWC, which establish the Watercourse States' responsibility to exchange information concerning planned measures and the period for replying to notifications, had already been mentioned in the MRC's PNPCA Procedures. Article 12 of the Convention explains the process of

\footnotetext{
773 The 1997 UNWC (n 169) art 10(1).

${ }^{774}$ The 1997 UNWC (n 169) art 10(2).
} 
notification with reference to planned measures with possible adverse effects, which was also included in the MRC's PNPCA, but the requirement of notification in the Procedures is further differentiated based on types of use, location, and season. ${ }^{775}$

All in all, there are still several points that have either not been included in or have not been expressed very comprehensively by the MRC's Procedures. Articles 14, 16, 18 and 19 of the Convention are neither reflected in the 1995 Mekong Agreement nor in the related MRC's PNPCA. Article 14 mentions the obligation of the notifying State during the reply period. It specifies that the notification "shall not implement or permit the implementation of the planned measures without the consent of the notified States". ${ }^{776}$ However, the 1995 Mekong Agreement and the PNPCA make no mention of this obligation, and does not specify whether the notifying state can implement the planned measure without permission from the notified States or not. ${ }^{777}$ Articles 16, 18 and 19 explain the absence of reply to notification, procedures in the absence of notification, and the urgent implementation of planned measures, and these points are important to elaborate in the 1995 Mekong Agreement or in relevant procedures. ${ }^{778}$ Articles 15 and 17 of the Convention express the reply to notification and consultation and negotiations concerning planned measures, which have been partially mentioned by the MRC's PNPCA and must be supplemented in concrete aspects. ${ }^{779}$

\subsubsection{Obligation to Protect and Preserve the Ecosystem}

Because water is a crucial element for sustainable development of an ecosystem, the obligation to protect and preserve the ecosystem is thus a core point of any legal instrument for protection of an international watercourse. Therefore, we can find relevant provisions in both of these two instruments.

Article 20 of the 1997 UNWC states that "watercourse States shall, individually and, where appropriate, jointly, protect and preserve the ecosystems of international watercourses." ${ }^{980}$ This is the first article of part VI, and acts as a general guideline for this part of the Convention. The Convention then uses Articles 21, 22 and 23 to

\footnotetext{
${ }^{775}$ Pech (n 284) 58-59.

776 The 1997 UNWC (n 169) art 14 (b).

${ }^{777}$ Pech (n 284) 59.

${ }^{778}$ Pech (n 284) 60-62.

${ }^{779}$ Pech (n 284) 59-61.

${ }^{780}$ The 1997 UNWC (n 169) art 20.
} 
outline three topics in greater detail. Article 21 focuses on the prevention, reduction and control of pollution. It gives a definition of the "pollution of an international watercourse", ${ }^{781}$ and also provides feasible ways for arriving at mutually agreeable measures and methods. ${ }^{782}$ Article 22 is a provision for the introduction of alien or new species. It focuses on how to prevent alien and new species from being introduced in the first place, thereby preventing harmful effects from ever happening to the ecosystem. ${ }^{783}$ Article 23 deals with the protection and preservation of the marine environment, and dictates further that all Watercourse States must take generally accepted international rules and standards into consideration when dealing with issues of estuaries and marine environments. ${ }^{784}$ In summary, the provisions of the 1997 UNWC very explicitly specify various aspects of the obligation to protect and preserve the ecosystem.

Similarly to the above, Article 3 of the 1995 Mekong Agreement also mentions the obligation to protect and preserve the ecosystem. Specifically, it establishes the obligation "to protect the environment, natural resources, aquatic life and conditions, and ecological balance of the Mekong River Basin from pollution or other harmful effects resulting from any development plans and uses of water and related resources in the Basin". ${ }^{785}$ Although it does make mention of pollution control and aquatic life protection, the wording of this provision is inadequate to have true relevance to the river's protection and the associated actions requiring enforcement. ${ }^{786}$ The MRC also formulated a non-legally binding instrument, the Procedures on Water Quality, which covers several aspects of pollution prevention, reduction, and control. ${ }^{787}$ Unfortunately, however, this non-legally binding instrument is neither sufficient nor efficient enough to solve the pollution problems at hand. As for marine environment protection and preservation, the 1995 Mekong Agreement does not include any contents of relevance. As an important connection area to the international watercourse, the marine environment is greatly affected by water discharged into the sea. In order to protect

\footnotetext{
${ }^{781}$ The 1997 UNWC (n 169) art 21(1).

782 The 1997 UNWC (n 169) art 21(3).

${ }^{783}$ The 1997 UNWC (n 169) art 22.

${ }^{784}$ The 1997 UNWC (n 169) art 23.

${ }^{785}$ The 1995 Mekong Agreement (n 138) art 3.

${ }^{786}$ The Mekong Research Group (n 765) 9.

${ }^{787}$ Pech (n 284) 62.
} 
this connection, the Mekong water regime should also consider protection of the marine environment. In conclusion, Article 3 of the Mekong Agreement is as yet still very rough; in addition to "smoothing out" the already existing content, several points should be added to make it more comprehensive.

\subsubsection{Installation}

The installations in an international watercourse have important functions for the development of the watercourse and also the riparian countries. Therefore, on the one hand, watercourse states must protect and maintain installations while simultaneously carrying out other, related works. On the other hand, if an installation or a related work of an international watercourse could cause adverse effects, the related watercourse states must enter into consultation with one another. ${ }^{788}$ Article 26 of the 1997 UNWC specifies this issue very explicitly, and at the same time mentions two elements that must be considered during any consultation. One is that the consultation should consider the safe operation and maintenance of the related installations and facilities. The other is to consider protection of installations and other related works from willful and negligent acts or natural forces. ${ }^{789}$

There is no provision related to this issue in the 1995 Mekong Agreement. While the PNPCA do include some content about consultation of watercourse states, this issue has still not been dealt with very clearly. ${ }^{790}$ To complicate matters further, these Procedures are nothing more than a non-legally binding instrument, which is very hard to be implemented. Given the fact that dam construction is now thriving in the Mekong River basin, the protection of and consultation on installations should also be taken into account by the Mekong international legal water regime. ${ }^{791}$

\subsubsection{Prevention and Mitigation of Harmful Conditions}

Potential harmful conditions for the development of an international watercourse include a series of elements, such as floods, ice conditions, water-borne diseases, saltwater intrusion, droughts and so forth. These elements can cause adverse effects that are not only harmful to the watercourse itself but also to the watercourse states

\footnotetext{
${ }^{788}$ The 1997 UNWC (n 169) art 26.

${ }^{789}$ The 1997 UNWC (n 169) art 26.2(b).

${ }^{790}$ PNPCA (n 226) 5. Consultation.

${ }^{791}$ Pech (n 284) 65.
} 
and their inhabitants. Therefore, preventing and reducing these harmful conditions is vital for the sustainable development of an international watercourse. Article 27 of the 1997 UNWC states that "Watercourse States shall, individually and, where appropriate, jointly, take all appropriate measures to prevent or mitigate conditions related to an international watercourse that may be harmful to other watercourse States, whether resulting from natural causes or human conduct". ${ }^{792}$ This article also details the scope of harmful conditions, including "flood, ice conditions, water-borne diseases, siltation, erosion, salt-water intrusion, drought and desertification". ${ }^{793}$ In the 1995 Mekong Agreement, on the other hand, there is no specification with regard to prevention and mitigation of harmful conditions. It is thus very important for the Mekong water regime to consider this issue and add it to the regime's legal basis. ${ }^{794}$

\subsubsection{Emergency Situations}

Proper consideration of how to deal with emergency situations is a very crucial step in the protection and management of an international watercourse. Emergencies not only occur as a result of forces of nature, but can also be caused by inappropriate human activities. In consideration of the paramount importance of this issue, both the 1997 UNWC and the 1995 Mekong Agreement make mention of emergency situations. Article 28 of the Convention explains this issue quite explicitly: Firstly, it defines an "emergency" as "a situation that causes, or poses an imminent threat of causing, serious harm to watercourse States or other States and that results suddenly from natural causes, such as floods, the breaking up of ice, landslides or earthquakes, or from human conduct, such as industrial accidents" ${ }^{795}$ Following the definition, the article dictates a series of obligations on the part of Watercourse States when facing emergency situations. Specifically, it states that Watercourse States shall notify, respond, and cooperate with other relevant States, and also take all necessary measures to prevent, mitigate and eliminate harmful effects of the emergency. ${ }^{796}$

Similarly, Article 10 of the 1995 Mekong Agreement also focuses on emergency situations. This article, however, is rather rough and vague in its choice of words; for

\footnotetext{
${ }^{792}$ The 1997 UNWC (n 169) art 27.

793 Ibid.

${ }^{794}$ Pech (n 284) 65.

795 The 1997 UNWC (n 169) art 28(1).

${ }^{796}$ The 1997 UNWC (n 169) art 28(2-4).
} 
example, it states that the emergency situation is a "special water quantity or quality problem", and it states that any party that is aware of an emergency "shall notify other concerned parties and the Joint Committee of the MRC in order to take appropriate remedial action". ${ }^{797}$ This wording does not sufficiently express the immediacy of emergency situations and is also inadequate for furthering cooperation between the member states when pursuing remedial action. As to be expected, the provision laid out in the 1997 UNWC is more explicit and detailed. Given that establishing a definition for "emergencies" is vital and that no such definition appears in the 1995 Mekong Agreement, this definition must be added..$^{798}$

\subsubsection{International Watercourse and Installations in Times of Armed Conflict} Article 29 of the 1997 UNWC states that, during armed conflict along the international watercourse and related installations, its facilities and other works shall be protected according to the principles and rules of international law, and shall not be used if their utilization could violate those principles and rules. ${ }^{799}$ This article also mentions the important role of the principles and rules of international law during times of armed conflict.

The 1995 Mekong Agreement also has some provisions that are related to the principles and rules of international law. Firstly, the Preamble states that the contents of the 1995 Mekong Agreement are "in conformity with the objectives and principles of the Charter of the United Nations and international law". ${ }^{800}$ Later, Article 8 makes reference to international law when it talks about state responsibility. ${ }^{801}$ When the issue of resolution by governments is addressed in Article 35 of the Mekong Agreement, the principles of the international law are mentioned as a tool for dispute settlement. ${ }^{802}$ Article 40 also touches upon principles of international law by mentioning suspension and withdrawal. ${ }^{803}$ Although many provisions make reference to principles and rules of international law, however, they do not specify the

\footnotetext{
${ }^{797}$ The 1995 Mekong Agreement (n 138) art 10.

${ }^{798}$ Pech (n 284) 66.

799 The 1997 UNWC (n 169) art 29.

${ }^{800}$ The 1995 Mekong Agreement (n 138) Preamble, Proclaiming.

${ }^{801}$ The 1995 Mekong Agreement (n 138) art 8.

${ }^{802}$ The 1995 Mekong Agreement (n 138) art 35.

${ }^{803}$ The 1995 Mekong Agreement (n 138) art 40.
} 
importance of these principles in times of armed conflict. In light of the history of the Mekong region, considerations relating to armed conflict must be elaborated on in the Mekong Agreement. ${ }^{804}$

\subsubsection{Indirect Procedures, Data and Information Vital to National Defense or Security}

Article 30 of the Convention mentions that watercourse states can use indirect procedures to fulfill their obligation of cooperation when they are facing serious obstacles to direct contact between watercourse states. ${ }^{805}$ In the 1995 Mekong Agreement, on the other hand, the issue of indirect procedures has not been included. Article 30 can be considered relevant Article 29 of the 1997 UNWC, which deals with times of armed conflict. Therefore, based on the same reason that has been expressed in former section (namely, the historical background of the Mekong water regime), the regime must also take this issue into consideration.

Article 31 of the 1997 UNWC states that the Convention has no provision for requiring watercourse states to provide data and information vital to national defense or security, but that the watercourse states shall provide "as much information as possible under the circumstances". ${ }^{806}$ This article considers not only the importance of the cooperation between watercourse states on the data and information exchange, but also the importance of national security. The 1995 Mekong Agreement also states, in the first paragraph and as well as some related articles, that the cooperation between the riparian countries is vital for the development of the Mekong River basin. Additionally, Article 4 of the Mekong Agreement also states that sovereign equity and territorial integrity is a crucial principle. Furthermore, data and information exchange also come up in Article 24 stipulating the functions of Joint Committee, as well as in the definition of notification and prior consultation. Notwithstanding, the problem is that the contents of the Mekong Agreement have not been combined together similarly to what was done in Article 31 of the 1997 UNWC, where national defense and security are specifically related to data information exchange. In addition, the obligation of providing data and information is also not explicit in the Mekong Agreement.

\footnotetext{
${ }^{804}$ The Mekong Research Group (n 765) 9.

${ }^{805}$ The 1997 UNWC (n 169) art 30.

${ }^{806}$ The 1997 UNWC (n 169) art 31.
} 


\subsubsection{Non-discrimination and Private Remedies}

The 1997 UNWC also provides provisions for private remedies with consideration of non-discrimination related to nationality or place where injury occurs when they have "suffered or are under a serious threat of suffering significant trans-boundary harm as a result of activities related to an international watercourse". ${ }^{807}$ These remedies include "access to judicial or other procedures, and a right to claim compensation or other relief'. ${ }^{808}$ In the 1995 Mekong Agreement, there is no provision detailing this issue. In fact, due to seasonal change of river flow, several pollution events and related mainstream programs, many riparian residents in the Mekong River basin have been affected. Therefore, remedies for them are necessary and meaningful for the future development of the Mekong water regime. ${ }^{809}$ Additionally, nondiscrimination of the riparian residents in an international watercourse is also a very significant point expressed in Article 32 of the Convention. Given that the 1995 Mekong Agreement did not take discrimination and its related problems into account, this constitutes an additional point where improvement is necessary.

\subsubsection{Dispute Settlement}

Due to its significance to maintaining the peace and stability of watercourse states and its importance with regard to water resource utilization, dispute settlement is always a vital issue in legal instruments for international watercourses. While Article 33 of the 1997 UNWC uses very explicit wording to address this issue, the provisions contained in Articles 34, 18.C, 24.F, and 35 of the 1995 Mekong Agreement address it in a non-comprehensive manner and must therefore be updated and improved upon. According to the provisions on dispute settlement stipulated in the 1995 Mekong Agreement, we can identify five main points. Firstly, the scope of dispute has been specified ${ }^{810}$ Secondly, when dispute occurs, the MRC shall initially make every effort

\footnotetext{
${ }^{807}$ The 1997 UNWC (n 169) art 32.

${ }^{808}$ Ibid.

${ }^{809}$ The Mekong Research Group (n 765) 10.

${ }^{810}$ The 1995 Mekong Agreement (n 138) art 34: “any difference or dispute may arise between two or more parties to this Agreement regarding any matters covered by this Agreement and/or actions taken by the implementing organization through its various bodies, particularly as to the interpretations of the Agreement and the legal rights of the parties".
} 
to resolve the dispute via its Council and Joint Committee. ${ }^{811}$ Thirdly, if the MRC was not able to resolve the dispute, relevant governments can use diplomatic channels to resolve it. ${ }^{812}$ Fourthly, mediation is a feasible way to engage in dispute settlement. ${ }^{813}$ Finally, principles of international law can also form the bases for resolving disputes. ${ }^{814}$ If we compare these five points with Article 33 of the 1997 UNWC, however, it becomes apparent that there are still several points that have not been included in the 1995 Mekong Agreement.

Firstly, the 1997 UNWC also includes submission of disputes to arbitration or to the International Court of Justice as a means of settling disputes. ${ }^{815}$ In addition to stipulating the arbitration of dispute settlements in Articles 2 to 14, the Convention also provides a relevant annex for further clarification. ${ }^{816}$ Although the 1995 Mekong Agreement states that principles of international law could also be tools for resolving dispute, none of details were specifically included in the Agreement. ${ }^{817}$ Secondly, paragraph 3 of Article 33 of the Convention also mentioned that there is a time limitation for negotiation and other means of dispute resolution. If a dispute cannot be resolved within six months, this dispute should be transferred to "impartial fact finding according to Paragraphs 4-9". ${ }^{818}$ The Mekong water regime should also consider this time limitation when resolving disputes, as this could improve the effectiveness of the dispute settlement process. Moreover, Paragraphs 4-9 in Article 33 of the Convention explain the structure of the Fact-finding Commission and its mechanism of action. Similarly, the Mekong water regime has also developed an international and regional panel of experts ${ }^{819}$ and paid fact-finding visits ${ }^{820}$. But these

\footnotetext{
${ }^{811}$ The 1995 Mekong Agreement (n 138) art 34, 18.C, 24.F.

${ }^{812}$ The 1995 Mekong Agreement (n 138) art 35.

${ }^{813}$ Ibid.

${ }^{814}$ The 1995 Mekong Agreement (n 138) art 35.

${ }^{815}$ The 1997 UNWC (n 169) art 33, Paragraph 2.

${ }^{816}$ Pech (n 284) 70.

${ }^{817}$ Pech (n 284) 67.

${ }^{818}$ The 1997 UNWC (n 169) art 33, Paragraph 3.

${ }^{819}$ MRC, 'Panel of Experts on the Basin Development Plan Phase 2' (Vientiane, 17 August 2010-8

October 2010) <http://www.mrcmekong.org/news-and-events/consultations/panel-of-experts-on-thebasin-development-plan-phase-2/> accessed 2 October 2016.
} 
aspects should also be taken into consideration at the level of legal basis, namely the 1995 Mekong Agreement. In summary, the provisions in the Convention are more explicit than in the Mekong Agreement. The contents of dispute settlement in the Mekong Agreement should be specified more explicitly, and be improved by considering more related aspects.

\subsubsection{Summary and Comments}

Given the extent of the comparison between the 1997 UNWC and the 1995 Mekong Agreement carried out in the preceding section, it would perhaps be best to summarize the points of the Mekong water regime that need to be improved. Beginning with the points that are not mentioned in the 1995 Mekong Agreement or its Procedures, these include groundwater protection, the relationship between different kinds of uses, the control of pollution, alien and new species, marine environment protection, installation, prevention and mitigation of harmful conditions, times of armed conflict, indirect procedures and information vital to national defense or security, non-discrimination, and private remedies. These are followed by several points that have already been included in the 1995 Mekong Agreement, yet are not comprehensive or are not sufficiently explicit and need to be supplemented and improved upon; these consist of equitable and reasonable utilization, the obligation not to cause significant harm, information exchange and notification of planned measures, emergency situations, and dispute settlement.

All in all, although there are several points of the 1995 Mekong Agreement that need to be improved, we must still admit that this Agreement offers a complete framework for trans-boundary water recourse protection and management. The Provisions of the Agreement have already contained main principles and procedures for trans-boundary water resources conservation and management, such as equitable and reasonable utilization, the obligation not to cause significant harm, procedures of notification, and so forth. According to the comparison carried out above, it is readily apparent that the obvious weakness of the 1995 Mekong agreement is the fact that it is overly abstract and lacks explicit wording.

\footnotetext{
${ }^{820}$ MRC, 'Xayaburi Hydropower Project Prior Consultation Process' (Vientiane, 15 December 201022 April 2011) <http://www.mrcmekong.org/news-and-events/consultations/xayaburi-hydropowerproject-prior-consultation-process/> accessed 2 October 2016.
} 
Normally, as a framework for a specific region, the 1995 Mekong Agreement should be more detailed than the general instrument at the international level, i.e. the 1997 UNWC. In fact, however, the provisions of this regional agreement are more general and vague. The reason for this can be traced back to the historical background of the establishment of the Mekong Agreement. In 1995, the Mekong Region had just overcome several regional political and security-related problems, becoming peaceful and stable again. ${ }^{821}$ All the riparian countries wanted to connect with each other by means of international instruments that would maintain a consistently stable situation in the region; ${ }^{822}$ a general and non-restrictive framework for trans-boundary water resource management and protection can be more suitable against this background. Nowadays, however, the effectiveness and efficiency of regional legal instruments is becoming increasingly important, and the Mekong Agreement's drawbacks make this Agreement incapable of effectively supporting the dynamics of the region's development. As the most vital legal basis for the Mekong water regime, this Agreement needs to be improved and adapted to the requirements of the Mekong region's dynamic development.

Above and beyond a comparison with the 1997 UNWC, the legal basis of the Mekong water regime should also make use of some advantageous mechanisms that are crucial to trans-boundary resource conservation and management. These include the mechanisms of public participation and trans-boundary environmental impact assessment. Finally, the enforcement of regional legal instruments at the national level must be seriously considered. In the following section more detail content about these mechanisms and implementation at national level for the improvement of the Mekong water regime has been illustrated.

\subsection{Ways to Improve the International Legal Water Regime of the Mekong River Basin}

To analyze the ways to improve the Mekong water regime, there are several bases that have been expounded upon in former chapters and sections. Not only the comparison between the 1995 Mekong Agreement and the 1997 UNWC laid out above, but also the functional comparison between the Mekong River Commission and the Rhine

\footnotetext{
${ }^{821}$ Browder and Ortolano (n 12) 515-516.

${ }^{822}$ Ibid.
} 
River Commission, as well as the assessment of the Mekong water regime in Chapter two, are capable of providing relevant inspiration.

In accordance with the comparison between the 1995 Mekong Agreement and the 1997 UNWC, we have come to the core conclusion that the 1995 Mekong Agreement, as the only specific legally binding instrument for the Mekong Water regime, is too abstract and vague. The important inspiration derived from the functional comparison is that the institutional functions of the Mekong water regime should not only focus heavily on the regional economic development related to poverty reduction, but more on environmental conservation as well. In addition to this inspiration, the establishment of an institution and of institutional functions should also be strengthened in accordance with the current conditions in the river basin. Moreover, based on the assessment of the 1995 Mekong Agreement and the MRC in Chapter 2, the implementation of the Mekong Agreement and its procedures is also a vital point that extends beyond eliminating the vagueness of the legal basis. Last but not the least, the regime's ineffectiveness and the structural problems outlined in the assessment must be dealt with in order to maximize the benefits provided by the regime.

A further source of inspiration for improvement of the Mekong international legal water regime can be found in efforts related to water resource management. 33 environmental treaties connect the six Mekong countries with each other, and every one of these treaties covers a separate, highly important environmental issue, e.g. biodiversity, climate change, world heritage protection, river basin resource development and economic integration, and so forth. ${ }^{823}$ Moreover, the other related legal instruments and related emerging principles at the international level can also be taken into consideration, ${ }^{824}$ such as the Aarhus Convention, the Espoo Convention, the Biodiversity Convention, and so on.

As we have seen, there are numerous points to be considered as regards improvement of the Mekong international legal water regime. The author would like to express these points from two different perspectives, one being that of the legal basis, and the other that of the regime's institution, namely, the Mekong River Commission. Additionally, the involvement of upstream countries, especially China, is a further

\footnotetext{
${ }^{823}$ Pech (n 284) 24.

${ }^{824}$ The Mekong Research Group (n 765) 11.
} 
crucial aspect for the Mekong water regime's improvement, and will also be discussed in the following.

\subsubsection{Improvements of The Regime's Legal Basis}

As detailed in the analysis in Chapter 2, the legal basis of the Mekong water regime contains several instruments functioning on different levels. The 1995 Mekong Agreement is the main and only specific legally binding instrument for Mekong water resource management and protection. It is the most important legal basis for the Mekong water regime, and a series of procedures have been formulated based on this agreement. From the author's discussion on the necessary improvements to the 1995 Mekong Agreement and its procedures in this section, it will become clear that these improvements, if accomplished, would directly affect the efficiency and effectiveness of the Mekong water regime in the future.

\subsubsection{A More Explicit and Thus More Effective Legal Basis}

As stated in the analysis in Chapter 2, the defining characteristic of the 1995 Mekong Agreement is its abstractness and vagueness. On the one hand, the 1995 Mekong Agreement is only a framework for cooperative efforts working towards sustainable development of the Mekong River basin. On the other hand, however, the 1995 Mekong Agreement as a regional instrument should be more comprehensive and explicit than a general framework at the international level, such as the 1997 UNWC, due to it involves itself more directly with the real problems currently facing the Mekong River basin. In fact, as determined in the comparison between the 1995 Mekong Agreement and the 1997 UNWC, there are several essential points that have not been included in the Mekong Agreement, although it does include specific provisions on the institutional structure of the Mekong River Commission.

The essential points requiring specification, as has been determined based on our analysis, are groundwater protection, the relationship between different kinds of uses, control of pollution, alien and new species, marine environment protection, installation, prevention and mitigation of harmful conditions, times of armed conflict, indirect procedures and information vital to national defense or security, nondiscrimination and private remedies, equitable and reasonable utilization, the obligation not to cause significant harm, information exchange and notification of planned measures, emergency situations, and dispute settlement. 
It has also been determined that the 1995 Mekong Agreement should follow a more ecosystem-oriented approach. ${ }^{825}$ Some provisions for the utilization of shared natural resources in the 1995 Mekong Agreement concentrate mainly on protecting territorial interests, but ecological interests based on ecosystem protection have been underestimated. ${ }^{826}$ This perception was touched upon briefly in the functional comparison in Chapter 3. The conclusion drawn from the functional comparison is that the functions of the MRC based on the work of its Programmes and some procedures focus chiefly on Mekong regional economic development and ignore the importance of ecosystem protection. However, the first paragraph of the Mekong Agreement states that improving cooperation to achieve sustainable development in the Mekong River basin is one of its core missions. This sustainable development consists not only of economic development, but also social and environmental sustainable development. Therefore, considering improvements to the legal basis and adding more ecology-oriented contents to the Mekong water regime could be a way to enhance its effectiveness as regards environmental protection and ecosystem sustainable development.

The attempt to implement a legal basis is an important test to check whether this legal basis is effective or not. The functional comparison we carried out made it clear that the implementation of the Mekong Agreement and its procedures is not sufficiently effective. We concluded that one of the main reasons for this situation is that most of the relevant procedures and documents governing the different functions of the MRC are non-legally binding. However, according to the analysis of hard and soft law for the trans-boundary water recourse protection and management in the chapter 2 to this dissertation, formulating "hard" instruments for different functions of the Mekong international legal water regime could cause problems as well; for instance, overly strict procedures would make member countries wary to join. In this context, the author suggests that the Mekong water regime initially focus more on the institutional functions themselves. Despite the non-legally binding nature of these functions' procedures, as long as they are truly capable of meeting the needs that are most urgent

\footnotetext{
${ }^{825}$ Pech (n 284) 74; Owen McIntyre, 'The Protection of Freshwater Ecosystems Revisited: Towards a Common Understanding of the 'Ecosystems Approach' to the Protection of Transboundary Water Resources' (2014) 23/1 RECIEL 88, 95.

${ }^{826}$ Pech (n 284) 74.
} 
in the region, this function can more or less be implemented. For example, although the document of the Fishery Programme is a non-legally binding instrument, the MRC can still rely on this Programme to enhance people's related awareness, skills and capacities in this context. ${ }^{827}$ No matter how small the accomplishment of a non-legally binding procedure, it is still a vital method for the Mekong international legal water regime to enhance its real impact on the Mekong River basin. Therefore, when formulating the procedures of the MRC's functions, the MRC should engage in careful consideration of the regional realities to analyze details of the functions, including the local economy, climate, geographical characteristics, and so on, and make sure that these procedures truly reflect regional needs. Based on the MRC's efforts, the implementation of the 1995 Mekong Agreement can also be enhanced to some extent.

\subsubsection{The Transboundary Environmental Impact Assessment}

\subsection{Brief Introduction to the EIA}

Carrying out an environmental impact assessment (EIA) means that "the impact of (potentially) environmentally harmful projects should be analyzed before the authorization of the project is granted, in order to be able to take a decision in view of all impacts of a project". ${ }^{828}$ Therefore, the EIA can also be treated as a derivative of the precautionary principle in environmental law. ${ }^{829}$ Additionally, the EIA can also be associated with the obligation of states to notify and consult other States before beginning a project that could have a potentially harmful impact on the environment in other States. ${ }^{830}$ The EIA plays an important role in dealing with different obligations between neighboring states based on this consideration of potentially adverse trans-boundary impacts. ${ }^{831}$ The EIA process guarantees that such

\footnotetext{
${ }^{827}$ MRC, 'Fisheries Programme' (Official Website of the MRC)

$<$ http://mrcmekong.mrcdev.info/about-mrc/programmes/fisheries-programme/> accessed 2 October 2016.

${ }^{828}$ Astrid Epiney, 'Environmental Impact Assessment', Max Planck Encyclopedia of Public International Law (Fall edn 2009), Paragraph 1

<http://opil.ouplaw.com/view/10.1093/law:epil/9780199231690/law-9780199231690-

e1581?rskey=MI8OFW\&result=1\&prd=EPIL> accessed 29 September 2016.

${ }^{829}$ Ibid.

${ }^{830}$ Ibid.

${ }^{831}$ Ibid.
} 
considerations are integrated in any decision-making process. ${ }^{832}$ Hence, the EIA provides helpful measures for the mitigation of harmful environmental effects, as well as alternatives that have a less adverse effect on the environment. ${ }^{833}$ The EIA is thus a tool decision-makers use to evaluate a project's environmental impact before a decision is taken, and it must also to be reflected in the final decision of any project. ${ }^{834}$ The EIA is a process originally deriving from the 1969 National Environmental Policy Act of the United States. The first appearance of an EIA at the international level was after the UN Conference on the Human Environment in 1972. The Stockholm Declaration did not explicitly require an EIA, but principles 14 and 15 of the Declaration imply the rationale for an EIA and mention "a tool for combining development and environment needs" and "a view to avoid adverse environmental effects and obtain maximum social, economic and environmental benefits". ${ }^{835}$ Nowadays, the EIA is often included in international legal systems, especially in those of the EU. ${ }^{836}$ There are three main legally binding instruments aimed at establishing an EIA in the EU Legal System: EC Directive 85/337 on the Assessment of the Effects of Certain Public and Private Projects on the Environment, EC Directive 2001/42 on the Environment Assessment of the Effects of Certain Plans and Programs on the Environment, and the famous Espoo Convention for Trans-boundary EIA ${ }^{837}$ In addition to the member countries of the UNECE, there are also 44 countries that have joined the Espoo Convention. The provisions of the Espoo Convention have also been taken into account by many countries in Africa, Asia, and Latin America. ${ }^{838}$ At the international level, there are also some non-legally binding instruments for the EIA. ${ }^{839}$ One example is principle 5 of the United Nations Environment Programme (UNEP), which is entitled "Conservation and Harmonious Utilization of Natural Resources Shared by Two or More States". ${ }^{840}$ The UNGA Res 34/186 in 1979 adopted

\footnotetext{
${ }^{832}$ Epiney (n 828) Paragraph 2.

${ }^{833}$ Ibid.

${ }^{834}$ Ibid.

${ }^{835}$ Epiney (n 828) Paragraph 3.

${ }^{836}$ Epiney (n 828) Paragraph 4.

${ }^{837}$ Ibid.

${ }^{838}$ Ibid.

${ }^{839}$ Epiney (n 828) Paragraph 39.

${ }^{840}$ Epiney (n 828) Paragraph 40.
} 
and confirmed Principle 5 of the UNEP. ${ }^{841}$ The UNEP Goals and Principles of EIA in 1987 provided objectives relevant to an EIA and minimum standards for implementing one. ${ }^{842}$ Principle 17 of the Rio Declaration confirms the necessity of having an EIA..$^{843}$ Moreover, the ILC's Draft Articles on Prevention of Transboundary Harm from Hazardous Activities adopted Principle 17 of Rio Declaration in $2001 .^{844}$ Many other non-legally binding instruments can also be associated with the EIA, and their existence supports the establishment and enhancement of EIAs. ${ }^{845}$

\subsection{The EIA and the Mekong Water Regime}

As we have seen above, it is obvious EIAs has always been associated with shared resources and their utilization and conservation. As it concerns the Mekong water regime, the core element is shared water resource protection and management. Moreover, proposed hydropower development and other measures on the mainstream and tributaries of the Mekong River have already affected the river basin significantly, ${ }^{846}$ and all of the riparian countries realize that they must take measures to prevent, avoid or mitigate the related impacts. Therefore, it is necessary and also rational for the Mekong water regime to include an EIA as a crucial tool for the transboundary water resources protection and management. Besides these two former reasons, the member countries of the 1995 Mekong Agreement are required to notify, hold prior consultation or agreement to discuss the transboundary impacts of their planned measures ${ }^{847}$ EIAs can be an important basis for this process, and can also play a key role in situations where disputes occur between neighboring countries based on their planned measures.

There are already plenty of practices of EIA in the Mekong water regime. The Mekong River Commission has carried out a series of pilot studies and programs to

\footnotetext{
${ }^{841}$ Epiney (n 828) Paragraph 41.

${ }^{842}$ Epiney (n 828) Paragraph 44.

${ }^{843}$ Epiney (n 828) Paragraph 45.

${ }^{844}$ Ibid.

${ }^{845}$ Epiney (n 828) Paragraph 46.

${ }^{846}$ MRC, 'Transboundary EIA' (Official Website of the MRC) <http://www.mrcmekong.org/aboutmrc/completion-of-strategic-cycle-2011-2015/environment-programme/transboundary-eia/> accessed 2 October 2016.

${ }^{847}$ Ibid.
} 
improve member countries' capacities for transboundary EIAs. ${ }^{848}$ In order to support the Procedures for Notification Prior Consultation and Agreement (PNPCA), the MRC has also developed a Framework for Transboundary EIAs (TbEIAs). ${ }^{849}$ Another important practice related to EIAs is the Strategic Environmental Assessment of the 12 Hydropower Projects on the Mainstream of the Mekong River, which deals with the tranboundary impacts of proposed mainstream development in the lower Mekong basin. ${ }^{850}$ Although the SEA has not been officially approved by the MRC, it still offers a wealth of important regional information to the PNPCA. ${ }^{851852}$ All in all, these practices improve the Member Countries' understanding of the dispute settlement process in transboundary environmental matters and comprehensive considerations for sustainable hydropower development. ${ }^{853}$ Additionally, the related dialogue, exchange of information, and national capacity building for EIAs has also been enhanced by the Member Countries. ${ }^{854}$

Although there are already several EIA-related practices in the Mekong water regime, the current situation of EIA is still not comprehensive, stable and systematic. The framework for TbEIAs is also still in the draft stage, and needs to be further strengthened and confirmed. ${ }^{855}$ The author suggests the Mekong water regime improves its EIA based on the Espoo Convention. One reason for choosing the Espoo convention is that it is the most famous and legally binding international instrument for tranboundary EIA, and is open to countries outside of the framework of the UNECE. Another reason is the relationship between the MRC and European donors; for example, some hydropower development projects have been established based on

\footnotetext{
${ }^{848}$ Ibid.

${ }^{849}$ Ibid.

${ }^{850}$ Grumbine, Dore and Xu (n 440) 94.

${ }^{851}$ MRC, 'Strategic Environmental Assessment of Mainstream Dams' (Official Website of the MRC)

$<$ http://www.mrcmekong.org/about-mrc/completion-of-strategic-cycle-2011-2015/initiative-on-

sustainable-hydropower/strategic-environmental-assessment-of-mainstream-dams/> accessed 2

October 2016.

${ }^{852}$ MRC, 'Transboundary EIA' (Official Website of the MRC) <http://www.mrcmekong.org/aboutmrc/completion-of-strategic-cycle-2011-2015/environment-programme/transboundary-eia/> accessed 2 October 2016.

${ }^{853}$ Ibid.

${ }^{854}$ Ibid.

${ }^{855}$ Ibid.
} 
support from European donor countries, such as Germany and Sweden. These donor countries can provide member countries of the Mekong water regime with suggestions for establishing transboundary EIAs in projects based on the Espoo Convention. Considering the fact that a very strict and legally binding instrument would be very difficult to implement by the member countries in the Mekong River basin, the author also suggests that the improvement of the EIA not be to make it highly strict right from the beginning. Otherwise, the Member Countries will be reluctant to adopt the instrument, or adopt it but not be able or willing to implement it efficiently. As stated, the best choice would be for the MRC to establish a non-legally binding guideline or a specific Programme for conducting the TbEIA based on the Espoo Convention.

\subsubsection{Public Participation}

\subsection{Brief Introduction to Public Participation}

In matters related to the environmental protection, public participation can be understood as the right and opportunity of members of the public to participate in environment-related decision-making processes ${ }^{856}$ It reflects the public's contribution to and influence on decisions that stand to improve the implementation of environmental laws. ${ }^{857}$ Public participation is a broad concept that contains various forms, situations, institutions, and also the implementation of environmental policies and laws in monitoring and supervision, or in the enforcement of environment-related laws ${ }^{858}$ One very typical form of public participation is the procedure to apply for a permit for a new installation activity that might cause an impact on the environment. ${ }^{859}$ This case can also be seen as a connection between public participation and environmental impact assessment. Additionally, according to the context and discourse of international law and policy, the understanding of public participation in environmental matters is closely connected with access to related

\footnotetext{
${ }^{856}$ Jonas Ebbesson, 'Public Participation in Environmental Matters', Max Planck Encyclopedia of Public International Law (Fall edn 2009), Paragraph 1 <http://opil.ouplaw.com/view/10.1093/law:epil/9780199231690/law-9780199231690e1769?rskey=VdmStq\&result=1\&prd=EPIL > accessed 29 September 2016. ${ }^{857}$ Ibid. 
information and justice in environmental matters. ${ }^{860} \mathrm{In}$ summary, public participation is an important basis for enhancing "environmental democracy" and can also be considered a crucial component of States" "internal affairs". ${ }^{861}$

After the appearance of "environmental law" in the 1960s, public participation in environmental contexts also became a popular issue to be discussed in legal environmental discourse. Especially the Stockholm Conference was a starting point for public participation at the international level. ${ }^{862}$ Then, in 1982, Principle 23 of the UN World Charter for Nature emphasized the importance of public participation, and pointed out that the public participation is linked to access to relevant decisionmaking and environmental justice. ${ }^{863}$ Later, in 1992, Principle 10 of the Rio Declaration again expressed this issue ${ }^{864}$ However, Principle 10 cannot be treated as general international law, but in fact has influenced national as well as international law. ${ }^{865}$ The Aarhus Convention improved the perception embodied in Principle 10 of the Rio Declaration in 1998, and offered related standards and criteria for its implementation. ${ }^{866}$ Beyond these, there are numerous other regional and global environmental agreements related to public participation. For instance, to some extent, the attention of international human rights law has also been drawn to public participation in environmental matters. ${ }^{867}$ Furthermore, the Article 3 of Nordic Environment Protection Convention in 1974 included a principle of nondiscrimination and equal access in environmental matters, and this principle is also an approach to public participation. ${ }^{868}$ This principle mentions public participation in a

\footnotetext{
${ }^{860}$ Ebbesson (n 856) Paragraph 3.

861 Ibid.

${ }^{862}$ Ebbesson (n 856) Paragraph 4.

${ }^{863}$ The World Charter for Nature [1982] G.A. Res. 37/7, U.N. GAOR, 37th Sess., Supp. No. 51, at 17, U.N. Doc. A/37/51 (1982); ILM 22/455 (1983), Principle 23

<http://www.un.org/documents/ga/res/37/a37r007.htm> accessed 26 October 2016.

${ }^{864}$ Rio Declaration on Environment and Development [1992] UN Doc. A/CONF.151/26 (vol. I); ILM 31/874 (1992), Principle 10

<http://www.unep.org/Documents.Multilingual/Default.asp?DocumentID=78\&ArticleID=1163> accessed 26 October 2016.

${ }^{865}$ Ebbesson (n 856) Paragraph 5.

866 Ibid

${ }^{867}$ Ebbesson (n 856) Paragraph 5-6.

${ }^{868}$ Ebbesson (n 856) Paragraph 7.
} 
broader scope, implying that the existing national standard for public participation "shall be applied also to persons across State borders to the effect that they are granted no less effective opportunities to make use of remedies and procedures for the protection of health and the environment in the State of the harmful activity or installation." ${ }^{869}$ This has been supported by many other regional agreements and policy documents. ${ }^{870}$ Compared with the Aarhus Convention, it is considered to be less ambitious. ${ }^{871}$

\subsection{Public Participation and the Mekong Water Regime}

In the regional regime for Mekong River basin water resources protection and management, public participation is indispensable. The aim of the 1995 Mekong Agreement is to enhance its Member Countries' cooperation in the sustainable development of the Mekong River basin. Public participation is a vital basis for establishing cooperation between Member Countries, ${ }^{872}$ because public participation is a vital tool for internal and external stakeholders to receive access to relevant information and environmental justice. Therefore, to some extent, the MRC's functions also rely on public participation. For example, the thriving hydropower development in the Mekong River requires a comprehensive and high-quality EIA for better environmental consideration of prevention and mitigation of adverse impacts, ${ }^{873}$ and the public participation is a quite crucial step for a comprehensive and effective EIA. Additionally, public participation has also been connected with the human rights that are also important issues in the Mekong River basin's sustainable development. ${ }^{874}$ Last but not the least, the public participation is not only an international concept but

\footnotetext{
${ }^{869}$ Ibid.

${ }^{870}$ Ibid.

${ }^{871}$ Ibid.

${ }^{872}$ Mekong River Commission, 'Public Participation in the Lower Mekong Basin' (2005) Publications of the Mekong River Commission, 2

<http://www.mrcmekong.org/assets/Publications/governance/Public-Participation.pdf $>$ accessed 29 September 2016.

${ }^{873}$ Epiney (n 828) Paragraph 1.

${ }^{874}$ Mekong River Commission, 'Public Participation in the Lower Mekong Basin' (2005) Publications of the Mekong River Commission, 2

<http://www.mrcmekong.org/assets/Publications/governance/Public-Participation.pdf> accessed 29 September 2016.
} 
also plays an important role for national capacity building on water resources protection and management. ${ }^{875}$ In summary, public participation is a crucial basis for many aspects of the Mekong water regime. Enhancing public participation can be an effective and efficient method to improve the Mekong water regime.

As of now, there are already several applications of public participation in the Mekong River basin based on the Mekong water regime. The main conductor for these applications is the institutional organization of the regime, the Mekong River Commission. Since 1995, the MRC has adopted a participatory approach in all of its core and sectorial Programmes. ${ }^{876}$ In late 1996, the Study on Public Participation in the Context of the MRC was initiated. ${ }^{877}$ This study is an important basis for collaboration between internal and external stakeholders with the MRC. ${ }^{878}$ The MRC also drafted MRC Public Participation Strategy in 2003 that provides several insights into the role of the public participation under the MRC governance. ${ }^{879}$ Public participation currently occurs most in the context of the Mekong River's hydropower projects. For example, public participation was an important step in the 2010 Xayaburi Hydropower Project Prior Consultation Process. ${ }^{880}$ Moreover, during the Don Sahong Hydropower Project, even though public involvement was not a requirement of the process, the Member Countries still accepted its importance and agreed to grant national public consultation, or at least a shared meeting based on

\footnotetext{
${ }^{875}$ Ibid.

${ }^{876}$ Ibid.

${ }^{877}$ Prachoom Chomchai, 'Public Participation in Watershed Management in Theory and Practice' Carl

E. Bruch, Public Participation in the Governance of International Freshwater Resources (Tokyo, 1st, United Nations University Press, 2005) 152.

${ }^{878}$ Mekong River Commission, 'Public Participation in the Lower Mekong Basin' (2005) Publications of the Mekong River Commission, 3

<http://www.mrcmekong.org/assets/Publications/governance/Public-Participation.pdf $>$ accessed 29 September 2016.

${ }^{879}$ Chris Sneddon and Coleen Fox, 'Power, Development, and Institutional Change: Participatory Governance in the Lower Mekong Basin’ (2007) 35/12 World Development 2161, 2169.

${ }^{880}$ MRC, 'Xayaburi Hydropower Project Prior Consultation Process' (Vientiane, 15 December 201022 April 2011) <http://www.mrcmekong.org/news-and-events/consultations/xayaburi-hydropowerproject-prior-consultation-process/> accessed 29 September 2016.
} 
national mechanisms and relevant practices. ${ }^{881}$ In May 2015, the MRC established the Guidelines on the Disclosure of Data, Information and Knowledge. The preamble to the Guidelines states that they "detail the categories of data, information and knowledge available to the general public or to interested individuals and groups". ${ }^{882}$ This is an obvious reference to public participation.

From the description above, we can draw the conclusion that the practices of public participation in the Mekong water regime are not comprehensive. There is also no systematic document governing how it is to take place. The public participation process for hydropower projects thus relies only on national mechanisms. ${ }^{883}$ Moreover, the legal basis of the Mekong water regime, the 1995 Mekong Agreement, does not mention the public participation explicitly either. The improvement of this issue is thus urgently necessary. As for the legal basis, the author suggests that the improvement of public participation rely on creating a more effective and comprehensive instrument. The Aarhus Convention can be a very good model for the Mekong water regime to establish an updated instrument. The Aarhus Convention explains the scope of the term "public", elaborates six means for enhancing participation and establishes the minimum rights for members of public with respect to related issues ensured by its parties. ${ }^{884}$ In contrast, these elements have neither been specified in the Mekong water regime's legal basis nor in its institutional procedures or documents of Programmes. The new instruments for public participation must take these points into account. Additionally, according to Article 9 of the Aarhus Convention, public participation in the Mekong water regime should also be extended

\footnotetext{
${ }^{881}$ MRC, 'Don Sahong Hydropower Project' (Vientiane, 15 October 2014-31 January 2015) <http://www.mrcmekong.org/news-and-events/consultations/don-sahong-hydropower-project/> accessed 29 September 2016.

${ }^{882}$ Guidelines on Disclosure of Data, Information and Knowledge [2015] Mekong River Commission, Preamble <http://www.mrcmekong.org/assets/Publications/policies/MRC-Disclosure-GuidelinesRevisedVer-May2015-final.pdf> accessed 02 October 2016.

${ }^{883}$ MRC, 'Don Sahong Hydropower Project' (Vientiane, 15 October 2014-31 January 2015) <http://www.mrcmekong.org/news-and-events/consultations/don-sahong-hydropower-project/> accessed 29 September 2016.

${ }^{884}$ Ebbesson (n 856) Paragraph 19-27.
} 
to allow for access to relevant national court to litigate issues of environmental protection and natural resource exploitation. ${ }^{885}$

\subsubsection{Implementation at the National Level}

According to the assessment in Chapter 2, we were able to determine that, at the national level, the implementation of the 1995 Mekong Agreement and its procedures and work of its Programmes is insufficient. This obvious disadvantage of the Mekong water regime decreases the effectiveness of the MRC and interrupts the connection between the regime's national and international levels.

There are several reasons for this phenomenon. One is that the only legally binding basis of this regime, the 1995 Mekong Agreement, does not contain any specific provisions on the agreement's implementation. Another is that the institutional capacity for the implementation of the Mekong Agreement and its procedures and documents of Programmes is not sufficiently effective. ${ }^{886}$ Although the MRC has formulated a series of documents, the MRC's authority is still not sufficient to promote each procedure and activities of every Programmes. ${ }^{887}$ National Mekong Committees in each of the Member Countries follow in the footsteps of the MRC and also do not have sufficient power to make any breakthroughs. ${ }^{888}$ Only Laos has established its National Mekong Committee by using a legal instrument, the Decree on the Establishment and Operation of the Lao National Mekong Committee, in 1999. ${ }^{889}$ The third reason is that the national political will for implementation of the Mekong Agreement is not strong enough. ${ }^{890}$ Lastly, the implementation of national water and water-related law is also an element affecting the implementation of the 1995 Mekong Agreement. It has been commented that the national water and waterrelated law of member countries in the Mekong River basin is being used ineffectively. ${ }^{891}$

\footnotetext{
${ }^{885}$ The Mekong Research Group (n 765) 12.

${ }^{886}$ Ibid.

${ }^{887}$ Hirsch, Jensen with Boer, Stephen, Gerald, Lyster (n 251) 113.

${ }^{888}$ Hirsch, Jensen with Boer, Stephen, Gerald, Lyster (n 251) 121.

${ }^{889}$ The Mekong Research Group (n 765) 14.

${ }^{890}$ The Mekong Research Group (n 765) 13.

${ }^{891}$ The Mekong Research Group (n 765) 14.
} 
In fact, in the national environmental and resources law of each of the member countries, although there is also no specific provision for the adoption of the 1995 Mekong Agreement, ${ }^{892}$ the legislative regime at the national level of each of the member countries is sufficient for carrying out the member countries' obligations based on the 1995 Mekong Agreement. ${ }^{893}$ All member countries have announced the establishment of a framework for water governance in their constitutions; these constitutions are also an important basis for involving the public in water resource governance and protection. ${ }^{894}$ The four member countries have also devised a series of national plans for water resource management, and at the same time developed legislation for irrigation, water quality, groundwater, and other related topics. ${ }^{895}$ There are also relative administrative agencies for water resource management in these member countries. ${ }^{896}$

In order to improve the implementation of the 1995 Mekong Agreement at the national level, there are two aspects that must be taken into account. Firstly, the Mekong water regime itself should improve its legal basis. In order to do this, the content relevant to agreement's implementation at the national level must be added into the 1995 Mekong Agreement. Moreover, every Member Country needs to enact specific legislation for adopting the 1995 Mekong Agreement and its relevant procedures. ${ }^{897}$ The relevant legislation also needs to specify how the 1995 Mekong Agreement and relevant provisions would be adopted in particular national jurisdictions based on the role of the National Mekong Committee. ${ }^{898}$ The author suggests that the MRC draft a model law as a basis for legislative enactment in each of the member countries' jurisdictions. ${ }^{899}$ Moreover, the MRC could develop several guidelines for national implementation issues. In the long run, such guidelines could

\footnotetext{
892 The Mekong Research Group (n 765) 14.

${ }^{893}$ Ibid.

${ }^{894}$ The Mekong Research Group (n 765) 17, 24, 33,39.

${ }^{895}$ The Mekong Research Group (n 765) 17-41.

${ }^{896}$ Ibid.

${ }^{897}$ The Mekong Research Group (n 765) 13.

${ }^{898}$ The Mekong Research Group (n 765) 13-14.

${ }^{899}$ The Mekong Research Group (n 765) 14.
} 
be combined together and improve the implementation of the Mekong Agreement and its Procedures at the national level. ${ }^{900}$

\subsubsection{Improvements of the Mekong River Commission}

\subsubsection{Target of Improvement of the MRC}

As we determined in the functional comparison between the Mekong River Commission and the Rhine River Commission, the functions of the MRC focus chiefly on regional economic development and poverty reduction in order to enhance the living conditions of people residing in the Mekong Region. In fact, however, based on the 1995 Mekong Agreement, the aim of the MRC's functions should be to enhance the cooperation between the Member Countries working towards the sustainable development of the Mekong River basin. This aim has set a "triple bottom line" for the Mekong River basin. ${ }^{901}$ This means that the development of the Mekong should contain three aspects: social, economic and environmental development. ${ }^{902}$ The aim treats each of these three aspects as interdependent elements, and in that sense differs from the view that economic development requires the sacrifice of social and environmental development. ${ }^{903}$ The functions of the MRC thus need to be improved in order to better live up to the standard of this "triple bottom line".

In order to achieve this goal, several avenues must be taken into consideration by the MRC. Firstly, the MRC should focus on improving the well-being of the river basin's ecosystem, the well-being of the relevant communities' livelihood, and also the wellbeing of the public good. ${ }^{904}$ Secondly, the MRC should use its knowledge to ensure the "triple bottom line" and to influence decision-making on important development projects in the Mekong River basin..$^{905}$ The MRC should objectively offer the social, environmental and economic implications for projects related to the Mekong river basin, and ensure that the river basin development outcomes are livelihood-oriented and sustainable. ${ }^{906}$ Moreover, the MRC must also provide suggestions to alternative

\footnotetext{
900 Ibid.

${ }^{901}$ Hirsch, Jensen with Boer, Stephen, Gerald, Lyster (n 251) 112.

902 Ibid.

903 Ibid.

${ }^{904}$ Hirsch, Jensen with Boer, Stephen, Gerald, Lyster (n 251) 129.

${ }^{905}$ Hirsch, Jensen with Boer, Stephen, Gerald, Lyster (n 251) 129-130.

${ }^{906}$ Hirsch, Jensen with Boer, Stephen, Gerald, Lyster (n 251) 130.
} 
sustainable development solutions. ${ }^{907}$ Therefore, the MRC should focus especially on economically driven investments in order to ensure that these investments have already taken environmental and social well-being into account. ${ }^{908}$ Thirdly, the MRC should produce scientific knowledge vital for assisting relevant governments, international institutions, project developers and other stakeholders in making decisions based on "triple bottom line" theory ${ }^{909}$ Fourthly, the MRC should make efforts to transform its regulations into "harder law" based on agreed rules and procedures. ${ }^{910}$ Although soft law is capable of influencing Mekong River basin water resource management and protection, it is not sufficient for meeting the reality of the issues facing the Mekong River basin. Therefore, in order to enhance the effectiveness of the MRC's functions, the only way to move forward is by making its regulations harder. There are several preconditions for this; one is that Member Countries accept limitations on their national sovereignty, and another is that the MRC be more proactive "in fulfilling its mandate for trans-boundary water governance and in defining its organizational role". ${ }^{911}$ Fifthly, the MRC's development planning should take place on a basin-wide scale that encompasses not only the mainstream of the Mekong river but also the development of tributaries of the Mekong River. ${ }^{912}$

\subsubsection{Recommendations for Enhancing the Role of the MRC}

According to the former section, which explicitly expressed the target of improvement for the MRC, a series of recommendations will be provided in the following.

4.2.2.2.1. Combining the Improvement of the Legal Basis of the Mekong Water Regime with the Improvement of the MRC

First of all, the MRC needs to combine improvement of its role with improvement of the legal basis of the Mekong water regime. The author has already discussed the improvement of the Mekong water regime's legal basis, which can be summarized as

\footnotetext{
${ }^{907}$ Hirsch, Jensen with Boer, Stephen, Gerald, Lyster (n 251) 130.

908 Ibid.

${ }^{909}$ Ibid.

${ }^{910}$ Ibid.

${ }^{911}$ Hirsch, Jensen with Boer, Stephen, Gerald, Lyster (n 251) 131.

${ }^{912}$ Hirsch, Jensen with Boer, Stephen, Gerald, Lyster (n 251) 130.
} 
follows: Based on the comparison between the 1995 Mekong Agreement and the 1997 UNWC, a series of points of the 1995 Mekong Agreement and its procedures should be specified and supplemented. ${ }^{913}$ Transboundary environmental impact assessment and public participation have also been mentioned. ${ }^{914}$ Another vital point is the enactment of national legislation for water resource management to implement the 1995 Mekong Agreement's provisions. ${ }^{915}$ As a management organization of the 1995 Mekong Agreement, the MRC should take the responsibility to realize the 1995 Mekong Agreement's original intentions. For example, in order to enhance the role of the transboundary EIA, at the very beginning, the MRC could first establish some relevant non-legally binding procedures or guidelines. Afterwards, these efforts, to some extent, will have elaborated the importance of the transboundary EIA and provided a suitable and effective basis for enhancing the legal instruments at higher levels.

\subsection{Improving the Connection of the MRC with the National Level}

The National Mekong Committee (NMC) plays an important role in connecting functions of the MRC with water resources governance at the national level. Therefore, in order to ensure the NMC's functions and clarify its role as a "bridge" for national and transboundary water resources governance, the MRC should review the NMC's role and mandates. ${ }^{916}$ The NMC itself should also elaborate policies to combine national water related legislation and policies with the 1995 Mekong Agreement, related procedures, guidelines and policies. Moreover, the NMC-related national governmental ministers should formulate draft legislation for public consultation. ${ }^{917}$ This draft legislation should be introduced into national legislatures, and also refer to the need for implementation of the MRC's policies and procedures. ${ }^{918}$ One suggestion is to have a specific capacity-building program for agencies that manage water resources in participating jurisdictions. ${ }^{919}$ This program is used for

\footnotetext{
${ }^{913}$ See "4.2.1. Improvement of the Legal basis"

914 Ibid.

915 Ibid.

${ }^{916}$ Hirsch, Jensen with Boer, Stephen, Gerald, Lyster (n 251) 132.

${ }^{917}$ Ibid.

${ }^{918}$ Hirsch, Jensen with Boer, Stephen, Gerald, Lyster (n 251) 132.

${ }^{919}$ Ibid.
} 
informing these agencies of their responsibilities to legislate, and enhancing their ability to implement the legislation. ${ }^{920}$ Additionally, a body that can coordinate all the work of all related government agencies is necessary at the national level. It should also consider transboundary water issues and regional developments by involving environmental and social elements. ${ }^{921}$ Furthermore, prosecutors and judicial officers from the participating jurisdictions should take part in the capacity-building programs in order to facilitate their implementation and enforcement of related legislation. ${ }^{922}$ This could strengthen relevant civil and criminal compliance and enforcement processes. $^{923}$

\subsubsection{Applying the MRC's Knowledge and Advice in a More Effective Way}

The MRC's knowledge and advice is a vital basis for the Mekong River basin development and also for the riparian population's livelihood; this knowledge and advice should be translated into a benefit to the Mekong River's water resource governance. ${ }^{924}$ One recommendation is that a communication strategy be formulated for all of the MRC's programs. This strategy is used to convey the program's modeling, planning, and outputs of river science to governmental decision-makers, other stakeholders, and civil society of the Mekong River basin. ${ }^{925}$ This strategy will provide a platform for communication between stakeholders and decision-makers, and at the same time enhance access to environmental information. ${ }^{926}$ Especially, it can transform the MRC's knowledge and advice into ways to meet stakeholders' demands. ${ }^{927}$ Therefore, to some extent, this strategy could also promote the development of public participation, and offer a good basis for transboundary EIA. Furthermore, the MRC should also enhance the quality of the related riparian staff base, whose duty is to provide "independent and objective knowledge and advice" of

\footnotetext{
${ }^{920}$ Ibid.

${ }^{921}$ Hirsch, Jensen with Boer, Stephen, Gerald, Lyster (n 251) 133.

922 Ibid.

923 Ibid.

${ }^{924}$ Ibid.

${ }^{925}$ Ibid.

${ }^{926}$ Ibid.

${ }^{927}$ Hirsch, Jensen with Boer, Stephen, Gerald, Lyster (n 251) 133.
} 
the Mekong River and related issues. ${ }^{928}$ Additionally, the MRC staff (i.e. specialists in Programme areas) should join in decision-making process. ${ }^{929}$

Better application of the MRC's knowledge and advice within each member country also requires commitment from greater constituency, government and civil society. ${ }^{930}$ Hence, it is necessary for governments, donors and the MRC Secretariat to cooperate with each other, and to promote broader and deeper MRC engagement in transboundary natural resource management through related national agencies. ${ }^{931}$ The NMC plays an important role in these cases and is required to work with several stakeholders. ${ }^{932}$ Given this background, a separate strategy should be provided for each of the member countries, the contents of which should be in accordance with the analysis of the potential for the broadening of MRC management.

When facing mega-projects and controversial projects, the MRC should be more proactive. ${ }^{933}$ The MRC should proactively apply its knowledge and convey its advice based on its involvement in the decision-making processes of those projects that could have a significant impact on the Mekong River basin and thus have a high potential for causing conflict. ${ }^{934}$ On the one hand, the MRC can provide suitable mitigation strategies for existing projects. ${ }^{935}$ On the other, the MRC can also use its knowledge and advice to ensure that the "triple bottom line" has been utilized as a basis for designing and recommending new projects, or to provide suitable alternatives when the "triple bottom line" cannot be met. ${ }^{936}$

\subsection{Following the Basic IWRM Principle of Stakeholder and Community} Involvement

The basic IWRM principle of stakeholder and community involvement states that "water development and management should be based on a participatory approach,

\footnotetext{
${ }^{928}$ Ibid.

${ }^{929}$ Hirsch, Jensen with Boer, Stephen, Gerald, Lyster (n 251) 133-34.

${ }^{930}$ Hirsch, Jensen with Boer, Stephen, Gerald, Lyster (n 251) 134.

${ }^{931}$ Ibid.

${ }^{932}$ Ibid.

${ }^{933}$ Ibid.

${ }^{934}$ Ibid.

${ }^{935}$ Ibid.

${ }^{936}$ Ibid.
} 
involving users, planners and policy-makers at all levels." 937 This principle raises awareness of water issues among policy-makers and the general public, and at the same time decentralizes decision-making to the lowest appropriate level. ${ }^{938}$ It is a means of achieving long-term consensus, and requires the government's cooperation to ensure participation of all stakeholders, especially the vulnerable groups. ${ }^{939}$ As a management institution for the Mekong River water resources management and protection, the MRC needs to be more "service-oriented and demand-driven". ${ }^{940}$ Hence, the MRC should follow the IWRM principle of participatory approach and formulate a specific strategy that is flexible, diverse and capable of facing the reality of the Mekong River basin. ${ }^{941}$

In order to achieve this goal, the MRC Secretariat should concentrate its knowledge production activities on stakeholder and community issues. ${ }^{942}$ It should become "a more independent information and knowledge center, and a reference point and resource for NMCs in the provision of knowledge, training and capacity-building." ${ }^{943}$ In this sense, the Secretariat acts as a "bridge" to transport the MRC's knowledge to the NMCs, and should make efforts to enhance the capacity building of the NMCs. ${ }^{944}$ These activities of the Secretariat are a foundation for the NMCs' proactive engagement with stakeholders, community groups, civil society and NGOs. ${ }^{945}$ Based on adequate and appropriate knowledge and capacity, the NMCs can better understand the social context, and can therefore respond better to problems in the

\footnotetext{
${ }^{937}$ GWP, ‘2. Participatory approach’ (Official Website of the GWP) < http://www.gwp.org/en/TheChallenge/What-is-IWRM/IWRM-Principles/Participatory-approach/> accessed 2 October 2016.

${ }^{938}$ Mei Xie, 'Integrated Water Resources Management (IWRM)- Introduction to Principles and Practices' (2006) GEF's International Waters Learn Program: the Africa Regional Workshop on
} IWRM, 12 < http://pacificwater.org/userfiles/file/IWRM/Toolboxes/introduction\%20to\%20iwrm/IWRM\%20Introd uction.pdf> accessed 29 September 2016.

${ }^{939}$ GWP (n 937).

${ }^{940}$ Hirsch, Jensen with Boer, Stephen, Gerald, Lyster (n 251) 134-135.

941 Ibid.

${ }^{942}$ Hirsch, Jensen with Boer, Stephen, Gerald, Lyster (n 251) 135.

943 Ibid.

944 Ibid.

945 Ibid. 
development of the Mekong River basin. ${ }^{946}$ The capacity building of the NMCs could also broaden the NMC's constituencies in government line agencies. This is also an important aspect for the NMCs to actively include the civil society. ${ }^{947}$ In summary, the efforts on the part of the MRC Secretariat and the NMCs would establish a strong and effective basis for the MRC to continue with the "triple bottom line" approach. ${ }^{948}$

4.2.2.2. Enhancing the MRC's Relationship with Other Water Development and Governance Arrangements and Related Groups

In addition to the MRC's arrangements on the Mekong River basin, there are also some other existing water development and governance arrangements. These regional arrangements, which are in fact initiatives formulated by the ASEAN, GMS and GWP, were introduced in Chapter 2. First of all, the MRC should delivery its water governance to the GMS as a contribution to the GMS's development goal, and also act as a model for the GMS as it pertains to water resource management and protection. ${ }^{949}$ Secondly, the MRC should engage proactively in the GWP-SEA's arrangements. The MRC should improve its relationship with GWP-SEA and try to institutionalize GWP's IWRM principles in the MRC's Member Countries. ${ }^{950}$ Moreover, the MRC needs to enhance its cooperation with the ASEAN. It should support the ASEAN's Working Group on Water Resource Management. The MRC has an advantage in water management and environmental protection, and should try to press its advantage in the annual round ASEAN and ASEAN+3 Environmental Ministers' meetings by regularly offering advisory input. ${ }^{951}$ Last but not least, the MRC should establish an information-sharing cooperation with the ASEAN Mekong River Basin Cooperation (AMRBC) in order to enhance its ability to provide relevant knowledge. ${ }^{952}$

The relationship between the MRC and regional research and educational bodies, such as universities, is also an aspect that must be taken into consideration.

\footnotetext{
${ }^{946}$ Ibid.

${ }^{947}$ Ibid.

${ }^{948}$ Ibid.

${ }^{949}$ Hirsch, Jensen with Boer, Stephen, Gerald, Lyster (n 251) 136.

${ }^{950}$ Hirsch, Jensen with Boer, Stephen, Gerald, Lyster (n 251) 135.

${ }^{951}$ Hirsch, Jensen with Boer, Stephen, Gerald, Lyster (n 251) 136.

${ }^{952}$ Hirsch, Jensen with Boer, Stephen, Gerald, Lyster (n 251) 136.
} 
Additionally, the MRC must also consider the relationship with NGOs and civil society organizations at the national level. ${ }^{953}$ In order to achieve the goal of improving these relationships, the MRC should be more proactive to the political culture of the ASEAN and MRC's member countries. ${ }^{954}$ Furthermore, the MRC should develop cultural diversification to enhance its influence on the entire Mekong region. ${ }^{955}$ Another aspect improving the MRC's ability to analyze and interpret the societies, and this can be realized by employing more professional specialists for the Mekong region. ${ }^{956}$ Last but not least, establishing a strategy to follow the participatory approach principle of the IWRM is also a meaningful tool for improving these relationships. In accordance with this strategy, the MRC can be more active with the public, and can involve more stakeholders and community issues in its knowledge. ${ }^{957}$

\subsection{An Inspection Panel}

The MRC should build an inspection panel to inspect development proposals based on the experiences of some of its donors, namely the ADB and the World Bank. The aim of this inspection panel is to "to ensure involvement of a broader range of stakeholders and thus to take a wider range of environmental and natural resource issues into account." 958

Several advantages could be found if such an inspection panel was established. At first, an inspection panel in the MRC would enhance the transparency of the development programs, and at the same time the accountability of the MRC's operation would also be improved. ${ }^{959}$ Moreover, this inspection panel would foster the regional public participation on development programs. Public access to and awareness of related information would be enhanced. ${ }^{960}$ Furthermore, this panel is a good tool to educate the public and enhance the public's understanding of the variety and complexity of the development programs in the Mekong River basin. ${ }^{961}$ Lastly,

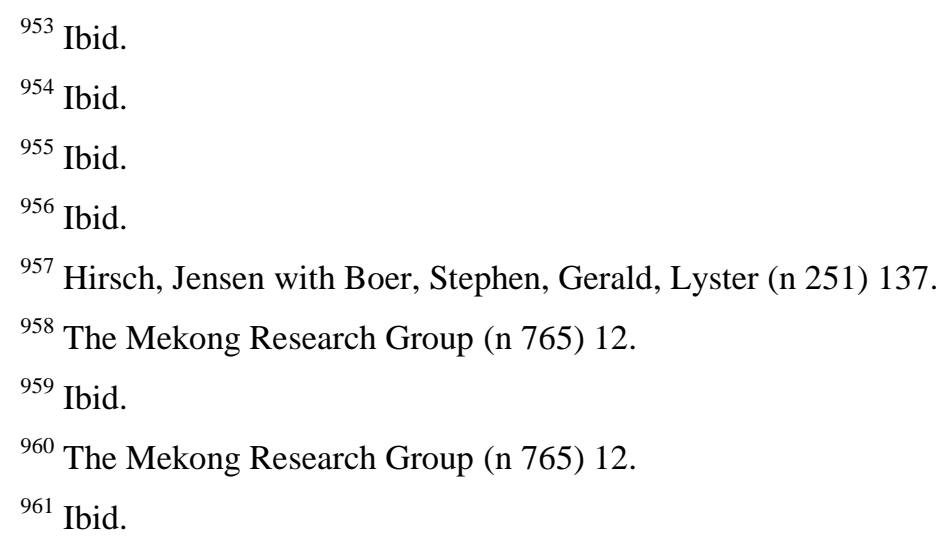


the establishment of an inspection panel would also raise the confidence of donors and other kinds of cooperation partners in the MRC.

\subsubsection{To Enhance Engagement with Donors and NGOs}

\subsection{To Enhance Engagement with Donors}

In order to improve the MRC's engagement with donors, both the MRC and donors should take measures to reach the goal of a consistent coordination. Firstly, the cooperation between the MRC and the donors, and between the donors and the member countries of the MRC should be built based on a more close policy dialogue. ${ }^{962963}$ This means that the dialogue between the donors, the MRC and its members should go beyond technical and managerial issues. ${ }^{964965}$ This is beneficial for donors to better understand the Mekong's regional complexities. Secondly, the dialogue model between the donors and the MRC should be improved. Originally, the Secretariat remained at the center of these dialogues. But this existing mechanism is not sufficient for communication between the donors and the MRC, nor between the donors and MRC's member countries. Dialogue at higher political and bureaucratic levels is more effective and efficient for solving problems between the donors, the MRC and its member countries. ${ }^{966}$ Thirdly, the bilateral programs between the donors and the MRC's member countries should be combined with donors' assistance to MRC, which would be able to mitigate conflicts based on tributary development programs. ${ }^{967}$ Fourthly, donors should provide feasible, useful suggestions and information to the MRC, with the aim of enhancing the work of the MRC and, particular, making improvements to its Secretariat. ${ }^{968}$ Fifthly, a "lead donor" is necessary for the donors. The lead donor would play a role as representative of all donors and coordinator for the cooperation between donors and the MRC. ${ }^{96970}$ Sixthly,

\footnotetext{
${ }^{962}$ Hirsch, Jensen with Boer, Stephen, Gerald, Lyster (n 251) 138.

${ }^{963}$ Hirsch, Jensen with Boer, Stephen, Gerald, Lyster (n 251) 35.

${ }^{964}$ Hirsch, Jensen with Boer, Stephen, Gerald, Lyster (n 251) 138.

${ }^{965}$ Hirsch, Jensen with Boer, Stephen, Gerald, Lyster (n 251) 35.

${ }^{966}$ Hirsch, Jensen with Boer, Stephen, Gerald, Lyster (n 251) 39.

${ }^{967}$ Hirsch, Jensen with Boer, Stephen, Gerald, Lyster (n 251) 36.

${ }^{968}$ Hirsch, Jensen with Boer, Stephen, Gerald, Lyster (n 251) 37.

${ }^{969}$ Hirsch, Jensen with Boer, Stephen, Gerald, Lyster (n 251) 139.

${ }^{970}$ Hirsch, Jensen with Boer, Stephen, Gerald, Lyster (n 251) 38.
} 
the MRC needs to clarify its strategies and objectives, which would avoid problems brought about by different donor interpretations and disagreements. ${ }^{971}$ This would also be beneficial for long-term financial management and save a lot of transaction time between donors and the MRC, as well as among donors. ${ }^{972}$ Seventhly, the MRC and the donors should cooperate together to foster the development of other Mekong stakeholders and water governance arrangements, such as civil society groups, regional NGOs, and academic research on relevant topics. ${ }^{973}$ Last but not the least, the MRC should be proactive in supporting and participating in other donors' Mekong River-related programs, especially investment programs, such as the GMS program raised by the ADB. Some of these programs can involve China reasonably, and at the same time enhance the efficiency and transparency of cooperative efforts in accordance with these programs. ${ }^{974975}$

\subsection{To Enhance Engagement with NGOs}

There are many international and national NGOs that engage with the MRC. ${ }^{976}$ Two of the most famous NGOs of them are the WWF and the IUCN, which has observer status and can attend MRC Council and Joint Committee meetings. ${ }^{977}$ The engagement with NGOs is important for improvement of the MRC, especially for enhancing stakeholder involvement, due to the close relationship between NGOs and the civil society and public interests. But in fact, the MRC's engagement with NGOs is very reactive. It gives the NGOs a feeling that the MRC is a "distant" organization reluctant to cooperate with them. ${ }^{978}$

\footnotetext{
${ }^{971}$ Hirsch, Jensen with Boer, Stephen, Gerald, Lyster (n 251) 40.

972 ibid.

${ }^{973}$ Hirsch, Jensen with Boer, Stephen, Gerald, Lyster (n 251) 41.

${ }^{974}$ Hirsch, Jensen with Boer, Stephen, Gerald, Lyster (n 251) 140.

${ }^{975}$ Hirsch, Jensen with Boer, Stephen, Gerald, Lyster (n 251) 43.

${ }^{976}$ Ellen Bruzelius Backer, 'The Mekong River Commission: Does It Work, and How Does the Mekong Basin's Geography Influence Its Effectiveness?' (2007) 4 Südostasien aktuell: journal of current Southeast Asian affairs 31, 51.

${ }^{977}$ MRC, 'Development Partners \& Partner Organisations' (Official Website of the MRC) <http://www.mrcmekong.org/about-mrc/development-partners-and-partner-organisations/> accessed 2 October 2016.

${ }^{978}$ Hirsch, Jensen with Boer, Stephen, Gerald, Lyster (n 251) 51.
} 
According to this current situation, there are several suggestions for both the MRC and the NGOs engaged with the MRC. These suggestions can enhance the engagement between the MRC and related NGOs. Improving the capacity of the NGOs is the first step. The NGOs should be more competent and better equipped at their positions for achieving public interests. ${ }^{979980}$ The second step is that the MRC should offer more access of river science to non-specialists, which include NGOs. ${ }^{981982}$ Moreover, more proactive work on the part of NGOs is encouraged based on collaborative dialogue and advocacy work with the MRC, the NMCs, and also donors. ${ }^{983}$ Therefore, the MRC should also be proactive in contacting the NGOs. Furthermore, any cooperation between the MRC and the NGOs should pay more attention to the predicament of the Mekong River and its people, and attract more international notice, because, to some extent, improvement of this predicament is not only a regional issue but also a global responsibility. ${ }^{984}$ Lastly, during cooperation with the NGOs, the MRC should accept their variety. Some NGOs tend to be very political, and some are more soft and complementary. ${ }^{985986}$ Therefore, the form of the cooperation between the NGOs and the MRC should also be more flexible. This is a more convenient basis to establish effective and efficient cooperation between them.

\subsubsection{Involvement of China}

There are six countries in the Mekong River basin, but not all of them are member countries of the 1995 Mekong Agreement and the MRC. The two upper-stream countries, Burma and China, which also hold vital positions in the Mekong River basin, are still dialogue partners to the Mekong water regime. Especially China, which is a super country and one of the biggest economic bodies in the world, not to mention where the Mekong River originates. Its actions on the upstream of the Mekong River could have direct or indirect impact on the other riparian countries and can exert

\footnotetext{
${ }^{979}$ Hirsch, Jensen with Boer, Stephen, Gerald, Lyster (n 251) 140.

${ }^{980}$ Hirsch, Jensen with Boer, Stephen, Gerald, Lyster (n 251) 44.

${ }^{981}$ Hirsch, Jensen with Boer, Stephen, Gerald, Lyster (n 251) 141.

${ }^{982}$ Hirsch, Jensen with Boer, Stephen, Gerald, Lyster (n 251) 45.

${ }^{983}$ Hirsch, Jensen with Boer, Stephen, Gerald, Lyster (n 251) 46.

${ }^{984}$ Hirsch, Jensen with Boer, Stephen, Gerald, Lyster (n 251) 47.

${ }^{985}$ Hirsch, Jensen with Boer, Stephen, Gerald, Lyster (n 251) 141.

${ }^{986}$ Hirsch, Jensen with Boer, Stephen, Gerald, Lyster (n 251) 48.
} 
relevant influences on the Mekong River basin. ${ }^{987}$ Although, as a dialogue partner, China has already established stable cooperation with the Mekong international legal water regime, there are still a series of reasons for China to hesitate over involvement in the Mekong water regime. These reasons were introduced in Chapter 2. A fundamental requirement for an effective and efficient international regime is that it includes all significant states. ${ }^{988}$ Therefore, the involvement of China would also be a substantial way to improve of the Mekong water regime.

\subsubsection{Reasons to Involve China}

There are several reasons to involve China in the Mekong water regime, and the MRC should play a proactive role in welcoming and encouraging China into this governance framework for the Mekong River basin. ${ }^{989}$

First of all, a crucial reason already mentioned is that the involvement of China could make the Mekong water regime more comprehensive; as a powerful upstream country, China's participation would enhance the Mekong water regime's effectiveness and efficiency. A further reason is that Chinese participation would strengthen the MRC's ability to be an effective IWRM institution due to the fact that Chinese participation could bring more effective and detailed consultation between all Mekong Countries. ${ }^{990}$ Moreover, the mutual trust, confidence and understanding of issues that refer to water-related Lancang-Mekong development would be strengthened by involving China, and the related decision-making process could also therefore be improved. ${ }^{991}$ Furthermore, Chinese involvement could also enhance dispute settlement under the Framework of the Mekong water regime, namely the MRC's dispute resolution. ${ }^{992}$ Last but not the least, according to involvement of China, the MRC could gain more information and experience with water resources management and protection, thereby boosting the MRC's role as a knowledge center for the Mekong River basin. ${ }^{993}$

\footnotetext{
${ }^{987}$ Boer, Hirsch, Johns, Saul and Scurrah (n 11) 16-17.

${ }^{988}$ Backer (n 976) 46.

${ }^{989}$ Hirsch, Jensen with Boer, Stephen, Gerald, Lyster (n 251) 137.

990 ibid.

991 ibid.

992 ibid.

${ }^{993}$ Hirsch, Jensen with Boer, Stephen, Gerald, Lyster (n 251) 137.
} 
From China's viewpoint, although there are some disadvantages due to its involvement in the Mekong water regime, the forthcoming advantages are also politically, economically and ecologically important for China. Firstly, involvement of China can enhance the cooperation between China and other Mekong riparian countries, which is important for regional security and political stability. Secondly, this involvement could offer China a good basis for water-related investment cooperation with other Mekong riparian countries. Southwest China is a region remote from Chinese political and economic centers and not very well-developed, and many local people still live in hard conditions similar to populations in other Mekong riparian countries. ${ }^{994}$ Hence, the relationship with neighboring countries plays a very important role for local development. If the involvement of China can be made successful in the future, it will bring southwest China great opportunity for development, especially as it concerns the aspect of economic development. Thirdly, being involved in the Mekong water regime could bring China more experience and methods for environmental protection during water resources exploitation and protection. Water resources exploitation and protection in southwest China is now a very controversial topic. On the one hand, regional economical development relies on the exploitation of the water resources. And on the other hand, related environmental protection is also vital for local population's livelihoods. Given involvement in the Mekong water regime, the "triple bottom line" can also be introduced and applied to water resources management and protection in southwest China, thereby furthering regional sustainable development.

\subsubsection{Potential of China's Involvement}

There are already several existing bases and practices that could generate potential and provide conditions to involve China into the Mekong water regime; these have been analyzed in the following.

\subsection{Potential Based on Existing Cooperation between China and the MRC}

First of all, the Mekong water regime has already established a cooperative relationship with China via its institutional organization, the MRC. In 1996, China became an official dialogue partner of the Mekong water regime, and committed to

\footnotetext{
${ }^{994}$ Albert Park, Sangui Wang, Guobao Wu, 'Regional Poverty Targeting in China' (2002) 86 Journal of Public Economics 123, 129.
} 
increasing its cooperation with other riparian countries, which included sharing related data and information on upstream development. ${ }^{995}$ Then, in 2002, a Memorandum for two monitoring stations in China was signed by China and the MRC, which enhanced the collaborative relationship between China and the Mekong water regime. ${ }^{996}$ More detailed and frequent data exchange between China and the MRC began in June of 2004. In 2006, the MRC Secretariat also started sending China hydrological data from monitoring stations in its Member Countries. ${ }^{997}$ In June of 2010, the official delegation of the MRC and lower stream countries visited dams on the Lancang River, namely the upstream of the Mekong River, after which they convened to discuss future cooperation. China reaffirmed its commitments to continue and improve the cooperation with the MRC in November 2014. ${ }^{998}$

\subsection{Potential Based on Other Related Regional Arrangements}

Besides the direct cooperation between China and the MRC, the other regional waterrelated arrangements could also be the bases for Chinese involvement in the Mekong water regime. These related arrangements include some bilateral and multilateral agreements, such as Upper Mekong Commercial Navigation Agreement, and other initiatives based on some international organizations, such as ASEAN and ADB.

A typical example is the GMS program, established by the ADB in 1992. It is a program to help sub-regional projects in transport, energy, telecommunication, environment, and so forth. ${ }^{999}$ China and all of the other Mekong riparian countries are members of this program. In 2006, the GMS program launched a Core Environmental Program and started to concern itself with the sustainable use of shared natural resources and the environment. Furthermore, the cooperation between the GMS and the MRC has also been developed in many aspects. ${ }^{1000}$ Therefore, according to

\footnotetext{
${ }^{995}$ MRC, 'Upstream Partners' (Official Website of the MRC) < http://www.mrcmekong.org/aboutmrc/upstream-partners/> accessed 2 October 2016.

996 Ibid.

${ }^{997}$ MRC, 'MRC, China and Myanmar cooperate on shared Mekong resources' (Vientiane, 31 August 2006) <http://www.mrcmekong.org/news-and-events/news/mrc-china-and-myanmar-cooperate-onshared-mekong-resources/> accessed 2 October 2016.

998 Ibid.

${ }^{999}$ ADB, 'Overview of the Greater Mekong Subregion' (Official Website of the ADB) <http://www.adb.org/countries/gms/overview> accessed 2 October 2016.

${ }^{1000}$ See Chapter 2, 2.1.3.1.
} 
Chinese membership in the GMS and cooperation between the GMS and the MRC, the GMS could act as a "bridge" for involvement of China in the Mekong water regime.

Another similar example is ASEAN's arrangements on the Mekong water resources and environment protection. Two typical arrangements by ASEAN are the ASEANMekong Basin Development Cooperation (AMBDC) and the ASEAN Working Group on Water Resource Management (AWGWRM). The AMBDC is a framework established in 1996. It aims to promote economic integration, and additionally to promote resource sharing between ASEAN Countries, Mekong countries and China. The AWGWRM is a working group for freshwater management based on the ASEAN's Cooperation on Environment. Although China has not joined this working group, the existing China-ASEAN cooperation relationship includes issues of environmental protection. ${ }^{1001}$ This cooperation could also be a "bridge" for China to be involved in other ASEAN's (which includes most other Mekong countries) freshwater management issues. In summary, the ASEAN can also play a role in enhancing the potential of Chinese involvement in the Mekong water regime.

\subsection{Potential Based on Chinese Proactive Actions on the Mekong River Basin} Furthermore, China is also proactive in building cooperative relationships with Mekong Countries. On 24 March of 2016, the Lancang-Mekong Cooperation Mechanism was established during the Leadership Conference with participation of all six Lancang/Mekong Countries. ${ }^{1002}$ This mechanism is another great endeavor to enhance the cooperation between China and other Mekong River riparian countries after the establishment of the Asian Infrastructure Investment Bank (AIIB). The mechanism follows a 3+5 model, with three cooperation pillars and five priority areas. The three cooperation pillars include political and security issues, economic and

\footnotetext{
1001 ASEAN, 'Overview of ASEAN-China Dialogue Relations' (Official Website of the ASEAN), Socio-Cultural Cooperation Paragraph 33 <http://www.asean.org/?static_post=overview-asean-chinadialogue-relations $>$ accessed 2 October 2016.

${ }^{1002}$ Chinese Ministry of Foreign Affairs, 'Wang Yi elaborated on the five priority areass and three cooperation pillars of the Lancang-Mekong Cooperation Mechanism' Chinese Ministry of Foreign Affairs (Beijing, 12 November 2015) <http://www.fmprc.gov.cn/web/wjdt_674879/wjbxw_674885/t1314376.shtml> accessed 29 September 2016.
} 
sustainable development, and social, cultural and people-to-people exchanges. ${ }^{1003}$ The five priority areas, on the other hand, are connectivity, production capacity, crossborder economic cooperation, water resources, agriculture, and poverty alleviation. ${ }^{1004}$ This Mechanism can be treated as a decisive step for cooperation between China and other Mekong countries. ${ }^{1005}$ It offers a stable and suitable stage for deeper and broader connection in various aspects. ${ }^{1006}$ Based on the cooperation pillar of economic and sustainable development and the three priority areas of water resources, agriculture, and poverty alleviation, the Lancang-Mekong Mechanism provides opportunities and rational pathways for Chinese involvement in Mekong water regime. The establishment of the Lancang-Mekong Mechanism increases the potential of China's involvement in the Mekong water regime.

Another aspect that needs to be considered is the establishment of the AIIB, which was led by the Chinese government. The GMS program of the ADB can, to some extent, promote some aspects of the Mekong River water resources management and protection. Based on the GMS's experiences, the AIIB could also set related programs to foster the Mekong regional sustainable development. It is also a good chance for China to better engage with the Mekong water resources management and protection based on investment actions through the AIIB. All in all, this can be an advantageous condition for Chinese involvement in the Mekong water regime.

4.2.3.2.4. Potential Based on other Related Chinese Experiences on International Watercourse Issues and the UNWC

Besides the proactive actions on the Mekong River basin, China has also established bilateral cooperative efforts with other non-Mekong countries for other international watercourses. China concluded bilateral agreements with Russia, Mongolia, Kazakhstan, North Korea, India and Bangladesh for managing shared rivers and lake basins. ${ }^{100710081009}$ In some of these cases, China is a downstream country, and these

\footnotetext{
${ }^{1003}$ Ibid.

${ }^{1004}$ Ibid.

${ }^{1005}$ Xiaojuan Ping, 'Resources for China-ASEAN January 2016 to March 2016: Chronology of Events'

(2016) 14/2 China: An International Journal 201, 203.

${ }^{1006}$ Ibid.

${ }^{1007}$ Pech (n 284) 25.

${ }^{1008}$ Pech (n 284) 38.
} 
agreements reflect key principles of international water law, such as the principle of reasonable and equitable use, the sharing of benefits, obligation not to significant harm, and sustainable development. ${ }^{1010}$ These experiences are very important for assessing China's practices and its application of international water law. ${ }^{1011}$ In addition, these experiences can also be very suitable models when discussing some aspects of Chinese involvement in the Mekong water regime.

As stated, the experiences mentioned above can also be used to analyze China's practices, and this also applies to its relationship to the UNWC. Specifically, although China refused to sign the UNWC, it has still stated that it reserves "the right to address the question of the non-navigational uses of international watercourses with its neighbors in a fair and reasonable manner and in accordance with relevant international practice and with bilateral watercourse agreements." ${ }^{1012}$ During deliberations on the UNWC, China also expressed its support for many of its norms, especially the principle of equitable and reasonable use. ${ }^{1013}$ This also explains why most Chinese practices on international watercourses respect the approach of the UNWC. ${ }^{1014}$ Nowadays, the UNWC has entered into force and can be applied as a codification of customary international law. Some provisions, due to that they have already recognized as rules of customary international law, can be regarded as binding on non-parties. If a provision from a treaty, such as the 1997 UNWC, wants to be bound to a third party, there are two situations for this: firstly, this provision should already meet all requirements as a rule of customary international law, or secondly, a third party has show consent to this provision. ${ }^{1015}$ China's practice for some international watercourses affairs and attitude in negotiation process of the 1997 UNWC can show its consent to some rules of customary international water law. ${ }^{1016}$ Therefore, we can also infer that China is not a persistent objector to these rules of

\footnotetext{
${ }^{1009}$ Yanmei He, 'China's practice on the non-navigational uses of transboundary waters: transforming diplomacy through rules of international law' (2015) 40 Water International 312, 315.

${ }^{1010}$ Ibid.

${ }^{1011}$ Ibid.

${ }^{1012}$ Ibid.

${ }^{1013}$ Eckstein (n 733) 165.

${ }^{1014}$ Ibid.

${ }^{1015}$ Kaczorowska-Ireland (n 196) 73.

${ }^{1016} \mathrm{He}$ (n 1009) 315.
} 
customary international water law at the their formative stage. ${ }^{1017}$ In conclusion, although China did not sign this Convention, some of its key provisions, which have already been recognized as rules of customary international law, are still binding to China. ${ }^{1018}$ Therefore, these contents of the UNWC could also be utilized as a fundamental guide for Chinese practices on issues of international watercourses, and could offer China a series of rules and processes for dealing with transboundary water issues. On the other hand, one of the MRC members, namely Vietnam as the $35^{\text {th }}$ member country of the UNWC, has signed the UNWC, and this action can connect the Mekong River regime directly with this famous international framework of transboundary watercourse. Hence, as it concerns the involvement of China in the Mekong water regime, the UNWC could also be a suitable tool.

Additionally, China has also participated in numerous multilateral environmental agreements, which include China's commitment to environmental protection in relation to transboundary watercourses protection. These agreements include the Ramsar Wetlands Convention, the Convention on Biodiversity, the Climate Change Convention and the Convention on Desertification, all of which have also been able to supply useful content for furthering Chinese involvement in the Mekong water legal regime. ${ }^{1019}$

\subsubsection{Realizing the Chinese Involvement}

Based on the analysis of the potential of Chinese involvement in the Mekong water regime, the author holds a positive perception on this issue, and hence tries to analyze how Chinese involvement could be realized.

First of all, a very important topic that needs to be discussed is the form of Chinese involvement in the Mekong water regime. According to the existing direct relationship between the Mekong water regime and China, it is apparent that China is merely a dialogue partner to the Mekong water regime. Based on this position as a dialogue partner, China cooperates with other Mekong riparian countries, but its relationship is neither comprehensive nor efficient. Complete involvement of China in the Mekong water regime could be realized in two ways: One would be to allow China to join the 1995 Mekong Agreement, the only specific legally binding

\footnotetext{
${ }^{1017}$ Kaczorowska-Ireland (n 196) 37.

${ }^{1018} \mathrm{He}(\mathrm{n} 1009) 315$.

${ }^{1019}$ Eckstein (n 733) 167.
} 
instrument for the Mekong water regime. The other would be to allow China to obtain the membership in the MRC, the only institution especially geared toward transboundary water resources management and protection.

In order to achieve the complete involvement, firstly, the MRC should establish a cooperative relationship with China, and its members should discuss Chinese membership with the Chinese government on both a collective and individual basis. ${ }^{1020}$ The discussion should include a timetable for organizing Chinese membership. The Secretariat needs to prepare two information papers to cover governance and management issues as well as issues of the negotiation of Chinese membership. ${ }^{1021}$ Secondly, a cooperative framework for managing the flow regimes of existing dams based on the "triple bottom line" theory should be built. ${ }^{1022}$ Moreover, the discussion of Chinese membership is also a chance for the MRC to combine itself with other regional initiatives, ${ }^{1023}$ for instance the ASEAN water related programs, the GMS, and also the new Lancang-Mekong Cooperation Mechanism. Finally, the funding arrangements are also necessary to discuss member states with China and other donors. ${ }^{1024}$

Regardless, we must still consider the current reality of the situation. Twenty years have passed since China became a dialogue partner in 1996, and yet China is still a mere dialogue partner in the Mekong water regime. The reasons why China is reluctant to join this regime have been illustrated in Chapter 2 of this thesis. ${ }^{1025}$ Considering these reasons, the difficulties of a complete involvement of China in the Mekong water regime are obvious. The involvement of China into the Mekong water regime should be a continuing and adjusting process. ${ }^{1026}$ Therefore, the author suggests that Chinese involvement be kept partial. Despite this, suggestions for complete involvement as described above could be kept for some special situations.

\footnotetext{
${ }^{1020}$ Hirsch, Jensen with Boer, Stephen, Gerald, Lyster (n 251) 137.

${ }^{1021}$ Ibid.

${ }^{1022}$ Ibid.

${ }^{1023}$ Hirsch, Jensen with Boer, Stephen, Gerald, Lyster (n 251) 138.

${ }^{1024}$ Ibid.

${ }^{1025}$ See Chapter 2, 2.2.3.2.

${ }^{1026}$ Yuening Long, 'Research on the International Cooperation Legal Mechanism of the Water Resources in the Mekong River Basin' (DPhil thesis, Kunming University of Science and Technology 2014) 109 .
} 
The MRC should allow China to join activities of some sectorial Programmes, such as Programme for sustainable development of hydropower, and irrigation and agriculture Programme. Moreover, the MRC should consider the involvement of China in the aspect of funding arrangements. Furthermore, the bilateral relationship between China and members of the MRC should be kept and developed as well, because this is a vital basis for Chinese involvement in the Mekong water regime. Finally, the MRC should be a "bridge" to connect the Mekong legal water regime with other regional water related initiatives, especially Chinese proactive initiative, such as the recent LancangMekong Cooperation Mechanism.

\subsection{Summary}

This chapter has expressed a very meaningful point of this dissertation, namely the improvement of the Mekong water regime. The analysis laid out in this chapter is beneficial for the future development of the regime, especially for future cooperation between all six riparian countries.

The first part of this chapter introduced the UNWC and analyzed how to use the UNWC as a basis for improvements to the legal basis of the Mekong water regime. The author first provided the historical background of the UNWC and then briefly touched upon the content of the Convention itself; this was a necessary step for the reader to understand the very famous yet also controversial articles in the UNWC. Because of their controversial nature, a discussion of the contentious articles (namely, Articles 5 and 7) was presented after the brief introduction to the Convention's content. In the end, however, and despite contention, the UNWC gained a position as a codification of the customary international law in accordance with its entry into force, thereby strengthening and elevating its functions on the international stage. These enhanced functions were expounded upon in the last part of the introduction to the UNWC.

The introductory section is followed by a focal part in this chapter, namely the analysis of how to use the UNWC as a basis for improvement of the Mekong water regime. In the analysis, the author first expresses the reasons why the UNWC should be chosen as a basis for improvement. According to author's analysis, we discover that an effective UNWC now can provide adequate support to the Mekong River management and protection efforts in various respects, for instance, by generating international pressure on Mekong River issues, strengthening the legal basis of the 
Mekong water legal regime, and fostering regional cooperation on Mekong River development, among others. Secondly, as an international framework for transboundary watercourses management, the UNWC is a fundamental document for guiding the legal basis of the Mekong water legal regime. Therefore, the author carried out an analytical comparison between the UNWC and the only specific legal instrument of the Mekong water regime, the 1995 Mekong Agreement, and identified their differences. Based on these differences, the author determined that the 1995 Mekong agreement is neither sufficiently comprehensive nor sufficiently effective, and that the differences between these two instruments can act as springboards for efforts to improve of the 1995 Mekong Agreement while also providing these efforts with a sense of direction.

The core of the second part of this chapter, i.e. ways to improve of the Mekong water regime, is based on the contents of the chapters preceding it: the assessment of the Mekong water regime in the Chapter 2, the functional comparison in the Chapter 3, and the comparison between the UNWC and the 1995 Mekong Agreement. These ways have been divided into three aspects. The first aspect is improving the legal basis of the Mekong water regime. In addition to the points based on the comparison between the 1997 UNWC and the 1995 Mekong Agreement, some mechanisms, such as public participation and transboundary EIA, need to be improved in the Mekong water regime and confirmed by the regime's legal basis, and implementation at the national level is also an important point to be considered.

The second aspect is enhancing the role of the Mekong River Commission. As the author has explained, the target is to achieve the "triple bottom line", and several recommendations for how this can be achieved are given. These recommendations include: combining improvement of the legal basis with improvement of the MRC, connecting the work of the MRC with the national level, applying the MRC's knowledge more effectively, enhancing stakeholder and community involvement, enhancing the MRC's relationship with other Mekong related instruments, establishing an inspection panel for MRC's development programs. The MRC's engagement with the donors and NGOs is also an important point for improving the MRC's role.

The last aspect discussed was how to involve China in the Mekong water regime. In this section, the author analyzes the reason why the Mekong regime needs China's 
involvement. The feasibility of China's involvement, as well as the potential benefit this involvement could bring, are portrayed, and the section is concluded with a discussion of how Chinese involvement can (and why it should) be realized. In accordance with the current reality of the situation, the author suggested that the involvement of China in the Mekong water legal regime be partial in nature and based on the MRC's development programs and other cooperative efforts between China and other riparian countries; for instance, the new Lancang-Mekong Cooperation Mechanism and the GMS program could be a very suitable "bridge" for this partial involvement.

In summary, this chapter focuses improving the Mekong water regime. The content of the 1997 UNWC provides a very appropriate example for improving the content of the regime's legal basis. The functional comparison in the former chapter revealed that the functions of the MRC focus entirely too much on economic growth and ignore the ecological and sustainable development of the Mekong River basin. Therefore, the improvement of MRC's role should follow the "triple bottom line" (social, economic, environmental development) and consider environmental protection and stakeholder involvement to greater extent. Additionally, China's involvement in the Mekong water regime is quite significant for the future development. This chapter not only provides suggestions for improvement of it legal basis, but also for improvement of its institutional aspects, i.e. of the MRC's role. These suggestions are meaningful for the future development of management efforts in the Mekong River basin, as well as offering a great deal of useful information for regional cooperation. 


\section{Chapter 5. Conclusion}

In the chapters above, the author has presented a comprehensive picture of the international legal water regime of the Mekong River basin. This was achieved not only by introducing and analyzing the regime itself, but also by drawing comparisons to another regime and another legal instrument. Based on these analyses and comparisons, the author then set forth suggestions for improvements to the international legal water regime of the Mekong River basin in the last chapter preceding the conclusion.

Chapter 1 is the general introduction of this dissertation. The author introduced firstly the reason why she chooses this theme for the research and the aim of this research. The aim of this dissertation is to clarify the international legal water regime of the Mekong River basin, and also to find the ways to improve it. The structure of the thesis has also been introduced briefly after explained the research question. Then the literature referenced has been summarized. Moreover, an explication of the methodology utilized follows this, expounding the research methods used in this dissertation. The author's main tool to achieve this was the comparison method. Reflections on this method include not only the functional comparison in Chapter 3, which is unique in that it focuses only on the regime's functions, but also in Chapter 4 when the author makes suggestions for improvements on the legal basis of the Mekong Regime and uses the 1997 UNWC as a model for this improvement. The introductory chapter is meant to give readers a general impression of this dissertation. The readers will be able to glean enough from this chapter to get a "blueprint" of the author's aim in designing the article's structure and the tools used to achieve its objectives.

On the basis of the structure and methods of research mentioned in the introductory chapter, Chapter 2 initiates a legal analysis of the Mekong water regime. This chapter lays the foundation for understanding the following chapters, which includes much in the way of basic knowledge and relevant discussion on the regime's current situation. Firstly, the author introduced the geological, social-political, and domestic context of the Mekong Water Regime, all of which constitute eminently important facts and foundations for the Regime's construction and development. And then, the author drew a general picture of the legal basis of the international water regime in the Mekong river basin. This legal basis is crucial for establishing the legitimacy of the 
regime and its development, and has thus been illustrated at three different levels: the international level, the level of specialized regional instruments, and the level of related regional arrangements. At the international level, we found a series of specialized legal instruments related to the management of water resources in a transboundary river basin, including the Helsinki Rules, the 1997 UNWC, and the Berlin Rules. Others, related sources of international environmental law, such as the Convention on Biological Diversity, the Convention on the Conservation of Migratory Species of Wild Animals, the Ramsar Convention, as well as of general international environmental law, such as the Stockholm Declaration and the Rio Declaration, have also provided a great deal of support in the development of the Mekong water regime.

As stated above, the regional specialized instrument known as the 1995 Mekong Agreement is the core of the legal basis of the Mekong water regime. It is the only specialized legal instrument for water resource management of the Mekong River basin. It is also the basis for the only specialized regional organization, the Mekong River Commission, for water resource management in the Mekong River basin.

Additionally, a number of other, related regional instruments also support the Mekong water regime in different respects; these include the GMS program, the Global Water Partnership Southeast-Asia, the ASEAN-Mekong Basin Development Cooperation, and the ASEAN Working Group on Water Resource Management.

After introducing the legal basis of the Mekong water regime, the author presented a more explicit analysis of the core legal basis, the 1995 Mekong Agreement, and its institution, the Mekong River Commission. This analysis is also the emphasis of Chapter 2, wherein, firstly, the historical background of the 1995 Mekong Agreement and its institution were expounded and two periods before the 1995 Mekong Agreement were clearly described. Then, the process of negotiating the 1995 Mekong Agreement, the key points that arose during negotiations, as well as the factors that led to the success of the negotiation were all clarified. This focus on the history behind the Mekong water regime helps readers to get a general impression of its purpose and a deeper understanding of why the 1995 Mekong Agreement was established.

This historically relevant content is followed by an analysis of the 1995 Mekong Agreement's content and the structure of its institution, the MRC. After first 
introducing the aim of the 1995 Mekong Agreement, the author expounds each of the Agreement's objectives one by one. Last but not the least, the author illustrates the principles of the Agreement, comparing and contrasting them with general principles of international environmental law, thereby drawing a clear picture of the relationship between the general principles of international law and international environmental law, and the principles in a regional environmental instrument. All of the institutional and procedural provisions of the Mekong Agreement all concern themselves with the institution established based on this Agreement, the Mekong River Commission. Therefore, any analysis of these provisions can be seen as an analysis of the Mekong water regime's institution. This section explains the legal personality and the organizational structure of the MRC; thereafter, it introduces the National Mekong Committee (NMC) as a part of the MRC, as well as other functions of this regional institution, such as dispute resolution, information exchange and sharing, information reporting (namely notification, prior consultation, agreement), funding and financing. Finally, this section contains an illustration of the relationship between the MRC and other regional water-related instruments and initiatives.

The basic content of the 1995 Mekong Agreement and the MRC is the foundation for us to understand the Mekong water regime, and also the foundation for further research. Besides these basic contents, the complex relationships in the Mekong water regime are also important elements the author's research focuses on, especially as it concerns the aim of this dissertation, i.e. ways to improve the Mekong water regime. This includes the relationship between the MRC and the national interests, the relationship between the Mekong water regime and China, and the relationship between the Mekong water regime and its donors.

At the end of Chapter 2, the author gives an assessment of the current Mekong water regime based on the analysis of its basic contents as well as its internal and external relationship grid. This assessment can be considered a fountainhead of improvements to the Mekong water regime. Two obvious characteristics of the 1995 Mekong Agreement have been expressed in this section. One is that its principles are very broad. The other is that it has a flexible framework and is subject to a continuous dialogue and negotiation process. Therefore, the author then divided the assessment into two aspects: a substantive assessment and a procedural/institutional assessment. The drawbacks due to the characteristics of the legal basis have been reflected in both 
of these two aspects. The author intent in analyzing these drawbacks and the reasons behind them was to attempt to establish a good basis for the chapters to follow.

After comprehensively analyzing the Mekong water regime, the deeper research necessary to make a functional comparison between the Mekong water regime and the Rhine water regime is presented. The whole of Chapter 3 is dedicated to this topic. Because the functions of these two regimes are implemented through their institutions, this is essentially a functional comparison of two transboundary river institutions. While one reason for comparing the functions of these two regimes is to identify their differences, another is to draw inspiration from these differences and contribute to the improvement of the Mekong water regime.

In the first section of the Chapter 3, the author introduces the functions of the Mekong water regime one by one under different headlines. They include integration, functions for people, agriculture, flood and drought, climate change, navigation, environmental health, hydropower, water quality, and fishery. For each function, the author introduces its meaning, its legal basis or instruments, and also its implementation. As a summary for the expression of these functions, the author found that all of these functions focus mainly on the economic development of the Mekong River basin. Although the aim of the Mekong water regime is to promote sustainable regional development, but functions of the Mekong water regime ignore the social and environmental development aspects. Then, the author analyzed the reasons behind this current status, which were also covered in the improvement chapter.

After introducing the Mekong water regime's functions, the next phase of the functional comparison is the comparison itself. In this section, the author has attempted to compare the functions of the Mekong and Rhine water regimes. The first step of the comparison is to introduce the other subject in it, which in this case is the Rhine water regime. The author thus drew a brief picture of the Rhine water regime and built a foundation for the functional comparison to follow: firstly, by expressing the history of the evolution of the Rhine water regime; secondly, by analyzing the three most important legal bases, i.e. the Convention on the Protection of the Rhine, the European Water Framework Directive and the Floods Directive. The institutional organization of the Rhine water regime, namely the Rhine Commission, was introduced afterwards. Last but not least, the author summarized the preceding introduction of the Rhine water regime and also provided a brief assessment thereof. 
This assessment makes it clear that the Rhine water regime also has numerous functions for different aspects, and that all of its functions can be denominated in the same way as the functions of the Mekong water regime.

The second step of this section is also the core of this chapter: the functional comparison of the Mekong water regime and the Rhine water regime. Given the analysis of the functions of the Mekong water regime introduced in the preceding section, the author followed the order in which the functions were introduced in that section and divided the functional comparison into several, smaller comparisons. Each small comparison corresponds to one function. In one small comparison, the author first introduced this function in the Rhine water regime, and then began comparing and analyzing this function in two different regimes. This structure helps the reader to understand very clearly the difference between the expressions of each function in these two regimes. After finishing all these small comparisons for different functions, the author provides a comprehensive summary collecting all of the information from each small comparison in order to furnish a more comprehensive and analytical result for the functional comparison. This result showed that, although we may be superficially capable of giving a function the same name in these two regimes, in fact these functions manifest themselves differently in the Rhine and Mekong water regimes due to the different aims, different degrees of regional development, different legal basis and also different regional characteristics of the regimes. The most important of these differences is that the two regimes set different aims for themselves. The Mekong water regime focuses chiefly on economic development, while the Rhine water regime primarily concentrates on environment protection. Moreover, the implementation of these functions in the Rhine water regime is better than in the Mekong water regime due to a more comprehensive and effective legal basis that also leads to a more efficient institution. Each one of the small comparisons for each function of these two regimes and the analytical and comprehensive summary at the end of this section are very meaningful and important. This is not only because they expose the essential differences between the functions in these two regimes, but also because of their effect on the next chapter, which provides a good foundation for improvement of the Mekong water regime.

Thus, the last chapter in the main body of the dissertation discusses the improvement of the Mekong water regime. In addition to the analysis gained from the functional 
comparison, another comparison of two legal instruments, the 1995 Mekong Agreement and the 1997 UNWC, is also a crucial foundation for improvement of the Mekong water regime. Therefore, the first part of Chapter 4 focuses on this comparison and into considerable depth on the essential differences between these two international legal instruments. First of all, the author introduced the 1997 UNWC by analyzing its historical background, contents, most contentious articles, and its functions after entering into force. This introduction let readers know what the 1997 UNWC is, which is important for their understanding of the explanation that follows. Secondly, after introducing the UNWC, the author also expounds reasons for choosing the 1997 UNWC as a subject of the comparison and as a basis for improvement of the Mekong water regime. Thirdly, based on the contents of Chapter 2, namely the part that includes the introduction of the 1995 Mekong Agreement, and the former section introducing the 1997 UNWC, the author raises 14 points about the Mekong water regime requiring improvement. These include groundwater, good faith, equitable and reasonable utilization, obligation not to cause significant harm, etc. Lastly, the author provides a summary that also includes comments on the entire comparison section. The author determines that there are several points that must be added to the 1995 Mekong Agreement, and several points that already existed in the 1995 Mekong Agreement but are not sufficiently comprehensive or explicit must be supplemented and improved. The author explains the reasons behind the obvious weakness of the 1995 Mekong Agreement, namely, that it is too abstract and not explicit enough, in this summary; fortunately, the points made prior can point us in the right direction for improving it. Moreover, the author points out that there are also other points that must be considered to improve the 1995 Mekong Agreement in addition to those based on the comparison with the 1997 UNWC. These are the mechanism of public participation, the mechanism of transboundary environmental impact assessment, and the enforcement at the national level.

According to these two comparisons and also the content introduced in preceding sections, the second part of Chapter 4 then starts to achieve the goal of this dissertation, namely the identification of ways to improve the Mekong water regime. These are divided into three main aspects: the improvement of its legal basis, the improvement of its institution, and the involvement of China. Firstly, the legal basis should be more explicit and effective. The Mekong agreement should improve the 
points identified in the comparison with the 1997 UNWC. Additionally, this sole legal basis for the Mekong water regime must be more ecosystem-oriented and not overfocus on regional economic development. The functional comparison also contends that the implementation of the legal basis must be improved as well. An effective method for improving its implementation is to analyze more details of the functions of the Mekong water regime and the regional realities of the Mekong region by formulating related non-legally binding procedures based on the Mekong Agreement. Additionally, implementation at the national level has also been considered. For this point, the author suggests that every member country enact specific legislation for adopting the 1995 Mekong Agreement and its relevant procedures. Moreover, the author believes that transboundary EIA and public participation are also two vital points that must be strengthened. These two points must be reflected in the Mekong Agreement itself, or in related MRC procedures and its Programmes on the basis of this agreement.

Secondly, the institutional aspect of improving the Mekong water regime, i.e. improvement of the MRC, is touched upon. The objective of the MRC's work is to achieve the "triple bottom line". Therefore, improvements to the MRC must be combined with improvements to the regime's legal basis; the MRC's work must be connected with realities at the national level; the MRC's knowledge must be applied more effectively; stakeholder and community involvement must be strengthened; the relationship between the MRC and other Mekong related instruments must be improved upon; an inspection panel should be built for the MRC's development programs. The MRC's interaction with donors and NGOs is also an important point for improving the MRC's role.

Last but not least, the author discusses the involvement of China in the Mekong water regime, including the reasons for involving China, the potential thereof, and how it should be brought about. Given the reality of the situation at this time, the author suggests that involvement of China in the Mekong water legal regime should be kept as partial in nature. The MRC's development programs and other cooperative efforts between China and other riparian countries can provide a solid foundation for this involvement.

As a whole, this dissertation tells a very clear story about the Mekong international legal water regime. It provides comprehensive information on what the regime is, 
how it works, and the complicated relationships between all actors within this regime. By comparing the functions of the Mekong water regime and the famous and more mature Rhine regime, the author is able to identify an obvious weakness of the Mekong water regime: its functions focus too much on regional economic development and ignore the other aspects of sustainable development, namely environmental and social development. This finding provides inspiration for improvement of the regime. Furthermore, the author uses the 1997 UNWC as a vital tool for improving its legal basis. All of these sections together lead to the eventual achievement of the aim of this dissertation: to find the ways to improve the Mekong water regime.

There are three novel points made by this dissertation. First of all, this dissertation compares the functions of the Mekong water regime with those of the Rhine water regime. This is not a traditional comparison that compares two regimes in terms of their legal basis or institutional organization. This functional comparison focuses only on the functions or the two regimes, and shows readers the practical meaning behind a regional river regime. Moreover, after the 1997 UNWC entered into force in August of 2014 with Vietnam's ratification, the functions of the UNWC were enhanced. Therefore, the connection between the 1997 UNWC and the Mekong River basin was also strengthened. Against this background, the author analyzes the functions of the 1997 UNWC, and also uses it as a foundation for improvement of the legal basis of the Mekong water regime. Furthermore, this dissertation also includes an in-depth analysis of Chinese involvement in the Mekong water regime, which is also an important point for improvement of the Mekong water regime and enlightens readers on the relationship between China and the Mekong water regime.

We are now in an era of rapid development. Therefore, in order to keep stride with the changes in the world, many existing international law regimes must be improved in many respects. The Mekong water regime is one of those facing this challenge. All in all, the in-depth analysis and feasible ways for improvement of the Mekong water regime set forth in this dissertation are meaningful to get a better understanding of this region and also provide inspiration for future development of the region. 


\section{Acknowledgments}

First and foremost, I would like to thank my supervisor, Professor Peter-Tobias Stoll, from whom I received a great deal of support in writing my dissertation. Every discussion with him and every piece of advice he gave me brought me much in the way of inspiration. He helped me to determine the topic and the structure of my dissertation and provided me with suggestions on how to carry out a functional comparison. Thanks to his assistance, I finished my dissertation within a specific field of international environmental law and also learned many things from carrying out this research. I therefore would once again like to express my heartfelt appreciation for his kind support and encouragement. I also want to thank Professor QIN Tianbao, who supervised of the writing of my Master's thesis in China. He also gave me many suggestions for my research, and as well as useful advice for my life and career. I would especially like to express my appreciation for the encouragement and comfort he and his family gave me during their time in Goettingen from 2012-2014. Next, I would like to thank many of my colleagues from the Institute of International Public Law for their input during the doctoral seminar and the opportunity to discuss our topics together, as well as for their feedback and suggestions. I look back fondly on our lunch and coffee breaks together, during which engaged in discussions, learned from and encouraged each other; the friendship with my colleagues often gave me the energy I needed to continue. I would also like to thank all my friends in Goettingen and China. They always make me feel at home and give me great advice for my life and my future. Without them, I would not have been able to face all the difficulties that I have encountered. Lastly (but certainly not least), I would like to thank my parents for all of their support during my studies in Goettingen. This support includes not only financial support, but spiritual support as well. They respected all my decisions, and always encouraged me when I felt frustrated. In China, we have a famous saying: "The heart of parents is the most precious thing in the world". They make me more brave and confident, and have provided me a mental and spiritual "lighthouse" to guide me in my future navigation of the unknown world. I will remember all of these kindnesses and encouragements for the rest of my life, and try my best to overcome the difficulties on the way of achieving my goals. 


\section{Reference}

\section{Legally and Non-legally Binding Documents}

[1] Charter of the United Nations [1945] Stat. 59/1031; TS 993; Bevans 3/1153 $<$ https://treaties.un.org/doc/publication/ctc/uncharter.pdf > accessed 26 October 2016

[2] The Helsinki Rules on the Uses of the Waters of International Rivers [1966] International Law Association, Report of the 52nd Conference 484 (1967) <http://www.fao.org/docrep/005/W9549E/w9549e08.htm\#bm08.2.5> accessed 26 October 2016

[3] The Convention on Wetlands of International Importance [1971] UNTS 996/245; TIAS 11084; ILM 11/963 (1972)

<http://www.ramsar.org/sites/default/files/documents/library/scan_certified_e.pdf> accessed 26 October 2016

[4] Declaration of the United Nations Conference on the Human Environment [1972] U.N. Doc. A/Conf.48/14/Rev. 1(1973); ILM 11/1416 (1972)

$<$ http://www.unep.org/documents.multilingual/default.asp?documentid=97\&articleid $=1503>$ accessed 26 October 2016

[5] Recommendation of the Council on Guiding Principles concerning International Economic Aspects of Environmental Policies [1972] OECD, C(72)128 $<$ http://acts.oecd.org/Instruments/ShowInstrumentView.aspx? InstrumentID=4\&Lang $=$ en $>$ accessed 26 October 2016

[6] Environmental Law Guidelines and Principles on Shared Natural Resources [1978] UNEP $<$ http://www.unep.org/training/programmes/Instructor\%20Version/Part_2/Activities/I nterest_Groups/Decision-

Making/Supplemental/Enviro_Law_Guidelines_Principles_rev2.pdf> accessed 26 October 2016

[7] Convention on the Conservation of Migratory Species of Wild Animals [1979] UNTS 1651/333; ILM 19/15 (1980); ATS 1991/32; BTS 87 (1990), Cm. 1332 <http://www.cms.int/sites/default/files/instrument/CMS-text.en_.PDF> accessed 26 October 2016 
[8] The World Charter for Nature [1982] G.A. Res. 37/7, U.N. GAOR, 37th Sess., Supp. No. 51, at 17, U.N. Doc. A/37/51 (1982); ILM 22/455 (1983)

<http://www.un.org/documents/ga/res/37/a37r007.htm> accessed 26 October 2016

[9] Code of Conduct on Accidental Pollution of Transboundary Inland Waters [1990]

UNECE, United Nations Publication Sales No. 90 E. II. 28

$<$ http://www.unece.org/fileadmin/DAM/////env/water/publications/documents/Library /Old_documents_found_library/ECE_ENVWA_16_eng.pdf> accessed 26 October 2016

[10] Convention on Environmental Impact Assessment in a Transboundary Context [1991] UNECE, ECE/MP.EIA/21

<http://www.unece.org/fileadmin/DAM/env/eia/documents/legaltexts/Espoo_Convent ion_authentic_ENG.pdf> accessed 26 October 2016

[11] Agenda 21 [1992] UNEP, U.N. GAOR, 46th Sess., Agenda Item 21, UN Doc A/Conf.151/26 (1992)

$<$ http://www.unep.org/documents.multilingual/default.asp?documentid=52> accessed 26 October 2016

[12] Convention on Biological Diversity [1992] UNTS 1760/79; ILM 31/818 (1992) <https://www.cbd.int/doc/legal/cbd-en.pdf> accessed 26 October 2016

[13] Convention on the Protection and Use of Transboundary Watercourses and International Lakes [1992] UNTS 1936/269; ILM 31/1312 (1992)

<https://www.unece.org/fileadmin/DAM/env/water/pdf/watercon.pdf> accessed 26 October 2016

[14] Rio Declaration on Environment and Development [1992] UN Doc.

A/CONF.151/26 (vol. I); ILM 31/874 (1992)

$<$ http://www.unep.org/Documents.Multilingual/Default.asp?DocumentID=78\&Articl eID $=1163>$ accessed 26 October 2016

[15] Convention on Cooperation for the Protection and Sustainable Use of the Danube River [1994] OJ L 342/19 <https://www.icpdr.org/main/icpdr/danube-riverprotection-convention> accessed 26 October 2016

[16] Convention to Combat Desertification [1994] UNTS 1954/3; ILM 33/1328 (1994) $<$ http://www.unccd.int/en/about-the-convention/Pages/Text-overview.aspx > accessed 26 October 2016 
[17] Agreement on the Cooperation for the Sustainable Development of the Mekong River Basin [1995] ILM 34/864 (1995)

<http://www.mrcmekong.org/assets/Publications/policies/agreement-Apr95.pdf> accessed 26 October 2016

[18] Basic Framework of ASEAN- Mekong Basin Development Cooperation [1996] AMBDC

<http://www.asean.org/storage/images/2012/Economic/AMBDC/Basic\%20Framewor k\%20of\%20ASEAN-\%20Mekong\%20Basin\%20Development\%20Cooperation.pdf> accesses 02 October 2016.

[19] Convention on the Law of the Non-Navigational Uses of International

Watercourses [1997] ILM 36/700 (1997); G.A. Res. 51/229, U.N. GAOR, 51st Sess., 99th mtg., UN Doc A/RES/51/229 (1997)

$<$ http://legal.un.org/ilc/texts/instruments/english/conventions/8_3_1997.pdf> accesses 02 October 2016.

[20] Convention on Access to Information, Public Participation in Decision-making and Access to Justice in Environmental Matters [1998] UNTS 2161/447; ILM 38/517 (1999) <http://www.unece.org/fileadmin/DAM/env/pp/documents/cep43e.pdf> accessed 26 October 2016

[21] Convention on the Protection of the Rhine [1999] TIAS 11085; UNTS 1506/157 <http://www.iksr.org/fileadmin/user_upload/Dokumente_en/convention_on_tthe_prot ection_of_the_rhine.pdf> accessed 26 October 2016

[22] Directive 2000/60/EC of the European Parliament and of the Council of 23

October 2000 establishing a Framework for Community Action in the Field of Water Policy [2000] OJ L 327/1 (2000) <http://eur-

lex.europa.eu/LexUriServ/LexUriServ.do?uri=CELEX:32000L0060:EN:HTML> accessed 26 October 2016

[23] Procedures for Data and Information Exchange and Sharing [2001] Mekong River Commission <http://www.mrcmekong.org/assets/Publications/policies/Procedures-Data-InfoExchange-n-Sharing.pdf > accesses 02 October 2016.

[24] Berlin Rules on Water Resources [2004] International Law Association, Report of the 71st Conference 3 (2004); ILA 71/337, 385 (2004) 
<http://internationalwaterlaw.org/documents/intldocs/ILA_Berlin_Rules-2004.pdf> accessed 26 October 2016

[25] ASEAN Strategic Plan of Actions on Water Resources Management [2005]

\section{ASEAN}

$<$ http://environment.asean.org/files/ASEAN\%20Strategic\%20Plan\%20of\%20Action \%20on\%20Water\%20Resources\%20Management.pdf> accesses 02 October 2016.

[26] Guidelines on Implementation of the Procedures for Notification, Prior

Consultation and Agreement [2005] Mekong River Commission

$<$ http://www.mrcmekong.org/assets/Publications/policies/Guidelines-on-

implementation-of-the-PNPCA.pdf> accessed 29 September 2016.

[27] Directive of the European Parliament and of the Council (EC) 2006/118 on the protection of groundwater against pollution and deterioration [2006] OJ L 372/19 $<$ http://eur-

lex.europa.eu/LexUriServ/LexUriServ.do?uri=OJ:L:2006:372:0019:0031:EN:PDF> accessed 26 October 2016

[28] Directive 2006/7/EC of the European Parliament and of the Council of 15 February 2006 concerning the management of bathing water quality and repealing Directive 76/160/EEC [2006] OJ L 64/37 (2006) <http://eur-lex.europa.eu/legalcontent/EN/TXT/?uri=CELEX\%3A32006L0007> accessed 28 October 2016.

[29] Procedures for the Maintenance of Flows on the Mainstream [2006] Mekong River Commission <http://www.mrcmekong.org/assets/Publications/policies/Procedures-MaintenanceFlows.pdf> accesses 02 October 2016.

[30] Directive of the European Parliament and of the Council (EC) 2007/60 on the assessment and management of flood risks [2007] OJ L 288/27 <http://eurlex.europa.eu/legal-content/GA/TXT/?uri=celex:32007L0060> accessed 26 October 2016

[31] Statutes Southeast Asia Regional Water Partnership [2008] GWP-SEA <http://www.gwp.org/Global/GWP-SEa_Files/011\%20-\%20GWP-

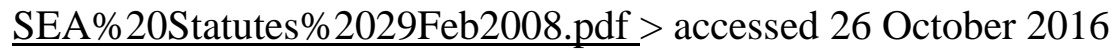

[32] Environmental Programme 2011-2015 [2010] Mekong River Commission $<$ http://mrcmekong.mrcdev.info/assets/Publications/Programme- 
Documents/Environment-Programme-2011-2015-1-November.pdf $>$ accessed 02 October 2016.

[33] Procedures for Notification, Prior Consultation and Agreement [2010] Mekong River Commission

$<$ http://www.mrcmekong.org/assets/Publications/policies/Procedures-NotificationPrior-Consultation-Agreement.pdf> accessed 02 October 2016.

[34] MRC Hua Hin Declaration [2010] Mekong River Commission, Way Ahead <http://www.mrcmekong.org/assets/Publications/Events/MRCSummit2010/MRCHua-Hin-Declaration-05-Apr-10.pdf> accessed 26 October 2016.

[35] Information and Knowledge Management Programme [2010] Mekong River Commission < $<$ ttp://www.mrcmekong.org/assets/Publications/Programme-

Documents/ProDoc-2011-2015final-versionIKMP.pdf> accessed 02 October 2016

[36] European Commission Guidance for Administrations on Making WFD Agricultural Measures Clear and Transparent at Farm Level [2011] European

Commission Directorate-General Environment, Directorate D - Water, Chemicals \& Biotechnology, ENV.D.1 - Water

$<$ http://ec.europa.eu/environment/water/quantity/pdf/guidance_en.pdf $>$ accessed 02 October 2016.

[37] Agricultural and Irrigation Programme [2011] Mekong River Commission <http://www.mrcmekong.org/assets/Publications/Programme-Documents/AIPPogramme-Doc-V4-Final-Nov11.pdf> accessed 02 October 2016.

[38] Programme Document Basin Development Plan Programme 2011-2015 [2011] Mekong River Commission <http://mrcmekong.mrcdev.info/assets/Publications/ProgrammeDocuments/BDP2011-2015-Programme-Doc-June2011.pdf > accessed 02 October 2016

[39] IWRM-based Basin Development Strategy [2011] Mekong River Commission <http://mrcmekong.mrcdev.info/assets/Publications/strategies-workprog/BDP-

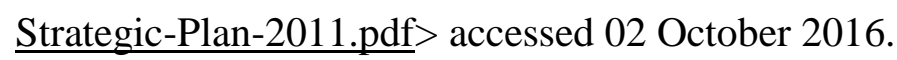

[40] Procedures for Water Quality [2011] Mekong River Commission <http://www.mrcmekong.org/assets/Publications/policies/Procedures-for-WaterQuality-council-approved260111.pdf> accessed 02 October 2016. 
[41] Guidelines on Disclosure of Data, Information and Knowledge [2015] Mekong River Commission <http://www.mrcmekong.org/assets/Publications/policies/MRC-

Disclosure-Guidelines-RevisedVer-May2015-final.pdf> accessed 02 October 2016.

\section{Books}

[1] Albert Henry Garretson, Robert D Hayton, Cecil J Olmstead, Richard Baxter and Ludwick A Teclaff, The Law of International Drainage Basins (New York, 1st, Oceana Publications, 1967)

[2] Alina Kaczorowska-Ireland, Public International Law (UK, 5th, Routledge, 2015)

[3] Astrid Epiney, 'Environmental Impact Assessment', Max Planck Encyclopedia of Public International Law (Fall edn 2009)

<http://opil.ouplaw.com/view/10.1093/law:epil/9780199231690/law-

9780199231690-e1581?rskey=MI8OFW\&result=1\&prd=EPIL $>$ accessed 29

September 2016

[4] Attila Tanzi and Maurizio Arcari, The United Nations Convention on the Law of International Watercourses (Netherlands, 1st, Kluwer Law International, 2001)

[5] Ben Boer, Philip Hirsch, Fleur Johns, Ben Saul and Natalia Scurrah, The Mekong: A Socio-Legal Approach to River Basin Development (New York, 1st, Routledge, 2016)

[6] Christian Walter, 'Subjects of International Law', Max Planck Encyclopedia of Public International Law (Fall edn 2009)

<http://opil.ouplaw.com/view/10.1093/law:epil/9780199231690/law9780199231690-e1018?rskey=EQWcAt\&result=1\&prd=EPIL $>$ accessed 2 October 2016

[7] Flavia Rocha Loures and Alistair Rieu-Clarke (eds), The UN Watercourse Convention in Force: Strengthening International Law for Transboundary Water Management (UK, 1st, Routledge, 2013)

[8] Franois Molle, Tira Foran and Mira Kakonen (eds) Contested Waterscapes in the Mekong Region: "Hydropower, Livelihoods and Governance" (UK, 1st, Earthscan, 2009)

[9] Janice Gray, Cameron Holley and Rosemary Rayfuse (eds), Trans-jurisdictional Water Law and Governance (Florence, 1st, Routledge, 2016) 
[10] J. J. Fried, Groundwater Pollution (Netherland, 1st, Elsevier Science, 1975)

[11] Jonas Ebbesson, 'Public Participation in Environmental Matters', Max Planck

Encyclopedia of Public International Law (Fall edn 2009)

<http://opil.ouplaw.com/view/10.1093/law:epil/9780199231690/law-

9780199231690-e1769?rskey=VdmStq\&result=1\&prd=EPIL $>$ accessed 29

September 2016

[12] Lal Kurukulasuriya and Nicholas A. Robinson (ed), Training Manual on

International Environmental Law (1st, UNEP/Earthprint, 2006)

<http://www.unep.org/environmentalgovernance/Portals/8/documents/training_Manu

al.pdf $>$ accessed 29 September 2016

[13] Laurence Boisson de Chazournes, Fresh Water in International Law (UK, 1st,

Oxford University Press, 2013)

[14] Markus Kotzur, 'Good Faith', Max Planck Encyclopedia of Public International

Law (Fall edn 2009)

<http://opil.ouplaw.com/view/10.1093/law:epil/9780199231690/law-

9780199231690-e1412?rskey=SppiOc\&result=1\&prd=EPIL $>$ accessed 2 October 2016

[15] Owen McIntyre, Environmental Protection of international Watercourses under International Law (UK, 1st edn, Ashgate Publishing, 2007)

[16] Peter de Cruz, 'Comparative Law, Functions and Methods', Max Planck

Encyclopedia of Public International Law (Fall edn 2009)

<http://opil.ouplaw.com/view/10.1093/law:epil/9780199231690/law-

9780199231690-e1018?rskey=EQWcAt\&result=1\&prd=EPIL $>$ accessed 31 October 2016

[17] Philippe Sands, Jacqueline Peel, With Adriana Fabra, With Ruth MacKenzie, Principles of international environmental law (UK, 3rd edn, Cambridge University Press, 2012)

[18] Carl E. Bruch, Public Participation in the Governance of International Freshwater Resources (Tokyo, 1st, United Nations University Press, 2005)

[19] P. W. Birnie and A. E. Boyle, International Law and the Environment (US, 2nd, Oxford University Press, 2002) 
[20] Stephen McCaffrey, The law of international watercourses: Non-navigational uses (UK, 1st edn, Oxford University Press, 2001)

[21] Ulrich Beyerlin, 'Sustainable Development', Max Planck Encyclopedia of Public International Law (Fall edn 2013)

<http://opil.ouplaw.com/view/10.1093/law:epil/9780199231690/law-

9780199231690-e1609?rskey=x0kyma\&result=1\&prd=EPIL> accessed 29

September 2016

\section{Articles}

[1] Albert Park, Sangui Wang, Guobao Wu, 'Regional Poverty Targeting in China' (2002) 86 Journal of Public Economics 123

[2] Alistair Rieu-Clarke, 'Notification and Consultation Procedures Under the Mekong Agreement: Insights from the Xayaburi Controversy' (2015) 5 Asian Journal of International Law 143

[3] Caio Cesar de Araujo Barbosa, John Dearing, 'Evolutionary Social and Biogeophysical Changes in the Amazon, Ganges-Brahmaputra-Meghna and Mekong Deltas' (2016) 11 Sustainability Science 555

[4] Chea R, Grenouillet G, Lek S, 'Evidence of Water Quality Degradation in Lower Mekong Basin Revealed by Self- Organizing Map' (2016) 11/1: e0145527. PLoS ONE

<http://journals.plos.org/plosone/article/asset?id=10.1371/journal.pone.0145527.PDF> accessed 27 October 2016.

[5] Chu Thai Huanh and Thierry Facon, 'Irrigation in the Lower Mekong Basin Countires: The Beginning of a New Era?' Franois Molle, Tira Foran and Mira Kakonen (eds) Contested Waterscapes in the Mekong Region: "Hydropower, Livelihoods and Governance" (UK, 1st, Earthscan, 2009) 143

[6] Claudia Kuenzer, Ian Campbell, Marthe Roch, Patrick Leinenkugel, Vo Quoc Tuan, Stefan Dech 'Understanding the Impact of Hydropower Developments in the Context of Upstream-Downstream Relations' (2013) 8/4 Sustainability Science 565

[7] Chris Sneddon and Coleen Fox, 'Power, Development, and Institutional Change: Participatory Governance in the Lower Mekong Basin' (2007) 35/12 World Development 2161 
[8] D. G. Kingston, J. R. Thompson and G. Kite, 'Uncertainty in Climate Change Projections of Discharge for the Mekong River Basin' (2011) 15 Hydrology and Earth System Sciences 1459, 1459-60.

[9] Ellen Bruzelius Backer, 'The Mekong River Commission: Does It Work, and How Does the Mekong Basin's Geography Influence Its Effectiveness?' (2007) 4

Südostasien aktuell: journal of current Southeast Asian affairs 31

[10] Erik Mostert, 'The European Water Framework Directive and water management research' (2003) 28 Physics and Chemistry of the Earth 523

[11] Fleur E. Johns, Ben Saul, Philip Hirsch, Tim Stephens, Ben Boer, 'Law and the Mekong River Basin: A Socio-Legal Research Agenda on the Role of Hard and soft Law in Regulating Transboundary Water Resources' (2010) 11 Melbourne Journal of International Law 1

[12] Gabriel Eckstein (ed), 'Specially invited opinions and research report of the International Water Law Project: global perspectives on the entry into force of the UN Watercourses Convention 2014: part one' (2014) 16 Water Policy 1198

[13] Gabriel Eckstein (ed), 'Specially invited opinions and research report of the International Water Law Project: global perspectives on the entry into force of the UN Watercourses Convention 2014: part two' (2015) 17 Water Policy 162

[14] Greg Browder, 'An Analysis of the Negotiations for the 1995 Mekong Agreement' (2000) 5 International Negotiation 237

[15] Greg Browder and Leonard Ortolano, 'The Evolution of an International Water Resources Management Regime in the Mekong River Basin’ (2000) 40 Nat.

Resources J 499

[16] G.T. (Tom) Raadgever, Erik Mostert, Nicole Kranz, Eduard Interwies and Jos G. Timmerman, 'Assessing Management Regimes in Trans-boundary River Basins: Do They Support Adaptive Management?' (2008) 13 Ecology and Society <http://www.ecologyandsociety.org/vol13/iss1/art14/> accessed 29 September 2016 [17] Guy Ziva, Eric Baran, So Nam, Ignacio Rodríguez-Iturbed and Simon A. Levina, 'Trading-off Fish Biodiversity, Food Security, and Hydropower in the Mekong River Basin' (2012) 109 Proceedings of the National Academy of Science of the United State of America 5609 
[18] Haiyun Chen, Ting Zhu, 'The complexity of cooperative governance and optimization of institutional arrangements in the Greater Mekong Subregion' (2016) 50 Land Use Policy 363

[19] H. Middelkoop, K. Daamen, D. Gellens, 'Impact of Climate Change on Hydrological Regimes and Water Resources Management in the Rhine Basin' (2001) 49/1 Climatic Change 105

[20] Hoang Huu Nguyen, Paul Dargusch, Patrick Moss, Da Binh Tran, ‘A review of the drivers of 200 years of wetland degradation in the Mekong Delta of Vietnam' (2016) Regional Environmental Change <http://link.springer.com/article/10.1007\%2Fs10113-016-0941-3> accessed 27 October 2016.

[21] Ingjerd Haddeland, Dennis P. Lettenmaier and Thomas Skaugen 'Effects of irrigation on the water and energy balances of the Colorado and Mekong river basins' (2006) 324 Journal of Hydrology 210

[22] Jeffrey W. Jacobs, 'Mekong Committee History and Lessons for River Basin Development' (1995) 161/2 The Geographical Journal 135

[23] Jeffrey W. Jacobs, 'The Mekong River Commission: transboundary water resources planning and regional security' (2002) 168/4 The Geographical Journal 354 [24] Jing Ma, Keith W. Hipel, Mitali De and Jun Cai, 'Transboundary Water Policies: Assessment, Comparison and Enhancement' (2008) 22/8 Water Resources Management 1069

[25] Jonathan Chenoweth, 'International River Basin Management: Data and Information Exchange under International Law and the Case of the Mekong River Basin' (2000) 18/2 Journal of Energy \& Natural Resources Law 142

[26] Joseph W. Dellapenna, 'The Customary International Law of Trans-boundary Fresh Waters' (2001) 1 Int. J. Global Environmental Issues 264

[27] Julia Martin-Ortega, Giacomo Giannoccaro and Julio Berbel, 'Environmental and Resource Costs Under Water Scarcity Conditions: An Estimation in the Context of the European Water Framework Directive' (2011) 25 Water Resources Management 1615

[28] Katsuhiko Yamauchi, 'Climate change impacts on agriculture and irrigation in the Lower Mekong Basin' (2014) 12 Paddy and Water Environment 227 
[29] Kayo Onishi, 'Interstate negotiation mechanisms for cooperation in the Mekong river basin' (2011) 32 Water International 524

[30] Le Thi Viet Hoa, Nguyen Huu Nhan, Eric Wolanski, Tran Thanh Cong and Haruyama Shigeko, 'The Combined Impact on the Flooding in Vietnam's Mekong River Delta of Local Man-made Structures, Sea level rise, and Dams Upstream in the River Catchment' (2007) 71 Estuarine, Coastal and Shelf Science 110

[31] Mac Kirby, Chayanis Krittasudthacheewa, Mohammed Mainuddin, Eric KempBenedict, Chris Swartz \& Elnora de la Rosa, 'The Mekong: A Diverse Basin Facing the Tensions of Development' (2010) 35/5 Water International 573

[32] Markus Disse and Heinz Engel, 'Flood Events in the Rhine Basin: Genesis, Influences and Mitigation' (2001) 23 Natural Hazards 271

[33] Matthias Ruff, Miriam S. Mueller, Martin Loos, Heinz P. Singer, 'Quantitative target and systematic non-target analysis of polar organic micro-pollutants along the river Rhine using high-resolution mass- spectrometry e Identification of unknown sources and compounds' (2015) 87 Water Research 145

[34] Matti Kummu, Olli Varis, 'Sediment-related impacts due to upstream reservoir trapping, the Lower Mekong River' (2007) 85 Geomorphology 275

[35] Mauricio E. Ariasi, Thomas A. Cochrane and Vittoria Elliott, 'Modelling future changes of habitat and fauna in the Tonle Sap wetland of the Mekong' (2014) 41/2 Environmental Conservation 165

[36] Mi-Jung Bae, Young-Seuk Park, 'Biological early warning system based on the responses of aquatic organisms to disturbances: A review' (2014) 466-477 Science of The Total Environment 635

[37] Mohammed Mainuddin and Mac Kirby, 'Agricultural productivity in the lower Mekong Basin: trends and future prospects for food security' (2009) 1 Food Security 71

[38] Nathalie Plum, Anne Schulte-Wülwer-Leidig 'From a sewer into a living river: the Rhine between Sandoz and Salmon' (2014) 729 Hydrobiologia 95

[39] O.F. Schoumans a, W.J. Chardon, M.E. Bechmann, C. Gascuel-Odoux, G. Hofman, B. Kronvang, G.H. Rubæk, B. Ulén, J.-M. Dorioz, 'Mitigation options to reduce phosphorus losses from the agricultural sector and improve surface water quality: A review' (2014) 468-469 Science of the Total Environment 1255 
[40] Olli Varis, Muhammad M. Rahaman and Virpi Stucki, 'The Rocky Road from Integrated Plans to Implementation: Lessons Learned from the Mekong and Senegal River Basins' (2008) 24/1 Water Resources Development 103

[41] Owen McIntyre, 'The Protection of Freshwater Ecosystems Revisited: Towards a Common Understanding of the 'Ecosystems Approach' to the Protection of Transboundary Water Resources' (2014) 23/1 RECIEL 88

[42] Owen McIntyre, 'The Role of Customary Rules and Principles in the Environmental Protection of Shared International Freshwater Resources' (2006) 46 Natural Resource Journal 157

[43] Owen McIntyre, 'Utilization of shared international freshwater resources - the meaning and role of "equity" in international water law' (2013) 38/2 Water International 112

[44] Peter Beaumont, 'The 1997 UN Convention on the Law of Non- navigational Uses of International Watercourses: Its Strengths and Weaknesses from a Water Management Perspective and the Need for New Workable Guidelines' (2000) 16 Water Resources Development 475

[45] Prachoom Chomchai, 'Public Participation in Watershed Management in Theory and Practice' Carl E. Bruch, Public Participation in the Governance of International Freshwater Resources (Tokyo, 1st, United Nations University Press, 2005) 139

[46] R Edward Grumbine, John Dore and Jianchu Xu, 'Mekong hydropower: drivers of change and governance challenges' (2012) 10/2 Frontiers in Ecology and the Environment 91

[47] Richard Kyle Paisly, Patrick Weiler and Taylor Henshaw, 'Transboundary Waters Governance through the Prism of the Mekong River Basin' Janice Gray, Cameron Holley, Rosemary Rayfuse (eds), Trans-jurisdictional Water Law and Governance (UK, 1st edn, Routledge, 2016) 43

[48] Rob S. E. W. Leuven, Gerard van der Velde, Iris Baijens, Janneke Snijders, Christien van der Zwart, H. J. Rob Lenders, Abraham bij de Vaate, 'The river Rhine: a global highway for dispersal of aquatic invasive species' (2009) 11 Biological Invasions 1989 
[49] Salman M. A. Salman, 'The Helsinki Rules, the UN Watercourses Convention and the Berlin Rules: Perspectives on International Water Law' (2007) 23 Water Resources Development 625

[50] Scott C. Armstrong, 'Water Is for Fighting: Transnational Legal Disputes in the Mekong River Basin’ (2015) 17 Vermont Journal of Environmental Law 1

[51] Stephen C. McCaffrey, 'An overview of the UN Convention on the Law of the Non-Navigational Uses of International Watercourses' (2000) 20 J. Land Resources \& Envtl. L. 57

[52] Stephen C. McCaffrey, 'The Convention Enters Into Force' (2014) 44/4 Environmental Policy and Law 351

[53] Stephen C. McCaffrey, 'The Need for Flexibility in Fresh Water Treaty Regimes' (2003) 27 Natural Resources Forum 156

[54] Stefan Lindemann, 'Water Regime Formation in Europe: A Research Framework with Lessons from the Rhine and Elbe River Basins' (2006) Available at SSRN <https://ssrn.com/abstract=925653> or <http://dx.doi.org/10.2139/ssrn.925653> accessed 27 October 2016.

[55] Takao Masumoto, Pham Thanh Hai and Katsuyuki Shimizu, 'Impact of paddy irrigation levels on floods and water use in the Mekong River basin' (2008) 22 Hydrological Processes 1321

[56] Thomas Bernauer, Peter Moser, 'Reducing the Pollution of the River Rhine: The Influence of International Cooperation' (1996) 5/4 The Journal of Environment Development 389

[57] Toshihiro Sakamoto, Nhan Van Nguyen, Hiroyuki Ohno, Naoki Ishitsuka and Masayuki Yokozawa, 'Spatio-temporal Distribution of Rice Phenology and Cropping Systems in the Mekong Delta with Special Reference to the Seasonal Water Flow of the Mekong and Bassac Rivers' (2006) 100 Remote Sensing of Environment 1

[58] Truong-Minh $\mathrm{Vu}$, 'Between system maker and privileges taker: the role of China in the Greater Mekong Sub-region' (2014) 57 Revista Brasileira de Política Internacional 157

[59] Vytautas Paulauskas, 'Navigational risk assessment of ships' (2006) 21/1 Transport 12 
[60] Xiaojuan Ping, 'Resources for China-ASEAN January 2016 to March 2016: Chronology of Events' (2016) 14/2 China: An International Journal 201

[61] Yanmei He, 'China's practice on the non-navigational uses of transboundary waters: transforming diplomacy through rules of international law' (2015) 40 Water International 312

[62] Yuanling $\mathrm{Xu}$, 'Research on the China-ASEAN Cooperative Legal Regime for the International River Protection’ (DPhil thesis, University of Chongqing 2011)

[63] Yuening Long, 'Research on the International Cooperation Legal Mechanism of the Water Resources in the Mekong River Basin' (DPhil thesis, Kunming University of Science and Technology 2014)

\section{Reports and Working Papers}

[1] Barbara Hall and Sopheak Meas (ed), 'First Rhine-Mekong Symposium: Climate Change and its Influence on Water and Related Sectors' (2014) Mekong River Commission Symposium report <http://www.mrcmekong.org/assets/Publications/Reports/First-Rhine-Mekongsymposium-report.pdf> accessed 29 September 2016

[2] Ellen Bruzelius Backer, 'Paper Tiger Meets White Elephant?' (2006) The Fridtjof Nansen Institute Report 15/2006 <http://www.fni.no/pdf/FNI-R1506.pdf> accessed 29 September 2016

[3] Francesca Somma (ed), 'River Basin Network on Water Framework Directive and Agriculture' (2013) Reference Report by the Joint Research Centre of the European Commission <http://publications.jrc.ec.europa.eu/repository/bitstream/JRC81647/lbna-25978-en-n.pdf> accessed 29 September 2016

[4] George E. Radosevich, Douglas C. Olson, 'Existing and Emerging Basin Arrangements in Asia: Mekong River Commission Case Study' (1999) The World Bank, Third Workshop on River Basin Institution Development, 4 $<$ http://siteresources.worldbank.org/INTWRD/918599-

1112615943168/20431963/MekgongRiverComCaseStudy.pdf > accessed 25 October 2016

[5] George Radosevich, Olivier Cogels, John Dore, John Metzger, Pech Sokhem, Maaria Curlier and Theressa Etmanski, 'In-Depth Case Study for the Mekong River Basin: the 1995 Agreement on the Cooperation for Sustainable Development of the 
Mekong River Basin System' (2011) GEF Transboundary Freshwater and Marine Legal and Institutional Frameworks Project, International Waters Governance $<$ http://www.internationalwatersgovernance.com/uploads/1/3/5/2/13524076/mekong. pdf> accessed 29 September 2016

[6] ICPR, 'Internationally Coordinated Management Plan 2015 for the International River Basin District of the Rhine' (2015) Bewirtschaftungsplan 2015 IFGE Rhein <http://www.iksr.org/fileadmin/user_upload/Dokumente_en/Brochures/CMP_2015__en.pdf> accessed 27 October 2016.

[7] ICPR, 'Niedrigwasserperioden 2011 im Rheineinzugsgebiet' (2012) ICPR Bericht Nr. 198 <http://www.iksr.org/uploads/media/198_d_01.pdf > accessed 29 September 2016

[8] ICPR, 'Sediment Management Plan Rhine Summary' (2009) ICPR Report No. 175

$<$ http://www.iksr.org/fileadmin/user_upload/Dokumente_en/Reports/Bericht_175e.pd f $>$ accessed 29 September 2016

[9] ICPR, 'Strategy for the IRBD for adapting to climate change' (2015) ICPR Report No. 219

<http://www.iksr.org/fileadmin/user_upload/Dokumente_en/Reports/219_en.pdf> accessed 29 September 2016

[10] Mei Xie, 'Integrated Water Resources Management (IWRM)- Introduction to Principles and Practices' (2006) GEF's International Waters Learn Program: the Africa Regional Workshop on IWRM

<http://pacificwater.org/userfiles/file/IWRM/Toolboxes/introduction\%20to\%20iwrm/ IWRM\%20Introduction.pdf > accessed 29 September 2016

[11] Mekong River Commission Secretariat, 'Mekong IWRM Project Inception Report' (2010) Mekong Integrated Water Resources Management Project <http://mrcmekong.mrcdev.info/assets/Publications/Programme-Documents/2010-0929-Final-Inception-ReportMIWRMP.pdf> accessed 29 September 2016

[12] Mekong River Commission, 'Public Participation in the Context of the MRC' (1999) Publications of the Mekong River Commission <http://www.mrcmekong.org/assets/Publications/policies/Public-Participation-in-

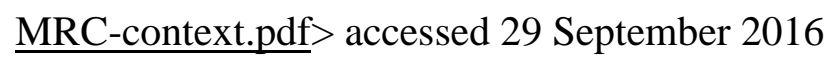


[13] Mekong River Commission, 'Public Participation in the Lower Mekong Basin' (2005) Publications of the Mekong River Commission <http://www.mrcmekong.org/assets/Publications/governance/Public-Participation.pdf $>$ accessed 29 September 2016

[14] Mekong River Commission, 'The Mekong Connection' (2000) <http://www.mrcmekong.org/assets/Publications/leaflet/mekong-connection.pdf> accessed 29 September 2016

[15] Philip Hirsch, Kurt Mørck Jensen with Ben Boer, Naomi Carrard Stephen, Fitz Gerald, Rosemary Lyster, 'National Interest and Trans-boundary Water Governance in the Mekong'

(2006) Australian Mekong Resource Centre at The University of Sydney in collaboration with Danish International Development Assistance <http://sydney.edu.au/mekong/documents/mekwatgov_mainreport.pdf> accessed 29 September 2016

[16] Philipp Magiera, 'Measures for the Adaptation to Climate Change in the Mekong Region' (2013) Deutsche Gesellschaft für Internationale Zusammenarbeit (GIZ) GmbH, MRC-German Development Cooperation <https://www.deutsche-digitalebibliothek.de/binary/C34BIVVO2KCB5SJJS3KCFRTV5554DAJI/full/1.pdf> accessed 02 October 2016.

[17] Schroeder-Wildberg, 'The 1997 International Watercourses ConventionBackground and Negotiations' (2002) Technical University of Berlin Institute for Landscape and Environmental Planning: Working Paper on Management in Environmental Planning 4/2002 < $\underline{\text { http://www.planen-bauen-umwelt.tu- }}$ berlin.de/fileadmin/a0731/uploads/publikationen/workingpapers/wp00402.pdf> accessed 29 September 2016

[18] Sokhem Pech, 'UN Watercourses Convention and Greater Mekong Sub-region' (2011) UNWC's Global Relevance: South and East Asia <http://www.unwatercoursesconvention.org/images/2012/10/Mekong-andUNWC.pdf $>$ accessed 29 September 2016

[19] The Mekong Research Group, “"Attachment 3: The Legal Framework for Mekong Water Governance" to the Report of National Interest and Trans-boundary Water Governance in the Mekong' (2006) Australian Mekong Resource Centre at The 
University of Sydney in collaboration with Danish International Development Assistance $<$ http://sydney.edu.au/mekong/documents/mekwatgov_att3.pdf $>$ accessed 29 September 2016

\section{Official Websites of Relative International Organizations}

\section{ADB:}

[1] ADB-GMS, 'The Core Environment Program' (Official Website of ADB-GMS

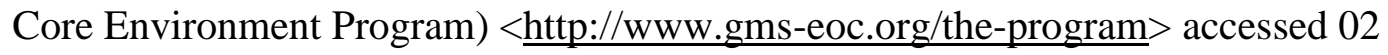
October 2016.

[2] ADB, 'Overview of the Greater Mekong Subregion' (Official Website of Asian Development Bank) <http://www.adb.org/countries/gms/overview> accessed 02 October 2016.

[3] ADB, 'Overview of the Greater Mekong Subregion' (Official Website of the ADB) <http://www.adb.org/countries/gms/overview> accessed 2 October 2016.

\section{ASEAN:}

[1] ASEAN, 'Overview of ASEAN-China Dialogue Relations' (Official Website of the ASEAN), Socio-Cultural Cooperation Paragraph 33

<http://www.asean.org/?static_post=overview-asean-china-dialogue-relations> accessed 2 October 2016.

[2] ASEAN, 'Overview' (Official Website of the ASEAN) < http://asean.org/aseaneconomic-community/asean-mekong-basin-development-cooperationambdc/overview/> accessed 02 October 2016.

[3] ASEAN, 'ASEAN Cooperation on Water Resources Management' (Official Website of the ASEAN) <http://environment.asean.org/asean-working-group-onwater-resources-management-awgwrm/> accessed 02 October 2016.

\section{CCNR:}

[1] CCNR, 'Organisation' (Official Website of the CCNR) <http://www.ccrzkr.org/11000000-en.html> accessed 02 October 2016.

[2] CCNR, 'Current missions of the CCNR' (Official Website of the CCNR) <http://www.ccr-zkr.org/11010400-en.html> accessed 02 October 2016. 


\section{CHR:}

CHR, 'General' (Official Website of the CHR) <http://www.chr-khr.org/en/general> accessed 02 October 2016.

\section{European Commission:}

[1] European Commission, 'Legal Obligations under the EU Bathing Water Directive 2006/7/EC, a summary' (Official Website of the European Commission) <http://ec.europa.eu/environment/water/water-bathing/summary.html> accessed 02 October 2016.

[2] European Commission, 'A review of agricultural measures under the Water Framework Directive' (Official Website of the European Commission) $<$ https://ec.europa.eu/jrc/en/news/review-agricultural-measures-under-waterframework-directive-10235> accessed 02 October 2016.

[3] European Commission, 'Groundwater' (Official Website of the European Commission) <http://ec.europa.eu/environment/water/waterframework/groundwater/resource.htm> accessed 02 October 2016.

\section{GWP and GWPSEA:}

[1] Global Water Partnership, 'About GWP' (Official Website of the Global Water Partnership) <http://www.gwp.org/en/About-GWP/> accessed 29 September 2016. [2] Global Water Partnership, 'China' (Official Website of the Global Water Partnership) http://www.gwp.org/en/gwp-in-action/China/> accessed 02 October 2016.

[3] GWP, '2. Participatory approach' (Official Website of the GWP) <http://www.gwp.org/en/The-Challenge/What-is-IWRM/IWRMPrinciples/Participatory-approach/> accessed 2 October 2016.

[4] Global Water Partnership Southeast Asia, 'About' (Official Website of the Global Water Partnership Southeast Asia <http://www.gwp.org/GWP-South-EastAsia/ABOUT-GWP-SEA/> accessed 29 September 2016.

[5] Global Water Partnership Southeast Asia, 'The Partnership Network' (Official Website of the Global Water Partnership Southeast Asia) <http://www.gwp.org/en/GWP-South-East-Asia/ABOUT-GWP-SEA/ThePartnership-Network/> accessed 29 September 2016. 


\section{ICPR:}

[1] ICPR, 'The Rhine' (Official Website of the ICPR)

<http://www.iksr.org/en/rhine/index.html> accessed 02 October 2016.

[2] ICPR, 'About Us' (Official Website of the ICPR)

<http://www.iksr.org/en/international-cooperation/about-us/index.html> accessed 02

October 2016.

[3] ICPR, 'History' (Official Website of the ICPR)

<http://www.iksr.org/en/international-cooperation/about-us/history/index.html> accessed 02 October 2016.

[4] ICPR, 'Conceiving cooperation' (Official Website of the ICPR)

$<$ http://www.iksr.org/en/international-cooperation/about-us/history/conceivingcooperation/index.html> accessed 02 October 2016.

[5] ICPR, 'Increasing confidence' (Official Website of the ICPR)

$<$ http://www.iksr.org/en/international-cooperation/about-us/history/increasingconfidence/index.html> accessed 02 October 2016.

[6] ICPR, 'The turning point: the Sandoz accident' (Official Website of the ICPR) $<$ http://www.iksr.org/en/international-cooperation/about-us/history/the-turning-pointthe-sandoz-accident/index.html> accessed 02 October 2016.

[7] ICPR, 'Integration and example' (Official Website of the ICPR) $<$ http://www.iksr.org/en/international-cooperation/about-us/history/integration-andexample/index.html> accessed 02 October 2016.

[8] ICPR, 'The Rhine in a European context' (Official Website of the ICPR) $<$ http://www.iksr.org/en/international-cooperation/about-us/history/the-rhine-in-aeuropean-context/index.html> accessed 02 October 2016.

[9] ICPR, 'Success' (Official Website of the ICPR) < http://www.iksr.org/en/international-cooperation/aboutus/challenges/success/index.html> accessed 02 October 2016.

[10] ICPR, 'Challenges' (Official Website of the ICPR) <http://www.iksr.org/en/international-cooperation/about-us/challenges/index.html> accessed 02 October 2016. 
[11] ICPR, 'Convention on the Protection of the Rhine' (Official Website of the ICPR) $<$ http://www.iksr.org/en/international-cooperation/legal-basis/convention/index.html> accessed 02 October 2016.

[12] ICPR, 'European Water Framework Directive' (Official Website of the ICPR) $<$ http://www.iksr.org/en/international-cooperation/legal-basis/european-waterframework-directive/index.html> accessed 02 October 2016.

[13] ICPR, 'Targets and principles of the Water Framework Directive' (Official Website of the ICPR) <http://www.iksr.org/en/international-cooperation/legalbasis/european-water-framework-directive/targets-and-principles/index.html> accessed 02 October 2016.

[14] ICPR, 'Environmental targets' (Official Website of the ICPR) $<$ http://www.iksr.org/en/international-cooperation/legal-basis/european-waterframework-directive/environmental-targets/index.html> accessed 02 October 2016.

[15] ICPR, 'Directive on the Assessment and Management of Flood Risks' (Official Website of the ICPR) <http://www.iksr.org/en/floods-directive/index.html> accessed 26 October 2016

[16] ICPR, 'Public participation', Official Website of the ICPR) <http://www.iksr.org/en/floods-directive/public-participation/index.html> accessed 26 October 2016.

[17] ICPR, 'Organisation' (Official Website of the ICPR) <http://www.iksr.org/en/international-cooperation/about-us/organisation/index.html> accessed 02 October 2016.

[18] ICPR, 'Secretariat' (Official Website of the ICPR) <http://www.iksr.org/en/international-cooperation/about-us/secretariat/index.html> accessed 02 October 2016.

[19] ICPR, 'Conferences of ministers' (Official Website of the ICPR)

<http://www.iksr.org/en/international-cooperation/conferences-ofministers/index.html> accessed 02 October 2016.

[20] ICPR, 'Observers' (Official Website of the ICPR) <http://www.iksr.org/en/international-cooperation/about-us/observers/index.html> accessed 02 October 2016. 
[21] ICPR, 'Targets and principles of the Water Framework Directive' (Official Website of the ICPR) <http://www.iksr.org/en/international-cooperation/legalbasis/european-water-framework-directive/targets-and-principles/index.html> accessed 02 October 2016.

[22] ICPR, 'Uses' (Official Website of the ICPR) <http://www.iksr.org/en/uses/index.html> accessed 02 October 2016.

[23] ICPR, 'Inventory' (Official Website of the ICPR) <http://www.iksr.org/en/waterframework-directive/inventory/index.html> accessed 27 October 2016.

[24] ICPR, 'River basin management plan 2015' (Official Website of the ICPR) $<\mathrm{http}$ //www.iksr.org/en/water-framework-directive/river-basin-management-plan2015/index.html> accessed 27 October 2016.

[25] ICPR, 'Internationally Coordinated Management Plan 2015 for the International River Basin District of the Rhine' (2015) Bewirtschaftungsplan 2015 IFGE Rhein <http://www.iksr.org/fileadmin/user_upload/Dokumente_en/Brochures/CMP_2015__en.pdf> accessed 27 October 2016.

[26] ICPR, 'Rhine 2020 - Program on the sustainable development of the Rhine' (Official Website of the ICPR) <http://www.iksr.org/en/internationalcooperation/rhine-2020/index.html> accessed 02 October 2016.

[27] ICPR, 'Settlements' (Official Website of the ICPR) <http://www.iksr.org/en/uses/settlements/index.html> accessed 02 October 2016. [28] ICPR, 'Leisure' (Official Website of the ICPR) <http://www.iksr.org/en/uses/leisure/index.html> accessed 02 October 2016. [29] ICPR, 'Micro-pollutants of diffuse origin (2010)' (Official Website of the ICPR) $<$ http://www.iksr.org/en/events/2nd-icpr-workshop-on-micro-pollutants-of-diffuseorigin/index.html> accessed 02 October 2016.

[30] ICPR, 'Drinking water' (Official Website of the ICPR) <http://www.iksr.org/en/uses/drinking-water/index.html> accessed 02 October 2016. [31] ICPR, 'Agriculture' (Official Website of the ICPR) <http://www.iksr.org/en/uses/agriculture/index.html> accessed 02 October 2016. 
[32] ICPR, 'Nutrients' (Official Website of the ICPR)

$<$ http://www.iksr.org/en/topics/pollution/nutrients/index.html > accessed 02 October 2016.

[33] ICPR, 'Water protection measures' (Official Website of the ICPR)

$<$ http://www.iksr.org/en/uses/agriculture/water-protection-measures/index.html> accessed 02 October 2016.

[34] ICPR, 'Measures' (Official Website of the ICPR)

<http://www.iksr.org/en/international-cooperation/rhine-2020/measures/index.html> accessed 02 October 2016.

[35] ICPR, 'Floods' (Official Website of the ICPR)

<http://www.iksr.org/en/topics/floods/index.html> accessed 02 October 2016.

[36] ICPR, 'Action Plan on Floods' (Official Website of the ICPR)

<http://www.iksr.org/en/international-cooperation/rhine-2020/action-plan-on-

floods/index.html> accessed 02 October 2016.

[37] ICPR, 'Rhine Atlas 2015' (Official Website of the ICPR)

<http://www.iksr.org/en/documentsarchive/rhine-atlas/index.html > accessed 02

October 2016.

[38] ICPR, 'Directive on the Assessment and Management of Flood Risks', (Official Website of the ICPR) <http://www.iksr.org/en/floods-directive/index.html> accessed 02 October 2016.

[39] ICPR, 'Flood Risk Management Plan 2015' (Official Website of the ICPR) <http://www.iksr.org/en/floods-directive/flood-risk-management-plan/index.html> accessed 02 October 2016.

[40] ICPR, 'Flood warning and forecasting centres' (Official Website of the ICPR) $<$ http://www.iksr.org/en/topics/floods/flood-warning-and-forecastingcentres/index.html> accessed 02 October 2016.

[41] ICPR, 'Low Water' (Official Website of the ICPR) <http://www.iksr.org/en/topics/low-water/index.html> accessed 02 October 2016.

[42] ICPR, 'Climate change in the Rhine catchment' (Official Website of the ICPR) $<$ http://www.iksr.org/en/topics/climate-change-in-the-rhine-catchment/index.html> accessed 29 September 2016. 
[43] ICPR, 'Navigation' (Official Website of the ICPR)

<http://www.iksr.org/en/uses/navigation/index.html> accessed 02 October 2016.

[44] ICPR, 'Nature protection' (Official Website of the ICPR)

$<$ http://www.iksr.org/en/uses/nature-protection/index.html> accessed 02 October 2016.

[45] ICPR, 'Measures aimed at improving the Rhine ecosystem' (Official Website of the ICPR) <http://www.iksr.org/en/uses/nature-protection/measures-aimed-atimproving-the-rhine-ecosystem/index.html> accessed 02 October 2016.

[46] ICPR, 'Hydropower' (Official Website of the ICPR)

<http://www.iksr.org/en/uses/hydropower/index.html> accessed 02 October 2016.

[47] ICPR, 'Hydropeaking' (Official Website of the ICPR)

<http://www.iksr.org/en/uses/hydropower/hydropeaking/index.html> accessed 02

October 2016.

[48] ICPR, 'The Rhine in the triangle of sustainability' (Official Website of the ICPR) $<$ http://www.iksr.org/en/international-cooperation/legalbasis/convention/sustainability/index.html> accessed 02 October 2016.

[49] ICPR, 'Planning of measures' (Official Website of the ICPR)

<http://www.iksr.org/en/international-cooperation/legal-basis/european-water-

framework-directive/planning-of-measures/index.html > accessed 02 October 2016.

[50] ICPR, 'Water Quality’ (Official Website of the ICPR)

<http://www.iksr.org/en/topics/water-quality/index.html> accessed 2 October 2016.

[51] ICPR, 'Surface waters' (Official Website of the ICPR)

$<$ http://www.iksr.org/en/topics/water-quality/surface-waters/index.html> accessed 2

October 2016.

[52] ICPR, 'Groundwater' (Official Website of the ICPR)

<http://www.iksr.org/en/topics/water-quality/groundwater/index.html> accessed 2

October 2016.

[53] ICPR, 'Monitoring of the state' (Official Website of the ICPR)

<http://www.iksr.org/en/topics/water-quality/monitoring-of-the-state/index.html> accessed 2 October 2016. 
[54] ICPR, 'Targets aimed at improving water quality' (Official Website of the ICPR) $<$ http://www.iksr.org/en/topics/water-quality/targets/index.html > accessed 2 October 2016.

[55] ICPR, 'Salmon 2020' (Official Website of the ICPR)

$<$ http://www.iksr.org/en/international-cooperation/rhine-2020/salmon-

2020/index.html> accessed 2 October 2016.

[56] ICPR, '166. und 167. Effectiveness of measures for a successful and sustainable reintroduction of migratory fish in the Rhine watershed' (Official Website of the ICPR) <http://www.iksr.org/en/documentsarchive/technical-reports/reports-andbrochures-individual-presentation/artikel/462/index.html> accessed 2 October 2016.

[57] ICPR, 'Industry' (Official Website of the ICPR)

<http://www.iksr.org/en/uses/industry/index.html> accessed 2 October 2016.

\section{MRC:}

[1] MRC, 'Development Partners \& Partner Organisations' (Official Website of MRC) $<$ http://www.mrcmekong.org/about-mrc/development-partners-and-partnerorganisations/> accessed 02 October 2016.

[2] MRC, 'Basin Planning' (Official Website of the MRC) <http://www.mrcmekong.org/topics/basin-planning/> accessed 02 October 2016.

[3] MRC, 'About MRC' (Official Website of the MRC) <http://www.mrcmekong.org/about-mrc/> accessed 02 October 2016.

[4] MRC, 'Mekong River Commission and China boost water data exchange' (Vientiane, 30 August 2013) <http://www.mrcmekong.org/news-andevents/news/mekong-river-commission-and-china-boost-water-data-exchange/> accessed 29 September 2016

[5] MRC, 'Upstream Partners' (Official Website of the MRC) <http://www.mrcmekong.org/about-mrc/upstream-partners/> accessed 29 September 2016

[6] MRC, 'MRC, China and Myanmar cooperate on shared Mekong resources' (Official Website of the MRC) <http://www.mrcmekong.org/news-andevents/news/mrc-china-and-myanmar-cooperate-on-shared-mekong-resources/> accessed 29 September 2016. 
[7] MRC, 'Development Partners \& Partner Organisations' (Official Website of the MRC) < http://www.mrcmekong.org/about-mrc/development-partners-and-partnerorganisations/> accessed 29 September 2016.

[8] MRC, 'Joint Development Partner Statement, 24 June 2015' (Vientiane, 24 June 2015) <http://www.mrcmekong.org/news-and-events/speeches/joint-developmentpartner-statement-24-june-2015/> accessed 29 September 2016.

[9] MRC, 'Basin Planning' (Official Website of the MRC) <http://www.mrcmekong.org/topics/basin-planning/> accessed 02 October 2016. [10] MRC, 'Mekong Integrated Water Resources Management Project' (Official Website of the MRC) <http://mrcmekong.mrcdev.info/about$\mathrm{mrc} /$ programmes/mekong-integrated-water-resources-management-project/> accessed 02 October 2016.

[11] MRC, 'People' (Official Website of the MRC) <http://mrcmekong.mrcdev.info/topics/people/> accessed 02 October 2016.

[12] MRC, 'Environment Programme' (Official Website of the MRC) $<$ http://mrcmekong.mrcdev.info/about-mrc/programmes/environment-programme/> accessed 02 October 2016.

[13] MRC, 'Agriculture \& Irrigation' (Official Website of the MRC) <http://www.mrcmekong.org/topics/agriculture-and-irrigation/> accessed 02 October 2016.

[14] MRC, 'Redefining MRC's Role in the Agriculture Sector' (Official Website of the MRC) <http://www.mrcmekong.org/about-mrc/programmes/agriculture-andirrigation-programme/redefining-mrc-s-role-in-the-agriculture-sector/> accessed 02 October 2016.

[15] MRC, 'Agriculture and Irrigation Programme', Official website fo the MRC $<$ http://www.mrcmekong.org/about-mrc/completion-of-strategic-cycle-20112015/agriculture-and-irrigation-programme/> accessed 02 October 2016.

[16] MRC, 'Demonstration of Multi-functionality of Paddy Fields' (Official Website of the MRC) <http://www.mrcmekong.org/about-mrc/programmes/agriculture-andirrigation-programme/demonstration-of-multi-functionality-of-paddy-fields/> accessed 02 October 2016. 
[17] MRC, 'Improvement of Irrigation Efficiency' (Official Website of the MRC) <http://www.mrcmekong.org/about-mrc/programmes/agriculture-and-irrigationprogramme/improvement-of-irrigation-efficiency/> accessed 02 October 2016.

[18] MRC, 'Flood \& Drought' (Official Website of the MRC) <http://www.mrcmekong.org/topics/flood-and-drought/> accessed 02 October 2016. [19] MRC, 'River Monitoring' (Official Website of the MRC) <http://www.mrcmekong.org/mrc/river-monitoring/> accessed 02 October 2016. [20] MRC, 'Flood Management \& Mitigation Programme' (Official Website of the MRC) <http://www.mrcmekong.org/about-mrc/programmes/flood-management-andmitigation-programme/> accessed 02 October 2016.

[21] MRC, 'Information \& Knowledge Management Programme' (Official Website of the MRC) <http://www.mrcmekong.org/about-mrc/programmes/information-andknowledge-management-programme/> accessed 02 October 2016.

[22] MRC, 'MRC Data and Information Services Portal' (Official Website of the MRC) <http://portal.mrcmekong.org/index> accessed 02 October 2016.

[23] MRC, 'Climate Change' (Official Website of the MRC) <http://www.mrcmekong.org/topics/climate-change/> accessed 02 October 2016. [24] MRC, 'Climate Change and Adaptation Initiative' (Official Website of the MRC) <http://www.mrcmekong.org/about-mrc/programmes/climate-change-and-adaptationinitiative/> accessed 02 October 2016.

[25] MRC, 'River Transport' (Official Website of the MRC) <http://mrcmekong.mrcdev.info/topics/river-transport/> accessed 02 October 2016. [26] MRC, 'Navigation Programme' (Official Website of the MRC) <http://www.mrcmekong.org/about-mrc/programmes/navigation-programme/> accessed 02 October 2016.

[27] MRC, 'Cambodia and Viet Nam formally open-up cross-border river trade on the Mekong' (Vientiane 17 December 2009) <http://mrcmekong.mrcdev.info/news-andevents/news/cambodia-and-viet-nam-formally-open-up-cross-border-river-trade-onthe-mekong/> accessed 02 October 2016. 
[28] MRC, 'Natrual Resources' (Official Website of the MRC)

$<$ http://www.mrcmekong.org/mekong-basin/natural-resources/> accessed 02 October 2016.

[29] MRC, 'Environmental Health' (Official Website of the MRC)

$<$ http://www.mrcmekong.org/topics/environmental-health/> accessed 02 October 2016.

[30] MRC, 'Procedures for Water Quality' (Official Website of the MRC)

<http://www.mrcmekong.org/about-mrc/mandate/procedures-for-water-quality/> accessed 02 October 2016.

[31] MRC, 'Transboundary EIA' (Official Website of the MRC)

$<$ http://www.mrcmekong.org/about-mrc/programmes/environment-

programme/transboundary-eia/> accessed 02 October 2016.

[32] MRC, 'Sustainable Hydropower' (Official Website of the MRC)

$<$ http://www.mrcmekong.org/topics/sustainable-hydropower/> accessed 02 October 2016.

[33] MRC, 'Initiative on Sustainable Hydropower' (Official Website of the MRC) $<$ http://www.mrcmekong.org/about-mrc/programmes/initiative-on-sustainablehydropower/> accessed 02 October 2016.

[34] MRC, 'Fisheries' (Official Website of the MRC) <http://www.mrcmekong.org/topics/fisheries/> accessed 02 October 2016.

[35] MRC, 'Fisheries Programme' (Official Website of the MRC) <http://mrcmekong.mrcdev.info/about-mrc/programmes/fisheries-programme/> accessed 02 October 2016.

[36] MRC, 'FAQ on Procedures for Water Quality' (Official Website of the MRC) $<$ http://www.mrcmekong.org/about-mrc/mandate/faq-on-procedures-for-waterquality/> accessed 27 October 2016.

[37] MRC, 'MRC Council concludes a future direction for the organization' (Phnom Penh, 13 January 2016) <http://www.mrcmekong.org/news-and-events/news/mrccouncil-concludes-a-future-direction-for-the-organisation/> accessed 2 October 2016. [38] MRC, 'Panel of Experts on the Basin Development Plan Phase 2' (Vientiane, 17 August 2010-8 October 2010) <http://www.mrcmekong.org/news-and- 
events/consultations/panel-of-experts-on-the-basin-development-plan-phase-2/> accessed 2 October 2016.

[39] MRC, 'Xayaburi Hydropower Project Prior Consultation Process' (Vientiane, 15 December 2010-22 April 2011) <http://www.mrcmekong.org/news-andevents/consultations/xayaburi-hydropower-project-prior-consultation-process/> accessed 2 October 2016.

[40] MRC, 'Strategic Environmental Assessment of Mainstream Dams' (Official Website of the MRC) <http://www.mrcmekong.org/about-mrc/completion-ofstrategic-cycle-2011-2015/initiative-on-sustainable-hydropower/strategicenvironmental-assessment-of-mainstream-dams/> accessed 2 October 2016. [41] MRC, 'Don Sahong Hydropower Project' (Vientiane, 15 October 2014-31 January 2015) <http://www.mrcmekong.org/news-and-events/consultations/donsahong-hydropower-project/> accessed 29 September 2016.

\section{Other}

[1] Richard Paisley, 'Mekong' (International Waters Governance)

<http://www.internationalwatersgovernance.com/mekong.html $>$ accessed 29

September 2016

[2] The Water Page, 'Mekong River Commission: A Brief Guide'

<http://www.thewaterpage.com/mrc notes.htm> accessed 29 September 2016

[3] Oxford English Dictionary, 'Regime'

<http://www.oed.com/view/Entry/161266?redirectedFrom=regime\#eid > accessed 02 October 2016

[4] International Water Governance, 'Mekong'

<http://www.internationalwatersgovernance.com/mekong.html> accessed 29

September 2016

[5] Chinese Ministry of Foreign Affairs, 'Wang Yi elaborated on the five priority areass and three cooperation pillars of the Lancang-Mekong Cooperation Mechanism' Chinese Ministry of Foreign Affairs (Beijing, 12 November 2015) <http://www.fmprc.gov.cn/web/wjdt_674879/wjbxw_674885/t1314376.shtml> accessed 29 September 2016. 


\section{List of Acronyms}

ADB

AIIB

AMBDC

ASEAN

AWGWRM

BDP

CAP

CBD

CCAI

CCNR

CEO

CEP

CHR

DCG

EC

ECAFE

ECE

EIA

ENCs

ESCAP
The Asian Development Bank

The Asian Infrastructure Investment

Bank

The ASEAN-Mekong Basin

Development Cooperation

The Association of Southeast Asian

Nations

The ASEAN Working Group on the

Water Resource Management

The Basin Development Plan

The EU Common Agriculture Policy

The Convention on Biological Diversity

The Climate Change and Adaptation

Initiative

The Central Commission for the

Navigation on the Rhine

Chief Executive Officer

The Core Environment Program

International Commission for the

Hydrology of the Rhine Basin

The Donor Consultative Group

European Commission

The United Nation's Economic

Commission for Asia and the Far East

The Economic Commission for Europe

Environmental Impact Assessment

The Electronic Navigation Charts

The United Nations' Economic and 
Social Commission for Asia and the

Pacific

EU

European Union

FMM

The Flood Management and Mitigation

FMMP

The Flood Management and Mitigation

Programme

GDP

Gross Domestic Product

GMS

The Great Mekong Sub-region

GWP

The Global Water Partnership

GWP-SEA

The Global Water Partnership Southeast-

Asia

ICJ

The International Court of Justice

ICPR

The International Commission for the

Protection of the Rhine

IKMP

The Information and Knowledge

Management Programme

ILA

The International Law Association

IMC

The 1978 Interim Mekong Committee

ISH

The Initiative on Sustainable Hydropower

IUCN

The International Union for Conservation of Nature

IWRM

The Integrated Water Resources

Management

$\mathrm{JC}$

The Joint Committee of the Mekong

River Commission

LMRB

Lower Mekong River Basin

LMRBS

Lower Mekong River Basin States

MRC

Mekong River Commission 
MRCS

MWG

NGO

NMC

OECD

OSPAR

PDIES

PDR

PNPCA

SIDA

SEA

TbEIA

UN

UNDP

UNECE

UNEP

UNESCAP

UNESCO
The Mekong River Commission

Secretariat

The Mekong Working Group

Non-governmental Organization

The National Mekong Committee

The Organization for Economic Co-

operation and Development

The Convention for the Protection of the

Marine Environment of the North East

Atlantic

The Procedures for Data and Information

Exchange and Sharing

Democratic Republican Party

Procedures for Notification, Prior

Consultation and Agreement

The Swedish International Development

Cooperation Agency

South East Asia

Transboundary Environmental Impact

Assessment

United Nations

United Nations Development Programme

United Nations Economic Commission

for Europe

United Nations Environment Programme

United Nations Economic and Social

Commission for Asia and the Pacific

United Nations Educational, Scientific

and Cultural Organization 
UNGA

UNWC:

US

WFD

WUP

WWF
General Assembly of the United Nations

Convention on the Law of the Non-

navigational Uses of International

Watercourses

United States

The European Water Framework

Directive

The Water Utilization Programme

The World Wide Fund for Nature 